\title{
WestVirginiaUniversity
}

THE RESEARCH REPOSITORY @ WVU

Graduate Theses, Dissertations, and Problem Reports

2012

\section{Evaluation of methods for measuring aggregate specific gravity}

\author{
Rajasekhar Bikya \\ West Virginia University
}

Follow this and additional works at: https://researchrepository.wvu.edu/etd

\section{Recommended Citation}

Bikya, Rajasekhar, "Evaluation of methods for measuring aggregate specific gravity" (2012). Graduate Theses, Dissertations, and Problem Reports. 581.

https://researchrepository.wvu.edu/etd/581

This Thesis is protected by copyright and/or related rights. It has been brought to you by the The Research Repository @ WVU with permission from the rights-holder(s). You are free to use this Thesis in any way that is permitted by the copyright and related rights legislation that applies to your use. For other uses you must obtain permission from the rights-holder(s) directly, unless additional rights are indicated by a Creative Commons license in the record and/ or on the work itself. This Thesis has been accepted for inclusion in WVU Graduate Theses, Dissertations, and Problem Reports collection by an authorized administrator of The Research Repository @ WVU. For more information, please contact researchrepository@mail.wvu.edu. 


\title{
EVALUATION OF METHODS FOR MEASURING AGGREGATE SPECIFIC GRAVITY
}

\author{
Rajasekhar Bikya
}

Thesis submitted to the

Benjamin M. Statler College of Engineering and Mineral Resources

at West Virginia University

in partial fulfillment of the requirements

for the degree of

Master of Science

in

Civil Engineering

Dr. John P. Zaniewski, Chair

Dr. Radhey Sharma, Co-Chair

Dr. Avinash Unnikrishnan

Department of Civil and Environmental Engineering

Morgantown, West Virginia

2012

Keywords: Bulk specific gravity, Apparent specific gravity, Absorption, Aggregates, Limestone, Slag 


\section{ABSTRACT \\ EVALUATION OF METHODS FOR MEASURING AGGREGATE SPECIFIC GRAVITY}

\section{Rajasekhar Bikya}

The current American Association of State Highway and Transportation Officials (AASHTO) procedures for determining the aggregate specific gravities and absorption values are time consuming and hence are not appropriate for quality control processes. These methods are not repeatable too which is another issue with the standard test methods. The standard AASHTO method for fine aggregates has problems with angular and absorptive materials. Due to this problem several agencies have developed alternative methods. Correct measurement of the specific gravity and absorption play a crucial role in the design of hot mix asphalt (HMA) mixtures. Improper measurements can lead to poor asphalt being accepted for a certain job and on the other hand good quality asphalt may be rejected. The pavement life is at great risk if poor quality asphalt is accepted. And there can be a lot of cost concerns if good quality asphalt is being rejected.

This research evaluated the specific gravity test methods for fine aggregates. The focus of the research is to find a test method that is suitable for all types of fine aggregates. There were 9 different methods used to determine the fine aggregate specific gravities apart from the standard AASHTO method. All the selected methods are the modifications made by other agencies in order to improve the test accuracy. The comparison between the different methods to the AASHTO method was done using the student $t$ distribution test. 


\section{ACKNOWLEDGEMENTS}

I would like to express my sincere gratitude to Dr. John P. Zaniewski, my advisor, who helped me to choose this topic. I thank him for his patience, guidance and immeasurable support at all stages during this research without which this research would not have been possible.

I would also like to thank Dr. Radhey Sharma and Dr. Avinash Unnikrishnan, members of my thesis committee, for their time and guidance. I thank Dr. Radhey Sharma for being the co advisor for my research study and also for his support right from the date I joined West Virginia University.

Special thanks to J.F. Allen Company for providing the required materials for the research work. A very special thanks to Mr. Chad Miller for helping us get the aggregates from J.F. Allen Company. I would also like to thank the people, who helped me in the laboratory, Mr. John Elias Crane, Yu Yan and Hadi Rashidi. Sincere thanks to Anshul Soanpet for being the source of my strength, support and love throughout the two years at Morgantown.

My most special thanks go to my parents, Mr. Venkat Ram and Mrs. Suvarna for their love and support in every phase of my life. 


\section{TABLE OF CONTENTS}

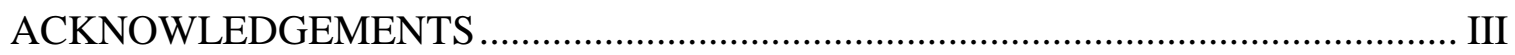

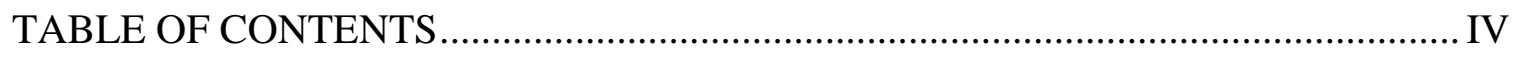

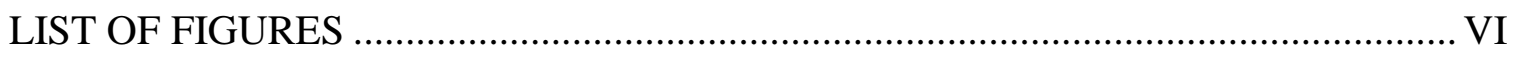

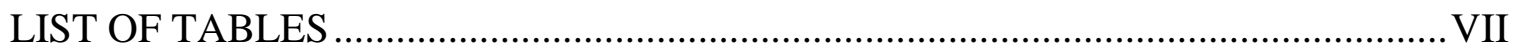

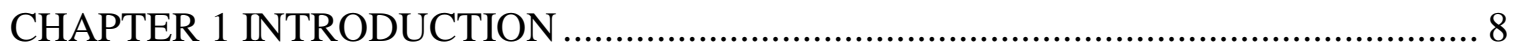

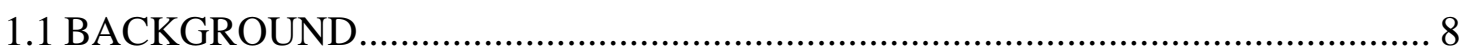

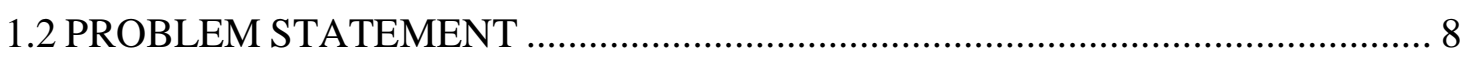

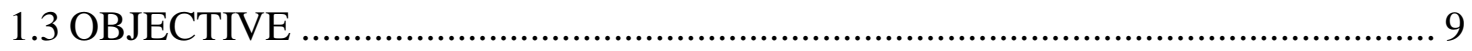

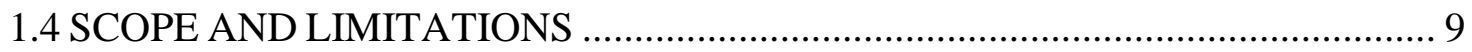

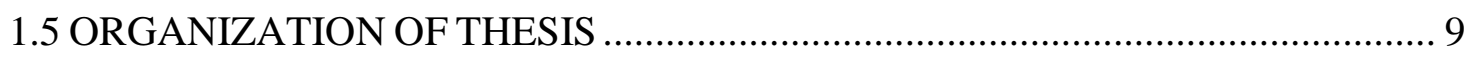

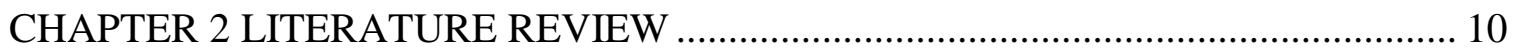

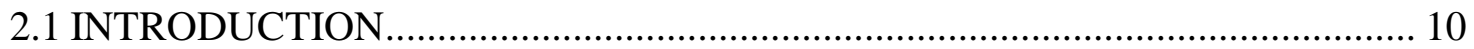

2.2 SPECIFIC GRAVITY OF AGGREGATES ………….................................... 10

2.3 APPLICATION AND SIGNIFICANCE OF SPECIFIC GRAVITY OF

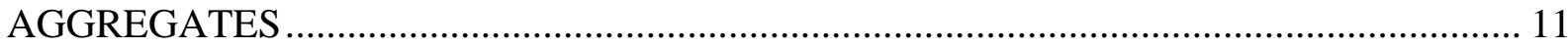

2.4 CURRENT METHODS AND RELATED PROBLEMS ...................................... 13

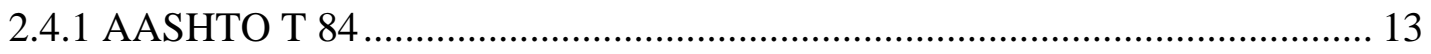

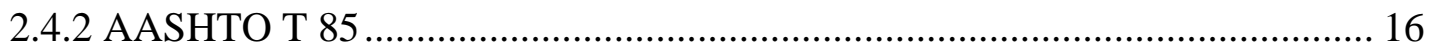

2.5 ALTERNATE TEST METHODS ................................................................ 17

2.5.1 Modifications to Available Test Methods......................................................... 17

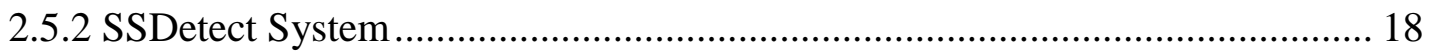

2.5.3 AggPlus System using CoreLok Device .......................................................... 20

2.5.4 Arizona DOT Method ............................................................................... 23

2.5.5 Wisconsin Method ................................................................................... 23

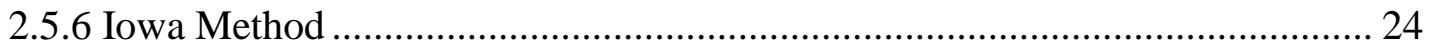

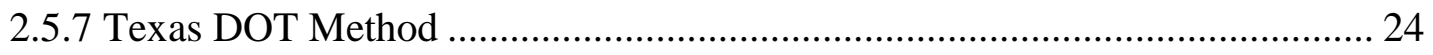

2.5.8 California Method .................................................................................. 25

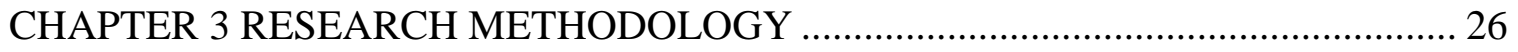




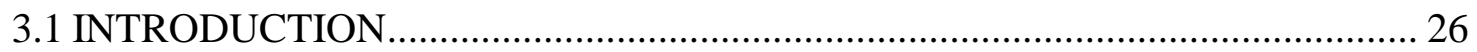

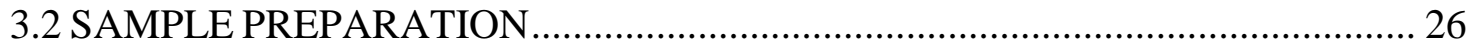

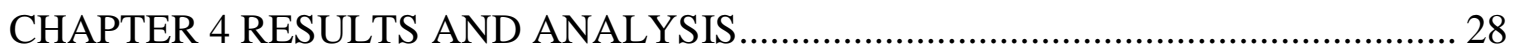

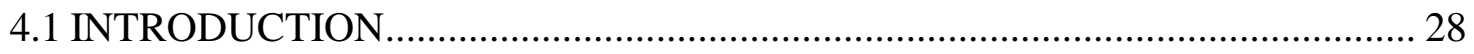

4.2 LIMESTONE FINE AGGREGATES ……………......................................... 28

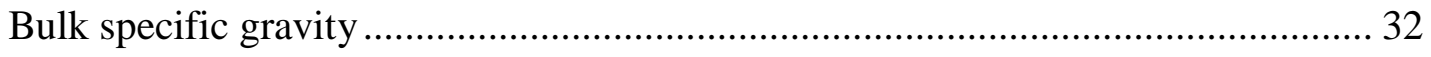

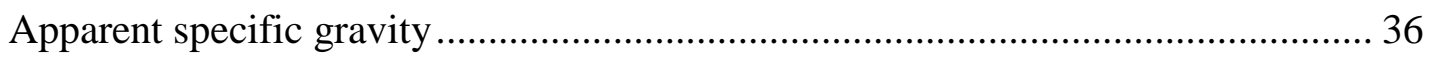

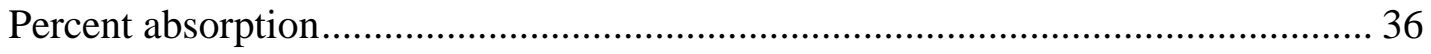

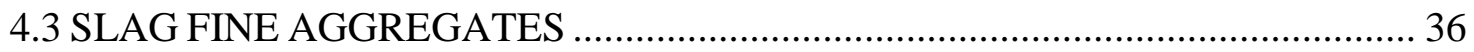

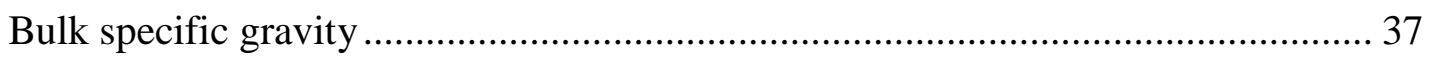

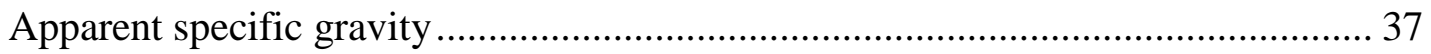

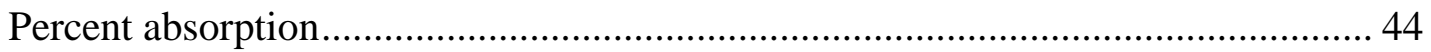

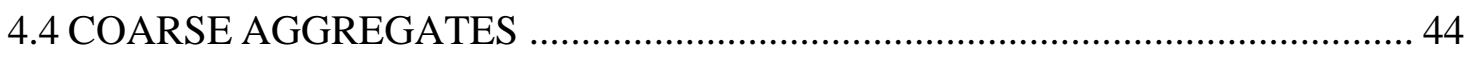

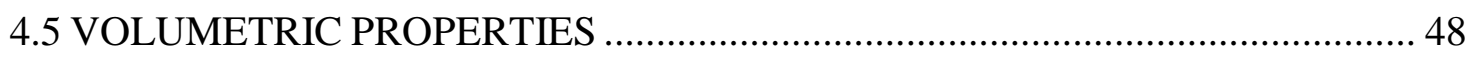

CHAPTER 5 CONCLUSIONS AND RECOMMENDATIONS ...................................... 51

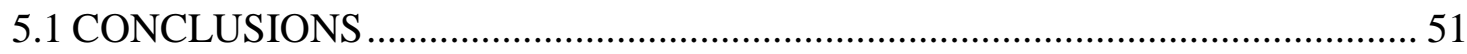

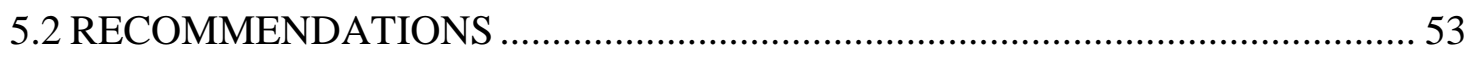

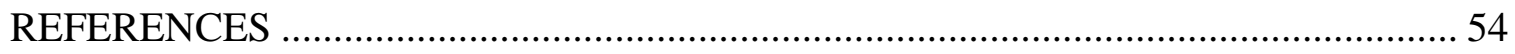

APPENDIX 1 DATA

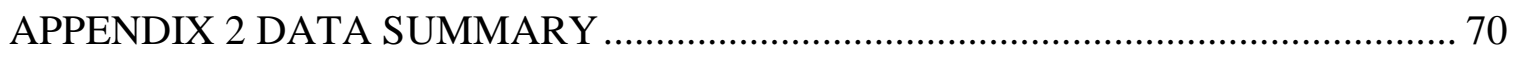

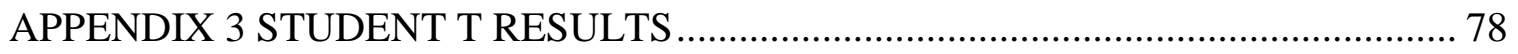




\section{LIST OF FIGURES}

Figure 1 Automatic Volumetric Mixer and Infrared Units (Barnstead/Thermolyne)................... 19

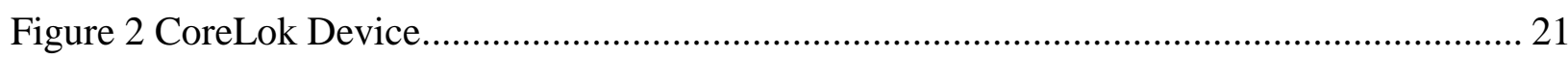

Figure 3 Comparison of $\mathrm{G}_{\mathrm{sb}}$ values from different tests for limestone fine aggregates................ 29

Figure 4 Comparison of $\mathrm{G}_{\mathrm{sa}}$ values from different tests for limestone fine aggregates................. 30

Figure 5 Comparison of percent absorption values from different tests for limestone fine

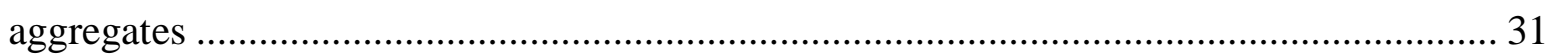

Figure 6 Comparison of $\mathrm{G}_{\mathrm{sb}}$ values from different tests for slag fine aggregates......................... 38

Figure 7 Comparison of $\mathrm{G}_{\mathrm{sa}}$ values from different tests for slag fine aggregates......................... 39

Figure 8 Comparison of percent absorption values from different tests for slag fine aggregates 40

Figure 9 Comparison of $\mathrm{G}_{\mathrm{sb}}$ values for coarse aggregates ......................................................... 45

Figure 10 Comparison of $\mathrm{G}_{\mathrm{sa}}$ values for coarse aggregates ..................................................... 46

Figure 11 Comparison of percent absorption values for coarse aggregates .................................. 47

Figure 12 VMA values using specific gravity values from different methods .............................50

Figure 13 Line of equality comparison of VMA from different test methods.............................. 50 


\section{LIST OF TABLES}

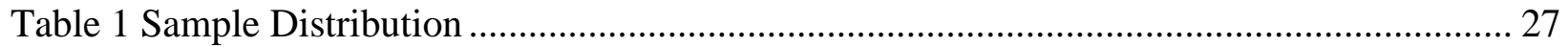

Table 2 Student $\mathrm{p}$ values for bulk specific gravity results for limestone fine aggregates ........... 33

Table 3 Student $\mathrm{p}$ values for apparent specific gravity results for limestone fine aggregates...... 34

Table 4 Student $\mathrm{p}$ values for percent absorption results for limestone fine aggregates............... 35

Table 5 Student $\mathrm{p}$ values for bulk specific gravity results for slag fine aggregates.................... 41

Table 6 Student $\mathrm{p}$ values for apparent specific gravity results for slag fine aggregates .............. 42

Table 7 Student $\mathrm{p}$ values for percent absorption results for slag fine aggregates...................... 43

Table 8 Coarse aggregate p-values from Student $\mathrm{t}$ analysis for CoreLok versus T 85............... 48

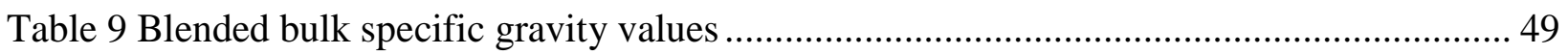




\section{Chapter 1 INTRODUCTION}

\subsection{BACKGROUND}

The specific gravity and absorption of fine and coarse materials need to be measured with high degree of accuracy since they are essential for the development of satisfactory mix designs for the production of the hot mix asphalt (HMA). The American Association of State Highway and Transportation Officials (AASHTO) provide standards for testing of materials. The AASHTO test methods have been in use since their introduction in order to measure the specific gravity and absorption values of aggregate materials. The current tests used for determining the specific gravity and absorption of aggregates are AASHTO T 85 and AASHTO T 84 for coarse and fine aggregates respectively. The corresponding ASTM methods are C 127 and C 128 respectively. The dividing sieve for separating coarse and fine aggregates is the $4.75 \mathrm{~mm}$ sieve.

As demonstrated in the literature survey, there have been multiple attempts to refine or replace the AASHTO method, especially for fine aggregates. There are two issues with the AASHTO methods. Both methods require preparing the samples by first drying, and then saturating for an extended period of time. This inhibits laboratory productivity. The second problem is with determining the saturated surface dry (SSD) moisture state of the aggregates. For coarse aggregates SSD is determined by visual examination, which is subjective. For fine aggregates common method for determining the SSD state is based on a cone-slump test. In essence this method relies on the surface tension of moisture on the face of the aggregate to maintain the cone shape when the mold is removed. Once the moisture is reduced so the surface of the aggregate is dry, the aggregate should slump when the mold is removed. The moisture content at which the aggregate slumps when the mold is removed indicates the aggregate are in a SSD condition state. The problem is angular and textured aggregates can retain the shape of the mold even when the moisture is at the SSD condition. Limestone and slag aggregates are susceptible to this problem.

\subsection{PROBLEM STATEMENT}

Due to the issues with the time required for the aggregate specific gravity test and concerns with determining the SSD state, especially of fine aggregates, multiple alternative test methods have been developed both commercially and by state highway agencies. The West 
Virginia Division of Highways, WVDOH, relies on the AASHTO methods. However, there is a concern that the AASHTO methods may not yield reliable results for many slag and limestone aggregates. Hence, there is interest in determining if the alternative methods may provide more timely and accurate results than the current methods.

\subsection{OBJECTIVE}

The objective of this thesis is to evaluate different methods for measuring the aggregate specific gravities for slag and limestone. The results obtained from the alternative methods are statistically compared with results from the standard AASHTO test methods using the Student $t$ distribution test.

\subsection{SCOPE AND LIMITATIONS}

The specific gravity of coarse aggregates was evaluated using AASHTO T 85 and the CoreLok-AggPlus method. The SSDetect device was not available for this research. No attempts have been made to see if the methods adopted by other states can be helpful to find results similar to those of the standard AASHTO methods.

There were 9 different methods tested other than the standard test method for fine aggregates. The CoreLok-AggPlus device was used in case of the coarse aggregate testing.

\subsection{ORGANIZATION OF THESIS}

This thesis consists of five chapters. Chapter 1 is the introduction to the thesis. Chapter 2 contains the literature review which shows the previous work on alternative methods to measure specific gravity and absorption of aggregates. Chapter 3 describes the research methodology. Chapter 4 presents the results and statistical analysis. Finally, the conclusions and few recommendations are presented in Chapter 5. Appendix A and B present the CoreLok/AggPlus procedures to determine the specific gravity and absorption values of the fine and coarse aggregates respectively. 


\section{Chapter 2 LITERATURE REVIEW}

\subsection{INTRODUCTION}

The literature review starts with a summary of the definitions of the specific gravity of aggregates. Then the equations used for volumetric analysis of asphalt concrete are presented. These equations are used in the analysis of the research data to demonstrate the effect of variance in aggregate specific gravity affect the analysis of asphalt concrete. A summary of the AASHTO and ASTM standards is presented including the alternative methods allowed within the standard test methods. The Arizona, Wisconsin, Texas and California state highway agency methods for fine aggregate specific gravity methods are summarized. Finally research efforts on two commercially available devices are summarized.

\subsection{SPECIFIC GRAVITY OF AGGREGATES}

Specific gravity of an aggregate has several definitions to account for the treatment of the surface voids of the aggregate. Based on the type of void being considered the specific gravity is defined into bulk, apparent and effective specific gravities of aggregates.

Apparent Specific Gravity $\left(\mathrm{G}_{\mathrm{sa}}\right)$ is the ratio of the mass in air of a unit volume of nonpermeable portion of aggregate, not considering the permeable voids in the aggregate to the mass in air of an equal volume of gas-free distilled water at a specific temperature. $\mathrm{G}_{\mathrm{sa}}$ is calculated as:

$\mathrm{G}_{\mathrm{sa}}=\frac{\mathrm{A}}{\mathrm{A}-\mathrm{C}}$

where

$$
\begin{aligned}
& A=\text { oven dry mass of aggregate } \\
& C=\text { mass of aggregate in water }
\end{aligned}
$$

Bulk Specific Gravity $\left(\mathrm{G}_{\mathrm{sb}}\right)$ is the ratio of the mass in air of a unit volume of aggregate to the mass of an equal volume of gas-free distilled water at a specific temperature. The surface voids of the aggregate are included with the volume of the aggregate. $G_{\mathrm{sb}}$ is calculated as:

$$
\mathrm{G}_{\mathrm{sb}}=\frac{\mathrm{A}}{\mathrm{B}-\mathrm{C}}
$$

$$
\text { where } \quad \mathrm{A}=\text { oven dry mass of aggregate }
$$




$$
\begin{aligned}
& \mathrm{B}=\mathrm{SSD} \text { mass of aggregate } \\
& \mathrm{C}=\text { mass of aggregate in water }
\end{aligned}
$$

Absorption is the moisture content of the aggregate in the SSD condition, computed as:

$$
\begin{aligned}
& \% \text { Absorption }=\frac{\mathrm{B}-\mathrm{A}}{\mathrm{A}} \times 100 \\
& \text { where } \quad \begin{aligned}
\mathrm{A} & =\text { oven dry mass of aggregate } \\
\mathrm{B} & =\mathrm{SSD} \text { mass of aggregate }
\end{aligned}
\end{aligned}
$$

The volume of the surface voids is determined by measuring the mass of the aggregate when the surface voids are filled with water and the remaining surface if dry, the saturated surface dry (SSD) condition.

The equations for fine aggregates are functionally the same as the coarse aggregate equations with an adjustment for the fact that the mass of the aggregate in water is measured in a calibrated volumetric vessel. This requires an adjustment to the $\mathrm{C}$ term in the above equations.

\subsection{APPLICATION AND SIGNIFICANCE OF SPECIFIC GRAVITY OF AGGREGATES}

The bulk specific gravity of fine and coarse aggregate materials is used in the mix design of HMA. For HMA mix designs the bulk specific gravity is critical information for the design and production of HMA. The bulk specific gravity value is used in the calculation of voids in mineral aggregate (VMA) and effective binder content $\left(\mathrm{P}_{\mathrm{be}}\right)$. The VMA and $\mathrm{P}_{\mathrm{be}}$ are then used to calculate the voids filled with asphalt (VFA) and the fines to asphalt ratio (F/A) (West et al. 2008). The following are the equations used in calculation of these parameters:

$$
\begin{aligned}
& \mathrm{VTM}=100\left(1-\frac{\mathrm{G}_{\mathrm{mb}}}{\mathrm{G}_{\mathrm{mm}}}\right) \\
& \mathrm{VMA}=\left(100-\frac{\mathrm{G}_{\mathrm{mb}}\left(1-\mathrm{P}_{\mathrm{b}}\right)}{\mathrm{G}_{\mathrm{sb}}} \times 100\right)
\end{aligned}
$$




$$
\begin{aligned}
& \mathrm{VFA}=100\left(\frac{\mathrm{VMA}-\mathrm{VTM}}{\mathrm{VMA}}\right) \\
& \mathrm{P}_{\mathrm{s}}=100-\mathrm{P}_{\mathrm{b}} \\
& P_{b a}=100\left(\frac{G_{s e}-G_{s b}}{G_{s e} \times G_{s b}}\right) \times G_{b} \\
& \mathrm{G}_{\mathrm{se}}=\frac{100-\mathrm{P}_{\mathrm{b}}}{\frac{100}{\mathrm{G}_{\mathrm{mm}}}-\frac{\mathrm{P}_{\mathrm{b}}}{\mathrm{G}_{\mathrm{b}}}} \\
& \mathrm{P}_{\mathrm{be}}=\mathrm{P}_{\mathrm{b}}-\frac{\mathrm{P}_{\mathrm{ba}}}{100} \times \mathrm{P}_{\mathrm{s}} \\
& \frac{\mathrm{F}}{\mathrm{A}}=\frac{\mathrm{P}_{200}}{\mathrm{P}_{\mathrm{b}}} \quad\{\text { For Marshall Mixes }\} \\
& \frac{\mathrm{F}}{\mathrm{A}}=\frac{\mathrm{P}_{200}}{\mathrm{P}_{\mathrm{be}}} \quad\{\text { For Superpave Mixes }\} \\
& \text { where: } \\
& \mathrm{VTM}=\text { Voids in total } \operatorname{mix}(\%) \\
& \mathrm{VMA}=\text { Voids in the mineral aggregate }(\%) \\
& \mathrm{VFA}=\text { Voids filled with asphalt }(\%) \\
& \mathrm{G}_{\mathrm{sb}}=\text { Bulk specific gravity of aggregate } \\
& \mathrm{G}_{\mathrm{mb}}=\text { Bulk specific gravity of compacted mixture } \\
& \mathrm{F} / \mathrm{A}=\text { Fines to asphalt ratio } \\
& P_{200}=\text { Percentage of aggregate passing the } \# 200(0.075 \mathrm{~mm}) \text { sieve } \\
& \mathrm{P}_{\mathrm{b}}=\text { Percent binder } \\
& \mathrm{P}_{\mathrm{be}}=\text { Effective percent binder }
\end{aligned}
$$


$\mathrm{P}_{\mathrm{ba}}=$ Percent binder absorbed

$\mathrm{P}_{\mathrm{s}}=$ Aggregate content, percent by total mass of mixture

$\mathrm{G}_{\mathrm{se}}=$ Effective specific gravity of aggregate

In HMA mix designs VMA, VFA and F/A are the parameters used as specification criteria to ensure that the mixture has volumetric properties required for the desired performance of the mix. Therefore an error in determining the specific gravity of aggregate will result in an error in the mix design volumetric calculations. During mix design, errors in $\mathrm{G}_{\mathrm{sb}}$ can result in mixes that are either too lean or too rich in asphalt cement. Lean mixes are prone to rapid weathering, raveling and premature fatigue failure. Rich mixes are prone to rutting, shoving and corrugations. During production of asphalt concrete, errors in $\mathrm{G}_{\mathrm{sb}}$ can lead to rejecting acceptable mixes or accepting improper mixes.

\subsection{CURRENT METHODS AND RELATED PROBLEMS}

The current standard methods used to find the specific gravity and absorption values of aggregates are the AASHTO T84 and ASTM C128 for fine aggregate samples and AASHTO T85 and ASTM C127 for coarse aggregate samples.

\subsubsection{AASHTO T 84}

AASHTO T 84 and ASTM C 128 are used to determine the specific gravity and absorption values of fine aggregates, material passing the No. $4(4.75 \mathrm{~mm})$ sieve. These test methods are similar; the AASHTO T 84 method is reviewed since it is used by the WVDOH. Before performing the test the pycnometer is calibrated by measuring the mass of the pycnometer filled with water at the specified temperature.

The sample is thoroughly mixed and reduced to sample size in accordance with AASHTO T 248. The sample size for this test should be approximately $1 \mathrm{~kg}$. The test samples are dried to a constant weight in an oven at $230 \pm 9^{\circ} \mathrm{F}\left(110 \pm 5^{\circ} \mathrm{C}\right)$ and then cooled to room temperature, approximately 1 to 3 hours. The sample is then soaked in water for the required time based on the test method, 15 to 19 hours for AASHTO T 84. In order to decrease the time to achieve the SSD state, AASHTO allows the sand to be soaked in at least $6 \%$ moisture content for 
the prescribed period. The saturated sample is then spread on a flat, nonabsorbent surface and stirred occasionally to assist in homogeneous drying. A current of warm air may be used to assist drying procedures but care should be taken to avoid loss of fine particles.

\subsubsection{Standard Cone Method}

The cone method is used to determine the SSD condition of the sand. The cone is placed on a smooth surface with the larger diameter facing down. The cone is filled until its overflowing and tamped with 25 light drops of tamper, each drop starting at 0.2 inch above the top of the sample. The mold is carefully lifted vertically. The process is repeated until the aggregate slumps. $500 \pm 10$ grams of the SSD aggregate is weighed and used as the sample for determining the $\mathrm{G}_{\mathrm{sb}}$.

The SSD sand is introduced into the pycnometer filled with some water. The pycnometer is then filled with water to $90 \%$ of pycnometer capacity. Manually roll and agitate the pycnometer to eliminate all entrapped air. The pycnometer is brought to its calibrated capacity by adding water up to the calibrated level. A few drops of isopropyl alcohol may be added to disperse the foam. The total mass of the sample plus water plus pycnometer is recorded to the nearest 0.1 grams. The sample is then dried in an oven regulated at $230 \pm 9^{\circ} \mathrm{F}\left(110 \pm 5^{\circ} \mathrm{C}\right)$ and the dry mass is determined. The mass and volume information are used to calculate the specific gravity and absorption.

The cone method is based on the assumption that moist fine aggregate do not slump due to the presence of moisture while performing the test. However, Sholar et al. (2005) has shown the moisture content at slump does not depend just on the moisture content but also on angularity and texture. The percentage of material passing the No. 200 sieve also influences the slump of fine aggregates (Lee et al. 1990). This shows that the standard method does not work well with aggregates having high angularity, texture and dust content. Hence the use of standard method in these cases leads to an inaccurate determination of the SSD state of aggregates which in turn leads to inaccurate determination of the specific gravity and absorption values.

The test method cannot be completed in a work-day due to the soaking time for the aggregates. Hence, the method is inefficient for quality control purposes. 
Due to issues with determining the SSD moisture state of the aggregates, alternative methods have been developed. Three alternative (provisional) methods are included in AASHTO T 84. The methods are described below.

\subsubsection{Provisional Cone Test}

The difference between the provisional cone and the AASHTO T 84 tests is the tamping method. In the provisional cone test the cone mold is filled and only 10 drops of the tamper are made. The mold is again filled with fine aggregate and 10 drops of tamper are again made. Material is added two more times using three and two drops of tamper respectively. Following the tamping process the mold is removed and the slump observed.

\subsubsection{Provisional Surface Test (AASHTO T 84)}

In this method approximately 100 grams of the material being tested is patted down with hand on a flat, dry, clean, dark, or dull, nonabsorbent surface such as a sheet of rubber, a worn oxidized, galvanized, or steel surface, or a black-painted metal surface. The fine aggregate is removed after one to three seconds. If noticeable moisture is visible on the test surface for more than one to two seconds, then the surface moisture is considered to be present. The aggregates are further dried until no considerable amount of moisture is visible.

\subsubsection{Hard Paper Method}

In this method hard-finished paper towels are used to surface dry the fine aggregate samples. The sample is in the SSD state when the paper towel does not pick up moisture from the sample.

\subsubsection{Informational Note}

The appendix of AASHTO T84 contains an informational note that minus No. 200 can affect the results of the specific gravity test. The difference in specific gravity between washed and unwashed samples is less than 0.03 when the amount of minus No. 200 material is less than four percent and may be as great as 0.13 when the amount of minus No. 200 material is greater than eight percent. There is no recommendation in the method about how this information should be implemented. Section 7 Preparation of Test Specimen is silent on the issue of washing the sample, implying the sample should not be washed. 


\subsubsection{AASHTO T 85}

The determination of coarse aggregate $\mathrm{G}_{\mathrm{sb}}$ starts with mixing the sample thoroughly and reducing it to the required size in accordance with AASHTO T 248. It is then dry sieved through a No. $4(4.75 \mathrm{~mm})$ sieve and any material passing the sieve is discarded. The retained sample is washed over the No. 4 sieve and dried to constant weight in an oven regulated at $230 \pm 9^{\circ} \mathrm{F}$ $\left(110 \pm 5^{\circ} \mathrm{C}\right)$. The sample is then cooled to room temperature for about 1 to 3 hours and then soaked in water for the 15 to 19 hours. The method requires the samples to be submerged for the soaking period. After the soaking period the entire sample is placed on a large absorbent cloth and rolled until all visible water is removed as indicated by the aggregate having a dull appearance. The larger particles may be wiped individually. A moving stream of air can be used to assist in the drying process. The mass of the sample in the saturated surface-dry condition is measured to the nearest 1.0 gram or 0.1 percent of the sample mass. The sample is immediately placed in a container and its mass in water at $23.0 \pm 1.7^{\circ} \mathrm{C}\left(73.4 \pm 3^{\circ} \mathrm{F}\right)$ is determined to the nearest 0.1 gram or 0.1 percent of sample mass. The sample is then dried to constant weight in an oven regulated at $230 \pm 9^{\circ} \mathrm{F}\left(110 \pm 5^{\circ} \mathrm{C}\right)$ and then cooled to room temperature for about 1 to 3 hours. After the sample reaches comfortable handling temperature the oven dry weight is recorded to the nearest $1.0 \mathrm{~g}$ or $0.1 \%$ of total weight, whichever is greater. The three mass measurements are used to determine the specific gravity and absorption values of the sample.

Even though the methods for testing the sample are relatively simple to conduct, they have some key shortcomings in terms of subjectivity of measurements, precision and time requirements for the test procedure as follows (West et al. 2007) :

The technique used to determine the SSD state of coarse aggregates is based on observation and is subjective which can lead to inconsistency between different operators. Some operators may do it based on the water film shine whereas others might judge it based on the color change in the aggregates. Hence the determination of the SSD state is highly operator dependent and the mass of SSD sample and the calculated specific gravity and absorption values are less repeatable and reproducible. 
Since the standard AASHTO T 85 test method requires more than an entire working day to be performed it makes this method inefficient for quality control purposes where the results are required as rapidly as possible.

\subsection{ALTERNATE TEST METHODS}

Several new modifications and test methods are available to determine the specific gravity and absorption of fine and coarse aggregates. These include simple changes in determining the SSD state of aggregates or an entirely new method of measuring the specific gravity using other commercially available equipment in the market. Some of the modifications are discussed briefly in the following discussion.

\subsubsection{Modifications to Available Test Methods}

Kruger et al. (1992) proposed alternate methods for establishing the SSD condition of fine aggregates. The methods that were discussed are (1) comparing the color of test sample with that of the oven dry sample, (2) determining the free flow state of the test sample using a tilted pan, (3) determining of flow of individual aggregate particle using a tilted masonry trowel, and (4) determining the surface dry state of fine aggregate using a water-soluble-glue tape. These methods are currently being used by the Texas Department of Transportation (DOT) test procedure Tex-201-F, Test Procedure for Bulk Specific Gravity and Water Absorption of Aggregate.

A calorimetric procedure was proposed by Kandhal and Lee (1970), which determines the SSD condition of the fine aggregate particles based on the color of aggregate which is dyed with a special chemical. This method of determining the SSD state of aggregates is an optional method in ASTM C 128. The drawback in this method is that the dye does not show well on dark aggregates and hence the determination of color change becomes subjective.

Other research efforts in finding a method for identifying the SSD state of fine aggregates include Howard's glass jar method, Hughes and Bahramian's saturated air drying method, Saxer's absorption time curve procedure, and Martin's wet and dry bulb temperature method. Even though all these methods were intended to improve the accuracy in determining the SSD state of fine aggregates, these methods were either impractical for implementation or offered little improvement (Kandhal et al. 1999). 
The two new test methods available for finding the specific gravity and absorption of aggregate are the SSDetect and the AggPlus system using the CoreLok. The SSDetect system is used only for the fine aggregate testing. It measures the SSD condition of the aggregate using an infrared light tuned to water. This infrared signal looks for traces of water on the surface of the aggregate. The SSD condition can be measured accurately by measuring the amount of infrared reflectance. The AggPlus system using the CoreLok on the other hand uses a controlled vacuum system to seal the samples.

\subsubsection{SSDetect System}

The SSDetect system consists of two parts: automatic volumetric mixer (AVM) and infrared units as shown in Figure 2.1. The entrapped air in the sample and water mixture is removed by using the AVM unit and the SSD state of the sample is detected by the infrared unit. A detailed test procedure is described in ASTM D 7172, Standard Test Method for Determining the Relative Density (Specific Gravity) and Absorption of Fine Aggregates Using Infrared. The SSDetect system is essentially a two-step process and a brief description of the test method is as follows:

The first step includes pouring a dry sample of $500 \pm 0.1$ grams into a calibrated $500 \mathrm{ml}$ flask and covering it with approximately $250 \mathrm{ml}$ of water. Immediately after all the sample is poured into the flask and covered with water a timer is started. After five minutes, the flask is

filled up to the calibration mark and weighed. It is then agitated and vacuumed for approximately 11 minutes using the AVM unit. After the AVM unit is stopped the flask is re-filled up to the calibration mark and weighed. The film coefficient is determined using the masses of flask before and after the agitation and vacuum process. This film coefficient is used as a calibration factor for the infrared reflectance measurements to determine the SSD condition of the aggregate in the next step. This whole process takes approximately 30 minutes.

In the second step, a dry sample of $500 \pm 0.1$ grams is placed in the mixing bowl provided with the infrared unit. The film coefficient determined in the first step is keyed in the infrared unit. The infrared unit monitors the moisture content using the infrared light source and detector while water is injected and mixed with the sample. Water begins to gather on the surface of aggregate and absorb the infrared signal, once the permeable pores are filled. The infrared 
detection device will therefore no longer see the reflection of the infrared signal. The SSD condition is then recognized and the infrared unit is automatically stopped. The mass of sample in SSD state is then determined. Based on the masses of the dry sample, SSD sample, and flask filled with water, the specific gravity and water absorption values can be determined.

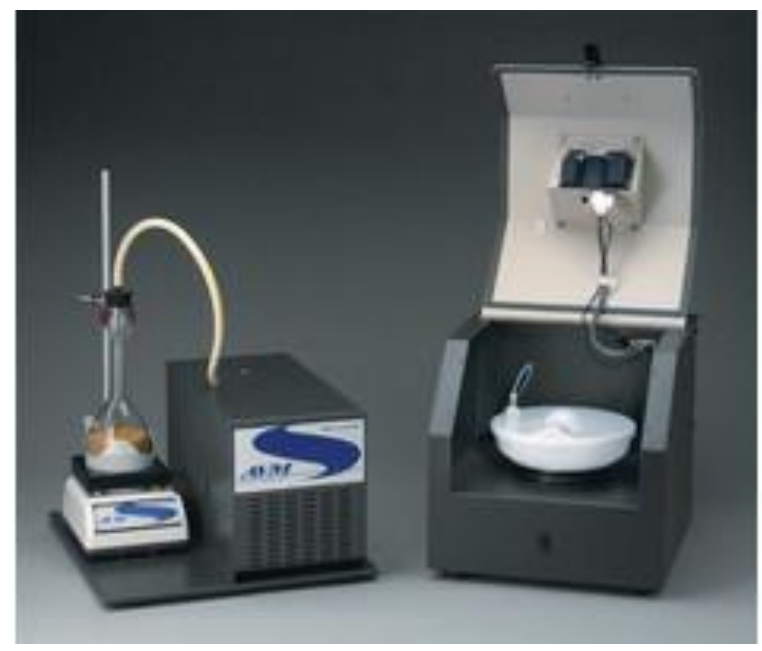

Figure 1 Automatic Volumetric Mixer and Infrared Units (Barnstead/Thermolyne)

Several studies have been conducted to evaluate the repeatability and reproducibility of the SSDetect system and the results were compared to those of the standard AASHTO T 84. Prowell and Baker (2005) conducted a round robin study with 12 laboratories using four crushed and two natural fine aggregate sources. The $\mathrm{G}_{\mathrm{sb}}$ results using the two methods were reported to be statistically different for three aggregates, including washed diabase, rounded natural sand, and angular natural sand. Both the SSDetect system and the AggPlus system yielded lower absorption and higher $\mathrm{G}_{\mathrm{sb}}$ values for washed diabase and diabase with more than 7.5 percent of dust. SSDetect measured higher absorption and lower $\mathrm{G}_{\mathrm{sb}}$ values for limestone, slag, rounded natural sand and angular natural sand that had lower dust contents when compared to AASHTO T 84. The precision of the SSDetect method was better than that of AASHTO T 84 and the AggPlus system.

Cross et al. (2006) found significant differences between the $\mathrm{G}_{\mathrm{sb}}$ and absorption results determined by the SSDetect and AASHTO T 84 methods. The SSDetect method produced the highest $\mathrm{G}_{\mathrm{sb}}$ results and the lowest absorption values which were followed by the AggPlus system 
and AASHTO T 84 methods. There was no significant difference in the $\mathrm{G}_{\mathrm{sa}}$ values found using the three methods. The SSDetect system has better reproducibility than the other two methods.

Bennert et al. (2005) evaluated the SSDetect system using 11 fine aggregates, which include six natural and five manufactured sands. These materials are common sources for HMA and concrete mixtures in New Jersey. The SSDetect system produces slightly higher absorption and lower $\mathrm{G}_{\mathrm{sb}}$ and $\mathrm{G}_{\mathrm{sa}}$ results than the AASHTO T 84 method. But the differences are less than those between the AggPlus and AASHTO T 84 methods. As evaluated in the study the SSDetect system has the best repeatability among the tested methods, SSDetect, AggPlus system and SSDrier.

You et al. (2008) evaluated the SSDetect system using 17 fine aggregate gradations made from natural sand, crushed sand, and steel slag. The SSDetect system had better precision than AASHTO T 84. The Gsb results from the SSDetect and AASHTO T 84 methods were not significantly different, but the Gsa values determined using these methods are statistically different (You et al. 2008).

\subsubsection{AggPlus System using CoreLok Device}

InstroTek, Inc. developed a method using a combination of a calibrated pycnometer and the CoreLok vacuum-sealing device. ASTM D7370 provides the standardized method for using the CoreLok. Figure 2 shows the devices used to find the specific gravity and absorption values. This set up can be used to find the specific gravity and absorption values of fine, coarse and combined aggregate samples.

The test procedure includes two separate methods, one for testing the fine aggregate samples and the other one for the coarse and combined aggregate samples. Both the methods are almost similar except for the sample sizes and pycnometer sizes used. To test the fine aggregates two samples of $500 \pm 3$ grams for testing in the pycnometer and one sample of $1000 \pm 5$ grams for vacuum saturation test are required. To test coarse or combined aggregate samples, two samples of $1000 \pm 5$ grams for testing in the pycnometer and one sample of $2000 \pm 10$ grams for the vacuum saturation test are required. The process for performing the test is well documented in the Instrotek manual (Instrotek ${ }^{\circledR}$ Inc.-CoreLok), so they are not provided in this thesis. 
The CoreLok method determines the percent absorption, apparent density, bulk specific gravity (SSD), and bulk specific gravity (dry weight basis). Software is provided by the manufacture to perform the required calculations.

The CoreLok method for determining aggregate bulk specific gravity is unique in that the sample is never brought to a saturated surface dry state. The bulk specific gravity of the sample in the dry state is determined from the dry weight in air and the weight of the sample submerged in water in an unsaturated state. The test for the bulk specific gravity must be completed within two minutes to minimize water absorption into the voids in the aggregate.

Several researchers have evaluated the AggPlus system using the CoreLok device. Hall (2004) conducted a study to find the $\mathrm{G}_{\mathrm{sa}}, \mathrm{G}_{\mathrm{sb}}$, and absorption of coarse, fine, and combined aggregates using the current standard AASHTO methods (AASHTO T 84 and AASHTO T 85) and the AggPlus system. The materials tested included six coarse aggregate sources whose absorption varied from 0.3 to 2.1 percent, five fine aggregate sources with minus No. 200 material ranging from 0.1 to 25.6 percent, and ten combined aggregates. One operator conducted testing of all five replicates for each aggregate using the three test methods. The AggPlus system tended to produce higher $\mathrm{G}_{\mathrm{sb}}$ results and lower absorption results for the coarse aggregates tested. Also, $\mathrm{G}_{\mathrm{sb}}$ results for some fine aggregates determined using the AASHTO T 84 and AggPlus procedures were significantly different at $95 \%$ confidence level.

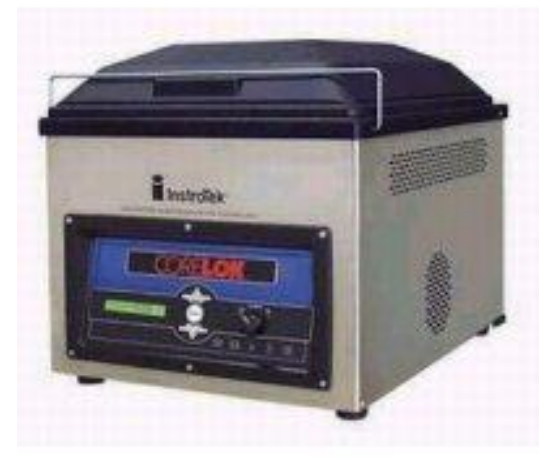

Figure 2 CoreLok Device

AASHTO T 84 and T 85 cannot measure the specific gravity of blended coarse and fine aggregates. However the results from the two tests can be mathematically combined if the 
proportion of the aggregate in the blend is known. Hall (2004) did the mathematical blending to compare to the AggPlus results for the blended aggregates. The AggPlus values and the mathematically combined values were not the same, but the relationships were consistent. Test results using the AggPlus system were not sensitive to nominal maximum aggregate size, gradation, or mineralogy. Hall (2004) concluded there was a need to improve the test consistency and compatibility of the AggPlus results in order to use the AggPlus in place of the existing methods.

Sholar et al. (2005) compared AggPlus to the standard AASHTO methods. The evaluation included 11 coarse aggregate sources with absorption ranging from 0.5 to 3.8 percent and seven fine aggregate sources. One operator tested two replicates for individual aggregates using the three test methods. The AggPlus system produced higher $\mathrm{G}_{\mathrm{sb}}$, and the difference was higher with high absorptive aggregates, for the coarse aggregate materials. The absorption values produced from the AggPlus system were lower than those produced by the standard method, and the difference was even higher in case of high absorptive aggregates. The $\mathrm{G}_{\mathrm{sb}}$ values were not significantly influenced by the aggregate gradation. The AggPlus system had a better repeatability than the standard test method with respect to the bulk specific gravity.

For fine aggregates, both the AggPlus and AASHTO methods had similar $\mathrm{G}_{\mathrm{sb}}$ values for three low absorptive granite aggregates but different $\mathrm{G}_{\mathrm{sb}}$ values for four high absorptive limestone aggregates. The AggPlus system produced slightly higher $\mathrm{G}_{\mathrm{sb}}$ values for granite aggregates and lower $\mathrm{G}_{\mathrm{sb}}$ values for limestone aggregates. The repeatability of the AggPlus system was better than AASHTO T 84 method for $G_{\text {sb. }}$ The difference in $G_{s b}$ would result a change of 5.5 percent for VMA, which would make it impractical to use in the existing HMA specifications. The authors did not recommend the use of AggPlus system as a test procedure for determining the $\mathrm{G}_{\mathrm{sb}}$ and absorption of aggregates.

Mgonella and Cross (2005) compared the AggPlus system to the standard AASHTO methods. The testing plan included eight crushed coarse aggregates with absorption ranging from 0.6 to 3.5 percent and 14 fine aggregates of various types. The tests were conducted by two operators to determine the interaction between the test methods and the operators. The authors reported coarse aggregates $\mathrm{G}_{\mathrm{sb}}$ values determined by the AggPlus system were statistically 
different from the AASHTO T 85 method. The AggPlus system tended to produce higher $\mathrm{G}_{\mathrm{sb}}$ and lower absorption values. No interactions were found between $\mathrm{G}_{\mathrm{sb}}$ values and operators. The reproducibility for the two tests was similar. The authors did not recommend the AggPlus procedure as a replacement for the current AASHTO T 85 method. In case of fine aggregates, the study found no significant difference in the $G_{s a}$ values. But the $G_{s b}$ values found using the AggPlus system and the AASHTO T 84 methods were statistically different. The AggPlus system tended to produce higher $\mathrm{G}_{\mathrm{sb}}$ values. The AggPlus system had a better repeatability than AASHTO T 84.

Prowell and Baker (2005) in which the AggPlus system and the AASHTO T 84 method were evaluated in a round-robin study conducted with 12 laboratories, using six fine aggregate materials, which included four crushed and two natural sources. The $\mathrm{G}_{\mathrm{sb}}$ values from the two test methods were statistically different for three of the six aggregates, including limestone, washed diabase, and blast furnace slag. The AggPlus system produced higher $\mathrm{G}_{\mathrm{sb}}$ and lower absorption values for two materials which had dust contents of 7.5 percent and above. The precision indices of the AggPlus system were not as good as those of the AASHTO T 84. The authors suggested that precision would improve as technicians became more familiar with the AggPlus system.

Bennert et al. (2005) conducted a study that compared the AggPlus system to AASHTO T 84 using two operators and 11 fine aggregates, which included six natural and five manufactured sands. The authors reported that the AggPlus system produced higher absorption results, which was a different finding from the other studies. The $\mathrm{G}_{\mathrm{sb}}$ results determined using the AggPlus system were statistically different from those of AASHTO T 84. The AggPlus system had a better repeatability when determining the $\mathrm{G}_{\mathrm{sb}}$ values.

\subsubsection{Arizona DOT Method}

The procedure followed by Arizona DOT (ARIZ 211d) is similar to that of AASHTO T 84 method with just a small difference. Here the weight of representative sample is 1200 grams when compared to $1000 \mathrm{~g}$ in AASHTO T 84.

\subsubsection{Wisconsin Method}

The Wisconsin method (Modified AASHTO T 84) of finding the specific gravity and absorption of fine aggregates is a modification of the AASHTO T 84 method. The only 
difference between the Wisconsin and the AASHTO T 84 method is that the material tested in the Wisconsin method does not include the material passing the No. 200 sieve.

\subsubsection{Iowa Method}

The Iowa method (Matls. IM 380) of finding the fine aggregate specific gravity and absorption values requires the sample to be covered with water and placed under $30 \mathrm{~mm}$ mercury vacuum for 30 minutes and then allowed to stand for another 20 minutes. The sample is then rinsed over the No. 200 sieve. The sample is said to have achieved the SSD state when the fine aggregate grains do not adhere to the steel spatula.

\subsubsection{Texas DOT Method}

According to the Texas DOT a fine aggregate sample is said to achieve SSD condition when two of the following four criteria are met by the sample:

1. Some oven dry sample is placed on a dry pan with a smooth bottom. Then the pan is tilted at a 45 degree angle to the table and the flow pattern of the sample is observed. Finally the test sample is placed on another dry pan and the pattern is observed. The sample is said to be surface dry if it flows in the same manner as that of the oven dry sample.

2. Some amount of oven dry sample is scooped into a trowel or similar equipment and tilted to one side. The flow of aggregate particles is observed. A similar amount of test sample is scooped and tilted in the same manner. If the test sample flows down same as the dry sample then it is surface dry.

3. Approximately $10 \mathrm{~cm}^{2}$ of paper tape is attached to a small block of wood with the adhesive side outside. Level the sample surface and place the taped face of the wooden block on the sample for 5 seconds. If the adhesive side feels sticky due to humidity rub it rapidly against a dry cloth. The wooden block and tape are gently lifted upward by taking proper care not to slide the taped face on the sample surface. The sample is said to be surface dry when no more than one particle adheres to the tape on two consecutive checks. 
4. The oven dry sample is scooped and placed over the test sample. The color change is observed periodically and the point at which the test sample appears to have the same color as of the dry sample it is said to be surface dry.

\subsubsection{California Method}

The California test 225 method to find the specific gravity and absorption of fine aggregates has a different method of finding the SSD state of the samples being tested. A portion of the test sample is taken and placed in a dry jar. The sample is said to have achieved the SSD condition when it stops to adhere to the dry surface of the glass jar. 


\section{Chapter 3 RESEARCH METHODOLOGY}

\subsection{INTRODUCTION}

The objective of this research study was to evaluate the alternate methods and find which methods would produce statistically similar specific gravity results when compared to the standard AASHTO methods. Also some test methods were selected so as to compare the repeatability of the test results. The research approach was as follows:

- Develop an experimental plan for the research.

- Selecting the aggregates that need to be tested and collection of aggregates.

- Selection of test methods for evaluating the specific gravity of aggregates being tested.

- Randomly divide the aggregates into samples.

- Performing the test methods using a randomized experimental plan

- Performing the required statistical analysis to compare the test results.

- Reporting the results.

\subsection{SAMPLE PREPARATION}

After the aggregate samples were brought to the laboratory they were stored at a dry place and were then reduced to testing sizes in accordance with AASHTO T-248. Two fine aggregate types and one coarse aggregate type were tested. The coarse aggregate material contained four different size aggregates.

For the coarse aggregate material, five samples of testing sizes were split from the aggregate stock (AASHTO T-11 and T-27) for each of the test method being performed i.e. AASHTO T 85 and the AggPlus. The samples were screened over the No. 4 sieve for the No. 8 material and the No. 8 sieve for the No. 9 material per the option allowed in the T 85 method. The samples were then tested as per the procedures in the test method being used.

The fine aggregate material was divided into fifty individual testing size samples. Five of the samples were prepared with a mass of 2500 grams for testing with the CoreLok; five were prepared with a mass of 1200 grams to test with the Arizona method; the remaining samples were prepared with a mass of 1000 grams. The samples were randomly selected for each of the 10 test methods. For the CoreLok and Arizona methods samples were randomly selected from 
the specimens prepared for those tests. Five samples were selected for each method. The Texas DOT method required the samples to be screened over No. 8 sieve and the retained material is discarded. For the Wisconsin method the sample was washed to remove material passing the No. 200 sieve.

The types of materials and tests are summarized in Table 1.

\section{Table 1 Sample Distribution}

\begin{tabular}{|c|c|c|c|}
\hline Type of Aggregate & $\begin{array}{c}\text { Number of } \\
\text { Samples Tested }\end{array}$ & $\begin{array}{c}\text { Number of Test } \\
\text { Methods }\end{array}$ & $\begin{array}{c}\text { Different Aggregate } \\
\text { Sizes }\end{array}$ \\
\hline Fine Aggregate (Limestone) & 5 & 10 & 1 \\
\hline Fine Aggregate (Slag) & 5 & 10 & 1 \\
\hline Coarse Aggregate (Limestone) & 5 & 2 & 4 \\
\hline
\end{tabular}

The test methods selected for evaluation were:

Fine Aggregates

AASHTO T 84

Provisional Cone Test

Provisional Surface Test

Hard Paper Method

Arizona DOT Method

Wisconsin Method

AggPlus System using CoreLok

device

Iowa Method

Texas DOT Method

California Test 225
Coarse Aggregates

AASHTO T 85

AggPlus System using the CoreLok device 


\section{Chapter 4 RESULTS AND ANALYSIS}

\subsection{INTRODUCTION}

There were four coarse aggregate sizes tested from a single source and two different sources of fine aggregates. The results obtained were used to draw the scatter diagrams in order to observe the trend followed by the specific gravity and absorption values obtained using the different methods. The values were then used to perform a Student $t$ distribution test to compare the values obtained by the alternative methods with those obtained by the standard AASHTO tests.

The test results for the fine aggregate specific gravity and absorptions for the Limestone aggregate type are presented in Appendix 1 which contains the data for the results produced. These results were calculated using the ten methods selected in order to be used for the statistical analysis to compare the difference between values. The results for the fine aggregate specific gravity and absorption for the slag aggregate type and those of the coarse aggregate specific gravities and absorption are also presented Appendix 1. Summary tables of the data are presented in Appendix 2.

\subsection{LIMESTONE FINE AGGREGATES}

Scatter diagrams for the limestone fine aggregate are shown in Figures 3, 4, and 5 for the bulk specific gravity, apparent specific gravity, and the absorption, respectively. Figure 3 indicates the AASHTO T84 method produced lower bulk specific gravity results than the other methods. The Wisconsin method produced higher results than the other results. The other eight methods produced results that appear to be similar. Differences between the test methods were anticipated as the different methods use alternative techniques for establishing the SSD condition for the aggregates. There are no clear trends in Figure 4 for the apparent specific gravity. This was expected as the apparent specific gravity is not dependent on the SSD state of the aggregates. The absorption trend is similar, but opposite of bulk specific gravity trend; as would be expected. This can be seen from Figure 5. 


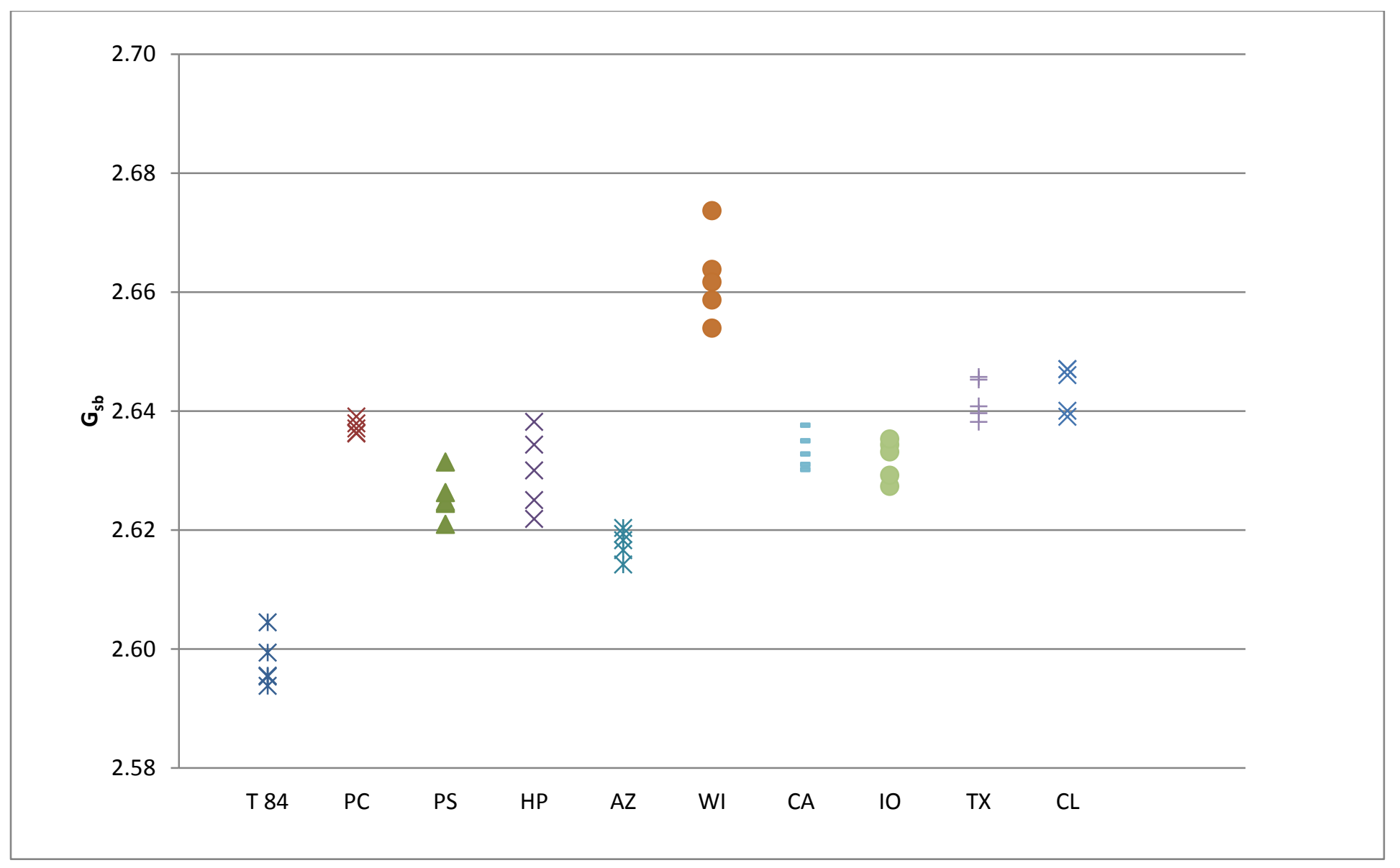

T 84= AASHTO T 84

$\mathrm{PC}=$ Provisional Cone Test

PS = Provisional Surface Test

HP $=$ Hard Paper Method

ADOT $=$ Arizona DOT Method

$$
\begin{aligned}
& \text { WM }=\text { Wisconsin Method } \\
& \text { CL }=\text { CoreLok Method } \\
& \text { IM }=\text { Iowa Method } \\
& \text { TX }=\text { Texas DOT Method } \\
& \text { CA }=\text { California Test } 225
\end{aligned}
$$

Figure 3 Comparison of $\mathrm{G}_{\mathrm{sb}}$ values from different tests for limestone fine aggregates 


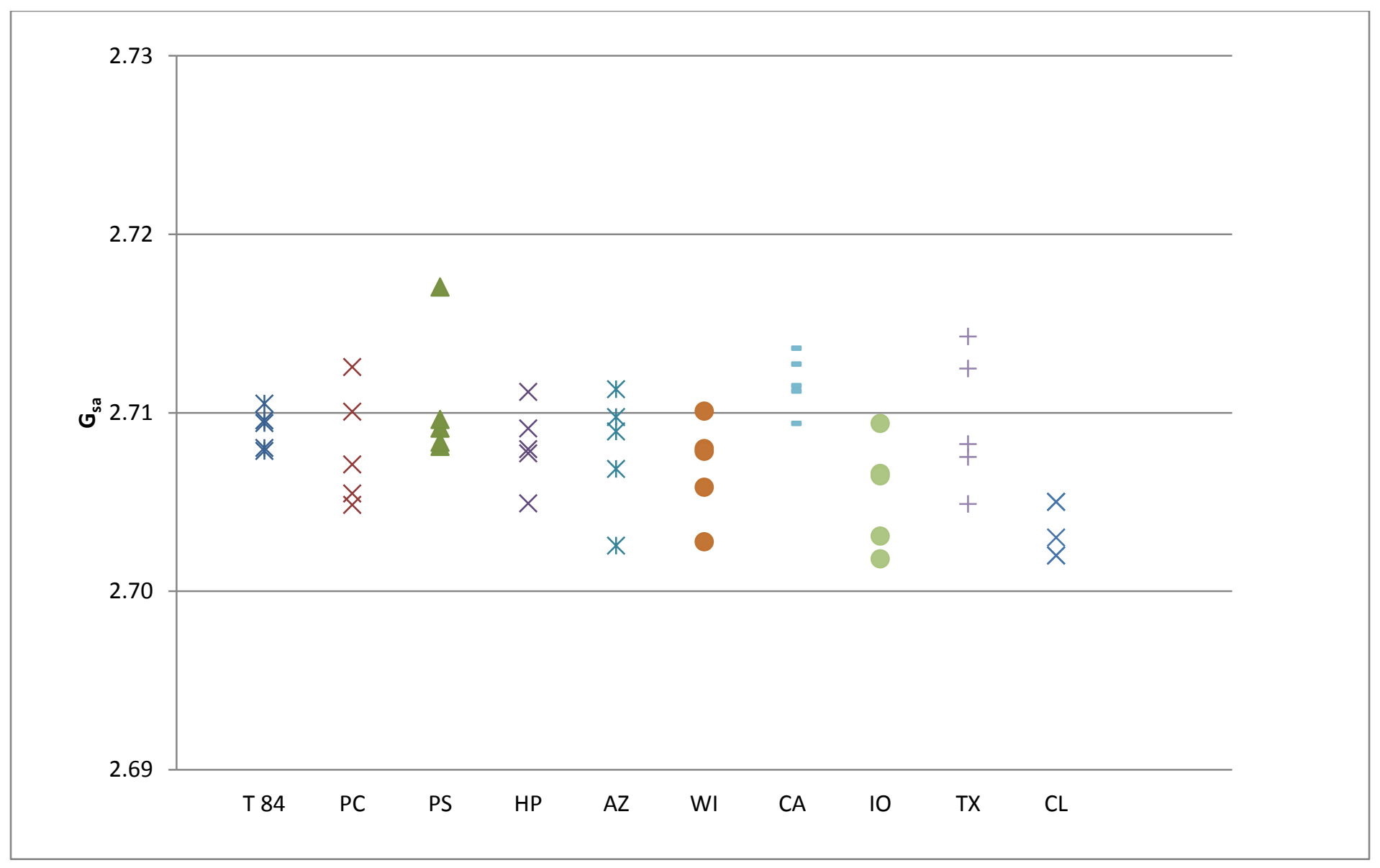

T 84= AASHTO T 84

$\mathrm{PC}=$ Provisional Cone Test

PS = Provisional Surface Test

HP $=$ Hard Paper Method

ADOT $=$ Arizona DOT Method

$$
\begin{aligned}
& \text { WM }=\text { Wisconsin Method } \\
& \text { CL }=\text { CoreLok Method } \\
& \text { IM }=\text { Iowa Method } \\
& \text { TX }=\text { Texas DOT Method } \\
& \text { CA }=\text { California Test } 225
\end{aligned}
$$

Figure 4 Comparison of $\mathrm{G}_{\mathrm{sa}}$ values from different tests for limestone fine aggregates 


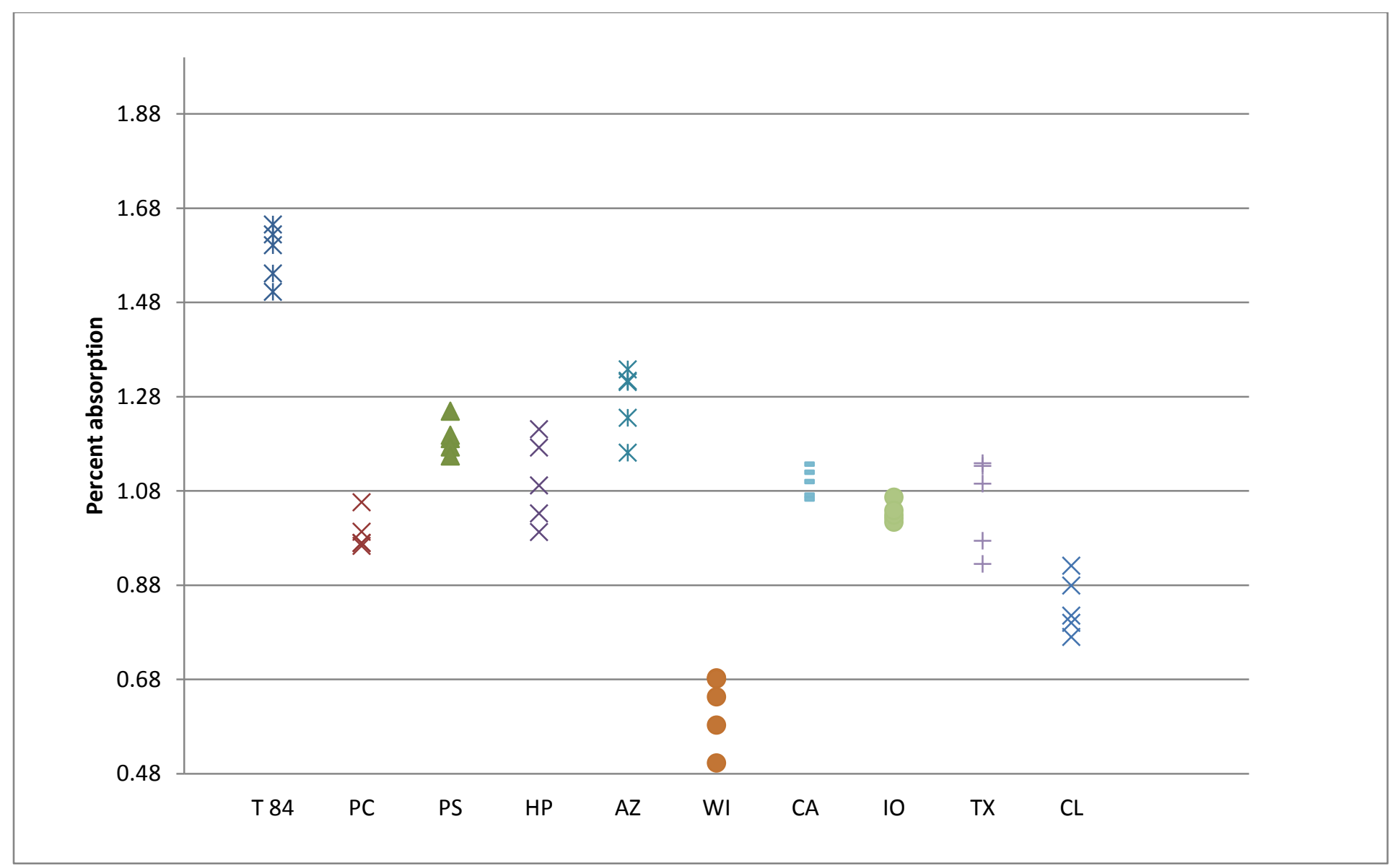

T 84= AASHTO T 84

$\mathrm{PC}=$ Provisional Cone Test

$\mathrm{WM}=$ Wisconsin Method

PS $=$ Provisional Surface Tes

$\mathrm{CL}=$ CoreLok Method

HP $=$ Hard Paper Method

$\mathrm{IM}=$ Iowa Method

ADOT $=$ Arizona DOT Method

TX $=$ Texas DOT Method

$\mathrm{CA}=$ California Test 225

Figure 5 Comparison of percent absorption values from different tests for limestone fine aggregates 
The student $t$ analysis was performed to compare the results of all combinations of test methods. The analyses output from Excel are presented in Appendix 3. When the p value is less than 0.05 the null hypothesis of equal means is rejected. When the p value is greater than 0.05 , there is insufficient evidence to reject the null hypothesis. Failure to reject the null hypothesis suggests the methods produce similar results. The $\mathrm{p}$ values greater than 0.05 in the analysis tables have bold fonts to indicate the test methods are similar. Tables 2, 3, and 4 present the $\mathrm{p}$ values for two tailed $t$ tests.

\section{Bulk specific gravity}

The Student t p-values, Table 2, for the bulk specific gravity of limestone fine aggregates shows the null hypothesis of equal means was rejected at the five percent level for all but 5 of the comparisons:

- Hard paper versus Provisional Surface

- Hard paper versus Iowa

- Hard paper versus California

- Iowa versus California

- CoreLok versus Texas

The Student t results help to verify observations about Figure 3. The AASHTO T84 method produced the lowest results. This test was performed without washing the aggregate so the concerns about the reliability of the method for an angular aggregate with high texture are present in the results performed in this analysis. The only difference between T84 and the Wisconsin method is washing the aggregate to remove the material passing the No. 200 sieve. The Wisconsin method produced the highest test results so it appears the dust is affecting the results. The difference between the $\mathrm{G}_{\mathrm{sb}}$ results obtained with $\mathrm{T} 84$ and the Wisconsin method was 0.064, which is in line with the informational note in the Appendix to the T84 method. All of the other methods, except CoreLok-AggPlus, were developed to compensate for the effect of minus No. 200 material. The CoreLok method does not use SSD and therefore should not be sensitive to the issues associated with SSD. 
Table 2 Student $p$ values for bulk specific gravity results for limestone fine aggregates 1

\begin{tabular}{|c|c|c|c|c|c|c|c|c|c|}
\hline Test Method & $\begin{array}{l}\text { Provisional } \\
\text { Cone }\end{array}$ & $\begin{array}{c}\text { Provisional } \\
\text { Surface }\end{array}$ & $\begin{array}{l}\text { Hard } \\
\text { Paper }\end{array}$ & $\begin{array}{c}\text { Arizona } \\
\text { DOT }\end{array}$ & Wisconsin & Corelok & Iowa & Texas & California \\
\hline Т 84 & 4.33E-08 & 4.63E-06 & $\begin{array}{c}1.74 \mathrm{E}- \\
05\end{array}$ & $1.72 \mathrm{E}-05$ & $1.46 \mathrm{E}-07$ & $1.09 \mathrm{E}-07$ & $\begin{array}{c}6.95 \mathrm{E}- \\
07\end{array}$ & $\begin{array}{l}9.19 \mathrm{E}- \\
08\end{array}$ & $3.57 \mathrm{E}-07$ \\
\hline $\begin{array}{c}\text { Provisional } \\
\text { Cone }\end{array}$ & & 0.0002 & 0.0393 & $2.08 \mathrm{E}-07$ & $6.71 \mathrm{E}-05$ & 0.0079 & 0.0100 & 0.0212 & 0.0250 \\
\hline $\begin{array}{c}\text { Provisional } \\
\text { Surface Test }\end{array}$ & & & 0.2452 & 0.0047 & 8.84E-06 & 0.0079 & 0.0252 & $\begin{array}{l}9.71 \mathrm{E}- \\
05\end{array}$ & 0.0074 \\
\hline Hard Paper & & & & 0.0050 & $8.13 \mathrm{E}-05$ & 0.0038 & 0.5675 & 0.0069 & 0.3234 \\
\hline $\begin{array}{c}\text { Arizona } \\
\text { DOT }\end{array}$ & & & & & $1.23 \mathrm{E}-06$ & $1.52 \mathrm{E}-06$ & $\begin{array}{c}6.72 \mathrm{E}- \\
05\end{array}$ & $\begin{array}{c}1.20 \mathrm{E}- \\
06\end{array}$ & $1.87 \mathrm{E}-05$ \\
\hline Wisconsin & & & & & & 0.0011 & $\begin{array}{c}3.02 \mathrm{E}- \\
05\end{array}$ & 0.0005 & $3.71 \mathrm{E}-05$ \\
\hline Corelok & & & & & & & 0.0009 & 0.4406 & 0.0015 \\
\hline Iowa & & & & & & & & 0.0016 & 0.4996 \\
\hline Texas & & & & & & & & & 0.0029 \\
\hline
\end{tabular}

${ }^{1}$ Bold values indicates insufficient evidence to reject null hypothesis of equal means 
Table 3 Student $p$ values for apparent specific gravity results for limestone fine aggregates ${ }^{1}$

\begin{tabular}{|c|c|c|c|c|c|c|c|c|c|}
\hline $\begin{array}{c}\text { Test } \\
\text { Method }\end{array}$ & $\begin{array}{c}\text { Provisional } \\
\text { Cone }\end{array}$ & $\begin{array}{c}\text { Provisional } \\
\text { Surface }\end{array}$ & $\begin{array}{l}\text { Hard } \\
\text { Paper }\end{array}$ & $\begin{array}{c}\text { Arizona } \\
\text { DOT }\end{array}$ & Wisconsin & Corelok & Iowa & Texas & California \\
\hline T 84 & 0.5056 & 0.4546 & 0.4493 & 0.4776 & 0.1415 & 0.0001 & 0.0375 & 0.8276 & 0.0172 \\
\hline $\begin{array}{l}\text { Provisional } \\
\text { Cone }\end{array}$ & & 0.3021 & 0.9260 & 0.9563 & 0.5791 & 0.0209 & 0.2384 & 0.5299 & 0.0522 \\
\hline $\begin{array}{c}\text { Provisional } \\
\text { Surface }\end{array}$ & & & 0.2787 & 0.2892 & 0.1264 & 0.0045 & 0.0496 & 0.6951 & 0.5120 \\
\hline Hard Paper & & & & 0.8783 & 0.4492 & 0.0045 & 0.1496 & 0.5307 & 0.0221 \\
\hline $\begin{array}{l}\text { Arizona } \\
\text { DOT }\end{array}$ & & & & & 0.6285 & 0.0272 & 0.2696 & 0.5058 & 0.0528 \\
\hline Wisconsin & & & & & & 0.0379 & 0.4580 & 0.2566 & 0.0100 \\
\hline Corelok & & & & & & & 0.2104 & 0.0108 & $3.06 \mathrm{E}-05$ \\
\hline Iowa & & & & & & & & 0.1037 & 0.0037 \\
\hline Texas & & & & & & & & & 0.2652 \\
\hline
\end{tabular}

${ }^{1}$ Bold values indicates insufficient evidence to reject null hypothesis of equal means 
Table 4 Student $p$ values for percent absorption results for limestone fine aggregates 1

\begin{tabular}{|c|c|c|c|c|c|c|c|c|c|}
\hline $\begin{array}{c}\text { Test } \\
\text { Method }\end{array}$ & $\begin{array}{l}\text { Provisional } \\
\text { Cone }\end{array}$ & $\begin{array}{c}\text { Provisional } \\
\text { Surface }\end{array}$ & $\begin{array}{l}\text { Hard } \\
\text { Paper }\end{array}$ & Arizona & Wisconsin & Corelok & Iowa & Texas & California \\
\hline Т 84 & $6.80 \mathrm{E}-08$ & 1.49E-06 & $9.21 \mathrm{E}-06$ & 7.68E-05 & $1.74 \mathrm{E}-08$ & $4.98 \mathrm{E}-08$ & $4.88 \mathrm{E}-08$ & $6.45 \mathrm{E}-06$ & $2.18 \mathrm{E}-07$ \\
\hline $\begin{array}{l}\text { Provisional } \\
\text { Cone }\end{array}$ & & 2.49E-05 & 0.0388 & $6.15 \mathrm{E}-05$ & $1.06 \mathrm{E}-05$ & 0.0015 & 0.0542 & 0.1857 & 0.0013 \\
\hline $\begin{array}{c}\text { Provisional } \\
\text { Surface }\end{array}$ & & & 0.0672 & 0.0623 & 3.43E-07 & 3.67E-06 & $2.48 \mathrm{E}-05$ & 0.0100 & 0.0021 \\
\hline Hard Paper & & & & 0.0112 & $1.83 \mathrm{E}-05$ & 0.0007 & 0.1553 & 0.4192 & 0.9670 \\
\hline Arizona & & & & & 7.29E-07 & $7.48 \mathrm{E}-06$ & 0.0001 & 0.0025 & 0.0012 \\
\hline Wisconsin & & & & & & 0.6297 & $2.53 \mathrm{E}-06$ & $3.17 \mathrm{E}-05$ & $1.18 \mathrm{E}-06$ \\
\hline Corelok & & & & & & & 0.0001 & 0.0020 & $2.97 \mathrm{E}-05$ \\
\hline Iowa & & & & & & & & 0.6688 & 0.0051 \\
\hline Texas & & & & & & & & & 0.2959 \\
\hline
\end{tabular}

${ }^{1}$ Bold values indicates insufficient evidence to reject null hypothesis of equal means 


\section{Apparent specific gravity}

Since the calculation of the apparent specific gravity does not include using the SSD weight, there should not be any difference between the values obtained for the apparent specific gravity when found using the different methods. By and large this expectation was met except for the CoreLok. From Table 3 it is clear that there were some cases in which the null hypothesis were rejected, which means that the values produced using those methods were not statistically similar when compared to some other methods. The CoreLok method produced values which were not statistically same when compared with any other method. The Iowa method produced statistically different values when compared to the standard AASHTO test and the provisional surface test. Finally the California method produced results that were statistically different from standard AASHTO, hard paper, Wisconsin, CoreLok and Iowa methods.

\section{Percent absorption}

The values obtained in most of the comparisons for the percent absorption values for the limestone fine aggregates were also statistically different from each other as can be seen from Table 4. The provisional cone test produced statistically similar results when compared to the values obtained from Iowa and Texas methods. Provisional surface method produced statistically similar results when compared to those obtained from hard paper and Arizona methods. The hard paper method produced statistically similar results when compared to the values obtained from Iowa, Texas and California methods. Wisconsin method produced similar results to those obtained from the CoreLok method, the Iowa method produced similar results when compared to those of the Texas method and finally Texas method produced statistically similar results to those obtained from California method.

\subsection{SLAG FINE AGGREGATES}

Scatter diagrams for the slag fine aggregate are shown in Figures 6, 7, and 8 for the bulk specific gravity, apparent specific gravity, and the absorption, respectively. Figure 6 indicates the Wisconsin, and Texas methods produced values that are consistently higher than the other methods. The results for the Iowa method were also higher than the other methods but the difference is less than with the Wisconsin and Texas methods. The other seven methods, including, AASHTO T84, appear similar. There are not clear trends in Figure 7 for the apparent specific gravity. This was expected as the apparent specific gravity is not dependent on the SSD 
state of the aggregates. The absorption trend is similar, but opposite of bulk specific gravity trend; as would be expected.

The Student $t$ analysis of the slag fine aggregate followed the same format as used for the limestone fine aggregate. Tables 5, 6, and 7 present the $\mathrm{p}$ values for two tailed tests of the slag fine aggregate.

\section{Bulk specific gravity}

The bulk specific gravity values obtained for the slag fine aggregates were more consistent than those obtained for the limestone fine aggregates, but still there were less than half cases in which the two methods compared produced statistically similar results, which can be seen from Table 5. The standard AASHTO T 84 method produced similar results to those obtained from the provisional cone, provisional surface and the hard paper method. Provisional cone method produced similar results when compared to those obtained from provisional surface, hard paper, Arizona and CoreLok methods. Provisional surface test produced similar results when compared to hard paper method. Arizona method produced statistically similar results when compared to those obtained from CoreLok method and California method. Finally Wisconsin method produced similar results when compared with Texas method and CoreLok method produced similar results when compared to California method.

\section{Apparent specific gravity}

The apparent specific gravity values for the slag fine aggregates obtained from the different test methods were all statistically similar when compared with each other. It can be seen from Table 6 that the null hypothesis cannot be rejected in any of the cases. This was due to the reason that calculation of apparent specific gravity does not include using the SSD weight of the aggregates and hence there would not be any difference between the values obtained using the different test methods. 


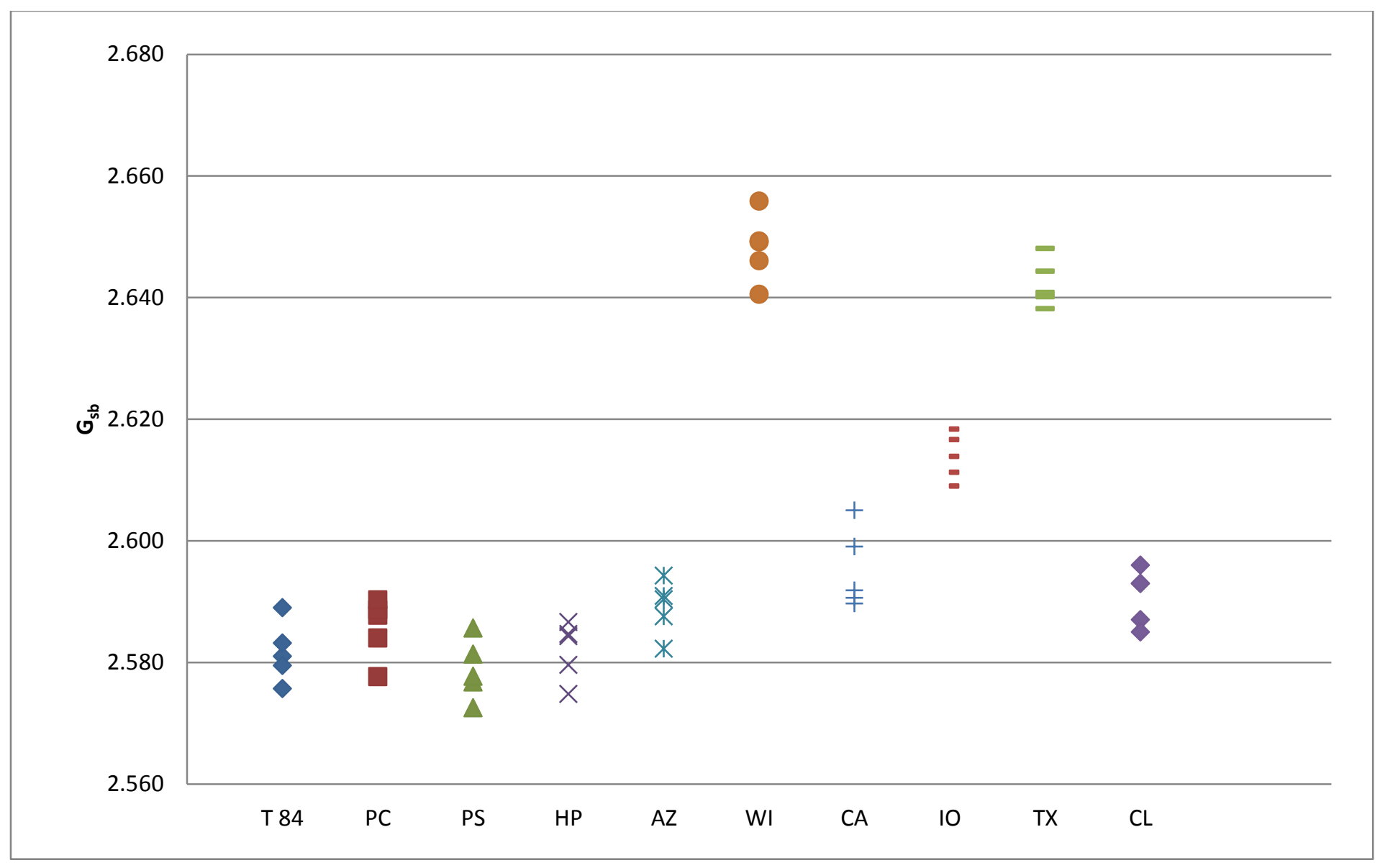

T 84= AASHTO T 84

$\mathrm{PC}=$ Provisional Cone Test

PS = Provisional Surface Test

HP $=$ Hard Paper Method

ADOT $=$ Arizona DOT Method
$\mathrm{WM}=$ Wisconsin Method

$\mathrm{CL}=$ CoreLok Method

$\mathrm{IM}=$ Iowa Method

TX $=$ Texas DOT Method

$\mathrm{CA}=$ California Test 225

Figure 6 Comparison of $\mathrm{G}_{\mathrm{sb}}$ values from different tests for slag fine aggregates 


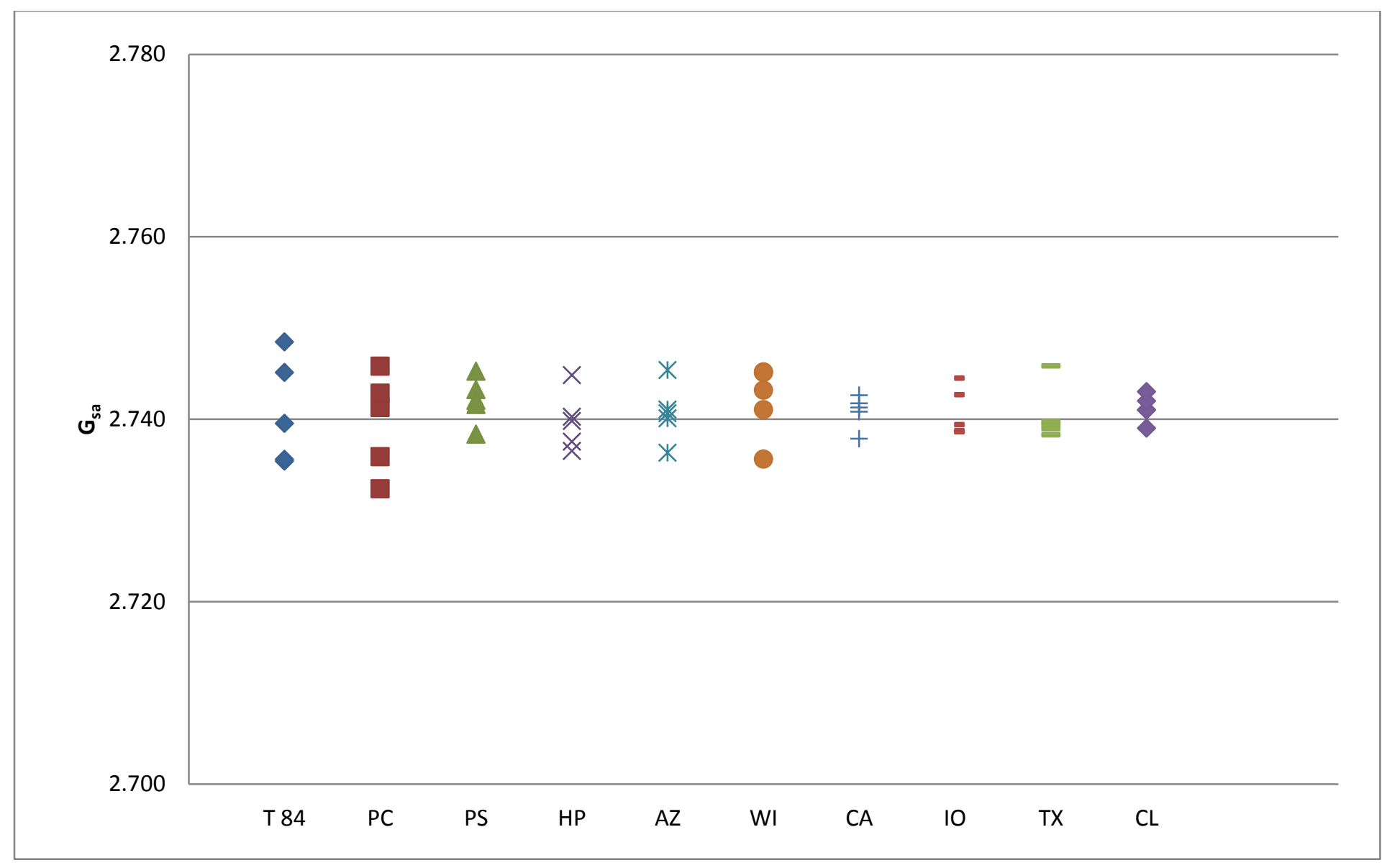

T 84= AASHTO T 84

$\mathrm{WM}=$ Wisconsin Method

$\mathrm{PC}=$ Provisional Cone Test

$\mathrm{CL}=$ AggPlus/CoreLok Method

PS = Provisional Surface Test

$\mathrm{IM}=$ Iowa Method

$\mathrm{HP}=$ Hard Paper Method

TX $=$ Texas DOT Method

ADOT $=$ Arizona DOT Method

$\mathrm{CA}=$ California Test 225

Figure 7 Comparison of $\mathrm{G}_{\mathrm{sa}}$ values from different tests for slag fine aggregates 


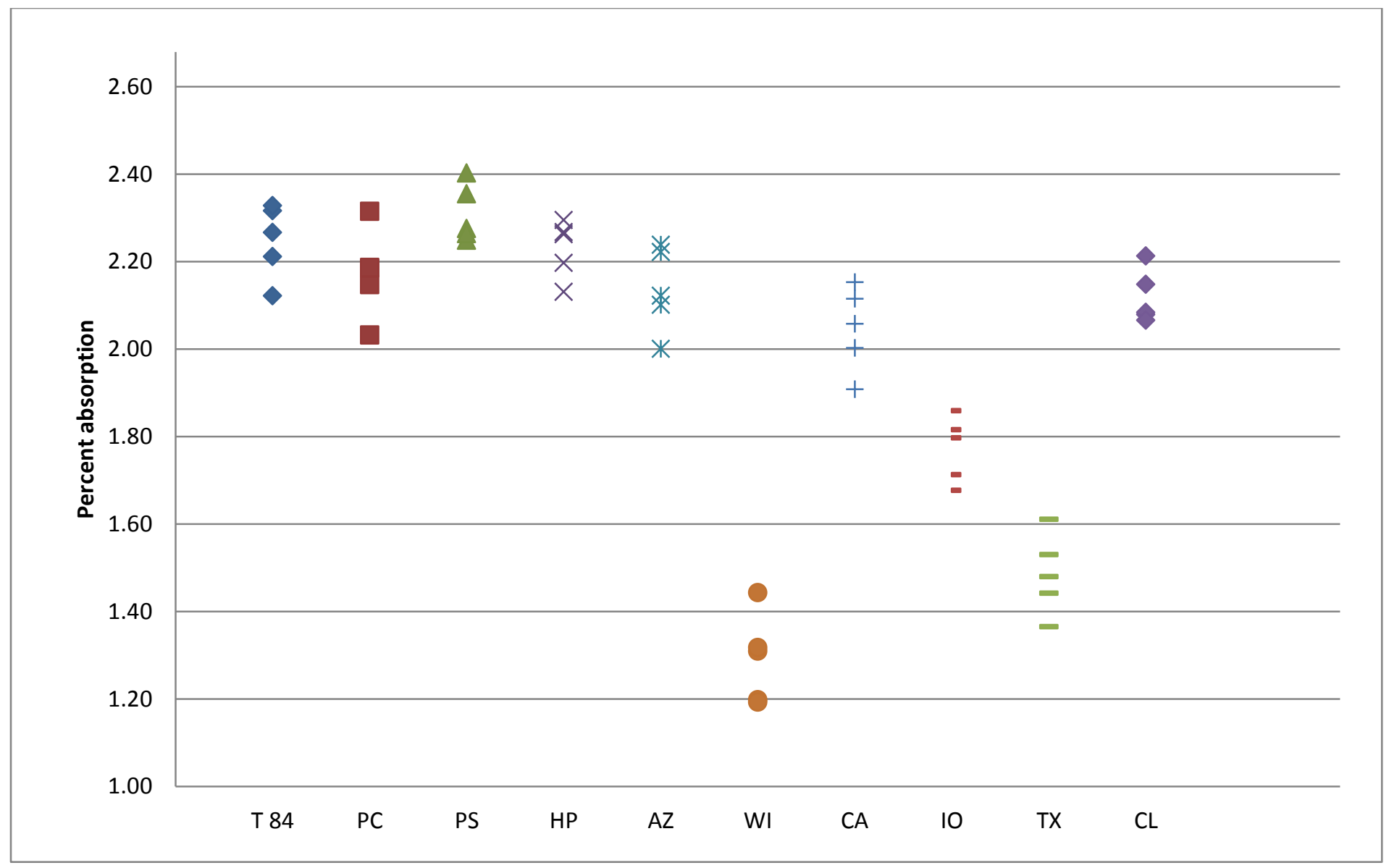

T 84= AASHTO T 84

$\mathrm{WM}=$ Wisconsin Method

$\mathrm{PC}=$ Provisional Cone Test

$\mathrm{CL}=$ AggPlus/CoreLok Method

PS = Provisional Surface Test

$\mathrm{IM}=$ Iowa Method

HP = Hard Paper Method

TX $=$ Texas DOT Method

ADOT $=$ Arizona DOT Method

$\mathrm{CA}=$ California Test 225

Figure 8 Comparison of percent absorption values from different tests for slag fine aggregates 
Table 5 Student $p$ values for bulk specific gravity results for slag fine aggregates ${ }^{1}$

\begin{tabular}{|c|c|c|c|c|c|c|c|c|c|}
\hline $\begin{array}{c}\text { Test } \\
\text { Method }\end{array}$ & $\begin{array}{l}\text { Provisional } \\
\text { Cone }\end{array}$ & $\begin{array}{c}\text { Provisional } \\
\text { Surface }\end{array}$ & $\begin{array}{l}\text { Hard } \\
\text { Paper }\end{array}$ & Arizona & Wisconsin & Corelok & Iowa & Texas & California \\
\hline T 84 & 0.2396 & 0.3838 & 0.9215 & 0.0383 & 4.0791E-08 & 0.0164 & $2.88 \mathrm{E}-06$ & $2.28 \mathrm{E}-08$ & 0.0061 \\
\hline $\begin{array}{l}\text { Provisional } \\
\text { Cone }\end{array}$ & & 0.0606 & 0.2693 & 0.2920 & 7.0668E-08 & 0.1306 & $8.53 \mathrm{E}-06$ & 4.26E-08 & 0.0323 \\
\hline $\begin{array}{c}\text { Provisional } \\
\text { Surface }\end{array}$ & & & 0.3306 & 0.0089 & 2.9459E-08 & 0.0041 & $1.51 \mathrm{E}-06$ & $1.6 \mathrm{E}-08$ & 0.0021 \\
\hline Hard Paper & & & & 0.0426 & $3.8527 \mathrm{E}-08$ & 0.018 & $2.72 \mathrm{E}-06$ & $2.08 \mathrm{E}-08$ & 0.0066 \\
\hline Arizona & & & & & $7.6866 \mathrm{E}-08$ & 0.5653 & $1.37 \mathrm{E}-05$ & 4.2E-08 & 0.1218 \\
\hline Wisconsin & & & & & & $1.04 \mathrm{E}-07$ & $3.21 \mathrm{E}-06$ & 0.0897 & 7.693E-07 \\
\hline Corelok & & & & & & & $2.55 \mathrm{E}-05$ & 5.99E-08 & 0.2509 \\
\hline Iowa & & & & & & & & $2.70 \mathrm{E}-06$ & 0.0006 \\
\hline Texas & & & & & & & & & $7.676 \mathrm{E}-07$ \\
\hline
\end{tabular}

${ }^{1}$ Bold values indicates insufficient evidence to reject null hypothesis of equal means 
Table 6 Student $p$ values for apparent specific gravity results for slag fine aggregates ${ }^{1}$

\begin{tabular}{|c|c|c|c|c|c|c|c|c|c|}
\hline $\begin{array}{c}\text { Test } \\
\text { Method }\end{array}$ & $\begin{array}{l}\text { Provisional } \\
\text { Cone }\end{array}$ & $\begin{array}{c}\text { Provisional } \\
\text { Surface }\end{array}$ & $\begin{array}{l}\text { Hard } \\
\text { Paper }\end{array}$ & Arizona & Wisconsin & Corelok & Iowa & Texas & California \\
\hline T 84 & 0.7486 & 0.6629 & 0.7372 & 0.9696 & 0.7103 & 0.8893 & 0.9936 & 0.8994 & 0.9864 \\
\hline $\begin{array}{c}\text { Provisional } \\
\text { Cone }\end{array}$ & & 0.3839 & 0.9596 & 0.7161 & 0.4487 & 0.5507 & 0.6796 & 0.7821 & 0.6436 \\
\hline $\begin{array}{c}\text { Provisional } \\
\text { Surface }\end{array}$ & & & 0.2403 & 0.4663 & 0.9739 & 0.5118 & 0.4475 & 0.3748 & 0.3985 \\
\hline Hard Paper & & & & 0.6646 & 0.3539 & 0.3960 & 0.6027 & 0.7519 & 0.5299 \\
\hline Arizona & & & & & 0.5768 & 0.7596 & 0.9614 & 0.8966 & 0.9229 \\
\hline Wisconsin & & & & & & 0.6738 & 0.5782 & 0.4964 & 0.5664 \\
\hline Corelok & & & & & & & 0.7709 & 0.6266 & 0.7543 \\
\hline Iowa & & & & & & & & 0.8474 & 0.9614 \\
\hline Texas & & & & & & & & & 0.7926 \\
\hline
\end{tabular}

${ }^{1}$ Bold values indicates insufficient evidence to reject null hypothesis of equal means 
Table 7 Student $p$ values for percent absorption results for slag fine aggregates ${ }^{1}$

\begin{tabular}{|c|c|c|c|c|c|c|c|c|c|}
\hline $\begin{array}{c}\text { Test } \\
\text { Method }\end{array}$ & $\begin{array}{c}\text { Provisional } \\
\text { Cone }\end{array}$ & $\begin{array}{c}\text { Provisional } \\
\text { Surface }\end{array}$ & $\begin{array}{l}\text { Hard } \\
\text { Paper }\end{array}$ & Arizona & Wisconsin & Corelok & Iowa & Texas & California \\
\hline T 84 & 0.2364 & 0.2450 & 0.7125 & 0.0871 & $2.2911 \mathrm{E}-07$ & 0.0234 & $1.32 \mathrm{E}-05$ & 8.06E-07 & 0.0079 \\
\hline $\begin{array}{l}\text { Provisional } \\
\text { Cone }\end{array}$ & & 2.4891E-05 & 0.3222 & 0.576 & 8.0743E-07 & 0.327 & 0.0001 & $3.56 \mathrm{E}-06$ & 0.0785 \\
\hline $\begin{array}{l}\text { Provisional } \\
\text { Surface }\end{array}$ & & & 0.0979 & 0.0111 & 7.3801E-08 & 0.0015 & $2.18 \mathrm{E}-06$ & $2.12 \mathrm{E}-07$ & 0.0011 \\
\hline Hard Paper & & & & 0.1122 & $1.3899 \mathrm{E}-07$ & 0.0242 & $7.25 \mathrm{E}-06$ & 4.64E-07 & 0.0081 \\
\hline Arizona & & & & & $9.4897 \mathrm{E}-07$ & 0.7232 & 0.0002 & 4.49E-06 & 0.1811 \\
\hline Wisconsin & & & & & & $3.21 \mathrm{E}-07$ & $3.04 \mathrm{E}-05$ & 0.014 & $2.214 \mathrm{E}-06$ \\
\hline Corelok & & & & & & & 4.6E-05 & $1.37 \mathrm{E}-06$ & 0.2051 \\
\hline Iowa & & & & & & & & 0.0007 & 0.0010 \\
\hline Texas & & & & & & & & & $1.342 \mathrm{E}-05$ \\
\hline
\end{tabular}

${ }^{1}$ Bold values indicates insufficient evidence to reject null hypothesis of equal means 


\section{Percent absorption}

As in the case of limestone fine aggregates, for the slag fine aggregates most of the test methods produced different results when compared with each other. This can be seen clearly from Table 7. The standard AASHTO T 84 method produced similar results compared to those of provisional cone, provisional surface, hard paper and Arizona methods. Provisional cone test produced similar results to those obtained from hard paper, Arizona, CoreLok and California methods. The results for provisional surface were similar to those of hard paper method. The results for hard paper method were similar to those of Arizona method. The results for Arizona were similar to those of CoreLok and California methods and finally the results for CoreLok were statistically similar to those obtained from the California method.

\subsection{COARSE AGGREGATES}

Scatter diagrams for the standard AASHTO T 85 method and the CoreLok method for the four different size aggregates are shown in Figures 9, 10, and 11 for the bulk specific gravity, apparent specific gravity, and the percent absorption, respectively. Figure 9 indicates the CoreLok method produced higher values of bulk specific gravity for each of the coarse aggregates tested. From Figure 10 it is clear that the CoreLok method produced lower apparent specific gravity values for all the four different size aggregates when compared to those obtained from the standard AASHTO T 85 method. The percent absorption trend is opposite of bulk specific gravity trend; as would be expected. This can be seen from Figure 11.

The Student $t$ analysis of the coarse aggregates followed the same format as used for the limestone fine aggregates. The $\mathrm{p}$-values for the Student $\mathrm{t}$ analysis of the coarse aggregate specific gravity and absorption are given in Table 8 . In every case the p-values indicate the hypothesis of equal means can be rejected at the 95 percent confidence level. 


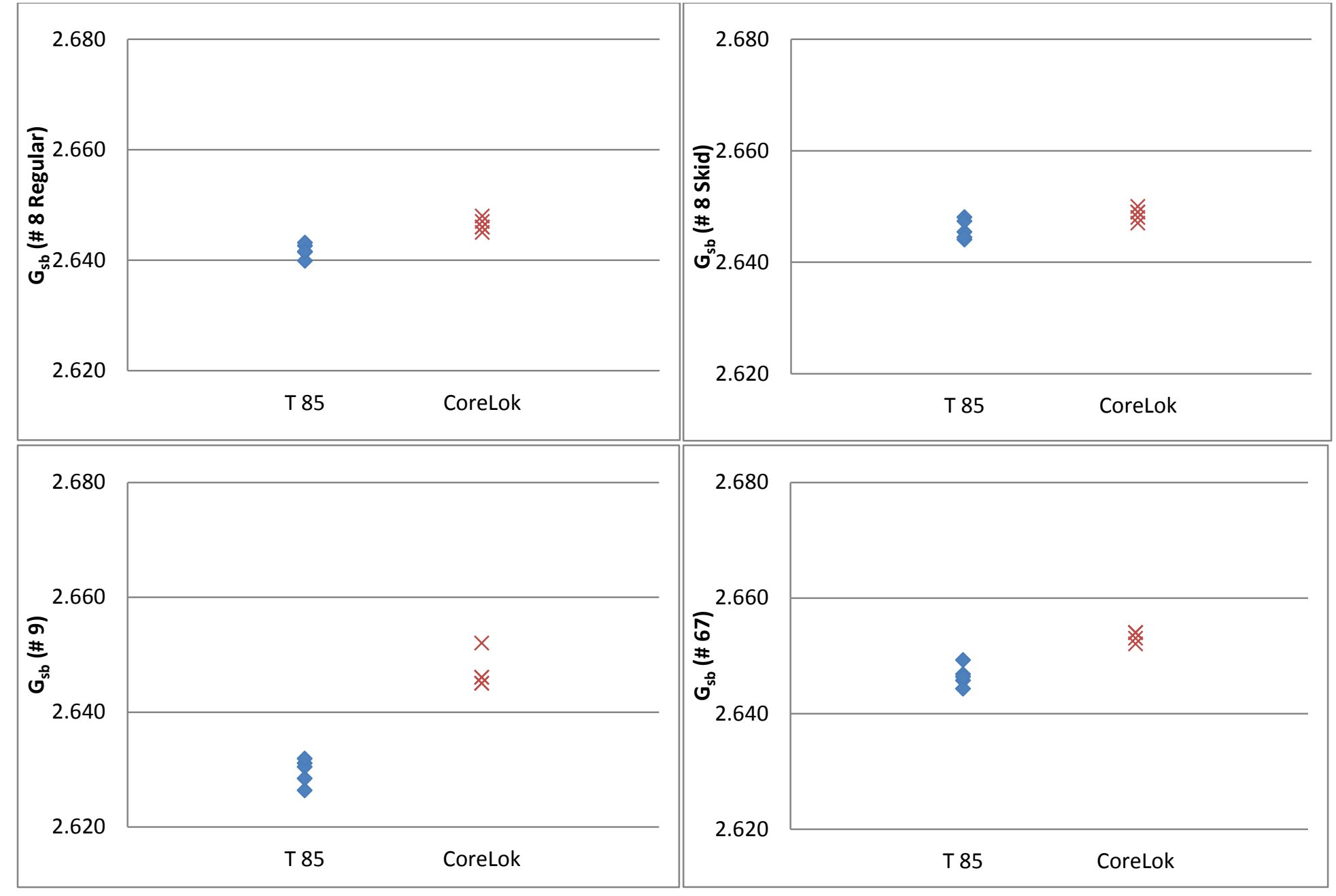

Figure 9 Comparison of $\mathrm{G}_{\mathrm{sb}}$ values for coarse aggregates 


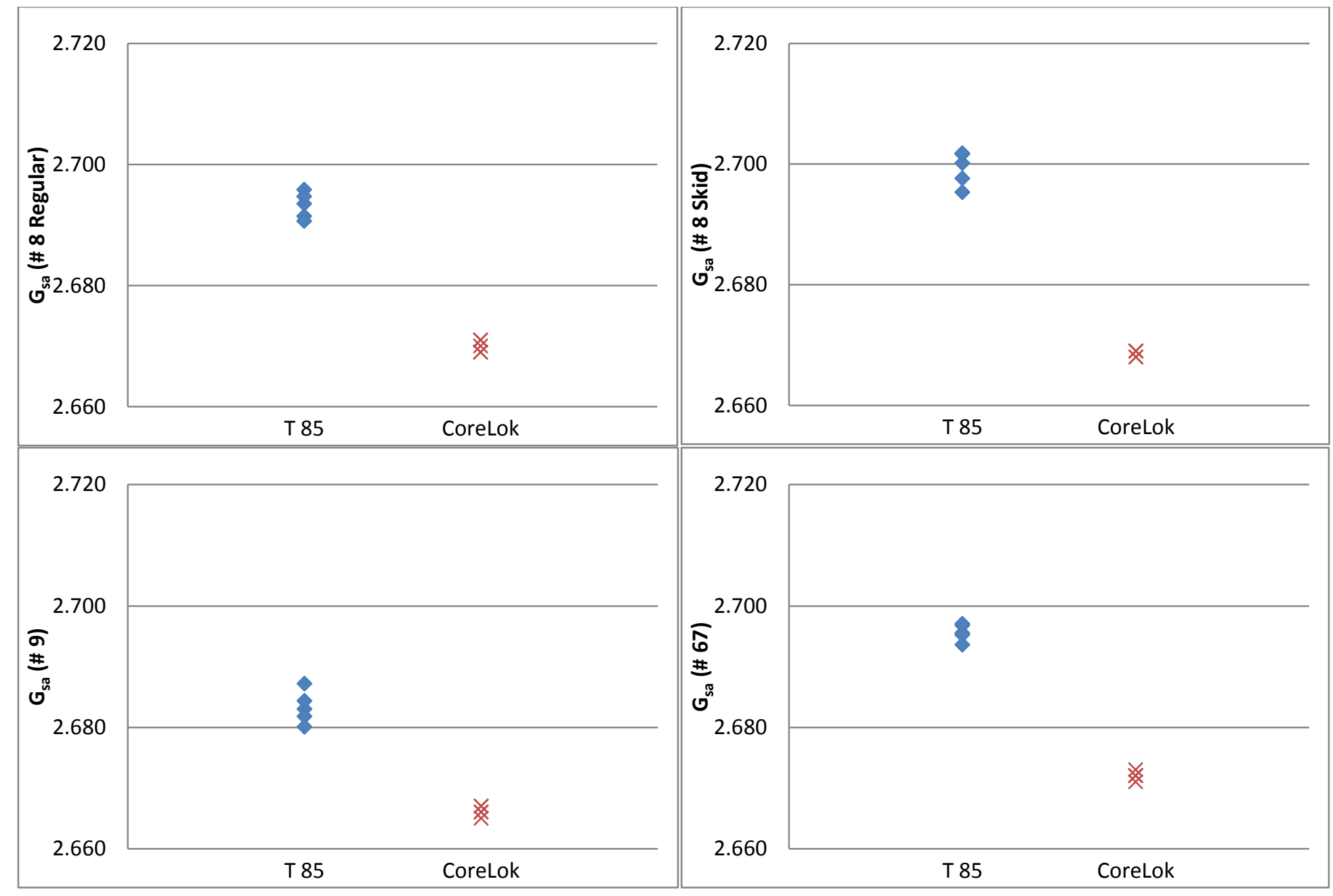

Figure 10 Comparison of $\mathrm{G}_{\mathrm{sa}}$ values for coarse aggregates 


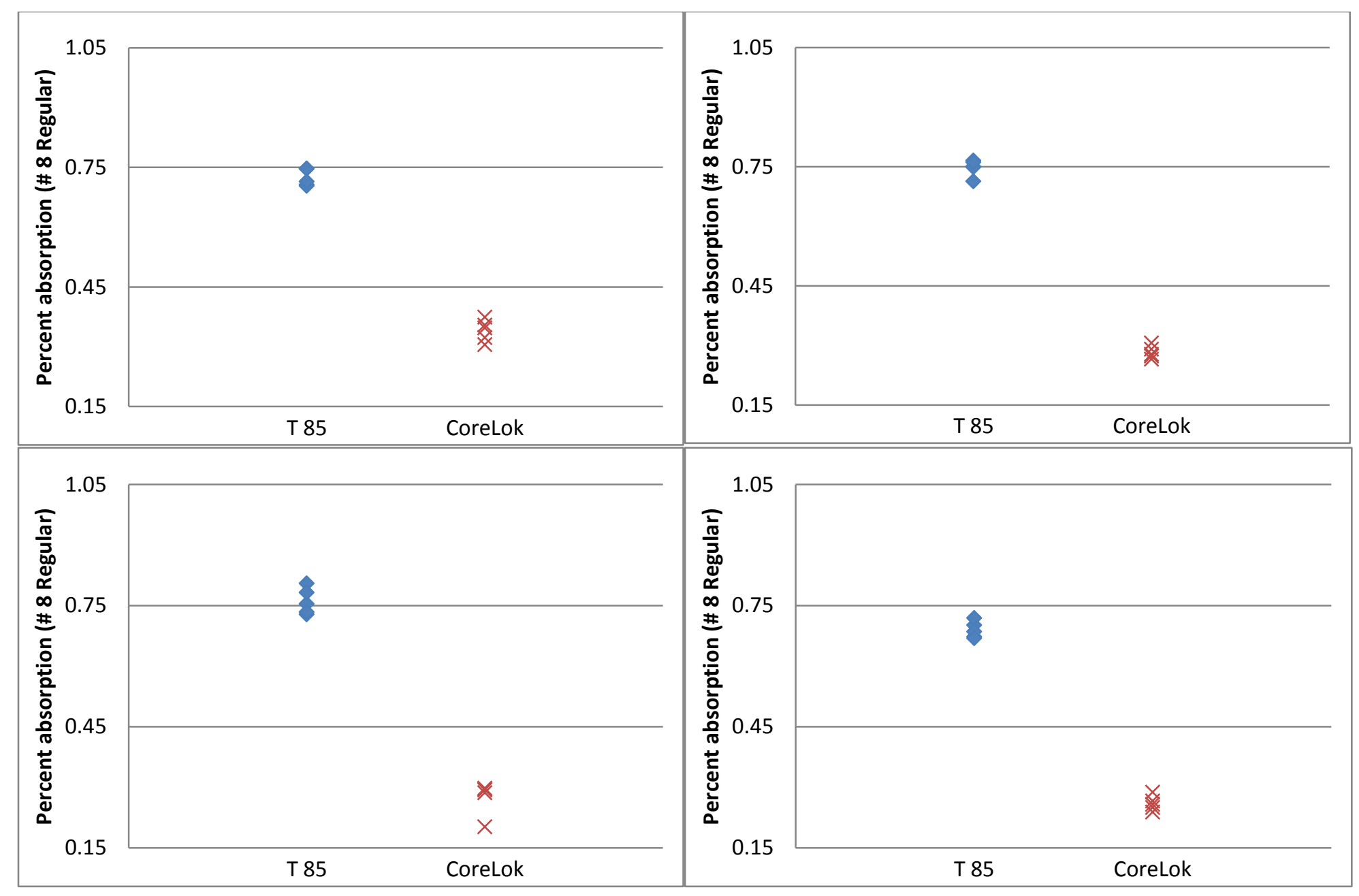

Figure 11 Comparison of percent absorption values for coarse aggregates 
Table 8 Coarse aggregate p-values from Student $t$ analysis for CoreLok versus T 85

\begin{tabular}{|c|c|c|c|}
\hline Aggregate & $\begin{array}{c}\text { Bulk } \\
\text { Specific } \\
\text { Gravity }\end{array}$ & $\begin{array}{c}\text { Apparent } \\
\text { Specific } \\
\text { Gravity }\end{array}$ & Absorption \\
\hline \# 8 regular & 0.0077 & $2.14 \mathrm{E}-08$ & $7.44 \mathrm{E}-09$ \\
\hline \# 8 Skid & 0.0191 & $9.37 \mathrm{E}-09$ & $1.73 \mathrm{E}-10$ \\
\hline$\# 9$ & $6.54 \mathrm{E}-06$ & $8.40 \mathrm{E}-07$ & $3.09 \mathrm{E}-08$ \\
\hline$\# 67$ & $6.08 \mathrm{E}-05$ & $6.06 \mathrm{E}-10$ & $5.56 \mathrm{E}-10$ \\
\hline
\end{tabular}

\subsection{VOLUMETRIC PROPERTIES}

The volumetric properties that are dependent on the bulk specific gravity calculations are the voids in mineral aggregate (VMA) and the voids filled with asphalt (VFA). From Equation 5 it is clear that keeping all the other parameters constant and changing the value of the bulk specific gravity of aggregates being used, the VMA can either be higher or lower based on the obtained results from different test methods. In case of the limestone aggregates fine the bulk specific gravity values obtained in all the alternative methods is higher than those obtained from the standard AASHTO T 84 test method. This would mean an increase in the VMA values. The VFA is dependent on the VMA and VTM of the mix. The following analysis is based on assuming the VTM is at the target value of mix design of 4 percent. Since the VTM is not varying in this analysis, VMA and VFA will show the exact same trends so only the VMA analysis is presented.

The potential effect of changing the test method to determine the bulk specific gravity of the aggregates was examined by computing the VMA and VFA of a mix assuming all other factors remained the same. The mix properties on the summary sheet were:

- $\mathrm{G}_{\mathrm{mm}}=2.476$

- $\mathrm{VTM}=4.0$

- $\mathrm{P}_{\mathrm{b}}=5.9$

- $\quad \mathrm{VMA}=15.7$

- Percent aggregate by type - 37\% No. 8, $14 \%$ No. 9 and $49 \%$ Fine aggregate 
These values were used to compute $\mathrm{G}_{\mathrm{mb}}=2.377$ for the mix and $\mathrm{G}_{\mathrm{sb}}=2.653$ for the aggregate blend ${ }^{1}$. The blended bulk specific gravity values for the aggregate blend were computed using each of the fine aggregate test methods and both the T85 and CoreLok method as presented in Table 9. Comparing the blend result using the T 84 method for the fine aggregates and T 85 for the coarse aggregate to the contractor's $\mathrm{G}_{\mathrm{sb}}$ value shows a difference of 0.032. The precision statements for $\mathrm{T} 84$ and $\mathrm{T} 85$ indicate the difference in test results between two labs should be less than 0.066 and 0.038 respectively. Hence, the test results measured in this work are in reasonable agreement with the contractor's results.

\section{Table 9 Blended bulk specific gravity values}

\begin{tabular}{|c|c|c|c|c|c|c|c|c|c|c|}
\hline & \multicolumn{10}{|c|}{ Fine aggregate test method } \\
\hline 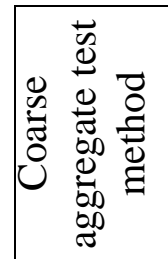 & T 84 & $\mathrm{PC}$ & PS & $\mathrm{HP}$ & $\mathrm{AZ}$ & WI & CA & $\mathrm{IO}$ & TX & $\mathrm{CL}$ \\
\hline $\mathrm{T} 85$ & 2.621 & 2.641 & 2.635 & 2.637 & 2.631 & 2.653 & 2.639 & 2.638 & 2.643 & 2.644 \\
\hline $\mathrm{CL}$ & 2.623 & 2.643 & 2.637 & 2.639 & 2.633 & 2.655 & 2.641 & 2.640 & 2.645 & 2.646 \\
\hline
\end{tabular}

The values in Table 9 were used to compute the VMA and VFA for the mix for the different values of aggregate bulk specific gravity. Figure 12 shows the VMA values vary from 14.7 to 15.8 depending on the test method. The lowest result is obtained from the AASHTO test methods, the maximum VMA was obtained using the Wisconsin method for the fine aggregates and the CoreLok method for the coarse aggregates. Figure 13 shows the line of equality graph comparing the effect of $\mathrm{T} 85$ versus the CoreLok method. There is good agreement between the methods, however the VMA values are consistently higher when $\mathrm{G}_{\mathrm{sb}}$ of the coarse aggregates is determined with the CoreLok. Figure 13 also demonstrates that the fine aggregate test method has a larger effect on VMA than the coarse aggregate test method. The maximum difference in VMA that could be attributed to the coarse aggregate test method is 0.1 while the maximum difference that could be attributed to the fine aggregate test method is 1.1 .

\footnotetext{
${ }^{1}$ The analysis of the effect of the different test methods for aggregate bulk specific gravity on the volumetric properties of asphalt concrete are approximations. In the mix design process, the specific gravity of the mix would change as a function of the specific gravity of the aggregates. The analysis presented herein only looks at trends that could occur due to different values of aggregate bulk specific gravity.
} 


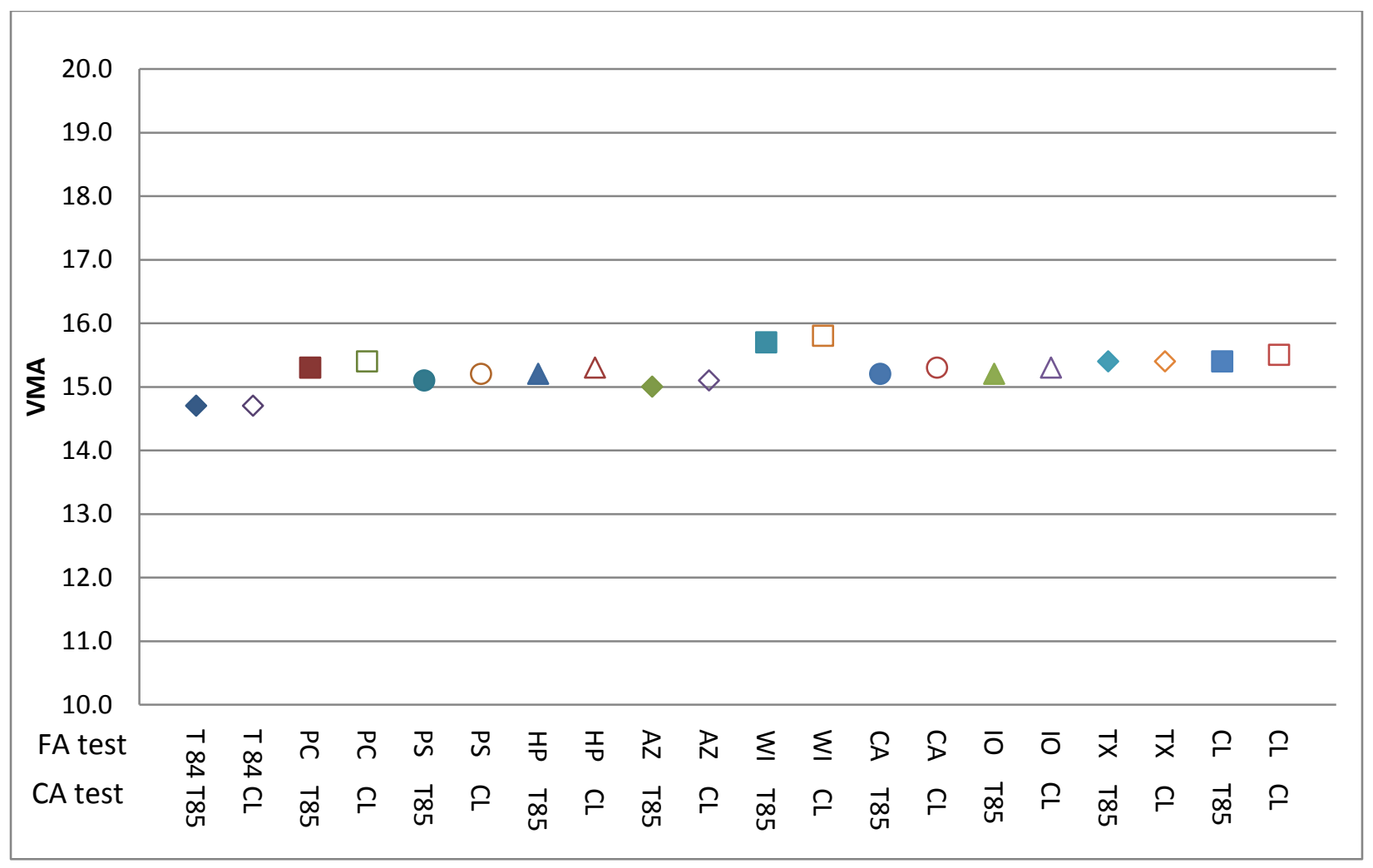

Figure 12 VMA values using specific gravity values from different methods

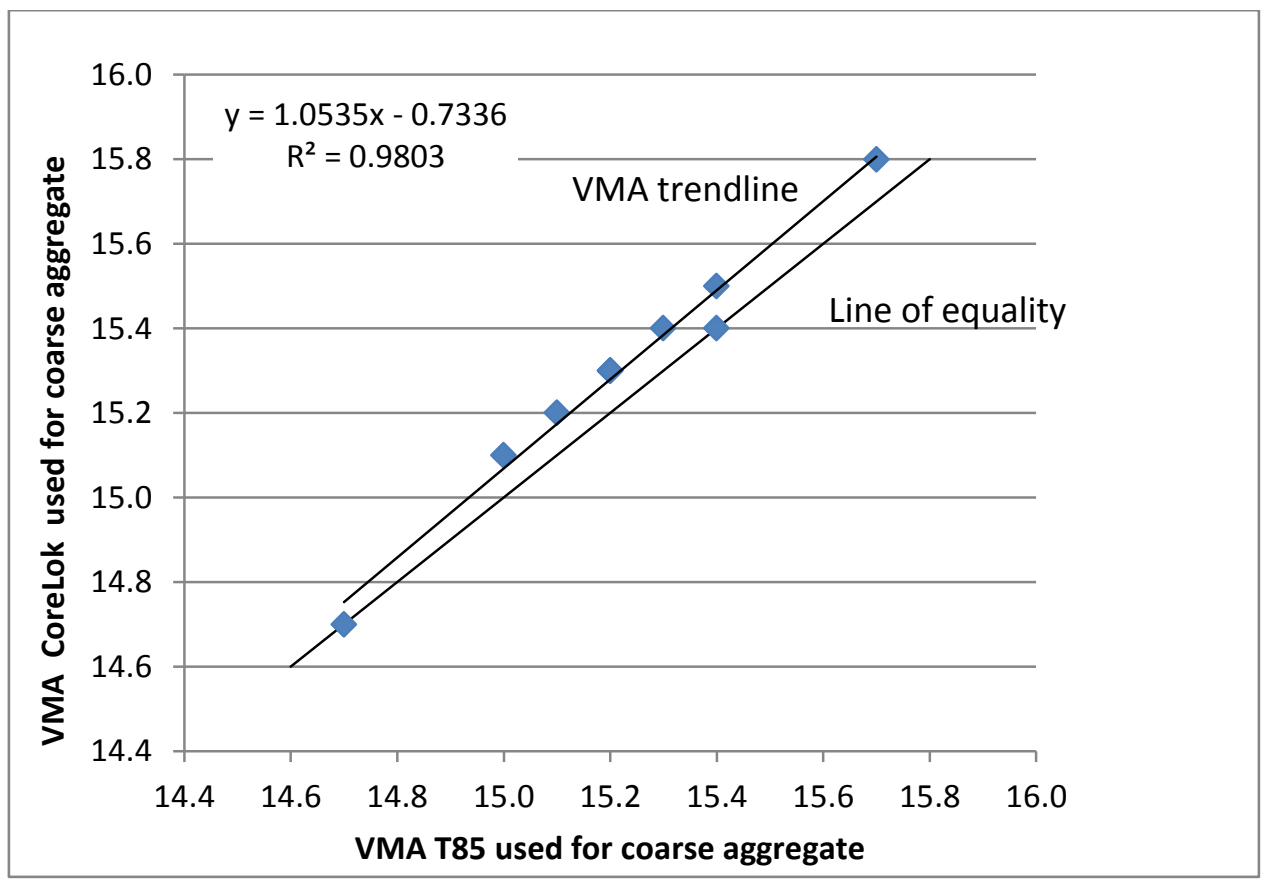

Figure 13 Line of equality comparison of VMA from different test methods 


\section{Chapter 5 CONCLUSIONS AND RECOMMENDATIONS}

The accurate determination of aggregate specific gravity is needed for proper determination of the volumetric properties of asphalt concrete mixes. The literature review demonstrated that there are at least ten different test methods for measuring the specific gravity and absorption of fine aggregates and two methods for coarse aggregates. The abundance of test methods for fine aggregates indicates the paving community is concerned over the accuracy and reliability of the standard methods in ASTM and AASHTO. In particular, there is concern in determining the saturated surface dry state of fine aggregates with high texture and angularity, such as the crushed limestone fine aggregate commonly used in West Virginia.

\subsection{CONCLUSIONS}

One of the difficulties in evaluating alternative test methods is the "truth" is not known. If it can be demonstrated that the standard method produces the truth then there would not be a need to examine alternative test methods. (Assuming the standard method can be performed in a "reasonable" amount of time, effort, equipment needs, etc.) The fine aggregate specific gravity results for limestone, Figure 3, demonstrate the $\mathrm{G}_{\mathrm{sb}}$ values obtained with the standard AASHTO method are lower than the values obtained with the alternative methods. The results obtained with the Arizona method are the next lowest. The only difference between T84 and the Arizona method is the amount of material saturated prior to starting the test, $1200 \mathrm{~g}$ for the Arizona method and $1000 \mathrm{~g}$ for T 84. It is difficult to hypothesize why testing with T 84 and the Arizona method would produce test results where the hypothesis of equal means is rejected. The T84 method precision statement indicates the single operator standard deviation is 0.011 and the difference between two tests performed by the same technician in the same laboratory is 0.032 . The standard deviation of the five samples tested with T 84 and Arizona were 0.004 and 0.002, respectively, far less than the $\mathrm{T} 84$ standard for standard deviation. The difference between the T 84 and Arizona method result was 0.020 , with in the norm for $\mathrm{G}_{\mathrm{sb}}$ testing.

The highest $\mathrm{G}_{\mathrm{sb}}$ value was obtained from the Wisconsin method. The primary difference between the standard and Wisconsin methods is the removal of material by washing the sample over the No. 200 sieve. (This process is actually presented in the AASHTO T 84 appendix as "non-mandatory information.) The difference between the $\mathrm{T} 84$ and Wisconsin method $\mathrm{G}_{\mathrm{sb}}$ methods was in the range identified in $\mathrm{T} 84$ for comparing washed and unwashed samples. 
Samples for the Iowa method are also washed over the No. 200 sieve, but the method for determining the SSD state is different from $\mathrm{T} 84$. The results with the Iowa method are near the midpoint between the $\mathrm{T} 84$ and Wisconsin method results.

The apparent specific gravity values for limestone fine aggregates using all the different methods showed that the CoreLok method, the Iowa method and the California test 225 produced statistically different results when compared to the standard AASHTO T 84 results. There was some inconsistency in the apparent specific gravity values obtained from the different alternative methods. The alternative methods showed statistically different results when compared to each of the other methods. Since the calculation of apparent specific gravity does not include using the SSD weight of aggregates being tested, it is questionable if it is true to have values that are different.

Very few methods showed statistical similarity in case of the absorption values calculated for the limestone fine aggregates. This inconsistency would prove to be very crucial in judging the water absorbing capacity of the mix for HMA mixes. Improper judgment of the absorption values can lead to a poor mix design for the HMA mixes.

The slag fine aggregates results with the T 84 and associated alternative methods showed consistent results. There was insufficient evidence to reject the hypothesis of equal means for when comparing T 84 to the provisional cone, provisional surface and hard paper methods. The Wisconsin method produced the highest Gsb values and the hypothesis of equal means was rejected for all of the comparisons to the other methods except for the Texas method. The Wisconsin and Texas methods produced statistically similar results.

For the calculation of apparent specific gravities values for slag fine aggregates, all the methods tested showed statistically similar results. It shows that since the SSD weight of aggregates is not included, there is not much difference between the values of apparent specific gravities for the slag fine aggregates. But when the absorption values were compared there was again some inconsistency in the results obtained. The results obtained in finding the absorption values for slag fine aggregates showed a similar trend to the bulk specific gravity values obtained but in reverse. Hence for absorption values the Wisconsin and Texas method produced the 
lowest values followed by the Iowa method. All the other test methods produced results similar to the standard test method.

For the coarse aggregates, the bulk specific gravity values obtained from the two test methods produced statistically different results for all the four sizes of aggregates tested. Although the statistical $t$ test rejected the hypothesis of equal means, the difference between the T 85 and CoreLok results was less than the d2s limit in the T85 precision statement.

\subsection{RECOMMENDATIONS}

This research was limited to testing just two sources of fine aggregates and one source of coarse aggregate. Further research can be done on some other types of aggregate sources in order to see if these methods work well with other aggregates. The aggregate types that are found to cause the problem of inaccurate judgment in SSD state of fine aggregates should be studied and used in further research.

Since this thesis was done in a single laboratory, there are chances of inaccuracies in operator judgments and hence the same types of aggregates need to be tested among other laboratories to have a better understanding of the operating errors in the experiments conducted. The use of high resolution cameras can help improve the accurate determination of the dull state of the aggregates reaching the SSD state. This can help in reducing the operator errors which can cause some changes in the results obtained for any test method. 


\section{REFERENCES}

Bennert, T., A. Maher, R. Patel, and J. Smith. An Evaluation of Automated Devices to Determine Bulk Specific Gravity of Fine Aggregates. Unpublished Paper, Rutgers University, 2005.

Cross, S. A., M. K. Mgonella, and Y. Jakatimath. Evaluation of Test Equipment for Determination of Fine Aggregate Specific Gravity and Absorption. In Transportation Research Record: Journal of the Transportation Research Board, No. 1952, TRB, National Research Council, Washington, D.C., 2006.

Determination of Percent Absorption and Specific Gravity of Aggregates Using the AggPlus ${ }^{\mathrm{TM}}$ System, Instrotek, Inc., Raleigh, NC, 2001.

Hall, K. D. Using a Single Test to Determine Specific Gravity and Absorption of Aggregate Blends. In Transportation Research Record: Journal of the Transportation Research Board, No. 1874, TRB, National Research Council, Washington, D.C., 2004.

Instrotek® Inc.-CoreLok, CoreLok manual, 2011. http://www.instrotek.com/pdfs/CoreLok_Manual

Kandhal, P., R. Mallick, and M. Huner. Development of a New Test Method for Measuring Bulk Specific Gravity of Fine Aggregates. NCAT Report 99-07, Auburn University, 1999.

Krugler, P.E., M. Tahmoressi, and D.A. Rand. , Improving the Precision of Test Methods Used in VMA Determination, Asphalt Paving Technology, Vol. 61, 1992.

Lee, D. Y., J. A. Guinn, P. S. Khandhal and R. L. Dunning. Absorption of Asphalt into Porous Aggregates. Publication SHRP-A/UIR-90-009. Strategic Highway Research Program, National Research Council, Washington, D.C., 1990.

Lee, D.Y. and P.S. Kandhal. An Evaluation of the Bulk Specific Gravity for Granular Materials. Highway Research Record No. 307, National Research Council, Washington, D.C., 1970. 
Prowell, B., and N. Baker. Round Robin Evaluation of New Test Procedures for Determining the Bulk Specific Gravity of Fine Aggregate. NCAT Report 05-07, Auburn University, 2005.

R.C. West, N.H. Tran, H. Azari, C. Ferraris. "NCHRP 04-35: Improved Test Methods for Specific Gravity and Absorption of Coarse and Fine Aggregate", August 2008.

Sholar, G. A, G. C. Page, J. A. Musselman, P. B. Upshaw, and H. L. Moseley. Investigation of the CoreLok for Maximum, Aggregate, and Bulk Specific Gravity Tests. Transportation Research Record: Journal of the Transportation Research Board, No. 1907, TRB, National Research Council, Washington, D.C.,2005.

West, R., E. Dukatz, J. Haddock, K. Hall, J. Kliewer, C. Marek, J. Musselman, A. Regimand, G. Sholar, and N. Tran. A Review of Aggregate and Asphalt Mixture Specific Gravity Measurements and Their Impacts on Asphalt Mix Design Properties and Mix Acceptance. Report Prepared by the Specific Gravity Task Group for the FHWA Asphalt Mix and Construction Expert Task Group, 2007.

You. Z., J. Mills-Beale, R. Williams, and Q. Dai. Investigation of a New Test Procedure for Measuring the Specific Gravities of Fine Aggregates in Michigan. Proceedings of the 2008 TRB Annual Meeting, CD-ROM, TRB, National Research Council, Washington, D.C., 2008. 


\section{APPENDIX 1 Data}

\section{Limestone Fine Aggregates}

Standard AASHTO T 84

\begin{tabular}{|c|c|c|c|c|c|c|c|}
\hline Sample & $\begin{array}{c}\text { Dry } \\
\text { Weight (A) }\end{array}$ & $\begin{array}{c}\text { Pycnometer+water } \\
(\mathrm{B})\end{array}$ & $\begin{array}{c}\text { SSD } \\
\text { Weight } \\
(\mathrm{S})\end{array}$ & $\begin{array}{c}\text { Sample+ } \\
\text { Water } \\
+ \text { Pycnometer } \\
(\mathrm{S})\end{array}$ & $\mathrm{G}_{\mathrm{sb}}$ & $\mathrm{G}_{\mathrm{sa}}$ & $\begin{array}{c}\% \\
\text { Absorption }\end{array}$ \\
\hline 1 & 492.6 & 666.9 & 500.6 & 977.7 & 2.595 & 2.710 & 1.624 \\
\hline 2 & 493.1 & 666.9 & 500.7 & 977.9 & 2.599 & 2.708 & 1.541 \\
\hline 3 & 492.5 & 666.8 & 499.9 & 977.6 & 2.604 & 2.711 & 1.503 \\
\hline 4 & 492.3 & 666.9 & 500.4 & 977.5 & 2.594 & 2.709 & 1.645 \\
\hline 5 & 493.4 & 666.8 & 501.3 & 978.0 & 2.595 & 2.708 & 1.601 \\
\hline
\end{tabular}

Provisional Cone Test

\begin{tabular}{|c|c|c|c|c|c|c|c|}
\hline Sample & $\begin{array}{c}\text { Dry } \\
\text { Weight (A) }\end{array}$ & $\begin{array}{c}\text { Pycnometer+water } \\
(\mathrm{B})\end{array}$ & $\begin{array}{c}\text { SSD } \\
\text { Weight } \\
(\mathrm{S})\end{array}$ & $\begin{array}{c}\text { Sample+ } \\
\text { Water } \\
+ \text { Pycnometer } \\
(\mathrm{S})\end{array}$ & $\mathrm{G}_{\mathrm{sb}}$ & $\mathrm{G}_{\mathrm{sa}}$ & $\begin{array}{c}\% \\
\text { Absorption }\end{array}$ \\
\hline 1 & 498.5 & 666.7 & 503.3 & 980.9 & 2.636 & 2.705 & 0.963 \\
\hline 2 & 493.5 & 666.7 & 498.4 & 978.1 & 2.639 & 2.710 & 0.993 \\
\hline 3 & 492.6 & 666.7 & 497.8 & 977.7 & 2.637 & 2.713 & 1.056 \\
\hline 4 & 495.4 & 666.8 & 500.2 & 979.2 & 2.638 & 2.707 & 0.969 \\
\hline 5 & 495.1 & 666.8 & 499.9 & 978.9 & 2.636 & 2.705 & 0.970 \\
\hline
\end{tabular}


Provisional Surface Test

\begin{tabular}{|c|c|c|c|c|c|c|c|}
\hline Sample & $\begin{array}{c}\text { Dry } \\
\text { Weight (A) }\end{array}$ & $\begin{array}{c}\text { Pycnometer+water } \\
(\mathrm{B})\end{array}$ & $\begin{array}{c}\text { SSD } \\
\text { Weight } \\
(\mathrm{S})\end{array}$ & $\begin{array}{c}\text { Sample+ } \\
\text { Water } \\
+ \text { Pycnometer } \\
(\mathrm{S})\end{array}$ & $\mathrm{G}_{\mathrm{sb}}$ & $\mathrm{G}_{\mathrm{sa}}$ & $\begin{array}{c}\% \\
\text { Absorption }\end{array}$ \\
\hline 1 & 495.5 & 666.8 & 501.4 & 979.4 & 2.624 & 2.709 & 1.191 \\
\hline 2 & 496.4 & 666.7 & 502.6 & 979.9 & 2.621 & 2.710 & 1.249 \\
\hline 3 & 492.6 & 666.7 & 498.5 & 978.0 & 2.631 & 2.717 & 1.198 \\
\hline 4 & 494.5 & 666.7 & 500.3 & 978.6 & 2.625 & 2.708 & 1.173 \\
\hline 5 & 494.0 & 666.8 & 499.7 & 978.4 & 2.626 & 2.708 & 1.154 \\
\hline
\end{tabular}

Hard Paper Method

\begin{tabular}{|c|c|c|c|c|c|c|c|}
\hline Sample & $\begin{array}{c}\text { Dry } \\
\text { Weight (A) }\end{array}$ & $\begin{array}{c}\text { Pycnometer+water } \\
(\mathrm{B})\end{array}$ & $\begin{array}{c}\text { SSD } \\
\text { Weight } \\
(\mathrm{S})\end{array}$ & $\begin{array}{c}\text { Sample+ } \\
\text { Water } \\
\text { +Pycnometer } \\
(\mathrm{S})\end{array}$ & $\mathrm{G}_{\mathrm{sb}}$ & $\mathrm{G}_{\mathrm{sa}}$ & $\begin{array}{c}\% \\
\text { Absorption }\end{array}$ \\
\hline 1 & 494.2 & 666.7 & 499.3 & 978.4 & 2.634 & 2.708 & 1.032 \\
\hline 2 & 493.6 & 666.7 & 498.5 & 978.1 & 2.638 & 2.709 & 0.993 \\
\hline 3 & 494.7 & 666.8 & 500.1 & 978.8 & 2.630 & 2.708 & 1.092 \\
\hline 4 & 495.6 & 666.8 & 501.6 & 979.6 & 2.625 & 2.711 & 1.211 \\
\hline 5 & 495.0 & 666.8 & 500.8 & 978.8 & 2.622 & 2.705 & 1.172 \\
\hline
\end{tabular}


Arizona DOT Method

\begin{tabular}{|c|c|c|c|c|c|c|c|}
\hline Sample & $\begin{array}{c}\text { Dry } \\
\text { Weight (A) }\end{array}$ & $\begin{array}{c}\text { Pycnometer+water } \\
(\mathrm{B})\end{array}$ & $\begin{array}{c}\text { SSD } \\
\text { Weight } \\
(\mathrm{S})\end{array}$ & $\begin{array}{c}\text { Sample+ } \\
\text { Water } \\
+ \text { Pycnometer } \\
(\mathrm{S})\end{array}$ & $\mathrm{G}_{\mathrm{sb}}$ & $\mathrm{G}_{\mathrm{sa}}$ & $\begin{array}{c}\% \\
\text { Absorption }\end{array}$ \\
\hline 1 & 493.3 & 666.8 & 499.9 & 978.0 & 2.614 & 2.709 & 1.338 \\
\hline 2 & 499.7 & 666.7 & 505.5 & 981.5 & 2.620 & 2.703 & 1.161 \\
\hline 3 & 494.8 & 666.7 & 501.3 & 978.9 & 2.617 & 2.710 & 1.314 \\
\hline 4 & 495.9 & 666.7 & 502.4 & 979.7 & 2.618 & 2.711 & 1.311 \\
\hline 5 & 494.0 & 666.8 & 500.1 & 978.3 & 2.619 & 2.707 & 1.235 \\
\hline
\end{tabular}

Wisconsin Method

\begin{tabular}{|c|c|c|c|c|c|c|c|}
\hline Sample & $\begin{array}{c}\text { Dry } \\
\text { Weight (A) }\end{array}$ & $\begin{array}{c}\text { Pycnometer+water } \\
(\mathrm{B})\end{array}$ & $\begin{array}{c}\text { SSD } \\
\text { Weight } \\
(\mathrm{S})\end{array}$ & $\begin{array}{c}\text { Sample+ } \\
\text { Water } \\
+ \text { Pycnometer } \\
(\mathrm{S})\end{array}$ & $\mathrm{G}_{\mathrm{sb}}$ & $\mathrm{G}_{\mathrm{sa}}$ & $\begin{array}{c}\% \\
\text { Absorption }\end{array}$ \\
\hline 1 & 497.3 & 664.3 & 499.8 & 978.1 & 2.674 & 2.710 & 0.503 \\
\hline 2 & 497.6 & 664.3 & 500.5 & 978.0 & 2.664 & 2.706 & 0.583 \\
\hline 3 & 498.0 & 666.7 & 501.2 & 980.8 & 2.662 & 2.708 & 0.643 \\
\hline 4 & 497.7 & 664.3 & 501.1 & 978.2 & 2.659 & 2.708 & 0.683 \\
\hline 5 & 499.2 & 666.7 & 502.6 & 981.2 & 2.654 & 2.703 & 0.681 \\
\hline
\end{tabular}




\section{CoreLok Method}

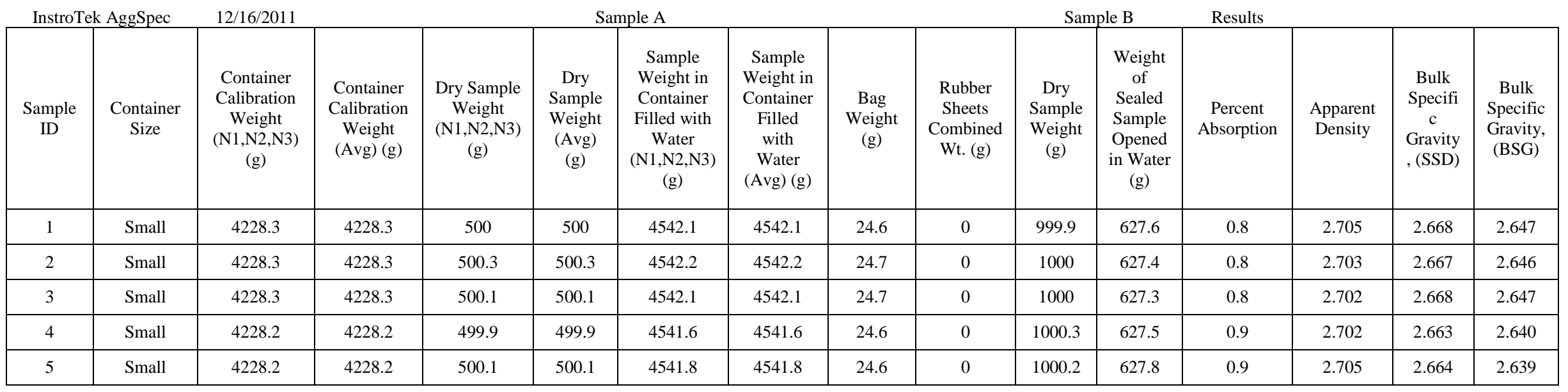

\section{Iowa Method}

\begin{tabular}{|c|c|c|c|c|c|c|c|c|c|c|c|c|}
\hline Sample & $\begin{array}{c}\text { Weight of } \\
\text { Pycnometer } \\
+ \text { Water } \\
\text { (W1) } \\
\text { gms }\end{array}$ & $\begin{array}{l}\text { Weight of } \\
\text { Dry Sample } \\
\text { (W) } \\
\text { gms }\end{array}$ & $\begin{array}{c}\text { Weight of } \\
\text { Pycnometer } \\
+ \text { Sample + } \\
\text { Water } \\
\text { (W2) } \\
\text { gms }\end{array}$ & $\begin{array}{c}\text { Temperature } \\
\text { of Water } \\
\left({ }^{\circ} \mathrm{C}\right)\end{array}$ & $\begin{array}{l}\text { Correction } \\
\text { Multiplier } \\
\text { (R) }\end{array}$ & $\begin{array}{c}\text { SSD } \\
\text { Weight } \\
\text { of } \\
\text { Coarse } \\
\text { Portion } \\
\text { (Wa) } \\
\text { gms }\end{array}$ & $\begin{array}{l}\text { SSD } \\
\text { Weight } \\
\text { of Fine } \\
\text { Portion } \\
\text { (Wb) } \\
\text { gms }\end{array}$ & $\begin{array}{l}\text { Combined } \\
\text { Dry } \\
\text { Weight of } \\
\text { Coarse and } \\
\text { Fine } \\
\text { Portion } \\
\text { (Wc) } \\
\text { gms }\end{array}$ & $\mathrm{G}_{\mathrm{sb}}$ & $\mathrm{G}_{\mathrm{sa}}$ & $\begin{array}{c}\% \\
\text { Absorption }\end{array}$ & ABS \\
\hline 1 & 7448.6 & 2091.1 & 8766.1 & 25 & 1.000 & 1196.4 & 509.3 & 1687.7 & 2.627 & 2.703 & 1.067 & 0.011 \\
\hline 2 & 7448.5 & 2081.2 & 8759.4 & 25 & 1.000 & 1268.5 & 491.1 & 1741.8 & 2.629 & 2.702 & 1.022 & 0.010 \\
\hline 3 & 7448.6 & 2096.8 & 8770.7 & 25 & 1.000 & 1275.6 & 478.3 & 1736.3 & 2.634 & 2.707 & 1.014 & 0.010 \\
\hline 4 & 7448.6 & 2088.3 & 8765.3 & 25 & 1.000 & 1229.8 & 508.2 & 1720.3 & 2.633 & 2.706 & 1.029 & 0.010 \\
\hline 5 & 7448.5 & 2100.6 & 8773.8 & 25 & 1.000 & 1282.7 & 498.3 & 1762.7 & 2.635 & 2.709 & 1.038 & 0.010 \\
\hline
\end{tabular}


Texas Method

\begin{tabular}{|c|c|c|c|c|c|c|c|c|c|c|c|c|c|c|c|c|}
\hline $\begin{array}{c}\text { Sample } \\
\text { (Retained } \\
\text { on \# } 80 \\
\text { Sieve) }\end{array}$ & $\begin{array}{l}\text { Weight } \\
\text { of } \\
\text { Oven } \\
\text { dry } \\
\text { Sample } \\
\text { (X1) } \\
\text { gms }\end{array}$ & $\begin{array}{c}\text { Weight } \\
\text { of SSD } \\
\text { Sample } \\
\text { (X) } \\
\text { gms }\end{array}$ & $\begin{array}{l}\text { Weight of } \\
\text { Pycnometer } \\
\text { + Water } \\
\text { (Y) gms }\end{array}$ & $\begin{array}{c}\text { Weight of } \\
\text { Pycnometer } \\
+ \text { Sample + } \\
\text { Water } \\
\text { (Z) gms }\end{array}$ & $\mathrm{G}_{\mathrm{sb}}$ & $\mathrm{G}_{\mathrm{sa}}$ & $\begin{array}{c}\text { Sample } \\
\text { (Passing } \\
\text { \# } 80 \\
\text { Sieve) }\end{array}$ & $\begin{array}{c}\text { Dry } \\
\text { Weight }\end{array}$ & $\begin{array}{l}\text { Weight of } \\
\text { Pycnometer } \\
\text { + Water }\end{array}$ & $\begin{array}{l}\text { Weight of } \\
\text { Sample + } \\
\text { Pycnometer } \\
\text { + Water }\end{array}$ & $\begin{array}{c}\mathrm{G}_{\mathrm{sb}} \\
\text { or } \\
\mathrm{G}_{\mathrm{sa}}\end{array}$ & $\begin{array}{l}\text { Percent } \\
\text { of } \\
\text { material } \\
\text { No. 1 } \\
\text { (W1) }\end{array}$ & $\begin{array}{l}\text { Percent } \\
\text { of } \\
\text { material } \\
\text { No. } 2 \\
\text { (W2) }\end{array}$ & $\begin{array}{l}\text { Average } \\
\text { Bulk } \\
\text { Specific } \\
\text { Gravity }\end{array}$ & $\begin{array}{l}\text { Average } \\
\text { Apparent } \\
\text { Specific } \\
\text { Gravity }\end{array}$ & $\begin{array}{c}\% \\
\text { Absorption }\end{array}$ \\
\hline 1 & 1287.6 & 1301.7 & 5660.9 & 6472.5 & 2.627 & 2.705 & 1 & 150.2 & 666.6 & 761.9 & 2.736 & 90 & 10 & 2.638 & 2.708 & 1.095 \\
\hline 2 & 1289.1 & 1303.7 & 5660.9 & 6474.2 & 2.629 & 2.709 & 2 & 145.8 & 666.6 & 759.2 & 2.741 & 90 & 10 & 2.640 & 2.712 & 1.133 \\
\hline 3 & 1290.9 & 1305.6 & 5660.8 & 6475.9 & 2.632 & 2.713 & 3 & 142.5 & 666.6 & 756.8 & 2.725 & 90 & 10 & 2.641 & 2.714 & 1.139 \\
\hline 4 & 1286.4 & 1298.3 & 5660.9 & 6471.4 & 2.637 & 2.703 & 4 & 152.6 & 666.6 & 763.1 & 2.720 & 89 & 11 & 2.646 & 2.705 & 0.925 \\
\hline 5 & 1283.1 & 1295.6 & 5661.0 & 6469.2 & 2.633 & 2.702 & 5 & 155.4 & 666.6 & 765.6 & 2.755 & 89 & 11 & 2.645 & 2.708 & 0.974 \\
\hline
\end{tabular}

California Test 225

\begin{tabular}{|c|c|c|c|c|c|c|c|c|c|c|}
\hline Sample & $\begin{array}{c}\text { Mass of } \\
\text { Empty } \\
\text { Pail (M1) } \\
\text { gms }\end{array}$ & $\begin{array}{c}\text { Mass of } \\
\text { Empty } \\
\text { Pail in } \\
\text { Water } \\
\text { (M2) } \\
\text { gms }\end{array}$ & $\begin{array}{c}\text { Mass of } \\
\text { Dry Pail } \\
\text { and SSD } \\
\text { Sample } \\
\text { (M3) } \\
\text { gms }\end{array}$ & $\begin{array}{c}\text { Mass of } \\
\text { Pail + } \\
\text { Sample in } \\
\text { Water } \\
\text { (M4) } \\
\text { gms }\end{array}$ & $\begin{array}{c}\text { Mass of } \\
\text { Dry } \\
\text { Sample } \\
\text { (M5) } \\
\text { gms }\end{array}$ & $\begin{array}{c}\text { Mass of } \\
\text { Sample } \\
\text { in Water } \\
(\mathrm{Mw}) \\
\text { gms }\end{array}$ & $\begin{array}{l}\text { Mass of } \\
\text { SSD } \\
\text { Sample } \\
\text { in Air } \\
\text { (Ma) gms }\end{array}$ & $\mathrm{G}_{\mathrm{sb}}$ & $\mathrm{G}_{\mathrm{sa}}$ & $\begin{array}{c}\% \\
\text { Absorption }\end{array}$ \\
\hline 1 & 2059.7 & 1314.8 & 3061.7 & 1940.1 & 991.1 & 625.3 & 1002.0 & 2.631 & 2.709 & 1.100 \\
\hline 2 & 2059.8 & 1314.8 & 3062.4 & 1940.8 & 991.5 & 626 & 1002.6 & 2.633 & 2.713 & 1.120 \\
\hline 3 & 2059.8 & 1314.8 & 3065.3 & 1942.3 & 994.2 & 627.5 & 1005.5 & 2.630 & 2.711 & 1.137 \\
\hline 4 & 2059.7 & 1314.8 & 3058.5 & 1938.9 & 988.3 & 624.1 & 998.8 & 2.638 & 2.714 & 1.062 \\
\hline 5 & 2059.8 & 1314.8 & 3060.1 & 1939.5 & 989.7 & 624.7 & 1000.3 & 2.635 & 2.712 & 1.071 \\
\hline
\end{tabular}




\section{Slag Fine Aggregates}

Standard AASHTO T 84

\begin{tabular}{|c|c|c|c|c|c|c|c|}
\hline Sample & $\begin{array}{c}\text { Dry } \\
\text { Weight } \\
\text { (A) }\end{array}$ & $\begin{array}{c}\text { Pycnometer + } \\
\text { water (B) }\end{array}$ & $\begin{array}{c}\text { SSD } \\
\text { Weight } \\
(\mathrm{S})\end{array}$ & $\begin{array}{c}\text { Sample + } \\
\text { Water + } \\
\text { Pycnometer } \\
(\mathrm{C})\end{array}$ & $\mathrm{G}_{\mathrm{sb}}$ & $\mathrm{G}_{\mathrm{sa}}$ & $\begin{array}{c}\% \\
\text { Absorption }\end{array}$ \\
\hline 1 & 490.1 & 666.6 & 500.5 & 977.8 & 2.589 & 2.740 & 2.122 \\
\hline 2 & 489.7 & 664.4 & 500.8 & 975.1 & 2.576 & 2.735 & 2.267 \\
\hline 3 & 492.2 & 666.7 & 503.6 & 979.6 & 2.581 & 2.745 & 2.316 \\
\hline 4 & 488.3 & 666.7 & 499.1 & 976.5 & 2.580 & 2.736 & 2.212 \\
\hline 5 & 493.9 & 664.4 & 505.4 & 978.6 & 2.583 & 2.748 & 2.328 \\
\hline
\end{tabular}

Provisional Cone Test

\begin{tabular}{|c|c|c|c|c|c|c|c|}
\hline Sample & $\begin{array}{c}\text { Dry } \\
\text { Weight } \\
\text { (A) }\end{array}$ & $\begin{array}{c}\text { Pycnometer }+ \\
\text { water (B) }\end{array}$ & $\begin{array}{c}\text { SSD } \\
\text { Weight } \\
(\mathrm{S})\end{array}$ & $\begin{array}{c}\text { Sample + } \\
\text { Water + } \\
\text { Pycnometer } \\
(\mathrm{C})\end{array}$ & $\mathrm{G}_{\mathrm{sb}}$ & $\mathrm{G}_{\mathrm{sa}}$ & $\begin{array}{c}\% \\
\text { Absorption }\end{array}$ \\
\hline 1 & 495.4 & 666.5 & 506.9 & 981.2 & 2.578 & 2.741 & 2.315 \\
\hline 2 & 488.9 & 664.5 & 499.4 & 974.7 & 2.584 & 2.736 & 2.148 \\
\hline 3 & 489.6 & 666.6 & 500.3 & 977.7 & 2.588 & 2.743 & 2.185 \\
\hline 4 & 492.1 & 664.4 & 502.1 & 976.4 & 2.589 & 2.732 & 2.032 \\
\hline 5 & 489.3 & 664.4 & 500.0 & 975.5 & 2.590 & 2.746 & 2.187 \\
\hline
\end{tabular}


Provisional Surface Test

\begin{tabular}{|c|c|c|c|c|c|c|c|}
\hline Sample & $\begin{array}{c}\text { Dry } \\
\text { Weight } \\
(\mathrm{A})\end{array}$ & $\begin{array}{c}\text { Pycnometer }+ \\
\text { water (B) }\end{array}$ & $\begin{array}{c}\text { SSD } \\
\text { Weight } \\
(\mathrm{S})\end{array}$ & $\begin{array}{c}\text { Sample + } \\
\text { Water + } \\
\text { Pycnometer } \\
(\mathrm{C})\end{array}$ & $\mathrm{G}_{\mathrm{sb}}$ & $\mathrm{G}_{\mathrm{sa}}$ & $\begin{array}{c}\% \\
\text { Absorption }\end{array}$ \\
\hline 1 & 488.3 & 666.6 & 499.8 & 976.9 & 2.577 & 2.743 & 2.355 \\
\hline 2 & 489.2 & 664.5 & 500.2 & 975.5 & 2.586 & 2.745 & 2.249 \\
\hline 3 & 491.1 & 664.5 & 502.9 & 976.5 & 2.573 & 2.742 & 2.403 \\
\hline 4 & 487.7 & 666.7 & 498.8 & 976.3 & 2.578 & 2.738 & 2.276 \\
\hline 5 & 490.2 & 666.7 & 501.3 & 978.1 & 2.581 & 2.742 & 2.264 \\
\hline
\end{tabular}

Hard Paper Method

\begin{tabular}{|c|c|c|c|c|c|c|c|}
\hline Sample & $\begin{array}{c}\text { Dry } \\
\text { Weight } \\
\text { (A) }\end{array}$ & $\begin{array}{c}\text { Pycnometer + } \\
\text { water (B) }\end{array}$ & $\begin{array}{c}\text { SSD } \\
\text { Weight } \\
(\mathrm{S})\end{array}$ & $\begin{array}{c}\text { Sample + } \\
\text { Water + } \\
\text { Pycnometer } \\
(\mathrm{C})\end{array}$ & $\mathrm{G}_{\mathrm{sb}}$ & $\mathrm{G}_{\mathrm{sa}}$ & $\begin{array}{c}\% \\
\text { Absorption }\end{array}$ \\
\hline 1 & 491.6 & 666.7 & 502.4 & 978.9 & 2.585 & 2.740 & 2.197 \\
\hline 2 & 490.5 & 664.4 & 501.6 & 976.2 & 2.584 & 2.745 & 2.263 \\
\hline 3 & 492.3 & 666.7 & 503.6 & 979.1 & 2.575 & 2.737 & 2.295 \\
\hline 4 & 489.6 & 664.4 & 500.7 & 975.3 & 2.580 & 2.740 & 2.267 \\
\hline 5 & 488.1 & 666.7 & 498.5 & 976.5 & 2.587 & 2.738 & 2.131 \\
\hline
\end{tabular}


Arizona DOT Method

\begin{tabular}{|c|c|c|c|c|c|c|c|}
\hline Sample & $\begin{array}{c}\text { Dry } \\
\text { Weight } \\
(\mathrm{A})\end{array}$ & $\begin{array}{c}\text { Pycnometer }+ \\
\text { water (B) }\end{array}$ & $\begin{array}{c}\text { SSD } \\
\text { Weight } \\
(\mathrm{S})\end{array}$ & $\begin{array}{c}\text { Sample + } \\
\text { Water }+ \\
\text { Pycnometer } \\
(\mathrm{C})\end{array}$ & $\mathrm{G}_{\mathrm{sb}}$ & $\mathrm{G}_{\mathrm{sa}}$ & $\begin{array}{c}\% \\
\text { Absorption }\end{array}$ \\
\hline 1 & 490.1 & 666.6 & 500.5 & 977.9 & 2.590 & 2.741 & 2.122 \\
\hline 2 & 491.4 & 664.5 & 502.4 & 976.6 & 2.582 & 2.741 & 2.239 \\
\hline 3 & 489.8 & 666.6 & 499.6 & 977.4 & 2.594 & 2.736 & 2.001 \\
\hline 4 & 490.6 & 666.6 & 501.5 & 978.5 & 2.588 & 2.745 & 2.222 \\
\hline 5 & 490.2 & 664.4 & 500.5 & 975.7 & 2.591 & 2.740 & 2.101 \\
\hline
\end{tabular}

Wisconsin Method

\begin{tabular}{|c|c|c|c|c|c|c|c|}
\hline Sample & $\begin{array}{c}\text { Dry } \\
\text { Weight } \\
\text { (A) }\end{array}$ & $\begin{array}{c}\text { Pycnometer }+ \\
\text { water (B) }\end{array}$ & $\begin{array}{c}\text { SSD } \\
\text { Weight } \\
(\mathrm{S})\end{array}$ & $\begin{array}{c}\text { Sample }+ \\
\text { Water }+ \\
\text { Pycnometer } \\
(\mathrm{C})\end{array}$ & $\mathrm{G}_{\mathrm{sb}}$ & $\mathrm{G}_{\mathrm{sa}}$ & $\begin{array}{c}\% \\
\text { Absorption }\end{array}$ \\
\hline 1 & 492.4 & 666.6 & 498.3 & 979.5 & 2.656 & 2.743 & 1.198 \\
\hline 2 & 494.6 & 664.4 & 500.5 & 978.2 & 2.649 & 2.736 & 1.193 \\
\hline 3 & 496.4 & 666.6 & 502.9 & 981.9 & 2.646 & 2.741 & 1.309 \\
\hline 4 & 498.8 & 664.4 & 506.0 & 981.5 & 2.641 & 2.745 & 1.443 \\
\hline 5 & 493.3 & 666.6 & 499.8 & 980.2 & 2.649 & 2.745 & 1.318 \\
\hline
\end{tabular}




\section{CoreLok Method (Slag)}

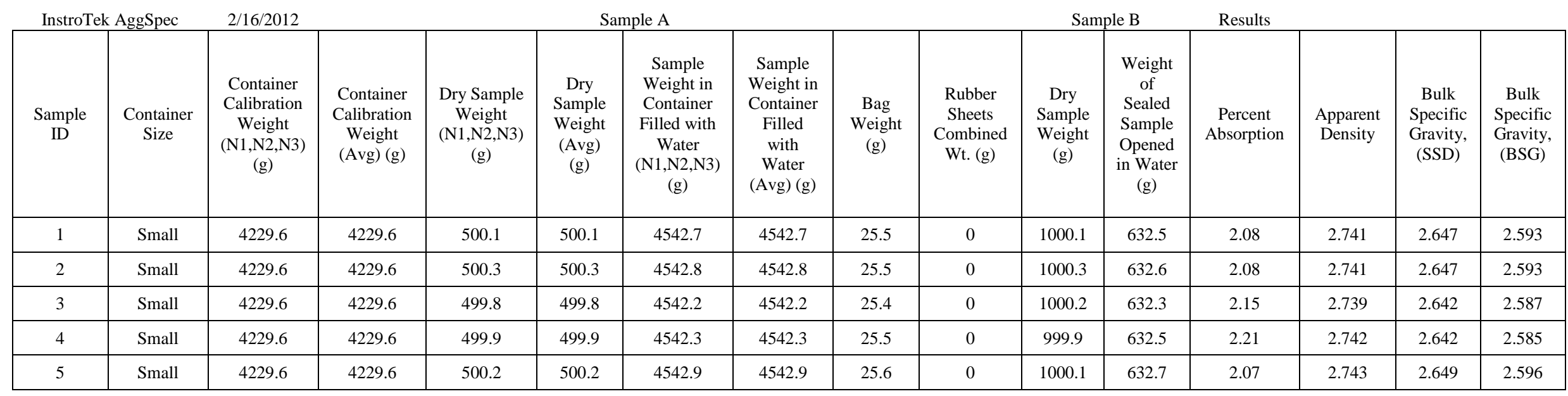

\section{Iowa Method}

\begin{tabular}{|c|c|c|c|c|c|c|c|c|c|c|c|c|}
\hline Sample & $\begin{array}{c}\text { Weight of } \\
\text { Pycnometer } \\
+ \text { Water } \\
\text { (W1) } \\
\text { gms }\end{array}$ & $\begin{array}{l}\text { Weight } \\
\text { of Dry } \\
\text { Sample } \\
\text { (W) } \\
\text { gms }\end{array}$ & $\begin{array}{l}\text { Weight of } \\
\text { Pycnometer+ } \\
\text { Sample+ } \\
\text { Water } \\
\text { (W2) } \\
\text { gms }\end{array}$ & $\begin{array}{c}\text { Temperature } \\
\text { of Water } \\
\left({ }^{\circ} \mathrm{C}\right)\end{array}$ & $\begin{array}{l}\text { Correction } \\
\text { Multiplier } \\
\text { ( R ) }\end{array}$ & $\begin{array}{l}\text { SSD } \\
\text { Weight } \\
\text { of } \\
\text { Coarse } \\
\text { Portion } \\
\text { (Wa) } \\
\text { gms }\end{array}$ & $\begin{array}{l}\text { SSD } \\
\text { Weight } \\
\text { of Fine } \\
\text { Portion } \\
\text { (Wb) } \\
\text { gms }\end{array}$ & $\begin{array}{c}\text { Combined } \\
\text { Dry } \\
\text { Weight of } \\
\text { Coarse } \\
\text { and Fine } \\
\text { Portion } \\
\text { (Wc) } \\
\text { gms }\end{array}$ & $\mathrm{G}_{\mathrm{sb}}$ & $\mathrm{G}_{\mathrm{sa}}$ & $\begin{array}{c}\% \\
\text { Absorption }\end{array}$ & ABS \\
\hline 1 & 7581.9 & 2203.6 & 8980.9 & 25 & 1.000 & 1693.3 & 0.0 & 1663.1 & 2.609 & 2.739 & 1.816 & 0.018 \\
\hline 2 & 7581.9 & 2213.9 & 8988.6 & 25 & 1.000 & 1705.4 & 0.0 & 1675.3 & 2.614 & 2.743 & 1.797 & 0.018 \\
\hline 3 & 7581.9 & 2194.8 & 8975.5 & 25 & 1.000 & 1680.5 & 0 & 1652.2 & 2.617 & 2.739 & 1.713 & 0.017 \\
\hline 4 & 7581.9 & 2207.6 & 8983.4 & 25 & 1.000 & 1685.4 & 0 & 1657.6 & 2.618 & 2.739 & 1.677 & 0.017 \\
\hline 5 & 7581.9 & 2220.3 & 8993.2 & 25 & 1.000 & 1709.6 & 0 & 1678.4 & 2.611 & 2.744 & 1.859 & 0.019 \\
\hline
\end{tabular}




\section{Texas Method}

\begin{tabular}{|c|c|c|c|c|c|c|c|c|c|c|c|c|c|c|c|c|}
\hline $\begin{array}{c}\text { Sample } \\
\text { (Retained } \\
\text { on \# } 80 \\
\text { Sieve) }\end{array}$ & $\begin{array}{c}\text { Weight } \\
\text { of Oven } \\
\text { dry } \\
\text { Sample } \\
\text { (X1) } \\
\text { gms }\end{array}$ & $\begin{array}{l}\text { Weight } \\
\text { of SSD } \\
\text { Sample } \\
\text { (X) gms }\end{array}$ & $\begin{array}{l}\text { Weight of } \\
\text { Pycnometer } \\
\text { + Water } \\
\text { (Y) gms }\end{array}$ & $\begin{array}{c}\text { Weight of } \\
\text { Pycnometer } \\
+ \text { Sample + } \\
\text { Water } \\
\text { (Z) gms }\end{array}$ & $\mathrm{G}_{\mathrm{sb}}$ & $\mathrm{G}_{\mathrm{sa}}$ & $\begin{array}{c}\text { Sample } \\
\text { (Passing } \\
\# 80 \\
\text { Sieve) }\end{array}$ & $\begin{array}{c}\text { Dry } \\
\text { Weight }\end{array}$ & $\begin{array}{l}\text { Weight of } \\
\text { Pycnometer } \\
\text { + Water }\end{array}$ & $\begin{array}{l}\text { Weight of } \\
\text { Sample + } \\
\text { Pycnometer } \\
\text { + Water }\end{array}$ & $\begin{array}{c}\mathrm{G}_{\mathrm{sb}} \text { or } \\
\mathrm{G}_{\mathrm{sa}}\end{array}$ & $\begin{array}{c}\begin{array}{c}\text { Percent } \\
\text { of }\end{array} \\
\text { material } \\
\text { No. } 1 \\
\text { (W1) }\end{array}$ & $\begin{array}{l}\text { Percent } \\
\text { of } \\
\text { material } \\
\text { No. } 2 \\
\text { (W2) }\end{array}$ & $\begin{array}{l}\text { Average } \\
\text { Bulk } \\
\text { Specific } \\
\text { Gravity }\end{array}$ & $\begin{array}{c}\text { Average } \\
\text { Apparent } \\
\text { Specific } \\
\text { Gravity }\end{array}$ & $\begin{array}{c}\% \\
\text { Absorption }\end{array}$ \\
\hline 1 & 1274.3 & 1293.8 & 7576.7 & 8385.5 & 2.627 & 2.737 & 1 & 118.4 & 666.6 & 742.1 & 2.760 & 91 & 9 & 2.638 & 2.739 & 1.53 \\
\hline 2 & 1284.1 & 1303.1 & 7576.7 & 8391.6 & 2.630 & 2.737 & 2 & 125.3 & 666.6 & 746.4 & 2.754 & 91 & 9 & 2.641 & 2.738 & 1.48 \\
\hline 3 & 1289.9 & 1308.5 & 7576.7 & 8395.5 & 2.634 & 2.738 & 3 & 122.7 & 666.6 & 744.8 & 2.757 & 91 & 9 & 2.644 & 2.740 & 1.44 \\
\hline 4 & 1266.4 & 1286.8 & 7576.7 & 8381.7 & 2.628 & 2.745 & 4 & 132.6 & 666.6 & 751.1 & 2.757 & 91 & 9 & 2.640 & 2.746 & 1.61 \\
\hline 5 & 1281.6 & 1299.1 & 7576.7 & 8389.9 & 2.638 & 2.736 & 5 & 115.8 & 666.6 & 740.6 & 2.770 & 92 & 8 & 2.648 & 2.739 & 1.37 \\
\hline
\end{tabular}

California Test 225

\begin{tabular}{|c|c|c|c|c|c|c|c|c|c|c|}
\hline Sample & $\begin{array}{c}\text { Mass of } \\
\text { Empty } \\
\text { Pail } \\
\text { (M1) } \\
\text { gms }\end{array}$ & $\begin{array}{c}\text { Mass } \\
\text { of } \\
\text { Empty } \\
\text { Pail in } \\
\text { Water } \\
\text { (M2) } \\
\text { gms }\end{array}$ & $\begin{array}{c}\text { Mass } \\
\text { of Dry } \\
\text { Pail } \\
\text { and } \\
\text { SSD } \\
\text { Sample } \\
\text { (M3) } \\
\text { gms }\end{array}$ & $\begin{array}{c}\text { Mass } \\
\text { of Pail } \\
+ \\
\text { Sample } \\
\text { in } \\
\text { Water } \\
\text { (M4) } \\
\text { gms } \\
\end{array}$ & $\begin{array}{c}\text { Mass } \\
\text { of Dry } \\
\text { Sample } \\
\text { (M5) } \\
\text { gms }\end{array}$ & $\begin{array}{c}\text { Mass } \\
\text { of } \\
\text { Sample } \\
\text { in } \\
\text { Water } \\
(\mathrm{Mw}) \\
\text { gms }\end{array}$ & $\begin{array}{c}\text { Mass } \\
\text { of SSD } \\
\text { Sample } \\
\text { in Air } \\
\text { (Ma) } \\
\text { gms }\end{array}$ & $\mathrm{G}_{\mathrm{sb}}$ & $\mathrm{G}_{\mathrm{sa}}$ & $\begin{array}{c}\% \\
\text { Absorption }\end{array}$ \\
\hline 1 & 2387.2 & 1503.3 & 2883.9 & 1812.9 & 487.4 & 309.6 & 496.7 & 2.605 & 2.741 & 1.908 \\
\hline 2 & 2387.2 & 1503.3 & 2888.2 & 1814.9 & 490.9 & 311.6 & 501.0 & 2.592 & 2.738 & 2.057 \\
\hline 3 & 2387.2 & 1503.3 & 2889.3 & 1815.6 & 491.7 & 312.3 & 502.1 & 2.591 & 2.741 & 2.115 \\
\hline 4 & 2387.2 & 1503.3 & 2890.1 & 1816.1 & 492.3 & 312.8 & 502.9 & 2.590 & 2.743 & 2.153 \\
\hline 5 & 2387.2 & 1503.3 & 2886.4 & 1814.2 & 489.4 & 310.9 & 499.2 & 2.599 & 2.742 & 2.002 \\
\hline
\end{tabular}




\section{Coarse aggregates}

Standard AASHTO T 84

\begin{tabular}{|c|c|c|c|c|c|c|c|}
\hline $\begin{array}{c}\text { Aggregate } \\
\text { Size }\end{array}$ & $\begin{array}{c}\text { Test } \\
\text { Method }\end{array}$ & $\begin{array}{c}\mathrm{A} \\
(\mathrm{gms})\end{array}$ & $\begin{array}{c}\mathrm{B} \\
(\mathrm{gms})\end{array}$ & $\begin{array}{c}\mathrm{C} \\
(\mathrm{gms})\end{array}$ & $\mathrm{G}_{\mathrm{sb}}$ & $\mathrm{G}_{\mathrm{sa}}$ & $\begin{array}{c}\% \\
\text { Absorption }\end{array}$ \\
\hline $\begin{array}{c}\text { No. 8 } \\
\text { Regular }\end{array}$ & $\begin{array}{c}\text { AASHTO } \\
\text { T 85 }\end{array}$ & 2047.5 & 2062.8 & 1288.0 & 2.643 & 2.696 & 0.75 \\
\hline $\begin{array}{c}\text { No. 8 } \\
\text { Regular }\end{array}$ & $\begin{array}{c}\text { AASHTO } \\
\text { T 85 }\end{array}$ & 1994.8 & 2008.9 & 1254.2 & 2.643 & 2.693 & 0.71 \\
\hline $\begin{array}{c}\text { No. 8 } \\
\text { Regular }\end{array}$ & $\begin{array}{c}\text { AASHTO } \\
\text { T 85 }\end{array}$ & 2032.6 & 2046.9 & 1277.4 & 2.641 & 2.691 & 0.70 \\
\hline $\begin{array}{c}\text { No. 8 } \\
\text { Regular }\end{array}$ & $\begin{array}{c}\text { AASHTO } \\
\text { T 85 }\end{array}$ & 2015.3 & 2029.7 & 1266.3 & 2.640 & 2.691 & 0.71 \\
\hline $\begin{array}{c}\text { No. 8 } \\
\text { Regular }\end{array}$ & $\begin{array}{c}\text { AASHTO } \\
\text { T 85 }\end{array}$ & 2022.4 & 2037.5 & 1271.9 & 2.642 & 2.695 & 0.75 \\
\hline $\begin{array}{c}\text { Aggregate } \\
\text { Size }\end{array}$ & $\begin{array}{c}\text { Test } \\
\text { Method }\end{array}$ & $\begin{array}{c}\text { A }(\mathrm{gms}) \\
(\mathrm{gms})\end{array}$ & $\begin{array}{c}\mathrm{C} \\
(\mathrm{gms})\end{array}$ & $\mathrm{G}_{\mathrm{sb}}$ & $\mathrm{G}_{\mathrm{sa}}$ & Absorption \\
\hline $\begin{array}{c}\text { No. 8 } \\
\text { Skid }\end{array}$ & $\begin{array}{c}\text { AASHTO } \\
\text { T 85 }\end{array}$ & 2050.2 & 2065.9 & 1290.9 & 2.645 & 2.700 & 0.77 \\
\hline $\begin{array}{c}\text { No. 8 } \\
\text { Skid }\end{array}$ & $\begin{array}{c}\text { AASHTO } \\
\text { T 85 }\end{array}$ & 2011.6 & 2026.7 & 1265.9 & 2.644 & 2.698 & 0.75 \\
\hline $\begin{array}{c}\text { No. 8 } \\
\text { Skid }\end{array}$ & $\begin{array}{c}\text { AASHTO } \\
\text { T 85 }\end{array}$ & 2028.4 & 2043.6 & 1277.6 & 2.648 & 2.702 & 0.75 \\
\hline $\begin{array}{c}\text { No. 8 } \\
\text { Skid }\end{array}$ & $\begin{array}{c}\text { AASHTO } \\
\text { T 85 }\end{array}$ & 2035.8 & 2051.3 & 1282.3 & 2.647 & 2.702 & 0.76 \\
\hline $\begin{array}{c}\text { No. 8 } \\
\text { Skid }\end{array}$ & $\begin{array}{c}\text { AASHTO } 85 \\
\text { TASO }\end{array}$ & 2004.5 & 2018.8 & 1260.8 & 2.644 & 2.695 & 0.71 \\
\hline
\end{tabular}




\begin{tabular}{|c|c|c|c|c|c|c|c|}
\hline $\begin{array}{c}\text { Aggregate } \\
\text { Size }\end{array}$ & $\begin{array}{c}\text { Test } \\
\text { Method }\end{array}$ & A (gms) & B (gms) & $\mathrm{C}(\mathrm{gms})$ & $\mathrm{G}_{\mathrm{sb}}$ & $\mathrm{G}_{\mathrm{sa}}$ & $\begin{array}{c}\% \\
\text { Absorption }\end{array}$ \\
\hline No. 9 & $\begin{array}{c}\text { AASHTO } \\
\text { T } 85\end{array}$ & 2163.3 & 2180.7 & 1357.0 & 2.626 & 2.683 & 0.80 \\
\hline No. 9 & $\begin{array}{c}\text { AASHTO } \\
\text { T } 85\end{array}$ & 2042.5 & 2057.9 & 1281.6 & 2.631 & 2.684 & 0.75 \\
\hline No. 9 & $\begin{array}{c}\text { AASHTO } \\
\text { T } 85\end{array}$ & 2032.8 & 2047.6 & 1274.8 & 2.630 & 2.682 & 0.73 \\
\hline No. 9 & $\begin{array}{c}\text { AASHTO } \\
\text { T } 85\end{array}$ & 2007.6 & 2023.3 & 1260.5 & 2.632 & 2.687 & 0.78 \\
\hline No. 9 & $\begin{array}{c}\text { AASHTO } \\
\text { T } 85\end{array}$ & 2058.3 & 2073.4 & 1290.3 & 2.628 & 2.680 & 0.73 \\
\hline $\begin{array}{l}\text { Aggregate } \\
\text { Size }\end{array}$ & $\begin{array}{c}\text { Test } \\
\text { Method }\end{array}$ & $\mathrm{A}(\mathrm{gms})$ & B (gms) & $\mathrm{C}(\mathrm{gms})$ & $\mathrm{G}_{\mathrm{sb}}$ & $\mathrm{G}_{\mathrm{sa}}$ & $\begin{array}{c}\% \\
\text { Absorption }\end{array}$ \\
\hline No. 67 & $\begin{array}{c}\text { AASHTO } \\
\text { T } 85 \\
\end{array}$ & 2052.8 & 2066.6 & 1290.7 & 2.646 & 2.694 & 0.67 \\
\hline No. 67 & $\begin{array}{c}\text { AASHTO } \\
\text { T } 85\end{array}$ & 2025.3 & 2039.5 & 1274.3 & 2.647 & 2.697 & 0.70 \\
\hline No. 67 & $\begin{array}{c}\text { AASHTO } \\
\text { T } 85\end{array}$ & 2002.5 & 2016.9 & 1259.6 & 2.644 & 2.696 & 0.72 \\
\hline No. 67 & $\begin{array}{c}\text { AASHTO } \\
\text { T } 85\end{array}$ & 2015.2 & 2029.0 & 1267.5 & 2.646 & 2.695 & 0.68 \\
\hline No. 67 & $\begin{array}{c}\text { AASHTO } \\
\text { T } 85\end{array}$ & 2048.4 & 2062.1 & 1288.9 & 2.649 & 2.697 & 0.67 \\
\hline
\end{tabular}




\section{CoreLok Method (\# 8 Regular)}

\begin{tabular}{|c|c|c|c|c|c|c|c|c|c|c|c|c|c|c|c|}
\hline InstroTek A & Spec & $3 / 7 / 2012$ & & & Sample A & & & & & Sample B & & Results & & & \\
\hline Sample ID & $\begin{array}{l}\text { Container } \\
\text { Size }\end{array}$ & $\begin{array}{l}\text { Container } \\
\text { Calibration } \\
\text { Weight } \\
\text { (N1,N2,N3) } \\
\text { (g) }\end{array}$ & $\begin{array}{l}\text { Container } \\
\text { Calibration } \\
\text { Weight } \\
\text { (Avg) (g) }\end{array}$ & $\begin{array}{l}\text { Dry } \\
\text { Sample } \\
\text { Weight } \\
\text { (N1,N2,N3) } \\
\text { (g) }\end{array}$ & $\begin{array}{l}\text { Dry } \\
\text { Sample } \\
\text { Weight } \\
\text { (Avg) (g) }\end{array}$ & $\begin{array}{l}\text { Sample } \\
\text { Weight in } \\
\text { Container } \\
\text { Filled with } \\
\text { Water } \\
\text { (N1,N2,N3) } \\
\text { (g) }\end{array}$ & $\begin{array}{l}\text { Sample } \\
\text { Weight in } \\
\text { Container } \\
\text { Filled with } \\
\text { Water } \\
\text { (Avg) (g) }\end{array}$ & $\begin{array}{l}\text { Bag } \\
\text { Weight (g) }\end{array}$ & $\begin{array}{l}\text { Rubber } \\
\text { Sheets } \\
\text { Combined } \\
\text { Wt. (g) }\end{array}$ & $\begin{array}{l}\text { Dry } \\
\text { Sample } \\
\text { Weight (g) }\end{array}$ & $\begin{array}{l}\text { Weight of } \\
\text { Sealed } \\
\text { Sample } \\
\text { Opened in } \\
\text { Water (g) }\end{array}$ & $\begin{array}{l}\text { Percent } \\
\text { Absorption }\end{array}$ & $\begin{array}{l}\text { Apparent } \\
\text { Density }\end{array}$ & $\begin{array}{l}\text { Bulk } \\
\text { Specific } \\
\text { Gravity, } \\
\text { (SSD) }\end{array}$ & $\begin{array}{l}\text { Bulk } \\
\text { Specific } \\
\text { Gravity, } \\
\text { (BSG) }\end{array}$ \\
\hline 1 & Large & 5658.2 & 5658.2 & 1000.1 & 1000.1 & 6280.3 & 6280.3 & 72.8 & 208.2 & 2000.2 & 1295.8 & 0.35 & 2.670 & 2.655 & 2.646 \\
\hline 2 & Large & 5658.2 & 5658.2 & 1000.3 & 1000.3 & 6280.7 & 6280.7 & 72.7 & 208.2 & 2000 & 1295.4 & 0.30 & 2.669 & 2.656 & 2.648 \\
\hline 3 & Large & 5658.2 & 5658.2 & 999.9 & 999.9 & 6280 & 6280 & 72.9 & 208.2 & 2000.4 & 1296.1 & 0.37 & 2.671 & 2.654 & 2.645 \\
\hline 4 & Large & 5658.2 & 5658.2 & 1000.4 & 1000.4 & 6280.6 & 6280.6 & 72.8 & 208.2 & 2000.3 & 1295.6 & 0.32 & 2.669 & 2.655 & 2.647 \\
\hline 5 & Large & 5658.2 & 5658.2 & 1000 & 1000 & 6280.2 & 6280.2 & 72.8 & 208.2 & 2000.1 & 1295.8 & 0.35 & 2.671 & 2.655 & 2.646 \\
\hline
\end{tabular}

\section{CoreLok Method (\# 8 Skid)}

\begin{tabular}{|c|c|c|c|c|c|c|c|c|c|c|c|c|c|c|c|}
\hline InstroTek A & sSpec & $3 / 7 / 2012$ & & & Sample A & & & & & Sample B & & Results & & & \\
\hline Sample ID & $\begin{array}{l}\text { Container } \\
\text { Size }\end{array}$ & $\begin{array}{l}\text { Container } \\
\text { Calibration } \\
\text { Weight } \\
\text { (N1,N2,N3) } \\
\text { (g) }\end{array}$ & $\begin{array}{l}\text { Container } \\
\text { Calibration } \\
\text { Weight } \\
\text { (Avg) (g) }\end{array}$ & $\begin{array}{l}\text { Dry } \\
\text { Sample } \\
\text { Weight } \\
\text { (N1,N2,N3) } \\
\text { (g) }\end{array}$ & $\begin{array}{l}\text { Dry } \\
\text { Sample } \\
\text { Weight } \\
\text { (Avg) (g) }\end{array}$ & $\begin{array}{l}\text { Sample } \\
\text { Weight in } \\
\text { Container } \\
\text { Filled with } \\
\text { Water } \\
\text { (N1,N2,N3) } \\
\text { (g) }\end{array}$ & $\begin{array}{l}\text { Sample } \\
\text { Weight in } \\
\text { Container } \\
\text { Filled with } \\
\text { Water } \\
\text { (Avg) (g) }\end{array}$ & $\begin{array}{l}\text { Bag } \\
\text { Weight (g) }\end{array}$ & $\begin{array}{l}\text { Rubber } \\
\text { Sheets } \\
\text { Combined } \\
\text { Wt. (g) }\end{array}$ & $\begin{array}{l}\text { Dry } \\
\text { Sample } \\
\text { Weight (g) }\end{array}$ & $\begin{array}{l}\text { Weight of } \\
\text { Sealed } \\
\text { Sample } \\
\text { Opened in } \\
\text { Water (g) }\end{array}$ & $\begin{array}{l}\text { Percent } \\
\text { Absorption }\end{array}$ & $\begin{array}{l}\text { Apparent } \\
\text { Density }\end{array}$ & $\begin{array}{l}\text { Bulk } \\
\text { Specific } \\
\text { Gravity, } \\
\text { (SSD) }\end{array}$ & $\begin{array}{l}\text { Bulk } \\
\text { Specific } \\
\text { Gravity, } \\
\text { (BSG) }\end{array}$ \\
\hline 1 & Large & 5657.9 & 5657.9 & 999.9 & 999.9 & 6280.1 & 6280.1 & 72.9 & 208.2 & 2000 & 1295.3 & 0.31 & 2.669 & 2.655 & 2.647 \\
\hline 2 & Large & 5657.9 & 5657.9 & 1000.1 & 1000.1 & 6280.5 & 6280.5 & 72.8 & 208.2 & 2000.2 & 1295.4 & 0.28 & 2.669 & 2.657 & 2.649 \\
\hline 3 & Large & 5657.9 & 5657.9 & 1000.3 & 1000.3 & 6280.6 & 6280.6 & 72.8 & 208.2 & 2000.1 & 1295.2 & 0.27 & 2.668 & 2.656 & 2.649 \\
\hline 4 & Large & 5657.9 & 5657.9 & 1000 & 1000 & 6280.2 & 6280.2 & 72.7 & 208.2 & 1999.9 & 1295 & 0.29 & 2.668 & 2.655 & 2.648 \\
\hline 5 & Large & 5657.9 & 5657.9 & 1000.4 & 1000.4 & 6280.8 & 6280.8 & 72.9 & 208.2 & 2000.4 & 1295.5 & 0.26 & 2.669 & 2.657 & 2.650 \\
\hline
\end{tabular}




\section{CoreLok Method (\# 9)}

\begin{tabular}{|c|c|c|c|c|c|c|c|c|c|c|c|c|c|c|c|}
\hline InstroTek Ag & gSpec & $3 / 7 / 2012$ & & & Sample A & & & & & Sample B & & Results & & & \\
\hline Sample ID & $\begin{array}{l}\text { Container } \\
\text { Size }\end{array}$ & $\begin{array}{l}\text { Container } \\
\text { Calibration } \\
\text { Weight } \\
\text { (N1,N2,N3) } \\
\text { (g) }\end{array}$ & $\begin{array}{l}\text { Container } \\
\text { Calibration } \\
\text { Weight } \\
\text { (Avg) (g) }\end{array}$ & $\begin{array}{l}\text { Dry } \\
\text { Sample } \\
\text { Weight } \\
\text { (N1,N2,N3) } \\
\text { (g) }\end{array}$ & $\begin{array}{l}\text { Dry } \\
\text { Sample } \\
\text { Weight } \\
\text { (Avg) (g) }\end{array}$ & $\begin{array}{l}\text { Sample } \\
\text { Weight in } \\
\text { Container } \\
\text { Filled with } \\
\text { Water } \\
\text { (N1,N2,N3) } \\
\text { (g) }\end{array}$ & $\begin{array}{l}\text { Sample } \\
\text { Weight in } \\
\text { Container } \\
\text { Filled with } \\
\text { Water } \\
\text { (Avg) (g) }\end{array}$ & $\begin{array}{l}\text { Bag } \\
\text { Weight (g) }\end{array}$ & $\begin{array}{l}\text { Rubber } \\
\text { Sheets } \\
\text { Combined } \\
\text { Wt. (g) }\end{array}$ & $\begin{array}{l}\text { Dry } \\
\text { Sample } \\
\text { Weight (g) }\end{array}$ & $\begin{array}{l}\text { Weight of } \\
\text { Sealed } \\
\text { Sample } \\
\text { Opened in } \\
\text { Water (g) }\end{array}$ & $\begin{array}{l}\text { Percent } \\
\text { Absorption }\end{array}$ & $\begin{array}{l}\text { Apparent } \\
\text { Density }\end{array}$ & $\begin{array}{l}\text { Bulk } \\
\text { Specific } \\
\text { Gravity, } \\
\text { (SSD) }\end{array}$ & $\begin{array}{l}\text { Bulk } \\
\text { Specific } \\
\text { Gravity, } \\
\text { (BSG) }\end{array}$ \\
\hline 1 & Large & 5657.7 & 5657.7 & 1000.3 & 1000.3 & 6280.9 & 6280.9 & 72.6 & 208.2 & 2000.3 & 1294.8 & 0.29 & 2.666 & 2.653 & 2.646 \\
\hline 2 & Large & 5657.7 & 5657.7 & 1000.2 & 1000.2 & 6280.8 & 6280.8 & 72.7 & 208.2 & 2000.1 & 1294.7 & 0.20 & 2.667 & 2.658 & 2.652 \\
\hline 3 & Large & 5657.7 & 5657.7 & 999.9 & 999.9 & 6280.6 & 6280.6 & 72.8 & 208.2 & 2000.4 & 1294.7 & 0.29 & 2.666 & 2.653 & 2.645 \\
\hline 4 & Large & 5657.7 & 5657.7 & 1000.1 & 1000.1 & 6280.8 & 6280.8 & 72.7 & 208.2 & 2000.2 & 1294.8 & 0.30 & 2.667 & 2.654 & 2.646 \\
\hline 5 & Large & 5657.7 & 5657.7 & 1000.2 & 1000.2 & 6280.8 & 6280.8 & 72.7 & 208.2 & 2000.1 & 1294.4 & 0.29 & 2.665 & 2.653 & 2.645 \\
\hline
\end{tabular}

\section{CoreLok Method (\# 67)}

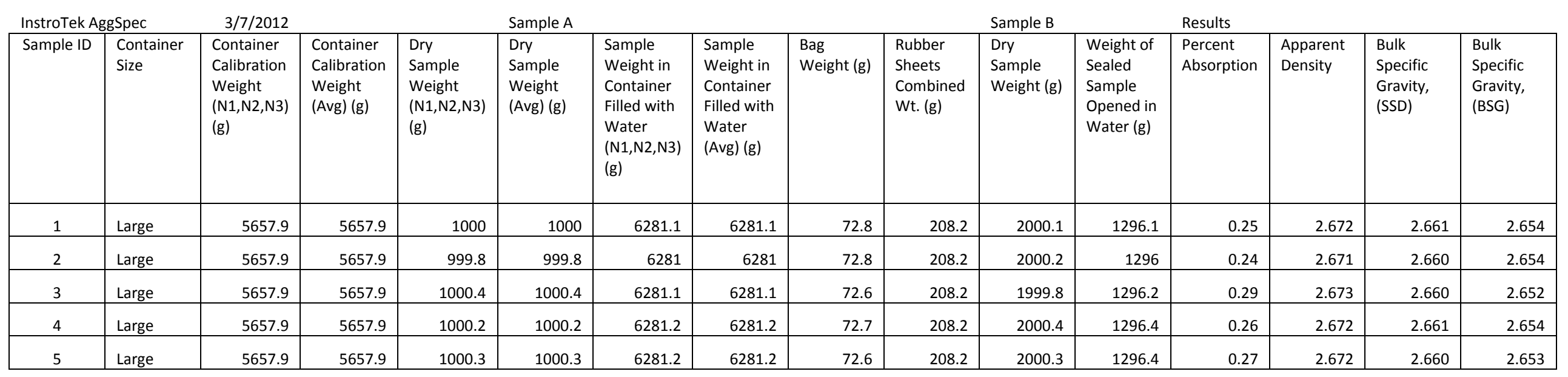




\section{APPENDIX 2 Data Summary}

Fine aggregate specific gravity and absorption results for limestone

\begin{tabular}{|c|c|c|c|c|c|}
\hline Aggregate & Test Method & Sample & $\mathrm{G}_{\mathrm{sb}}$ & $\mathrm{G}_{\mathrm{sa}}$ & \% Absorption \\
\hline Limestone & $\mathrm{T} 84$ & 1 & 2.595 & 2.710 & 1.624 \\
\hline Limestone & $\mathrm{T} 84$ & 2 & 2.599 & 2.708 & 1.541 \\
\hline Limestone & $\mathrm{T} 84$ & 3 & 2.604 & 2.711 & 1.503 \\
\hline Limestone & $\mathrm{T} 84$ & 4 & 2.594 & 2.709 & 1.645 \\
\hline Limestone & T 84 & 5 & 2.595 & 2.708 & 1.601 \\
\hline Limestone & PCT & 1 & 2.636 & 2.705 & 0.963 \\
\hline Limestone & PCT & 2 & 2.639 & 2.710 & 0.993 \\
\hline Limestone & PCT & 3 & 2.637 & 2.713 & 1.056 \\
\hline Limestone & PCT & 4 & 2.638 & 2.707 & 0.969 \\
\hline Limestone & PCT & 5 & 2.636 & 2.705 & 0.970 \\
\hline Limestone & PST & 1 & 2.624 & 2.709 & 1.191 \\
\hline Limestone & PST & 2 & 2.621 & 2.710 & 1.249 \\
\hline Limestone & PST & 3 & 2.631 & 2.717 & 1.198 \\
\hline Limestone & PST & 4 & 2.625 & 2.708 & 1.173 \\
\hline Limestone & PST & 5 & 2.626 & 2.708 & 1.154 \\
\hline Limestone & HPM & 1 & 2.634 & 2.708 & 1.032 \\
\hline Limestone & HPM & 2 & 2.638 & 2.709 & 0.993 \\
\hline Limestone & HPM & 3 & 2.630 & 2.708 & 1.092 \\
\hline Limestone & HPM & 4 & 2.625 & 2.711 & 1.211 \\
\hline Limestone & HPM & 5 & 2.622 & 2.705 & 1.172 \\
\hline T $84=$ AASHT & 84 & & & \\
\hline
\end{tabular}

T 84 = AASHTO T 84

$\mathrm{PCT}=$ Provisional Cone Test

PST $=$ Provisional Surface Test

HPM $=$ Hard Paper Method 
Fine aggregate specific gravity and absorption results for limestone

\begin{tabular}{|c|c|c|c|c|c|}
\hline Aggregate & Test Method & Sample & $\mathrm{G}_{\mathrm{sb}}$ & $\mathrm{G}_{\mathrm{sa}}$ & \% Absorption \\
\hline Limestone & $\mathrm{ADM}$ & 1 & 2.614 & 2.709 & 1.338 \\
\hline Limestone & $\mathrm{ADM}$ & 2 & 2.620 & 2.703 & 1.161 \\
\hline Limestone & $\mathrm{ADM}$ & 3 & 2.617 & 2.710 & 1.314 \\
\hline Limestone & $\mathrm{ADM}$ & 4 & 2.618 & 2.711 & 1.311 \\
\hline Limestone & $\mathrm{ADM}$ & 5 & 2.619 & 2.707 & 1.235 \\
\hline Limestone & $\mathrm{WM}$ & 1 & 2.674 & 2.710 & 0.503 \\
\hline Limestone & $\mathrm{WM}$ & 2 & 2.664 & 2.706 & 0.583 \\
\hline Limestone & $\mathrm{WM}$ & 3 & 2.662 & 2.708 & 0.643 \\
\hline Limestone & $\mathrm{WM}$ & 4 & 2.659 & 2.708 & 0.683 \\
\hline Limestone & $\mathrm{WM}$ & 5 & 2.654 & 2.703 & 0.681 \\
\hline Limestone & $\mathrm{CL}$ & 1 & 2.647 & 2.705 & 0.815 \\
\hline Limestone & $\mathrm{CL}$ & 2 & 2.646 & 2.703 & 0.800 \\
\hline Limestone & $\mathrm{CL}$ & 3 & 2.647 & 2.702 & 0.770 \\
\hline Limestone & $\mathrm{CL}$ & 4 & 2.640 & 2.702 & 0.879 \\
\hline Limestone & $\mathrm{CL}$ & 5 & 2.639 & 2.705 & 0.921 \\
\hline Limestone & $\mathrm{IM}$ & 1 & 2.627 & 2.703 & 1.067 \\
\hline Limestone & $\mathrm{IM}$ & 2 & 2.629 & 2.702 & 1.022 \\
\hline Limestone & $\mathrm{IM}$ & 3 & 2.634 & 2.707 & 1.014 \\
\hline Limestone & $\mathrm{IM}$ & 4 & 2.633 & 2.706 & 1.029 \\
\hline Limestone & $\mathrm{IM}$ & 5 & 2.635 & 2.709 & 1.038 \\
\hline ADM & & & & & \\
\hline
\end{tabular}

ADM $=$ Arizona DOT Method

$\mathrm{WM}=$ Wisconsin Method

$\mathrm{CL}=$ CoreLok Method

$\mathrm{IM}=$ Iowa Method 


\begin{tabular}{|c|c|c|c|c|c|}
\hline Aggregate & Test Method & Sample & $\mathrm{G}_{\mathrm{sb}}$ & $\mathrm{G}_{\mathrm{sa}}$ & \% Absorption \\
\hline Limestone & $\mathrm{TM}$ & 1 & 2.638 & 2.708 & 1.095 \\
\hline Limestone & $\mathrm{TM}$ & 2 & 2.640 & 2.712 & 1.133 \\
\hline Limestone & $\mathrm{TM}$ & 3 & 2.641 & 2.714 & 1.139 \\
\hline Limestone & $\mathrm{TM}$ & 4 & 2.646 & 2.705 & 0.925 \\
\hline Limestone & $\mathrm{TM}$ & 5 & 2.645 & 2.708 & 0.974 \\
\hline Limestone & $\mathrm{CT}$ & 1 & 2.631 & 2.709 & 1.100 \\
\hline Limestone & $\mathrm{CT}$ & 2 & 2.633 & 2.713 & 1.120 \\
\hline Limestone & $\mathrm{CT}$ & 3 & 2.630 & 2.711 & 1.137 \\
\hline Limestone & $\mathrm{CT}$ & 4 & 2.638 & 2.714 & 1.062 \\
\hline Limestone & $\mathrm{CT}$ & 5 & 2.635 & 2.712 & 1.071 \\
\hline
\end{tabular}

$\mathrm{TM}=$ Texas DOT Method

$\mathrm{CT}=$ California Test 225 
Fine aggregate specific gravity and absorption results for slag

\begin{tabular}{|c|c|c|c|c|c|}
\hline Aggregate & Test Method & Sample & $\mathrm{G}_{\mathrm{sb}}$ & $\mathrm{G}_{\mathrm{sa}}$ & $\%$ Absorption \\
\hline Slag & T 84 & 1 & 2.589 & 2.740 & 2.122 \\
\hline Slag & T 84 & 2 & 2.576 & 2.735 & 2.267 \\
\hline Slag & T 84 & 3 & 2.581 & 2.745 & 2.316 \\
\hline Slag & Т 84 & 4 & 2.580 & 2.736 & 2.212 \\
\hline Slag & T 84 & 5 & 2.583 & 2.748 & 2.328 \\
\hline Slag & PCT & 1 & 2.578 & 2.741 & 2.315 \\
\hline Slag & PCT & 2 & 2.584 & 2.736 & 2.148 \\
\hline Slag & PCT & 3 & 2.588 & 2.743 & 2.185 \\
\hline Slag & PCT & 4 & 2.589 & 2.732 & 2.032 \\
\hline Slag & PCT & 5 & 2.590 & 2.746 & 2.187 \\
\hline Slag & PST & 1 & 2.577 & 2.743 & 2.355 \\
\hline Slag & PST & 2 & 2.586 & 2.745 & 2.249 \\
\hline Slag & PST & 3 & 2.573 & 2.742 & 2.403 \\
\hline Slag & PST & 4 & 2.578 & 2.738 & 2.276 \\
\hline Slag & PST & 5 & 2.581 & 2.742 & 2.264 \\
\hline Slag & HPM & 1 & 2.585 & 2.740 & 2.197 \\
\hline Slag & HPM & 2 & 2.584 & 2.745 & 2.263 \\
\hline Slag & HPM & 3 & 2.575 & 2.737 & 2.295 \\
\hline Slag & HPM & 4 & 2.580 & 2.740 & 2.267 \\
\hline Slag & HPM & 5 & 2.587 & 2.738 & 2.131 \\
\hline
\end{tabular}

T 84 = AASHTO T 84

$\mathrm{PCT}=$ Provisional Cone Test

PST $=$ Provisional Surface Test

HPM $=$ Hard Paper Method 
Fine aggregate specific gravity and absorption results for slag

\begin{tabular}{|c|c|c|c|c|c|}
\hline Aggregate & Test Method & Sample & $\mathrm{G}_{\mathrm{sb}}$ & $\mathrm{G}_{\mathrm{sa}}$ & \% Absorption \\
\hline Slag & ADM & 1 & 2.590 & 2.741 & 2.122 \\
\hline Slag & ADM & 2 & 2.582 & 2.741 & 2.239 \\
\hline Slag & ADM & 3 & 2.594 & 2.736 & 2.001 \\
\hline Slag & ADM & 4 & 2.588 & 2.745 & 2.222 \\
\hline Slag & ADM & 5 & 2.591 & 2.740 & 2.101 \\
\hline Slag & WM & 1 & 2.656 & 2.743 & 1.198 \\
\hline Slag & WM & 2 & 2.649 & 2.736 & 1.193 \\
\hline Slag & WM & 3 & 2.646 & 2.741 & 1.309 \\
\hline Slag & WM & 4 & 2.641 & 2.745 & 1.443 \\
\hline Slag & WM & 5 & 2.649 & 2.745 & 1.318 \\
\hline Slag & CL & 1 & 2.593 & 2.741 & 2.079 \\
\hline Slag & CL & 2 & 2.593 & 2.741 & 2.084 \\
\hline Slag & CL & 3 & 2.587 & 2.739 & 2.148 \\
\hline Slag & CL & 4 & 2.585 & 2.742 & 2.213 \\
\hline Slag & CL & 5 & 2.596 & 2.743 & 2.066 \\
\hline Slag & IM & 1 & 2.609 & 2.739 & 1.816 \\
\hline Slag & IM & 2 & 2.614 & 2.743 & 1.797 \\
\hline Slag & IM & 3 & 2.617 & 2.739 & 1.713 \\
\hline Slag & IM & 4 & 2.618 & 2.739 & 1.677 \\
\hline Slag & IM & 5 & 2.611 & 2.744 & 1.859 \\
\hline ADM A & DOT & & & & \\
\hline
\end{tabular}

$\mathrm{ADM}=$ Arizona DOT Method

$\mathrm{WM}=$ Wisconsin Method

$\mathrm{CL}=$ CoreLok Method

$\mathrm{IM}=$ Iowa Method 
Fine aggregate specific gravity and absorption results for slag

\begin{tabular}{|c|c|c|c|c|c|}
\hline Aggregate & Test Method & Sample & $\mathrm{G}_{\mathrm{sb}}$ & $\mathrm{G}_{\mathrm{sa}}$ & \% Absorption \\
\hline Slag & TM & 1 & 2.638 & 2.739 & 1.530 \\
\hline Slag & TM & 2 & 2.641 & 2.738 & 1.480 \\
\hline Slag & TM & 3 & 2.644 & 2.740 & 1.442 \\
\hline Slag & TM & 4 & 2.640 & 2.746 & 1.611 \\
\hline Slag & TM & 5 & 2.648 & 2.739 & 1.365 \\
\hline Slag & CT & 1 & 2.605 & 2.741 & 1.908 \\
\hline Slag & CT & 2 & 2.592 & 2.738 & 2.057 \\
\hline Slag & CT & 3 & 2.591 & 2.741 & 2.115 \\
\hline Slag & CT & 4 & 2.590 & 2.743 & 2.153 \\
\hline Slag & CT & 5 & 2.599 & 2.742 & 2.002 \\
\hline
\end{tabular}

$\mathrm{TM}=$ Texas DOT Method

$\mathrm{CT}=$ California Test 225 
Coarse aggregate specific gravity and absorption results

\begin{tabular}{|c|c|c|c|c|c|c|}
\hline Aggregate & $\begin{array}{c}\text { Test } \\
\text { Method }\end{array}$ & Size & Sample & $\mathrm{G}_{\mathrm{sb}}$ & $\mathrm{G}_{\mathrm{sa}}$ & $\%$ Abs. \\
\hline Limestone & Т 85 & No. $8 \mathrm{R}$ & 1 & 2.586 & 2.667 & 1.186 \\
\hline Limestone & T 85 & No. $8 \mathrm{R}$ & 2 & 2.583 & 2.671 & 1.274 \\
\hline Limestone & T 85 & No. $8 \mathrm{R}$ & 3 & 2.587 & 2.668 & 1.176 \\
\hline Limestone & T 85 & No. $8 \mathrm{R}$ & 4 & 2.587 & 2.671 & 1.225 \\
\hline Limestone & T 85 & No. $8 \mathrm{R}$ & 5 & 2.586 & 2.667 & 1.173 \\
\hline Limestone & $\mathrm{CL}$ & No. $8 \mathrm{R}$ & 1 & 2.646 & 2.670 & 0.347 \\
\hline Limestone & $\mathrm{CL}$ & No. $8 \mathrm{R}$ & 2 & 2.648 & 2.669 & 0.305 \\
\hline Limestone & $\mathrm{CL}$ & No. $8 \mathrm{R}$ & 3 & 2.645 & 2.671 & 0.374 \\
\hline Limestone & $\mathrm{CL}$ & No. $8 \mathrm{R}$ & 4 & 2.647 & 2.669 & 0.323 \\
\hline Limestone & CL & No. $8 \mathrm{R}$ & 5 & 2.646 & 2.671 & 0.354 \\
\hline Limestone & T 85 & No. $8 \mathrm{~S}$ & 1 & 2.580 & 2.669 & 1.299 \\
\hline Limestone & T 85 & No. $8 \mathrm{~S}$ & 2 & 2.577 & 2.671 & 1.365 \\
\hline Limestone & T 85 & No. $8 \mathrm{~S}$ & 3 & 2.580 & 2.669 & 1.280 \\
\hline Limestone & T 85 & No. $8 \mathrm{~S}$ & 4 & 2.583 & 2.666 & 1.199 \\
\hline Limestone & T 85 & No. $8 \mathrm{~S}$ & 5 & 2.579 & 2.670 & 1.323 \\
\hline Limestone & $\mathrm{CL}$ & No. $8 \mathrm{~S}$ & 1 & 2.647 & 2.669 & 0.306 \\
\hline Limestone & $\mathrm{CL}$ & No. $8 \mathrm{~S}$ & 2 & 2.649 & 2.669 & 0.277 \\
\hline Limestone & $\mathrm{CL}$ & No. $8 \mathrm{~S}$ & 3 & 2.649 & 2.668 & 0.273 \\
\hline Limestone & $\mathrm{CL}$ & No. $8 \mathrm{~S}$ & 4 & 2.648 & 2.668 & 0.290 \\
\hline Limestone & $\mathrm{CL}$ & No. $8 \mathrm{~S}$ & 5 & 2.650 & 2.669 & 0.265 \\
\hline
\end{tabular}

T $85=$ AASHTO T 85

$\mathrm{CL}=$ CoreLok Method

No.8 $\mathrm{R}=$ Number 8 Regular

No. $8 \mathrm{~S}=$ Number 8 Skid 
Coarse aggregate specific gravity and absorption results

\begin{tabular}{|c|c|c|c|c|c|c|}
\hline Aggregate & $\begin{array}{c}\text { Test } \\
\text { Method }\end{array}$ & Size & Sample & $\mathrm{G}_{\mathrm{sb}}$ & $\mathrm{G}_{\mathrm{sa}}$ & \% Abs. \\
\hline Limestone & T 85 & No. 9 & 1 & 2.591 & 2.651 & 0.874 \\
\hline Limestone & T 85 & No. 9 & 2 & 2.589 & 2.652 & 0.913 \\
\hline Limestone & T 85 & No. 9 & 3 & 2.587 & 2.655 & 0.979 \\
\hline Limestone & T 85 & No. 9 & 4 & 2.592 & 2.651 & 0.870 \\
\hline Limestone & T 85 & No. 9 & 5 & 2.588 & 2.654 & 0.966 \\
\hline Limestone & CL & No. 9 & 1 & 2.646 & 2.666 & 0.295 \\
\hline Limestone & CL & No. 9 & 2 & 2.652 & 2.667 & 0.201 \\
\hline Limestone & CL & No. 9 & 3 & 2.645 & 2.666 & 0.293 \\
\hline Limestone & CL & No. 9 & 4 & 2.646 & 2.667 & 0.297 \\
\hline Limestone & CL & No. 9 & 5 & 2.645 & 2.665 & 0.286 \\
\hline Limestone & T 85 & No. 67 & 1 & 2.564 & 2.686 & 1.784 \\
\hline Limestone & T 85 & No. 67 & 2 & 2.570 & 2.687 & 1.703 \\
\hline Limestone & T 85 & No. 67 & 3 & 2.568 & 2.681 & 1.641 \\
\hline Limestone & T 85 & No. 67 & 4 & 2.574 & 2.685 & 1.612 \\
\hline Limestone & T 85 & No. 67 & 5 & 2.567 & 2.686 & 1.737 \\
\hline Limestone & CL & No. 67 & 1 & 2.654 & 2.672 & 0.249 \\
\hline Limestone & CL & No. 67 & 2 & 2.654 & 2.671 & 0.238 \\
\hline Limestone & CL & No. 67 & 3 & 2.652 & 2.673 & 0.287 \\
\hline Limestone & CL & No. 67 & 4 & 2.654 & 2.672 & 0.257 \\
\hline Limestone & CL & No. 67 & 5 & 2.653 & 2.672 & 0.265 \\
\hline & T $85=$ AAS & T 85 & & & & \\
\hline
\end{tabular}

T 85 = AASHTO T 85

$\mathrm{CL}=$ CoreLok Method 


\section{APPENDIX 3 Student t results}

\section{Limestone fine aggregates}

Provisional Cone test vs Standard AASHTO T84

$\mathrm{G}_{\mathrm{sb}}$

t-Test: Two-Sample Assuming Equal Variances

\begin{tabular}{lrr}
\hline & Variable 1 & Variable 2 \\
\hline Mean & 2.63729633 & 2.5976864 \\
Variance & $1.4257 \mathrm{E}-06$ & $1.85 \mathrm{E}-05$ \\
Observations & 5 & 5 \\
Pooled Variance & $9.9608 \mathrm{E}-06$ & \\
Hypothesized Mean & & \\
Difference & 0 & \\
df & 8 & \\
t Stat & 19.8439104 & \\
$\mathrm{P}(\mathrm{T}<=\mathrm{t})$ one-tail & $2.1663 \mathrm{E}-08$ & \\
$\mathrm{t}$ Critical one-tail & 1.85954804 & \\
$\mathrm{P}(\mathrm{T}<=\mathrm{t})$ two-tail & $4.3326 \mathrm{E}-08$ & \\
$\mathrm{t}$ Critical two-tail & 2.30600414 & \\
\hline Decision & reject Ho &
\end{tabular}

Provisional Surface test vs Standard AASHTO T84

t-Test: Two-Sample Assuming Equal Variances

\begin{tabular}{lrr}
\hline & Variable 1 & Variable 2 \\
\hline Mean & 2.62555719 & 2.5976864 \\
Variance & $1.4557 \mathrm{E}-05$ & $1.85 \mathrm{E}-05$ \\
Observations & 5 & 5 \\
Pooled Variance & $1.6526 \mathrm{E}-05$ &
\end{tabular}

\% Absorption

t-Test: Two-Sample Assuming Equal Variances

\begin{tabular}{lrr}
\hline & Variable 1 & \multicolumn{1}{c}{ Variable 2 } \\
\hline Mean & 0.989966962 & 1.5828633 \\
Variance & 0.001478676 & 0.00352858 \\
Observations & 5 & 5 \\
Pooled Variance & 0.002503628 & \\
Hypothesized Mean & & \\
Difference & 0 & \\
df & 8 &
\end{tabular}

$\mathrm{P}(\mathrm{T}<=\mathrm{t})$ one-tail

$\mathrm{t}$ Critical one-tail $\quad 1.859548038$

t Critical two-tail

2.306004135

Decision

reject $\mathrm{Ho}$
$\mathrm{P}(\mathrm{T}<=\mathrm{t})$ two-tail $\quad 6.80249 \mathrm{E}-08$

$\mathrm{G}_{\mathrm{sa}}$

t-Test: Two-Sample Assuming Equal Variances

\begin{tabular}{lrr}
\hline & Variable 1 & Variable 2 \\
\hline Mean & 2.7080004 & 2.709072 \\
Variance & $1.056 \mathrm{E}-05$ & $1.261 \mathrm{E}-06$ \\
Observations & 5 & 5
\end{tabular}

Pooled Variance 5.91E-06

Hypothesized Mean

Difference

df

$\mathrm{P}(\mathrm{T}<=\mathrm{t})$ one-tail $\quad 0.2527846$

t Critical one-tail $\quad 1.859548$

$\mathrm{P}(\mathrm{T}<=\mathrm{t})$ two-tail $\quad 0.5055692$

$\mathrm{t}$ Critical two-tail $\quad 2.3060041$

Decision cannot reject Ho

$\mathrm{G}_{\mathrm{sa}}$

t-Test: Two-Sample Assuming Equal Variances

\begin{tabular}{lrr}
\hline & Variable 1 & \multicolumn{1}{c}{ Variable 2 } \\
\hline Mean & 1.192836724 & 1.5828633 \\
Variance & 0.001274891 & 0.00352858 \\
Observations & 5 & 5 \\
Pooled Variance & 0.002401736 &
\end{tabular}

t-Test: Two-Sample Assuming Equal Variances

\begin{tabular}{lrr} 
& Variable 1 & Variable 2 \\
\hline Mean & 2.7104439 & 2.709072 \\
Variance & $1.398 \mathrm{E}-05$ & $1.261 \mathrm{E}-06$ \\
Observations & 5 & 5 \\
Pooled Variance & $7.619 \mathrm{E}-06$ &
\end{tabular}




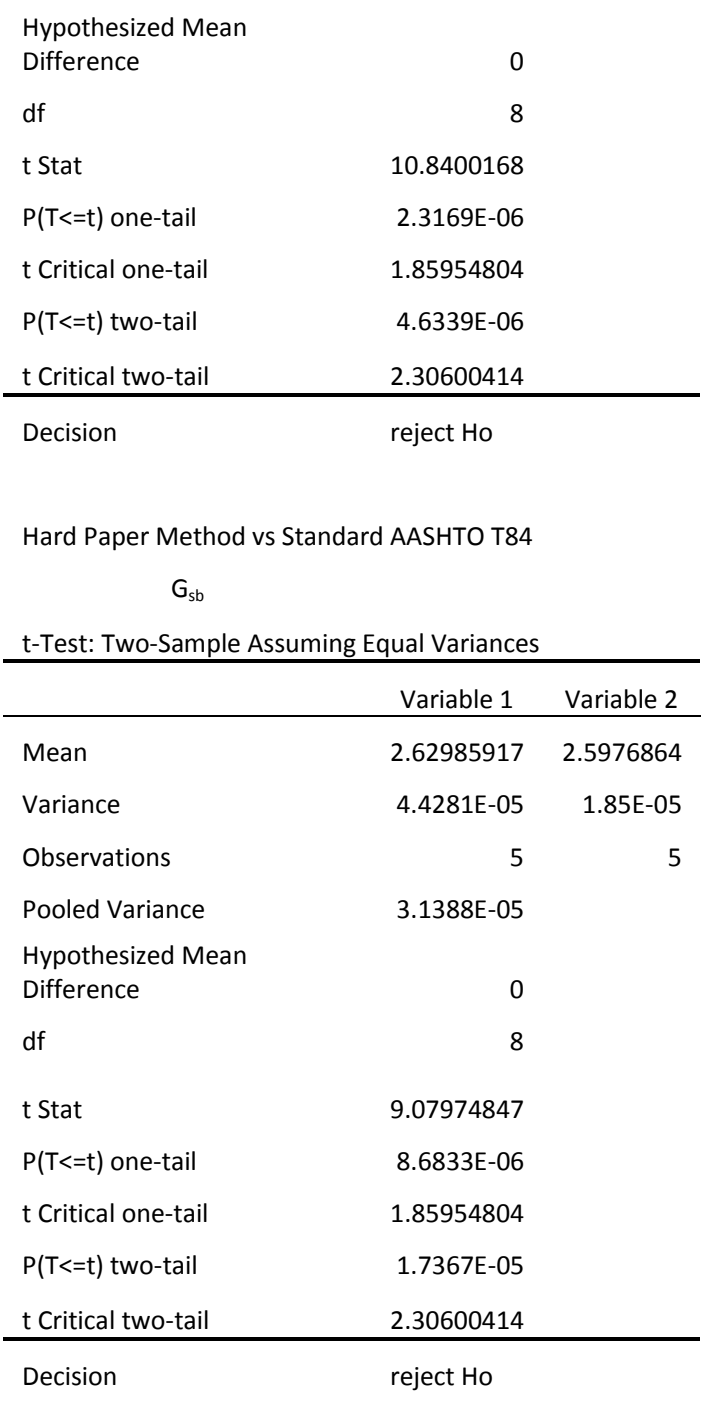

\begin{tabular}{lr} 
Hypothesized Mean & \\
Difference & 0 \\
df & 8 \\
t Stat & -12.583504 \\
$\mathrm{P}(\mathrm{T}<=\mathrm{t})$ one-tail & $7.45906 \mathrm{E}-07$ \\
$\mathrm{t}$ Critical one-tail & 1.859548038 \\
$\mathrm{P}(\mathrm{T}<=\mathrm{t})$ two-tail & $1.49181 \mathrm{E}-06$ \\
$\mathrm{t}$ Critical two-tail & 2.306004135 \\
\hline Decision & reject Ho
\end{tabular}

Hypothesized Mean

Difference

0

df

$\mathrm{P}(\mathrm{T}<=\mathrm{t})$ one-tail $\quad 0.2272835$

$\mathrm{t}$ Critical one-tail $\quad 1.859548$

$\mathrm{P}(\mathrm{T}<=\mathrm{t})$ two-tail $\quad 0.454567$

$\mathrm{t}$ Critical two-tail $\quad 2.3060041$

Decision cannot reject Ho

\% Absorption

$\mathrm{t}$-Test: Two-Sample Assuming Equal Variances $\quad \mathrm{t}$-Test: Two-Sample Assuming Equal Variances

\begin{tabular}{lcc} 
& Variable 1 & Variable 2 \\
\hline Mean & 1.099723816 & 1.5828633
\end{tabular}

Mean $\quad 1.099723816 \quad 1.5828633$

Variance $\quad 0.008399526 \quad 0.00352858$

Observations

Pooled Variance $\quad 0.005964054$

Hypothesized Mean

Difference 0

df

\begin{tabular}{lrr} 
& Variable 1 & Variable 2 \\
\hline Mean & 2.7081703 & 2.709072 \\
Variance & $5.164 \mathrm{E}-06$ & $1.261 \mathrm{E}-06$ \\
Observations & 5 & 5 \\
Pooled Variance & &
\end{tabular}

Pooled Variance $\quad 3.212 \mathrm{E}-06$

Hypothesized Mean

Difference 0

df

\begin{tabular}{lr}
$\mathrm{t}$ Stat & -9.89171898 \\
$\mathrm{P}(\mathrm{T}<=\mathrm{t})$ one-tail & $4.6032 \mathrm{E}-06$ \\
$\mathrm{t}$ Critical one-tail & 1.859548038 \\
$\mathrm{P}(\mathrm{T}<=\mathrm{t})$ two-tail & $9.2064 \mathrm{E}-06$ \\
$\mathrm{t}$ Critical two-tail & 2.306004135 \\
\hline Decision & reject Ho
\end{tabular}

t Stat

0.7954625

$\mathrm{P}(\mathrm{T}<=\mathrm{t})$ one-tail $\quad 0.22465$

$\mathrm{t}$ Critical one-tail $\quad 1.859548$

$\mathrm{P}(\mathrm{T}<=\mathrm{t})$ two-tail $\quad 0.4493001$

$\mathrm{t}$ Critical two-tail $\quad 2.3060041$

Decision cannot reject Ho

$\mathrm{G}_{\text {sa }}$

t-Test: Two-Sample Assuming Equal Variances

t-Test: Two-Sample Assuming Equal Variances 


\begin{tabular}{|c|c|c|}
\hline & Variable 1 & Variable 2 \\
\hline Mean & 2.61774436 & 2.5976864 \\
\hline Variance & $5.8268 \mathrm{E}-06$ & $1.85 \mathrm{E}-05$ \\
\hline Observations & 5 & 5 \\
\hline Pooled Variance & $1.2161 \mathrm{E}-05$ & \\
\hline $\begin{array}{l}\text { Hypothesized Mea } \\
\text { Difference }\end{array}$ & 0 & \\
\hline df & 8 & \\
\hline t Stat & 9.09422685 & \\
\hline $\mathrm{P}(\mathrm{T}<=\mathrm{t})$ one-tail & $8.5821 E-06$ & \\
\hline t Critical one-tail & 1.85954804 & \\
\hline $\mathrm{P}(\mathrm{T}<=\mathrm{t})$ two-tail & $1.7164 \mathrm{E}-05$ & \\
\hline t Critical two-tail & 2.30600414 & \\
\hline Decision & reject Ho & \\
\hline \multirow{2}{*}{\multicolumn{3}{|c|}{$\begin{array}{l}\text { Wisconsin Method vs Standard AASHTO T84 } \\
\qquad \mathrm{G}_{\mathrm{sb}} \\
\text { t-Test: Two-Sample Assuming Equal Variances }\end{array}$}} \\
\hline & & \\
\hline & Variable 1 & Variable 2 \\
\hline Mean & 2.66234141 & 2.5976864 \\
\hline Variance & 5.3837E-05 & $1.85 \mathrm{E}-05$ \\
\hline Observations & 5 & 5 \\
\hline Pooled Variance & 3.6166E-05 & \\
\hline $\begin{array}{l}\text { Hypothesized Mea } \\
\text { Difference }\end{array}$ & 0 & \\
\hline df & 8 & \\
\hline t Stat & 16.9988323 & \\
\hline $\mathrm{P}(\mathrm{T}<=\mathrm{t})$ one-tail & $7.28 \mathrm{E}-08$ & \\
\hline t Critical one-tail & 1.85954804 & \\
\hline $\mathrm{P}(\mathrm{T}<=\mathrm{t})$ two-tail & $1.456 \mathrm{E}-07$ & \\
\hline t Critical two-tail & 2.30600414 & \\
\hline
\end{tabular}

\begin{tabular}{lrr} 
& Variable 1 & Variable 2 \\
\hline Mean & 1.271570538 & 1.5828633 \\
Variance & 0.00533844 & 0.00352858 \\
Observations & 5 & 5 \\
Pooled Variance & 0.00443351 & \\
Hypothesized Mean & 0 \\
Difference & 8 \\
df & -7.39205463 \\
t Stat & $3.838855-05$ \\
P(T<=t) one-tail & 1.859548038 \\
t Critical one-tail & $7.6777 \mathrm{E}-05$ & \\
$\mathrm{P}(\mathrm{T}<=\mathrm{t})$ two-tail & 2.306004135 & \\
$\mathrm{t}$ Critical two-tail & reject Ho
\end{tabular}

\begin{tabular}{lrr} 
& & \\
\hline Mean & Variable 1 & Variable 2 \\
Variance & 2.7078816 & 2.709072 \\
Observations & 5 & 5 \\
Pooled Variance & $6.382 \mathrm{E}-06$ & \\
Hypothesized Mean & & \\
Difference & 0 \\
df & 8 \\
t Stat & - \\
$\mathrm{P}(\mathrm{T}<=\mathrm{t})$ one-tail & 0.7450203 & \\
$\mathrm{t}$ Critical one-tail & 0.2387867 & \\
$\mathrm{P}(\mathrm{T}<=\mathrm{t})$ two-tail & 1.859548 \\
$\mathrm{t}$ Critical two-tail & 0.4775734 & \\
\hline Decision & 2.3060041 &
\end{tabular}

$\%$ Absorption

$\mathrm{G}_{\mathrm{sa}}$

$\mathrm{t}$-Test: Two-Sample Assuming Equal Variances $\quad$ t-Test: Two-Sample Assuming Equal Variances

\begin{tabular}{|c|c|c|c|c|c|}
\hline & Variable 1 & Variable 2 & & Variable 1 & Variable 2 \\
\hline Mean & 0.618462913 & 1.5828633 & Mean & 2.7068979 & 2.709072 \\
\hline Variance & 0.005839103 & 0.00352858 & Variance & $7.623 \mathrm{E}-06$ & $1.261 \mathrm{E}-06$ \\
\hline Observations & 5 & 5 & Observations & 5 & 5 \\
\hline Pooled Variance & 0.004683842 & & Pooled Variance & $4.442 \mathrm{E}-06$ & \\
\hline Hypothesized Mean & & & Hypothesized Mean & & \\
\hline Difference & 0 & & Difference & 0 & \\
\hline df & 8 & & df & 8 & \\
\hline t Stat & -22.2805683 & & t Stat & -1.631008 & \\
\hline $\mathrm{P}(\mathrm{T}<=\mathrm{t})$ one-tail & $8.70522 \mathrm{E}-09$ & & $\mathrm{P}(\mathrm{T}<=\mathrm{t})$ one-tail & 0.0707673 & \\
\hline t Critical one-tail & 1.859548038 & & t Critical one-tail & 1.859548 & \\
\hline $\mathrm{P}(\mathrm{T}<=\mathrm{t})$ two-tail & $1.74104 \mathrm{E}-08$ & & $\mathrm{P}(\mathrm{T}<=\mathrm{t})$ two-tail & 0.1415346 & \\
\hline t Critical two-tail & 2.306004135 & & t Critical two-tail & 2.3060041 & \\
\hline
\end{tabular}


Corelok Method vs Standard AASHTO T84

t-Test: Two-Sample Assuming Equal Variances

\begin{tabular}{lrr}
\hline & Variable 1 & Variable 2 \\
\hline Mean & 2.6438 & 2.5976864 \\
Variance & $1.57 \mathrm{E}-05$ & $1.85 \mathrm{E}-05$ \\
Observations & 5 & 5 \\
Pooled Variance & $1.7098 \mathrm{E}-05$ & \\
Hypothesized Mean & 0 & \\
Difference & 8 & \\
df & & \\
$\mathrm{t}$ Stat & 17.6330301 & \\
$\mathrm{P}(\mathrm{T}<=\mathrm{t})$ one-tail & $5.4682 \mathrm{E}-08$ & \\
$\mathrm{t}$ Critical one-tail & 1.85954804 & \\
$\mathrm{P}(\mathrm{T}<=\mathrm{t})$ two-tail & $1.0936 \mathrm{E}-07$ & \\
$\mathrm{t}$ Critical two-tail & 2.30600414 & \\
\hline Decision & reject Ho
\end{tabular}

lowa Method vs Standard AASHTO T 84

$$
\mathrm{G}_{\mathrm{sb}}
$$

t-Test: Two-Sample Assuming Equal Variances

\begin{tabular}{lrr}
\hline & Variable 1 & Variable 2 \\
\hline Mean & 2.63185445 & 2.5976864 \\
Variance & $1.1718 \mathrm{E}-05$ & $1.85 \mathrm{E}-05$ \\
Observations & 5 & 5 \\
$\begin{array}{l}\text { Pooled Variance } \\
\text { Hypothesized Mean }\end{array}$ & $1.5107 \mathrm{E}-05$ & \\
Difference & 0 & \\
df & 8 &
\end{tabular}

\% Absorption

t-Test: Two-Sample Assuming Equal Variances

\begin{tabular}{lrr} 
& Variable 1 & Variable 2 \\
\hline Mean & 0.837 & 1.5828633 \\
Variance & 0.0037905 & 0.00352858 \\
Observations & 5 & 5 \\
Pooled Variance & 0.00365954 & \\
Hypothesized Mean & 0 & \\
Difference & 8 & \\
df & & \\
$t$ Stat & -19.494674 & \\
P(T<=t) one-tail & $2.49049 \mathrm{E}-08$ & \\
$\mathrm{t}$ Critical one-tail & 1.859548038 & \\
$\mathrm{P}(\mathrm{T}<=\mathrm{t})$ two-tail & $4.98098 \mathrm{E}-08$ & \\
$\mathrm{t}$ Critical two-tail & 2.306004135 & \\
\hline Decision & reject $\mathrm{Ho}$ &
\end{tabular}

\% Absorption

t-Test: Two-Sample Assuming Equal Variances

\begin{tabular}{lrr}
\hline & Variable 1 & \multicolumn{1}{c}{ Variable 2 } \\
\hline Mean & 1.033838337 & 1.5828633 \\
Variance & 0.000415527 & 0.00352858 \\
Observations & 5 & 5 \\
$\begin{array}{l}\text { Pooled Variance } \\
\text { Hypothesized Mean } \\
\text { Difference }\end{array}$ & 0.001972054 & \\
df & 0 &
\end{tabular}

$\mathrm{G}_{\text {sa }}$

t-Test: Two-Sample Assuming Equal Variances

\begin{tabular}{lrr}
\hline & Variable 1 & Variable 2 \\
\hline Mean & 2.7034 & 2.709072 \\
Variance & $2.3 \mathrm{E}-06$ & $1.261 \mathrm{E}-06$ \\
Observations & 5 & 5 \\
Pooled Variance & $1.781 \mathrm{E}-06$ & \\
Hypothesized Mean & & \\
Difference & 0 & \\
df & 8 & \\
t Stat & - & \\
$\mathrm{P}(\mathrm{T}<=\mathrm{t})$ one-tail & 6.7208637 & \\
$\mathrm{t}$ Critical one-tail & $7.473 \mathrm{E}-05$ & \\
$\mathrm{P}(\mathrm{T}<=\mathrm{t})$ two-tail & 1.859548 & \\
$\mathrm{t}$ Critical two-tail & 0.0001495 & \\
\hline Decision & 2.3060041 & \\
& reject Ho
\end{tabular}

$\mathrm{G}_{\mathrm{sa}}$

t-Test: Two-Sample Assuming Equal Variances

\begin{tabular}{lrr}
\hline & Variable 1 & Variable 2 \\
\hline Mean & 2.7054668 & 2.709072 \\
Variance & $9.217 \mathrm{E}-06$ & $1.261 \mathrm{E}-06$ \\
Observations & 5 & 5 \\
$\begin{array}{l}\text { Pooled Variance } \\
\text { Hypothesized Mean }\end{array}$ & $5.239 \mathrm{E}-06$ & \\
Difference & 0 & \\
df & 8 &
\end{tabular}




\begin{tabular}{|c|c|c|c|c|c|}
\hline t Stat & 13.8995567 & t Stat & -19.5480183 & t Stat & -2.490391 \\
\hline $\mathrm{P}(\mathrm{T}<=\mathrm{t})$ one-tail & $3.4731 \mathrm{E}-07$ & $\mathrm{P}(\mathrm{T}<=\mathrm{t})$ one-tail & $2.43762 \mathrm{E}-08$ & $\mathrm{P}(\mathrm{T}<=\mathrm{t})$ one-tail & 0.0187497 \\
\hline t Critical one-tail & 1.85954804 & t Critical one-tail & 1.859548038 & t Critical one-tail & 1.859548 \\
\hline $\mathrm{P}(\mathrm{T}<=\mathrm{t})$ two-tail & $6.9463 \mathrm{E}-07$ & $\mathrm{P}(\mathrm{T}<=\mathrm{t})$ two-tail & $4.87525 \mathrm{E}-08$ & $\mathrm{P}(\mathrm{T}<=\mathrm{t})$ two-tail & 0.0374994 \\
\hline t Critical two-tail & 2.30600414 & t Critical two-tail & 2.306004135 & t Critical two-tail & 2.3060041 \\
\hline Decision & reject Ho & Decision & reject Ho & Decision & reject Ho \\
\hline
\end{tabular}

Texas Method vs Standard AASHTO T84

$$
\mathrm{G}_{\mathrm{sb}}
$$

t-Test: Two-Sample Assuming Equal Variances

\begin{tabular}{lrr}
\hline & Variable 1 & Variable 2 \\
\hline Mean & 2.64190449 & 2.5976864 \\
Variance & $1.158 \mathrm{E}-05$ & $1.85 \mathrm{E}-05$ \\
Observations & 5 & 5 \\
Pooled Variance & $1.5038 \mathrm{E}-05$ & \\
Hypothesized Mean & 0 & \\
Difference & 8 & \\
df & 18.0290706 \\
t Stat & $4.596 \mathrm{E}-08$ & \\
$\mathrm{P}(\mathrm{T}<=\mathrm{t})$ one-tail & 1.85954804 & \\
$\mathrm{t}$ Critical one-tail & $9.192 \mathrm{E}-08$ & \\
$\mathrm{P}(\mathrm{T}<=\mathrm{t})$ two-tail & 2.30600414 & \\
$\mathrm{t}$ Critical two-tail & reject Ho
\end{tabular}

California Test 225 vs Standard AASHTO T84

$$
\mathrm{G}_{\mathrm{sb}}
$$

t-Test: Two-Sample Assuming Equal Variances

\begin{tabular}{lrr}
\hline & Variable 1 & Variable 2 \\
\hline Mean & 2.63329849 & 2.5976864 \\
Variance & $9.135 \mathrm{E}-06$ & $1.85 \mathrm{E}-05$
\end{tabular}

\% Absorption

t-Test: Two-Sample Assuming Equal Variances

\begin{tabular}{lrr}
\hline & Variable 1 & \multicolumn{1}{c}{ Variable 2 } \\
\hline Mean & 1.053127879 & 1.5828633 \\
Variance & 0.009507336 & 0.00352858 \\
Observations & 5 & 5 \\
Pooled Variance & 0.006517958 & \\
Hypothesized Mean & & \\
Difference & 0 & \\
df & 8 &
\end{tabular}

$\mathrm{P}(\mathrm{T}<=\mathrm{t})$ one-tail

$\mathrm{t}$ Critical one-tail $\quad 1.859548038$

$\mathrm{P}(\mathrm{T}<=\mathrm{t})$ two-tail $\quad 6.44576 \mathrm{E}-06$

$\mathrm{t}$ Critical two-tail $\quad 2.306004135$

Decision reject Ho

\% Absorption

t-Test: Two-Sample Assuming Equal Variances

\begin{tabular}{lcc} 
& Variable 1 & Variable 2 \\
\hline Mean & 1.097871659 & 1.5828633 \\
Variance & 0.000986974 & 0.00352858
\end{tabular}

\section{$\mathrm{G}_{\mathrm{sa}}$}

t-Test: Two-Sample Assuming Equal Variances

\begin{tabular}{lrr}
\hline & Variable 1 & Variable 2 \\
\hline Mean & 2.7094727 & 2.709072 \\
Variance & $1.459 \mathrm{E}-05$ & $1.261 \mathrm{E}-06$ \\
Observations & 5 & 5 \\
Pooled Variance & $7.924 \mathrm{E}-06$ & \\
Hypothesized Mean & 0 \\
Difference & 8 \\
df & 0.2250725 \\
t Stat & 0.4137828 \\
P(T<=t) one-tail & 1.859548 \\
$\mathrm{t}$ Critical one-tail & 0.8275656 \\
$\mathrm{P}(\mathrm{T}<=\mathrm{t})$ two-tail & 2.3060041 & \\
$\mathrm{t}$ Critical two-tail & \multicolumn{2}{|}{ cannot reject Ho }
\end{tabular}

$\mathrm{G}_{\mathrm{sa}}$

t-Test: Two-Sample Assuming Equal Variances

\begin{tabular}{lrr}
\hline & Variable 1 & Variable 2 \\
\hline Mean & 2.711692 & 2.709072 \\
Variance & $2.569 \mathrm{E}-06$ & $1.261 \mathrm{E}-06$
\end{tabular}




\begin{tabular}{|c|c|c|c|c|c|c|c|c|}
\hline Observations & 5 & 5 & Observations & 5 & 5 & Observations & 5 & 5 \\
\hline $\begin{array}{l}\text { Pooled Variance } \\
\text { Hvpothesized Mean }\end{array}$ & $1.3815 \mathrm{E}-05$ & & $\begin{array}{l}\text { Pooled Variance } \\
\text { Hvpothesized Mean }\end{array}$ & 0.002257777 & & $\begin{array}{l}\text { Pooled Variance } \\
\text { Hypothesized Mean }\end{array}$ & $1.915 \mathrm{E}-06$ & \\
\hline Difference & 0 & & Difference & 0 & & Difference & 0 & \\
\hline t Stat & 15.1490248 & & t Stat & -16.1385201 & & t Stat & 2.993395 & \\
\hline $\mathrm{P}(\mathrm{T}<=\mathrm{t})$ one-tail & $1.7845 \mathrm{E}-07$ & & $\mathrm{P}(\mathrm{T}<=\mathrm{t})$ one-tail & $1.09136 \mathrm{E}-07$ & & $\mathrm{P}(\mathrm{T}<=\mathrm{t})$ one-tail & 0.0086222 & \\
\hline t Critical one-tail & 1.85954804 & & t Critical one-tail & 1.859548038 & & t Critical one-tail & 1.859548 & \\
\hline $\mathrm{P}(\mathrm{T}<=\mathrm{t})$ two-tail & $3.569 \mathrm{E}-07$ & & $\mathrm{P}(\mathrm{T}<=\mathrm{t})$ two-tail & $2.18271 \mathrm{E}-07$ & & $\mathrm{P}(\mathrm{T}<=\mathrm{t})$ two-tail & 0.0172444 & \\
\hline t Critical two-tail & 2.30600414 & & t Critical two-tail & 2.306004135 & & t Critical two-tail & 2.3060041 & \\
\hline Decision & reject Ho & & Decision & reject Ho & & Decision & reject Ho & \\
\hline
\end{tabular}

Provisional Surface test vs Provisional Cone test$$
\mathrm{G}_{\mathrm{sb}}
$$

t-Test: Two-Sample Assuming Equal Variances

\begin{tabular}{lrr}
\hline & Variable 1 & Variable 2 \\
\hline Mean & 2.62555719 & 2.6372963 \\
Variance & $1.4557 \mathrm{E}-05$ & $1.426 \mathrm{E}-06$ \\
Observations & 5 & 5 \\
Pooled Variance & $7.9913 \mathrm{E}-06$ & \\
Hypothesized Mean & & \\
Difference & 0 & \\
df & 8 & \\
$t$ Stat & -6.5659513 & \\
$\mathrm{P}(\mathrm{T}<=\mathrm{t})$ one-tail & $8.7759 \mathrm{E}-05$ & \\
$\mathrm{t}$ Critical one-tail & 1.85954804 & \\
$\mathrm{P}(\mathrm{T}<=\mathrm{t})$ two-tail & 0.00017552 & \\
$\mathrm{t}$ Critical two-tail & 2.30600414 & \\
\hline
\end{tabular}
reject Ho

\% Absorption

t-Test: Two-Sample Assuming Equal Variances

\begin{tabular}{lrr}
\hline & Variable 1 & Variable 2 \\
\hline Mean & 1.192836724 & 0.98996696 \\
Variance & 0.001274891 & 0.00147868 \\
Observations & 5 & 5 \\
Pooled Variance & 0.001376784 & \\
Hypothesized Mean & 0 & \\
Difference & 8 & \\
df & & \\
t Stat & 8.644790524 & \\
P(T<=t) one-tail & $1.24456 \mathrm{E}-05$ & \\
$\mathrm{t}$ Critical one-tail & 1.859548038 & \\
$\mathrm{P}(\mathrm{T}<=\mathrm{t})$ two-tail & $2.48912 \mathrm{E}-05$ & \\
$\mathrm{t}$ Critical two-tail & 2.306004135 & \\
\hline
\end{tabular}

\section{$\mathrm{G}_{\mathrm{sa}}$}

t-Test: Two-Sample Assuming Equal Variances

\begin{tabular}{lrr}
\hline & Variable 1 & Variable 2 \\
\hline Mean & 2.7104439 & 2.7080004 \\
Variance & $1.398 \mathrm{E}-05$ & $1.056 \mathrm{E}-05$ \\
Observations & 5 & 5 \\
Pooled Variance & $1.227 \mathrm{E}-05$ & \\
Hypothesized Mean & & \\
Difference & 0 \\
df & 8 \\
$\mathrm{t}$ Stat & 1.1031012 \\
$\mathrm{P}(\mathrm{T}<=\mathrm{t})$ one-tail & 0.1510287 \\
$\mathrm{t}$ Critical one-tail & 1.859548 \\
$\mathrm{P}(\mathrm{T}<=\mathrm{t})$ two-tail & 0.3020573 \\
$\mathrm{t}$ Critical two-tail & 2.3060041 \\
\hline Decision & cannot reject $\mathrm{Ho}$
\end{tabular}

Hard Paper Method vs Provisional cone test 
$G_{s b}$

\begin{tabular}{lrr} 
t-Test: Two-Sample Assuming Equal Variances \\
\hline & Variable 1 & Variable 2 \\
\hline Mean & 2.62985917 & 2.6372963 \\
Variance & $4.4281 \mathrm{E}-05$ & $1.426 \mathrm{E}-06$ \\
Observations & 5 & 5 \\
Pooled Variance & $2.2853 \mathrm{E}-05$ & \\
Hypothesized Mean & & \\
Difference & 0 & \\
df & 8 & \\
t Stat & -2.4598167 & \\
$\mathrm{P}(\mathrm{T}<=\mathrm{t})$ one-tail & 0.019665 & \\
$\mathrm{t}$ Critical one-tail & 1.85954804 & \\
$\mathrm{P}(\mathrm{T}<=\mathrm{t})$ two-tail & 0.03933 & \\
$\mathrm{t}$ Critical two-tail & 2.30600414 & \\
\hline
\end{tabular}

Decision

reject Ho

Arizona DOT vs Provisional Cone test

$\mathrm{G}_{\mathrm{sb}}$

t-Test: Two-Sample Assuming Equal Variances

\begin{tabular}{lrr}
\hline & Variable 1 & Variable 2 \\
\hline Mean & 2.61774436 & 2.6372963 \\
Variance & $5.8268 \mathrm{E}-06$ & $1.426 \mathrm{E}-06$ \\
Observations & 5 & 5 \\
Pooled Variance & $3.6262 \mathrm{E}-06$ & \\
Hypothesized Mean & & \\
Difference & 0 & \\
df & 8 & \\
t Stat & & \\
P(T<=t) one-tail & -16.234258 & \\
t Critical one-tail & $1.0422 \mathrm{E}-07$ & \\
& 1.85954804 &
\end{tabular}

$\%$ Absorption

t-Test: Two-Sample Assuming Equal Variances

\begin{tabular}{lrr}
\hline & Variable 1 & Variable 2 \\
\hline Mean & 1.099723816 & 0.98996696 \\
Variance & 0.008399526 & 0.00147868 \\
Observations & 5 & 5 \\
Pooled Variance & 0.004939101 & \\
Hypothesized Mean & & \\
Difference & 0 & \\
df & 8 &
\end{tabular}

t Stat

2.469321757

$\mathrm{P}(\mathrm{T}<=\mathrm{t})$ one-tail

0.019375703

$\mathrm{t}$ Critical one-tail

1.859548038

$P(T<=t)$ two-tail

0.038751406

$\mathrm{t}$ Critical two-tail

2.306004135

Decision

reject $\mathrm{Ho}$

$\%$ Absorption

t-Test: Two-Sample Assuming Equal Variances

\begin{tabular}{lr}
\hline & \multicolumn{1}{c}{ Variable 1 } \\
\hline Mean & 1.271570538 \\
Variance & 0.00533844 \\
Observations & 5 \\
Pooled Variance & 0.003408558 \\
Hypothesized Mean & 0 \\
Difference & 8 \\
df & \\
t Stat & 7.626456799 \\
P(T<=t) one-tail & $3.07538 \mathrm{E}-05$ \\
t Critical one-tail & 1.859548038
\end{tabular}

$\mathrm{G}_{\text {sa }}$

t-Test: Two-Sample Assuming Equal Variances

\begin{tabular}{lrr}
\hline & Variable 1 & Variable 2 \\
\hline Mean & 2.7081703 & 2.7080004 \\
Variance & $5.164 \mathrm{E}-06$ & $1.056 \mathrm{E}-05$ \\
Observations & 5 & 5
\end{tabular}

Pooled Variance 7.861E-06

Hypothesized Mean

Difference 0

df

t Stat

0.0958155

$\mathrm{P}(\mathrm{T}<=\mathrm{t})$ one-tail $\quad 0.4630119$

$\mathrm{t}$ Critical one-tail $\quad 1.859548$

$\mathrm{P}(\mathrm{T}<=\mathrm{t})$ two-tail $\quad 0.9260238$

$\mathrm{t}$ Critical two-tail $\quad 2.3060041$

Decision cannot reject Ho

$\mathrm{G}_{\mathrm{sa}}$

t-Test: Two-Sample Assuming Equal Variances

\begin{tabular}{lrr}
\hline & Variable 1 & Variable 2 \\
\hline Mean & 2.7078816 & 2.7080004 \\
Variance & $1.15 \mathrm{E}-05$ & $1.056 \mathrm{E}-05$ \\
Observations & 5 & 5 \\
Pooled Variance & $1.103 \mathrm{E}-05$ & \\
Hypothesized Mean & & \\
Difference & 0 & \\
df & 8 & \\
$\mathrm{t}$ Stat & - & \\
$\mathrm{P}(\mathrm{T}<=\mathrm{t})$ one-tail & 0.0565353 & \\
$\mathrm{t}$ Critical one-tail & 0.478151 &
\end{tabular}




\begin{tabular}{|c|c|c|c|c|c|}
\hline $\mathrm{P}(\mathrm{T}<=\mathrm{t})$ two-tail & $2.0845 \mathrm{E}-07$ & $\mathrm{P}(\mathrm{T}<=\mathrm{t})$ two-tail & $6.15077 \mathrm{E}-05$ & $\mathrm{P}(\mathrm{T}<=\mathrm{t})$ two-tail & 0.9563019 \\
\hline t Critical two-tail & 2.30600414 & t Critical two-tail & 2.306004135 & t Critical two-tail & 2.3060041 \\
\hline Decision & reject Ho & Decision & reject Ho & Decision & cannot reject Ho \\
\hline
\end{tabular}

Wisconsin Method vs Provisional Cone test

t-Test: Two-Sample Assuming Equal Variances

\begin{tabular}{lrr}
\hline & Variable 1 & Variable 2 \\
\hline Mean & 2.66234141 & 2.6372963 \\
Variance & $5.3837 \mathrm{E}-05$ & $1.426 \mathrm{E}-06$ \\
Observations & 5 & 5 \\
Pooled Variance & $2.7631 \mathrm{E}-05$ & \\
Hypothesized Mean & & \\
Difference & 0 & \\
df & 8 & \\
$\mathrm{t}$ Stat & 7.53340693 & \\
$\mathrm{P}(\mathrm{T}<=\mathrm{t})$ one-tail & $3.3562 \mathrm{E}-05$ & \\
$\mathrm{t}$ Critical one-tail & 1.85954804 & \\
$\mathrm{P}(\mathrm{T}<=\mathrm{t})$ two-tail & $6.7124 \mathrm{E}-05$ & \\
$\mathrm{t}$ Critical two-tail & 2.30600414 & \\
\hline
\end{tabular}

Decision

reject $\mathrm{Ho}$

Corelok Method vs Provisional Cone test

$\mathrm{G}_{\mathrm{sb}}$

t-Test: Two-Sample Assuming Equal Variances

\begin{tabular}{lrr}
\hline & Variable 1 & Variable 2 \\
\hline Mean & 2.6438 & 2.6372963 \\
Variance & $1.57 \mathrm{E}-05$ & $1.426 \mathrm{E}-06$ \\
Observations & 5 & 5 \\
Pooled Variance & $8.5628 \mathrm{E}-06$ &
\end{tabular}

\% Absorption

t-Test: Two-Sample Assuming Equal Variances

\begin{tabular}{lrr}
\hline & Variable 1 & Variable 2 \\
\hline Mean & 0.618462913 & 0.98996696 \\
Variance & 0.005839103 & 0.00147868 \\
Observations & 5 & 5 \\
Pooled Variance & 0.00365889 & \\
Hypothesized Mean & 0 & \\
Difference & 8 & \\
df & & \\
t Stat & -9.71088674 & \\
P(T<=t) one-tail & $5.28106 \mathrm{E}-06$ & \\
t Critical one-tail & 1.859548038 & \\
P(T<=t) two-tail & $1.05621 \mathrm{E}-05$ & \\
t Critical two-tail & 2.306004135 & \\
\hline Decision & reject Ho &
\end{tabular}

\% Absorption

t-Test: Two-Sample Assuming Equal Variances

\begin{tabular}{lrr}
\hline & Variable 1 & Variable 2 \\
\hline Mean & 0.837 & 0.98996696 \\
Variance & 0.0037905 & 0.00147868 \\
Observations & 5 & 5 \\
Pooled Variance & 0.002634588 &
\end{tabular}

$\mathrm{G}_{\text {sa }}$

t-Test: Two-Sample Assuming Equal Variances

\begin{tabular}{lrr}
\hline & Variable 1 & Variable 2 \\
\hline Mean & 2.7068979 & 2.7080004 \\
Variance & $7.623 \mathrm{E}-06$ & $1.056 \mathrm{E}-05$ \\
Observations & 5 & 5 \\
Pooled Variance & $9.091 \mathrm{E}-06$ & \\
Hypothesized Mean & & \\
Difference & 0 \\
$\mathrm{df}$ & \multicolumn{2}{c}{-} \\
$\mathrm{t}$ Stat & - \\
$\mathrm{P}(\mathrm{T}<=\mathrm{t})$ one-tail & 0.5781495 \\
$\mathrm{t}$ Critical one-tail & 0.2895349 \\
$\mathrm{P}(\mathrm{T}<=\mathrm{t})$ two-tail & 1.859548 \\
$\mathrm{t}$ Critical two-tail & 0.5790698 \\
\hline Decision & 2.3060041 \\
\hline \multicolumn{2}{|c}{ cannot reject Ho }
\end{tabular}

$\mathrm{G}_{\mathrm{sa}}$

t-Test: Two-Sample Assuming Equal Variances

\begin{tabular}{lrr}
\hline & Variable 1 & Variable 2 \\
\hline Mean & 2.7034 & 2.7080004 \\
Variance & $2.3 \mathrm{E}-06$ & $1.056 \mathrm{E}-05$ \\
Observations & 5 & 5 \\
Pooled Variance & $6.429 \mathrm{E}-06$ &
\end{tabular}




\begin{tabular}{|c|c|c|c|c|c|}
\hline Hypothesized Mean & & Hypothesized Mean & & Hypothesized Mear & \\
\hline Difference & 0 & Difference & 0 & Difference & 0 \\
\hline df & 8 & $\mathrm{df}$ & 8 & $\mathrm{df}$ & 8 \\
\hline t Stat & 3.51414657 & t Stat & -4.71206507 & t Stat & 2.8686461 \\
\hline $\mathrm{P}(\mathrm{T}<=\mathrm{t})$ one-tail & 0.0039567 & $\mathrm{P}(\mathrm{T}<=\mathrm{t})$ one-tail & 0.000758812 & $\mathrm{P}(\mathrm{T}<=\mathrm{t})$ one-tail & 0.0104361 \\
\hline t Critical one-tail & 1.85954804 & t Critical one-tail & 1.859548038 & t Critical one-tail & 1.859548 \\
\hline $\mathrm{P}(\mathrm{T}<=\mathrm{t})$ two-tail & 0.0079134 & $\mathrm{P}(\mathrm{T}<=\mathrm{t})$ two-tail & 0.001517624 & $\mathrm{P}(\mathrm{T}<=\mathrm{t})$ two-tail & 0.0208723 \\
\hline Decision & reject Ho & Decision & reject Ho & Decision & reject Ho \\
\hline
\end{tabular}

lowa Method vs Provisional Cone Test

$\mathrm{G}_{\mathrm{sb}}$

t-Test: Two-Sample Assuming Equal Variances

\begin{tabular}{lrr} 
& Variable 1 & Variable 2 \\
\hline Mean & 2.63185445 & 2.6372963 \\
Variance & $1.1718 \mathrm{E}-05$ & $1.426 \mathrm{E}-06$ \\
Observations & 5 & 5 \\
Pooled Variance & $6.5719 \mathrm{E}-06$ & \\
Hypothesized Mean & 0 & \\
Difference & 8 & \\
df & & \\
t Stat & -3.3564003 & \\
$\mathrm{P}(\mathrm{T}<=\mathrm{t})$ one-tail & 0.00499249 & \\
$\mathrm{t}$ Critical one-tail & 1.85954804 & \\
$\mathrm{P}(\mathrm{T}<=\mathrm{t})$ two-tail & 0.00998498 & \\
$\mathrm{t}$ Critical two-tail & 2.30600414 & \\
\hline
\end{tabular}

Decision

reject Ho

Texas Method vs Provisional Cone Test$$
\mathrm{G}_{\mathrm{sb}}
$$

t-Test: Two-Sample Assuming Equal Variances
$\%$ Absorption

t-Test: Two-Sample Assuming Equal Variances

\begin{tabular}{lrr}
\hline & Variable 1 & Variable 2 \\
\hline Mean & 1.033838337 & 0.98996696 \\
Variance & 0.000415527 & 0.00147868 \\
Observations & 5 & 5 \\
Pooled Variance & 0.000947101 & \\
Hypothesized Mean & 0 & \\
Difference & 8 & \\
df & & \\
t Stat & 2.253995236 & \\
$\mathrm{P}(\mathrm{T}<=\mathrm{t})$ one-tail & 0.02711408 & \\
$\mathrm{t}$ Critical one-tail & 1.859548038 & \\
$\mathrm{P}(\mathrm{T}<=\mathrm{t})$ two-tail & 0.054228159 & \\
$\mathrm{t}$ Critical two-tail & 2.306004135 & \\
\hline Decision & cannot reject Ho
\end{tabular}

$\%$ Absorption

t-Test: Two-Sample Assuming Equal Variances
$\mathrm{G}_{\mathrm{sa}}$

t-Test: Two-Sample Assuming Equal Variances

\begin{tabular}{lrr}
\hline & Variable 1 & Variable 2 \\
\hline Mean & 2.7054668 & 2.7080004 \\
Variance & $9.217 \mathrm{E}-06$ & $1.056 \mathrm{E}-05$ \\
Observations & 5 & 5
\end{tabular}

Pooled Variance $\quad 9.888 \mathrm{E}-06$

Hypothesized Mean

Difference 0

df

t Stat 1.2739393

$\mathrm{P}(\mathrm{T}<=\mathrm{t})$ one-tail $\quad 0.1192233$

$\mathrm{t}$ Critical one-tail $\quad 1.859548$

$\mathrm{P}(\mathrm{T}<=\mathrm{t})$ two-tail $\quad 0.2384465$

$\mathrm{t}$ Critical two-tail $\quad 2.3060041$

Decision cannot reject $\mathrm{Ho}$

$\mathrm{G}_{\mathrm{sa}}$

t-Test: Two-Sample Assuming Equal Variances 


\begin{tabular}{|c|c|c|}
\hline & Variable 1 & Variable 2 \\
\hline Mean & 2.64190449 & 2.6372963 \\
\hline Variance & $1.158 \mathrm{E}-05$ & 1.426E-06 \\
\hline Observations & 5 & 5 \\
\hline $\begin{array}{l}\text { Pooled Variance } \\
\text { Hypothesized Mean } \\
\text { Difference }\end{array}$ & $6.503 \mathrm{E}-06$ & \\
\hline $\mathrm{df}$ & 8 & \\
\hline t Stat & 2.85720336 & \\
\hline $\mathrm{P}(\mathrm{T}<=\mathrm{t})$ one-tail & 0.01062126 & \\
\hline t Critical one-tail & 1.85954804 & \\
\hline$P(T<=t)$ two-tail & 0.02124252 & \\
\hline t Critical two-tail & 2.30600414 & \\
\hline Decision & reject Ho & \\
\hline \multicolumn{3}{|c|}{ California Test 225 vs Provisional Cone Test } \\
\hline \multicolumn{3}{|c|}{ t-Test: Two-Sample Assuming Equal Variances } \\
\hline & Variable 1 & Variable 2 \\
\hline Mean & 2.63329849 & 2.6372963 \\
\hline Variance & $9.135 \mathrm{E}-06$ & $1.426 \mathrm{E}-06$ \\
\hline Observations & 5 & 5 \\
\hline $\begin{array}{l}\text { Pooled Variance } \\
\text { Hypothesized Mean }\end{array}$ & $5.2803 \mathrm{E}-06$ & \\
\hline Difference & 0 & \\
\hline df & 8 & \\
\hline t Stat & -2.7508317 & \\
\hline $\mathrm{P}(\mathrm{T}<=\mathrm{t})$ one-tail & 0.01251337 & \\
\hline t Critical one-tail & 1.85954804 & \\
\hline $\mathrm{P}(\mathrm{T}<=\mathrm{t})$ two-tail & 0.02502674 & \\
\hline t Critical two-tail & 2.30600414 & \\
\hline Decision & reject Ho & \\
\hline
\end{tabular}

\begin{tabular}{lrr} 
& Variable 1 & Variable 2 \\
\hline Mean & 1.051588395 & 0.98996696 \\
Variance & 0.007577714 & 0.00147868 \\
Observations & 5 & 5 \\
Pooled Variance & 0.004528195 & \\
Hypothesized Mean & 0 & \\
Difference & 8 \\
df & 1.447902222 \\
t Stat & 0.092836434 \\
P(T<=t) one-tail & 1.859548038 \\
t Critical one-tail & 0.185672868 \\
P(T<=t) two-tail & 2.306004135 & \\
t Critical two-tail & cannot reject Ho
\end{tabular}

\begin{tabular}{lrr}
\hline & Variable 1 & Variable 2 \\
\hline Mean & 2.7094727 & 2.7080004 \\
Variance & $1.459 \mathrm{E}-05$ & $1.056 \mathrm{E}-05$ \\
Observations & 5 & 5 \\
Pooled Variance & $1.257 \mathrm{E}-05$ & \\
Hypothesized Mean & \multicolumn{2}{c}{0} \\
Difference & \multicolumn{2}{|c}{} \\
$\mathrm{df}$ & 0.6565259 \\
$\mathrm{t}$ Stat & 0.2649568 \\
$\mathrm{P}(\mathrm{T}<=\mathrm{t})$ one-tail & 1.859548 \\
$\mathrm{t}$ Critical one-tail & 0.5299136 \\
$\mathrm{P}(\mathrm{T}<=\mathrm{t})$ two-tail & 2.3060041 & \\
$\mathrm{t}$ Critical two-tail & cannot reject Ho
\end{tabular}

\% Absorption

$\mathrm{G}_{\mathrm{sa}}$

$\mathrm{t}$-Test: Two-Sample Assuming Equal Variances $\quad$ t-Test: Two-Sample Assuming Equal Variances

\begin{tabular}{|c|c|c|c|c|c|}
\hline & Variable 1 & Variable 2 & & Variable 1 & Variable 2 \\
\hline Mean & 1.097871659 & 0.98996696 & Mean & 2.711692 & 2.7080004 \\
\hline Variance & 0.000986974 & 0.00147868 & Variance & $2.569 \mathrm{E}-06$ & 1.056E-05 \\
\hline Observations & 5 & 5 & Observations & 5 & 5 \\
\hline Pooled Variance & 0.001232825 & & Pooled Variance & $6.564 \mathrm{E}-06$ & \\
\hline Difference & 0 & & Difference & 0 & \\
\hline$d f$ & 8 & & $\mathrm{df}$ & 8 & \\
\hline t Stat & 4.85914222 & & t Stat & 2.2782553 & \\
\hline $\mathrm{P}(\mathrm{T}<=\mathrm{t})$ one-tail & 0.000628586 & & $\mathrm{P}(\mathrm{T}<=\mathrm{t})$ one-tail & 0.0261067 & \\
\hline t Critical one-tail & 1.859548038 & & t Critical one-tail & 1.859548 & \\
\hline $\mathrm{P}(\mathrm{T}<=\mathrm{t})$ two-tail & 0.001257171 & & $\mathrm{P}(\mathrm{T}<=\mathrm{t})$ two-tail & 0.0522133 & \\
\hline t Critical two-tail & 2.306004135 & & t Critical two-tail & 2.3060041 & \\
\hline Decision & ject $\mathrm{Ho}$ & & Decision & cannot rej & Ho \\
\hline
\end{tabular}


Hard Paper Method vs Provisional Surface test

$\mathrm{G}_{\mathrm{sb}}$

t-Test: Two-Sample Assuming Equal Variances

\begin{tabular}{lrr}
\hline & Variable 1 & Variable 2 \\
\hline Mean & 2.62985917 & 2.6255572 \\
Variance & $4.4281 \mathrm{E}-05$ & $1.456 \mathrm{E}-05$ \\
Observations & 5 & 5 \\
Pooled Variance & $2.9419 \mathrm{E}-05$ & \\
Hypothesized Mean & 0 \\
Difference & 8 \\
df & \\
$\mathrm{t}$ Stat & 1.25407948 \\
$\mathrm{P}(\mathrm{T}<=\mathrm{t})$ one-tail & 0.12260781 \\
$\mathrm{t}$ Critical one-tail & 1.85954804 \\
$\mathrm{P}(\mathrm{T}<=\mathrm{t})$ two-tail & 0.24521561 \\
$\mathrm{t}$ Critical two-tail & 2.30600414 & \\
\hline Decision & \multicolumn{2}{|c}{ cannot reject Ho }
\end{tabular}

Arizona DOT Method vs Provisional Surface test

$\mathrm{G}_{\mathrm{sb}}$

t-Test: Two-Sample Assuming Equal Variances

\begin{tabular}{lrr}
\hline & Variable 1 & Variable 2 \\
\hline Mean & 2.61774436 & 2.6255572 \\
Variance & $5.8268 \mathrm{E}-06$ & $1.456 \mathrm{E}-05$ \\
Observations & 5 & 5 \\
Pooled Variance & $1.0192 \mathrm{E}-05$ & \\
Hypothesized Mean & & \\
Difference & 0 & \\
df & 8 & \\
tStat & -3.8694704 &
\end{tabular}

\% Absorption

t-Test: Two-Sample Assuming Equal Variances

\begin{tabular}{lrr} 
& \multicolumn{1}{c}{ Variable 1 } & Variable 2 \\
\hline Mean & 1.099723816 & 1.19283672 \\
Variance & 0.008399526 & 0.00127489 \\
Observations & 5 & 5 \\
Pooled Variance & 0.004837209 & \\
Hypothesized Mean & & \\
Difference & 0 & \\
df & 8 &
\end{tabular}

\begin{tabular}{lc}
$\mathrm{t}$ Stat & -2.11681293 \\
$\mathrm{P}(\mathrm{T}<=\mathrm{t})$ one-tail & 0.03357875 \\
$\mathrm{t}$ Critical one-tail & 1.859548038 \\
$\mathrm{P}(\mathrm{T}<=\mathrm{t})$ two-tail & 0.0671575 \\
$\mathrm{t}$ Critical two-tail & 2.306004135 \\
\hline Decision & cannot reject Ho
\end{tabular}

$\mathrm{G}_{\mathrm{sa}}$

t-Test: Two-Sample Assuming Equal Variances

\begin{tabular}{lrr}
\hline & Variable 1 & Variable 2 \\
\hline Mean & 2.7081703 & 2.7104439 \\
Variance & $5.164 \mathrm{E}-06$ & $1.398 \mathrm{E}-05$ \\
Observations & 5 & 5 \\
Pooled Variance & $9.57 \mathrm{E}-06$ \\
Hypothesized Mean & & \\
Difference & 0 \\
df & 8 \\
t Stat & - \\
$\mathrm{P}(\mathrm{T}<=\mathrm{t})$ one-tail & 1.1620956 \\
$\mathrm{t}$ Critical one-tail & 0.1393453 \\
$\mathrm{P}(\mathrm{T}<=\mathrm{t})$ two-tail & 1.859548 \\
$\mathrm{t}$ Critical two-tail & 0.2786905 \\
\hline Decision & 2.3060041 \\
\hline \multicolumn{2}{c}{ cannot reject Ho }
\end{tabular}

\% Absorption

t-Test: Two-Sample Assuming Equal Variances

\begin{tabular}{lrr}
\hline & Variable 1 & Variable 2 \\
\hline Mean & 1.271570538 & 1.19283672 \\
Variance & 0.00533844 & 0.00127489 \\
Observations & 5 & 5 \\
Pooled Variance & 0.003306666 & \\
Hypothesized Mean & & \\
Difference & 0 & \\
df & 8 &
\end{tabular}

2.164891629

$\mathrm{G}_{\mathrm{sa}}$

t-Test: Two-Sample Assuming Equal Variances

\begin{tabular}{lrr}
\hline & Variable 1 & Variable 2 \\
\hline Mean & 2.7078816 & 2.7104439 \\
Variance & $1.15 \mathrm{E}-05$ & $1.398 \mathrm{E}-05$ \\
Observations & 5 & 5 \\
Pooled Variance & $1.274 \mathrm{E}-05$ & \\
Hypothesized Mean & & \\
Difference & 0 & \\
df & 8 &
\end{tabular}

t Stat

$-1.135078$ 


\begin{tabular}{|c|c|c|c|c|c|}
\hline $\mathrm{P}(\mathrm{T}<=\mathrm{t})$ one-tail & 0.00237245 & $\mathrm{P}(\mathrm{T}<=\mathrm{t})$ one-tail & 0.031156309 & $\mathrm{P}(\mathrm{T}<=\mathrm{t})$ one-tail & 0.144602 \\
\hline t Critical one-tail & 1.85954804 & t Critical one-tail & 1.859548038 & t Critical one-tail & 1.859548 \\
\hline $\mathrm{P}(\mathrm{T}<=\mathrm{t})$ two-tail & 0.0047449 & $\mathrm{P}(\mathrm{T}<=\mathrm{t})$ two-tail & 0.062312619 & $\mathrm{P}(\mathrm{T}<=\mathrm{t})$ two-tail & 0.289204 \\
\hline
\end{tabular}

Wisconsin Method vs Provisional Surface test

t-Test: Two-Sample Assuming Equal Variances

\begin{tabular}{lrr}
\hline & Variable 1 & Variable 2 \\
\hline Mean & 2.66234141 & 2.6255572 \\
Variance & $5.3837 \mathrm{E}-05$ & $1.456 \mathrm{E}-05$ \\
Observations & 5 & 5 \\
Pooled Variance & $3.4197 \mathrm{E}-05$ & \\
Hypothesized Mean & & \\
Difference & 0 & \\
df & 8 & \\
$\mathrm{t}$ Stat & 9.94575369 & \\
$\mathrm{P}(\mathrm{T}<=\mathrm{t})$ one-tail & $4.4199 \mathrm{E}-06$ & \\
$\mathrm{t}$ Critical one-tail & 1.85954804 & \\
$\mathrm{P}(\mathrm{T}<=\mathrm{t})$ two-tail & $8.8399 \mathrm{E}-06$ & \\
$\mathrm{t}$ Critical two-tail & 2.30600414 & \\
\hline Decision & reject Ho
\end{tabular}

Corelok Method vs Provisional Surface test

$\mathrm{G}_{\mathrm{sb}}$

t-Test: Two-Sample Assuming Equal Variances

\begin{tabular}{lrc} 
& Variable 1 & Variable 2 \\
\hline Mean & 2.6438 & 2.6372963 \\
Variance & $1.57 \mathrm{E}-05$ & $1.426 \mathrm{E}-06$
\end{tabular}

\% Absorption

t-Test: Two-Sample Assuming Equal Variances

\begin{tabular}{lrr} 
& Variable 1 & Variable 2 \\
\hline Mean & 0.618462913 & 1.19283672 \\
Variance & 0.005839103 & 0.00127489 \\
Observations & 5 & 5 \\
Pooled Variance & 0.003556997 & \\
Hypothesized Mean & 0 & \\
Difference & 8 & \\
df & & \\
t Stat & -15.2272989 & \\
P(T<=t) one-tail & $1.71458 E-07$ & \\
t Critical one-tail & 1.859548038 & \\
P(T<=t) two-tail & $3.42916 \mathrm{E}-07$ & \\
t Critical two-tail & 2.306004135 & \\
\hline Decision & reject Ho
\end{tabular}

\% Absorption

t-Test: Two-Sample Assuming Equal Variances

\begin{tabular}{lrc} 
& Variable 1 & Variable 2 \\
\hline Mean & 0.837 & 1.19283672 \\
Variance & 0.0037905 & 0.00127489
\end{tabular}

t-Test: Two-Sample Assuming Equal Variances

\begin{tabular}{lrr}
\hline & Variable 1 & Variable 2 \\
\hline Mean & 2.7068979 & 2.7104439 \\
Variance & $7.623 \mathrm{E}-06$ & $1.398 \mathrm{E}-05$ \\
Observations & 5 & 5 \\
Pooled Variance & $1.08 \mathrm{E}-05$ & \\
Hypothesized Mean & & \\
Difference & 0 \\
$\mathrm{df}$ & 8 \\
$\mathrm{t}$ Stat & - \\
$\mathrm{P}(\mathrm{T}<=\mathrm{t})$ one-tail & 1.7061279 \\
$\mathrm{t}$ Critical one-tail & 0.0631875 \\
$\mathrm{P}(\mathrm{T}<=\mathrm{t})$ two-tail & 1.859548 \\
$\mathrm{t}$ Critical two-tail & 0.1263749 & \\
\hline Decision & 2.3060041 &
\end{tabular}

$\mathrm{G}_{\mathrm{sa}}$

t-Test: Two-Sample Assuming Equal Variances

\begin{tabular}{lrc}
\hline & Variable 1 & Variable 2 \\
\hline Mean & 2.7034 & 2.7104439 \\
Variance & $2.3 \mathrm{E}-06$ & $1.398 \mathrm{E}-05$
\end{tabular}




\begin{tabular}{|c|c|c|c|c|c|c|c|c|}
\hline Observations & 5 & 5 & Observations & 5 & 5 & Observations & 5 & 5 \\
\hline $\begin{array}{l}\text { Pooled Variance } \\
\text { Hypothesized Mean }\end{array}$ & $8.5628 \mathrm{E}-06$ & & $\begin{array}{l}\text { Pooled Variance } \\
\text { Hypothesized Mean }\end{array}$ & 0.002532695 & & Pooled Variance & $8.138 \mathrm{E}-06$ & \\
\hline Difference & 0 & & Difference & 0 & & $\begin{array}{l}\text { Hypotnesized Ivean } \\
\text { Difference }\end{array}$ & 0 & \\
\hline df & 8 & & df & 8 & & df & 8 & \\
\hline t Stat & 3.51414657 & & t Stat & -11.1796777 & & $\mathrm{t}$ Stat & 3.9041262 & \\
\hline $\mathrm{P}(\mathrm{T}<=\mathrm{t})$ one-tail & 0.0039567 & & $\mathrm{P}(\mathrm{T}<=\mathrm{t})$ one-tail & $1.83528 \mathrm{E}-06$ & & $\mathrm{P}(\mathrm{T}<=\mathrm{t})$ one-tail & 0.0022591 & \\
\hline$P(T<=t)$ two-tail & 0.0079134 & & $\mathrm{P}(\mathrm{T}<=\mathrm{t})$ two-tail & $3.67056 \mathrm{E}-06$ & & $\mathrm{P}(\mathrm{T}<=\mathrm{t})$ two-tail & 0.0045183 & \\
\hline t Critical two-tail & 2.30600414 & & t Critical two-tail & 2.306004135 & & t Critical two-tail & 2.3060041 & \\
\hline Decision & reject Ho & & Decision & reject Ho & & Decision & reject Ho & \\
\hline \multicolumn{9}{|c|}{ lowa Method vs Provisional Surface Test } \\
\hline \multicolumn{3}{|c|}{$\begin{array}{l}\mathrm{G}_{\mathrm{sb}} \\
\mathrm{t} \text {-Test: Two-Sample Assuming Equal Variances }\end{array}$} & \% Absorption & & & \multicolumn{3}{|l|}{$\mathrm{G}_{\mathrm{sa}}$} \\
\hline & Variable 1 & Variable 2 & & Variable 1 & Variable 2 & & Variable 1 & Variable 2 \\
\hline Mean & 2.63185445 & 2.6255572 & Mean & 1.033838337 & 1.19283672 & Mean & 2.7054668 & 2.7104439 \\
\hline Variance & $1.1718 \mathrm{E}-05$ & $1.456 \mathrm{E}-05$ & Variance & 0.000415527 & 0.00127489 & Variance & $9.217 \mathrm{E}-06$ & $1.398 \mathrm{E}-05$ \\
\hline Observations & 5 & 5 & Observations & 5 & 5 & Observations & 5 & 5 \\
\hline $\begin{array}{l}\text { Pooled Variance } \\
\text { Hypothesized Mean }\end{array}$ & $1.3138 \mathrm{E}-05$ & & $\begin{array}{l}\text { Pooled Variance } \\
\text { Hypothesized Mean }\end{array}$ & 0.000845209 & & $\begin{array}{l}\text { Pooled Variance } \\
\text { Hypothesized Mean }\end{array}$ & $1.16 \mathrm{E}-05$ & \\
\hline Difference & 0 & & Difference & 0 & & Difference & 0 & \\
\hline$d f$ & 8 & & $d f$ & 8 & & $d f$ & 8 & \\
\hline t Stat & 2.74703988 & & $\mathrm{t}$ Stat & -8.6473037 & & t Stat & 2.3109099 & \\
\hline $\mathrm{P}(\mathrm{T}<=\mathrm{t})$ one-tail & 0.01258691 & & $\mathrm{P}(\mathrm{T}<=\mathrm{t})$ one-tail & $1.24192 \mathrm{E}-05$ & & $\mathrm{P}(\mathrm{T}<=\mathrm{t})$ one-tail & 0.0248093 & \\
\hline t Critical one-tail & 1.85954804 & & t Critical one-tail & 1.859548038 & & t Critical one-tail & 1.859548 & \\
\hline $\mathrm{P}(\mathrm{T}<=\mathrm{t})$ two-tail & 0.02517381 & & $\mathrm{P}(\mathrm{T}<=\mathrm{t})$ two-tail & $2.48384 \mathrm{E}-05$ & & $P(T<=t)$ two-tail & 0.0496186 & \\
\hline t Critical two-tail & 2.30600414 & & t Critical two-tail & 2.306004135 & & t Critical two-tail & 2.3060041 & \\
\hline
\end{tabular}

Texas Method vs Provisional Surface Test 
$G_{s b}$

\begin{tabular}{lrr} 
t-Test: Two-Sample Assuming Equal Variances \\
\hline & Variable 1 & Variable 2 \\
\hline Mean & 2.64190449 & 2.6255572 \\
Variance & $1.158 \mathrm{E}-05$ & $1.456 \mathrm{E}-05$ \\
Observations & 5 & 5 \\
Pooled Variance & $1.3069 \mathrm{E}-05$ & \\
Hypothesized Mean & 0 & \\
Difference & 8 & \\
df & & \\
t Stat & 7.1499203 & \\
$\mathrm{P}(\mathrm{T}<=\mathrm{t})$ one-tail & $4.855 \mathrm{E}-05$ & \\
$\mathrm{t}$ Critical one-tail & 1.85954804 & \\
$\mathrm{P}(\mathrm{T}<=\mathrm{t})$ two-tail & $9.71 \mathrm{E}-05$ & \\
$\mathrm{t}$ Critical two-tail & 2.30600414 & \\
\hline
\end{tabular}

Decision

reject $\mathrm{Ho}$

California Test 225 vs Provisional Surface Test

$\mathrm{G}_{\mathrm{sb}}$

t-Test: Two-Sample Assuming Equal Variances

\begin{tabular}{lrr} 
& Variable 1 & Variable 2 \\
\hline Mean & 2.63329849 & 2.6255572 \\
Variance & $9.135 \mathrm{E}-06$ & $1.456 \mathrm{E}-05$ \\
Observations & 5 & 5 \\
Pooled Variance & $1.1846 \mathrm{E}-05$ & \\
Hypothesized Mean & 0 & \\
Difference & 8 & \\
df & 3.55630076 & \\
t Stat & 0.00372037 & \\
P(T<=t) one-tail & 1.85954804 & \\
t Critical one-tail &
\end{tabular}

$\%$ Absorption

t-Test: Two-Sample Assuming Equal Variances

\begin{tabular}{lrr}
\hline & Variable 1 & Variable 2 \\
\hline Mean & 1.051588395 & 1.19283672 \\
Variance & 0.007577714 & 0.00127489 \\
Observations & 5 & 5
\end{tabular}

Pooled Variance $\quad 0.004426302$

Hypothesized Mean

Difference

t Stat

$\mathrm{P}(\mathrm{T}<=\mathrm{t})$ one-tai

$\mathrm{t}$ Critical one-tail

$\mathrm{P}(\mathrm{T}<=\mathrm{t})$ two-tail

t Critical two-tail

Decision

2.306004135

reject Ho

$-3.35685659$

0.004989109

1.859548038

0.009978218

\% Absorption

t-Test: Two-Sample Assuming Equal Variances

\begin{tabular}{lrr}
\hline & Variable 1 & Variable 2 \\
\hline Mean & 1.097871659 & 1.19283672 \\
Variance & 0.000986974 & 0.00127489 \\
Observations & 5 & 5 \\
Pooled Variance & 0.001130932 & \\
Hypothesized Mean & 0 & \\
Difference & 8 & \\
df & -4.46493903 & \\
t Stat & 0.001048634 & \\
P(T<=t) one-tail & 1.859548038 & \\
t Critical one-tail &
\end{tabular}

$\mathrm{G}_{\text {sa }}$

t-Test: Two-Sample Assuming Equal Variances

\begin{tabular}{lrr} 
& Variable 1 & Variable 2 \\
\hline Mean & 2.7094727 & 2.7104439 \\
Variance & $1.459 \mathrm{E}-05$ & $1.398 \mathrm{E}-05$ \\
Observations & 5 & 5
\end{tabular}

Pooled Variance $\quad 1.428 \mathrm{E}-05$

Hypothesized Mean

Difference 0

df

t Stat

0.4063638

$\mathrm{P}(\mathrm{T}<=\mathrm{t})$ one-tail $\quad 0.3475644$

$\mathrm{t}$ Critical one-tail $\quad 1.859548$

$\mathrm{P}(\mathrm{T}<=\mathrm{t})$ two-tail $\quad 0.6951287$

$\mathrm{t}$ Critical two-tail $\quad 2.3060041$

Decision cannot reject $\mathrm{Ho}$

$\mathrm{G}_{\text {sa }}$

t-Test: Two-Sample Assuming Equal Variances

\begin{tabular}{lrr} 
& Variable 1 & Variable 2 \\
\hline Mean & 2.711692 & 2.7104439 \\
Variance & $2.569 \mathrm{E}-06$ & $1.398 \mathrm{E}-05$ \\
Observations & 5 & 5 \\
Pooled Variance & $8.273 \mathrm{E}-06$ & \\
Hypothesized Mean & 0 & \\
Difference & 8 & \\
df & 0.6861017 & \\
t Stat & 0.2560196 & \\
$\mathrm{P}(\mathrm{T}<=\mathrm{t})$ one-tail & 1.859548 & \\
$\mathrm{t}$ Critical one-tail &
\end{tabular}




\begin{tabular}{|c|c|c|c|c|c|}
\hline $\mathrm{P}(\mathrm{T}<=\mathrm{t})$ two-tail & 0.00744074 & $\mathrm{P}(\mathrm{T}<=\mathrm{t})$ two-tail & 0.002097267 & $\mathrm{P}(\mathrm{T}<=\mathrm{t})$ two-tail & 0.5120393 \\
\hline t Critical two-tail & 2.30600414 & t Critical two-tail & 2.306004135 & t Critical two-tail & 2.3060041 \\
\hline Decision & reject Ho & Decision & reject Ho & Decision & cannot reject Ho \\
\hline
\end{tabular}

Arizona DOT Method vs Hard Paper Method

t-Test: Two-Sample Assuming Equal Variances

\begin{tabular}{lrr}
\hline & Variable 1 & Variable 2 \\
\hline Mean & 2.61774436 & 2.6298592 \\
Variance & $5.8268 \mathrm{E}-06$ & $4.428 \mathrm{E}-05$ \\
Observations & 5 & 5 \\
Pooled Variance & $2.5054 \mathrm{E}-05$ & \\
Hypothesized Mean & 0 & \\
Difference & 8 & \\
df & & \\
t Stat & -3.8269193 & \\
$\mathrm{P}(\mathrm{T}<=\mathrm{t})$ one-tail & 0.00251996 & \\
$\mathrm{t}$ Critical one-tail & 1.85954804 & \\
$\mathrm{P}(\mathrm{T}<=\mathrm{t})$ two-tail & 0.00503992 & \\
$\mathrm{t}$ Critical two-tail & 2.30600414 & \\
\hline
\end{tabular}

Decision

reject $\mathrm{Ho}$

Wisconsin Method vs Hard Paper Method

$\mathrm{G}_{\mathrm{sb}}$

t-Test: Two-Sample Assuming Equal Variances

\begin{tabular}{lrr}
\hline & Variable 1 & Variable 2 \\
\hline Mean & 2.66234141 & 2.6298592 \\
Variance & $5.3837 \mathrm{E}-05$ & $4.428 \mathrm{E}-05$ \\
Observations & 5 & 5 \\
Pooled Variance & $4.9059 \mathrm{E}-05$ &
\end{tabular}

\% Absorption

t-Test: Two-Sample Assuming Equal Variances

\begin{tabular}{lrr}
\hline & Variable 1 & Variable 2 \\
\hline Mean & 1.271570538 & 1.09972382 \\
Variance & 0.00533844 & 0.00839953 \\
Observations & 5 & 5 \\
Pooled Variance & 0.006868983 & \\
Hypothesized Mean & 0 & \\
Difference & 8 & \\
df & & \\
t Stat & 3.278423298 & \\
P(T<=t) one-tail & 0.005607094 & \\
t Critical one-tail & 1.859548038 & \\
P(T<=t) two-tail & 0.011214188 & \\
t Critical two-tail & 2.306004135 & \\
\hline Decision & reject Ho
\end{tabular}

Decision

\% Absorption

$\mathrm{t}$-Test: Two-Sample Assuming Equal Variances

\begin{tabular}{lrr}
\hline & Variable 1 & Variable 2 \\
\hline Mean & 0.618462913 & 1.09972382 \\
Variance & 0.005839103 & 0.00839953 \\
Observations & 5 & 5 \\
Pooled Variance & 0.007119315 &
\end{tabular}

$\mathrm{G}_{\mathrm{sa}}$

t-Test: Two-Sample Assuming Equal Variances

\begin{tabular}{lrr}
\hline & Variable 1 & Variable 2 \\
\hline Mean & 2.7078816 & 2.7081703 \\
Variance & $1.15 \mathrm{E}-05$ & $5.164 \mathrm{E}-06$ \\
Observations & 5 & 5
\end{tabular}

Pooled Variance $\quad 8.333 \mathrm{E}-06$

Hypothesized Mean

Difference 0

df

t Sta

0.1581076

$\mathrm{P}(\mathrm{T}<=\mathrm{t})$ one-tail $\quad 0.439145$

t Critical one-tail $\quad 1.859548$

$\mathrm{P}(\mathrm{T}<=\mathrm{t})$ two-tail $\quad 0.8782901$

$\mathrm{t}$ Critical two-tail $\quad 2.3060041$

Decision cannot reject Ho

t-Test: Two-Sample Assuming Equal Variances

\begin{tabular}{lrr}
\multicolumn{3}{c}{ t-Test: Two-Sample Assuming Equal Variances } \\
\hline Mean & Variable 1 & Variable 2 \\
\hline Variance & 2.7068979 & 2.7081703 \\
Observations & $7.623 \mathrm{E}-06$ & $5.164 \mathrm{E}-06$ \\
Pooled Variance & 5 & 5 \\
& $6.393 \mathrm{E}-06$ &
\end{tabular}




$\begin{array}{lr}\begin{array}{l}\text { Hypothesized Mean } \\ \text { Difference }\end{array} & 0 \\ \text { df } & 8 \\ & 7.33258028 \\ \text { t Stat } & 4.0645 \mathrm{E}-05 \\ \mathrm{P}(\mathrm{T}<=\mathrm{t}) \text { one-tail } & 1.85954804 \\ \mathrm{t} \text { Critical one-tail } & 8.1291 \mathrm{E}-05 \\ \mathrm{P}(\mathrm{T}<=\mathrm{t}) \text { two-tail } & 2.30600414 \\ \mathrm{t} \text { Critical two-tail } & \text { reject } \mathrm{Ho}\end{array}$

Decision

\section{Hypothesized Mean \\ Difference}

df

t Stat

$\mathrm{P}(\mathrm{T}<=\mathrm{t})$ one-tail

$\mathrm{t}$ Critical one-tail

$\mathrm{P}(\mathrm{T}<=\mathrm{t})$ two-tail

$\mathrm{t}$ Critical two-tail

Decision
0

8

$-9.01844131$

9.12718E-06

1.859548038

$1.82544 \mathrm{E}-05$

2.306004135

reject Ho
Hypothesized Mean

Difference

df

t Stat

$\mathrm{P}(\mathrm{T}<=\mathrm{t})$ one-tail $\quad 0.2245944$

$\mathrm{t}$ Critical one-tail $\quad 1.859548$

$\mathrm{P}(\mathrm{T}<=\mathrm{t})$ two-tail $\quad 0.4491887$

$\mathrm{t}$ Critical two-tail $\quad 2.3060041$

Decision cannot reject $\mathrm{Ho}$

Corelok Method vs Hard Paper Method

t-Test: Two-Sample Assuming Equal Variances

\begin{tabular}{lrr}
\hline & Variable 1 & Variable 2 \\
\hline Mean & 2.6438 & 2.6298592 \\
Variance & $1.57 \mathrm{E}-05$ & $4.428 \mathrm{E}-05$ \\
Observations & 5 & 5 \\
Pooled Variance & $2.999 \mathrm{E}-05$ & \\
Hypothesized Mean & 0 & \\
Difference & 8 & \\
df & & \\
$t$ Stat & 4.02501199 & \\
$\mathrm{P}(\mathrm{T}<=\mathrm{t})$ one-tail & 0.00190722 & \\
$\mathrm{t}$ Critical one-tail & 1.85954804 & \\
$\mathrm{P}(\mathrm{T}<=\mathrm{t})$ two-tail & 0.00381444 & \\
$\mathrm{t}$ Critical two-tail & 2.30600414 & \\
\hline
\end{tabular}

Decision reject Ho

lowa Method vs Hard Paper Method

$\mathrm{G}_{\mathrm{sb}}$

t-Test: Two-Sample Assuming Equal Variances
\% Absorption

t-Test: Two-Sample Assuming Equal Variances

\begin{tabular}{lrr} 
& Variable 1 & Variable 2 \\
\hline Mean & 0.837 & 1.09972382 \\
Variance & 0.0037905 & 0.00839953 \\
Observations & 5 & 5 \\
Pooled Variance & 0.006095013 & \\
Hypothesized Mean & & \\
Difference & 0 & \\
df & 8 &
\end{tabular}

\begin{tabular}{ll}
$\mathrm{t}$ Stat & -5.32086354 \\
$\mathrm{P}(\mathrm{T}<=\mathrm{t})$ one-tail & 0.000355149 \\
$\mathrm{t}$ Critical one-tail & 1.859548038 \\
$\mathrm{P}(\mathrm{T}<=\mathrm{t})$ two-tail & 0.000710297 \\
$\mathrm{t}$ Critical two-tail & 2.306004135 \\
\hline Decision & reject Ho
\end{tabular}

Decision

reject Ho

\% Absorption

t-Test: Two-Sample Assuming Equal Variances
$\mathrm{G}_{\mathrm{sa}}$

t-Test: Two-Sample Assuming Equal Variances

\begin{tabular}{lrr}
\hline & Variable 1 & Variable 2 \\
\hline Mean & 2.7034 & 2.7081703 \\
Variance & $2.3 \mathrm{E}-06$ & $5.164 \mathrm{E}-06$ \\
Observations & 5 & 5 \\
Pooled Variance & $3.732 \mathrm{E}-06$ & \\
Hypothesized Mean & & \\
Difference & 0 \\
df & 8 \\
t Stat & - \\
P(T<=t) one-tail & 3.9044136 \\
t Critical one-tail & 0.0022582 \\
P(T<=t) two-tail & 1.859548 \\
t Critical two-tail & 0.0045165 \\
\hline Decision & 2.3060041 & \\
& \multicolumn{2}{|c}{} \\
\end{tabular}

$\mathrm{G}_{\mathrm{sa}}$

t-Test: Two-Sample Assuming Equal Variances 


\begin{tabular}{|c|c|c|}
\hline & Variable 1 & Variable 2 \\
\hline Mean & 2.63185445 & 2.6298592 \\
\hline Variance & $1.1718 \mathrm{E}-05$ & $4.428 \mathrm{E}-05$ \\
\hline Observations & 5 & 5 \\
\hline $\begin{array}{l}\text { Pooled Variance } \\
\text { Hypothesized Mean } \\
\text { Difference }\end{array}$ & 2.7999E-05 & \\
\hline$d f$ & 8 & \\
\hline t Stat & 0.59620917 & \\
\hline $\mathrm{P}(\mathrm{T}<=\mathrm{t})$ one-tail & 0.283759 & \\
\hline t Critical one-tail & 1.85954804 & \\
\hline $\mathrm{P}(\mathrm{T}<=\mathrm{t})$ two-tail & 0.56751799 & \\
\hline t Critical two-tail & 2.30600414 & \\
\hline Decision & cannot reject & \\
\hline \multirow{2}{*}{\multicolumn{3}{|c|}{$\mathrm{G}_{\mathrm{sb}}$}} \\
\hline & & \\
\hline & Variable 1 & Variable 2 \\
\hline Mean & 2.64190449 & 2.6298592 \\
\hline Variance & $1.158 \mathrm{E}-05$ & $4.428 \mathrm{E}-05$ \\
\hline Observations & 5 & 5 \\
\hline $\begin{array}{l}\text { Pooled Variance } \\
\text { Hypothesized Mean }\end{array}$ & $2.7931 \mathrm{E}-05$ & \\
\hline Difference & 0 & \\
\hline df & 8 & \\
\hline t Stat & 3.60369633 & \\
\hline $\mathrm{P}(\mathrm{T}<=\mathrm{t})$ one-tail & 0.00347246 & \\
\hline t Critical one-tail & 1.85954804 & \\
\hline $\mathrm{P}(\mathrm{T}<=\mathrm{t})$ two-tail & 0.00694492 & \\
\hline t Critical two-tail & 2.30600414 & \\
\hline
\end{tabular}

\begin{tabular}{lrr} 
& Variable 1 & Variable 2 \\
\hline Mean & 1.033838337 & 1.09972382 \\
Variance & 0.000415527 & 0.00839953 \\
Observations & 5 & 5 \\
Pooled Variance & 0.004407527 & \\
Hypothesized Mean & 0 \\
Difference & 8 \\
df & & \\
$t$ Stat & -1.56914198 \\
$\mathrm{P}(\mathrm{T}<=\mathrm{t})$ one-tail & 0.077626844 \\
$\mathrm{t}$ Critical one-tail & 1.859548038 \\
$\mathrm{P}(\mathrm{T}<=\mathrm{t})$ two-tail & 0.155253688 \\
$\mathrm{t}$ Critical two-tail & 2.306004135 & \\
\hline Decision & cannot reject Ho &
\end{tabular}

\begin{tabular}{lrr} 
& & \\
\hline Mean & Variable 1 & Variable 2 \\
Variance & 2.7054668 & 2.7081703 \\
Observations & $5.217 \mathrm{E}-06$ & $5.164 \mathrm{E}-06$ \\
Pooled Variance & $5.19 \mathrm{E}-06$ \\
Hypothesized Mean & & \\
Difference & 0 \\
df & 8 \\
t Stat & - \\
$\mathrm{P}(\mathrm{T}<=\mathrm{t})$ one-tail & 1.5941089 \\
$\mathrm{t}$ Critical one-tail & 0.0747888 \\
$\mathrm{P}(\mathrm{T}<=\mathrm{t})$ two-tail & 1.859548 \\
$\mathrm{t}$ Critical two-tail & 0.1495776 \\
\hline Decision & 2.3060041 & \\
\end{tabular}

\% Absorption

$\mathrm{G}_{\mathrm{sa}}$

t-Test: Two-Sample Assuming Equal Variances $\quad$ t-Test: Two-Sample Assuming Equal Variances

\begin{tabular}{|c|c|c|c|c|c|}
\hline & Variable 1 & Variable 2 & & Variable 1 & Variable 2 \\
\hline Mean & 1.051588395 & 1.09972382 & Mean & 2.7094727 & 2.7081703 \\
\hline Variance & 0.007577714 & 0.00839953 & Variance & $1.459 \mathrm{E}-05$ & $5.164 \mathrm{E}-06$ \\
\hline Observations & 5 & 5 & Observations & 5 & 5 \\
\hline $\begin{array}{l}\text { Pooled Variance } \\
\text { Hypothesized Mean }\end{array}$ & 0.00798862 & & $\begin{array}{l}\text { Pooled Variance } \\
\text { Hypothesized Mean }\end{array}$ & $9.875 \mathrm{E}-06$ & \\
\hline Difference & 0 & & Difference & 0 & \\
\hline $\mathrm{df}$ & 8 & & $\mathrm{df}$ & 8 & \\
\hline t Stat & -0.85152793 & & t Stat & 0.6553024 & \\
\hline $\mathrm{P}(\mathrm{T}<=\mathrm{t})$ one-tail & 0.209617102 & & $\mathrm{P}(\mathrm{T}<=\mathrm{t})$ one-tail & 0.2653306 & \\
\hline t Critical one-tail & 1.859548038 & & t Critical one-tail & 1.859548 & \\
\hline $\mathrm{P}(\mathrm{T}<=\mathrm{t})$ two-tail & 0.419234203 & & $\mathrm{P}(\mathrm{T}<=\mathrm{t})$ two-tail & 0.5306612 & \\
\hline t Critical two-tail & 2.306004135 & & t Critical two-tail & 2.3060041 & \\
\hline
\end{tabular}


California Test 225 vs Hard Paper Method

t-Test: Two-Sample Assuming Equal Variances

\begin{tabular}{lrr}
\hline & Variable 1 & Variable 2 \\
\hline Mean & 2.63329849 & 2.6298592 \\
Variance & $9.135 \mathrm{E}-06$ & $4.428 \mathrm{E}-05$ \\
Observations & 5 & 5 \\
Pooled Variance & $2.6708 \mathrm{E}-05$ & \\
Hypothesized Mean & 0 & \\
Difference & 8 & \\
df & 1.0522579 & \\
$\mathrm{t}$ Stat & 0.16171191 & \\
$\mathrm{P}(\mathrm{T}<=\mathrm{t})$ one-tail & 1.85954804 & \\
$\mathrm{t}$ Critical one-tail & 0.32342382 & \\
$\mathrm{P}(\mathrm{T}<=\mathrm{t})$ two-tail & 2.30600414 & \\
$\mathrm{t}$ Critical two-tail & &
\end{tabular}

Decision
\% Absorption

t-Test: Two-Sample Assuming Equal Variances

\begin{tabular}{lrr}
\hline & Variable 1 & Variable 2 \\
\hline Mean & 1.097871659 & 1.09972382 \\
Variance & 0.000986974 & 0.00839953 \\
Observations & 5 & 5 \\
Pooled Variance & 0.00469325 & \\
Hypothesized Mean & 0 & \\
Difference & 8 \\
df & -0.04274752 \\
t Stat & 0.483475237 \\
P(T<=t) one-tail & 1.859548038 \\
t Critical one-tail & 0.966950475 \\
P(T<=t) two-tail & 2.306004135 & \\
t Critical two-tail & cannot reject Ho \\
\hline Decision &
\end{tabular}

Wisconsin Method vs Arizona DOT Method

$\mathrm{G}_{\mathrm{sb}}$

t-Test: Two-Sample Assuming Equal Variances

\begin{tabular}{lrr}
\hline & Variable 1 & Variable 2 \\
\hline Mean & 2.66234141 & 2.6177444 \\
Variance & $5.3837 \mathrm{E}-05$ & $5.827 \mathrm{E}-06$ \\
Observations & 5 & 5 \\
Pooled Variance & $2.9832 \mathrm{E}-05$ & \\
Hypothesized Mean & & \\
Difference & 0 & \\
df & 8 &
\end{tabular}

\% Absorption

t-Test: Two-Sample Assuming Equal Variances

\begin{tabular}{lrr}
\hline & Variable 1 & Variable 2 \\
\hline Mean & 0.618462913 & 1.27157054 \\
Variance & 0.005839103 & 0.00533844 \\
Observations & 5 & 5 \\
Pooled Variance & 0.005588772 & \\
Hypothesized Mean & & \\
Difference & 0 & \\
df & 8 &
\end{tabular}

$\mathrm{G}_{\mathrm{sa}}$

t-Test: Two-Sample Assuming Equal Variances

\begin{tabular}{lrr}
\hline & Variable 1 & Variable 2 \\
\hline Mean & 2.711692 & 2.7081703 \\
Variance & $2.569 \mathrm{E}-06$ & $5.164 \mathrm{E}-06$ \\
Observations & 5 & 5 \\
$\begin{array}{l}\text { Pooled Variance } \\
\text { Hypothesized Mean }\end{array}$ & $3.866 \mathrm{E}-06$ & \\
Difference & 0 & \\
df & 8 &
\end{tabular}

2.8318488

$\mathrm{P}(\mathrm{T}<=\mathrm{t})$ one-tail $\quad 0.0110436$

$\mathrm{t}$ Critical one-tail $\quad 1.859548$

$\mathrm{P}(\mathrm{T}<=\mathrm{t})$ two-tail $\quad 0.0220873$

$\mathrm{t}$ Critical two-tail $\quad 2.3060041$

Decision reject $\mathrm{Ho}$

$\mathrm{G}_{\mathrm{sa}}$

t-Test: Two-Sample Assuming Equal Variances

\begin{tabular}{lrr}
\hline & Variable 1 & Variable 2 \\
\hline Mean & 2.7068979 & 2.7078816 \\
Variance & $7.623 \mathrm{E}-06$ & $1.15 \mathrm{E}-05$ \\
Observations & 5 & 5 \\
Pooled Variance & $9.563 \mathrm{E}-06$ & \\
Hypothesized Mean & & \\
Difference & 0 & \\
df & 8 &
\end{tabular}




\begin{tabular}{|c|c|c|c|c|c|}
\hline t Stat & 12.9102754 & t Stat & -13.8132723 & t Stat & 0.5029794 \\
\hline $\mathrm{P}(\mathrm{T}<=\mathrm{t})$ one-tail & $6.1288 \mathrm{E}-07$ & $\mathrm{P}(\mathrm{T}<=\mathrm{t})$ one-tail & $3.644 \mathrm{E}-07$ & $\mathrm{P}(\mathrm{T}<=\mathrm{t})$ one-tail & 0.3142657 \\
\hline t Critical one-tail & 1.85954804 & t Critical one-tail & 1.859548038 & t Critical one-tail & 1.859548 \\
\hline $\mathrm{P}(\mathrm{T}<=\mathrm{t})$ two-tail & $1.2258 \mathrm{E}-06$ & $\mathrm{P}(\mathrm{T}<=\mathrm{t})$ two-tail & $7.288 \mathrm{E}-07$ & $\mathrm{P}(\mathrm{T}<=\mathrm{t})$ two-tail & 0.6285314 \\
\hline t Critical two-tail & 2.30600414 & t Critical two-tail & 2.306004135 & t Critical two-tail & 2.3060041 \\
\hline
\end{tabular}

Corelok Method vs Arizona DOT Method

G

t-Test: Two-Sample Assuming Equal Variances

\begin{tabular}{lrr}
\hline & Variable 1 & Variable 2 \\
\hline Mean & 2.6438 & 2.6177444 \\
Variance & $1.57 \mathrm{E}-05$ & $5.827 \mathrm{E}-06$ \\
Observations & 5 & 5 \\
Pooled Variance & $1.0763 \mathrm{E}-05$ & \\
Hypothesized Mean & & \\
Difference & 0 & \\
df & 8 & \\
$\mathrm{t}$ Stat & 12.5573186 & \\
$\mathrm{P}(\mathrm{T}<=\mathrm{t})$ one-tail & $7.5789 \mathrm{E}-07$ & \\
$\mathrm{t}$ Critical one-tail & 1.85954804 & \\
$\mathrm{P}(\mathrm{T}<=\mathrm{t})$ two-tail & $1.5158 \mathrm{E}-06$ & \\
$\mathrm{t}$ Critical two-tail & 2.30600414 & \\
\hline Decision & reject Ho
\end{tabular}

lowa Method vs Arizona DOT Method

$\mathrm{G}_{\mathrm{sb}}$

\begin{tabular}{lcc}
\multicolumn{3}{l}{ t-Test: Two-Sample Assuming Equal Variances } \\
\hline Variable 1 & Variable 2 \\
\hline Mean & 2.63185445 & 2.6177444
\end{tabular}

$\%$ Absorption

t-Test: Two-Sample Assuming Equal Variances

\begin{tabular}{lrr}
\hline & Variable 1 & Variable 2 \\
\hline Mean & 0.837 & 1.27157054 \\
Variance & 0.0037905 & 0.00533844 \\
Observations & 5 & 5 \\
Pooled Variance & 0.00456447 & \\
Hypothesized Mean & 0 & \\
Difference & 8 & \\
df & & \\
t Stat & -10.1703314 & \\
$\mathrm{P}(\mathrm{T}<=\mathrm{t})$ one-tail & $3.74076 \mathrm{E}-06$ & \\
$\mathrm{t}$ Critical one-tail & 1.859548038 & \\
$\mathrm{P}(\mathrm{T}<=\mathrm{t})$ two-tail & $7.48153 \mathrm{E}-06$ & \\
$\mathrm{t}$ Critical two-tail & 2.306004135 & \\
\hline Decision & reject Ho &
\end{tabular}

\% Absorption

t-Test: Two-Sample Assuming Equal Variances

\begin{tabular}{lcc}
\hline & Variable 1 & Variable 2 \\
\hline Mean & 1.033838337 & 1.27157054
\end{tabular}

\section{$\mathrm{G}_{\mathrm{sa}}$}

t-Test: Two-Sample Assuming Equal Variances

\begin{tabular}{lrr}
\hline & Variable 1 & Variable 2 \\
\hline Mean & 2.7034 & 2.7078816 \\
Variance & $2.3 \mathrm{E}-06$ & $1.15 \mathrm{E}-05$ \\
Observations & 5 & 5 \\
Pooled Variance & $6.902 \mathrm{E}-06$ & \\
Hypothesized Mean & 0 & \\
Difference & 8 & \\
df & - & \\
t Stat & 2.6973247 & \\
$\mathrm{P}(\mathrm{T}<=\mathrm{t})$ one-tail & 0.0135932 & \\
$\mathrm{t}$ Critical one-tail & 1.859548 & \\
$\mathrm{P}(\mathrm{T}<=\mathrm{t})$ two-tail & 0.0271864 & \\
$\mathrm{t}$ Critical two-tail & 2.3060041 & \\
\hline Decision & reject Ho
\end{tabular}

$\mathrm{G}_{\text {sa }}$

t-Test: Two-Sample Assuming Equal Variances

\begin{tabular}{lcc}
\hline & Variable 1 & Variable 2 \\
\hline Mean & 2.7054668 & 2.7078816
\end{tabular}




\begin{tabular}{|c|c|c|c|c|c|c|c|c|}
\hline Variance & $1.1718 \mathrm{E}-05$ & 5.827E-06 & Variance & 0.000415527 & 0.00533844 & Variance & $9.217 \mathrm{E}-06$ & $1.15 \mathrm{E}-05$ \\
\hline Observations & 5 & 5 & Observations & 5 & 5 & Observations & 5 & 5 \\
\hline $\begin{array}{l}\text { Pooled Variance } \\
\text { Hypothesized Mean }\end{array}$ & $8.7725 \mathrm{E}-06$ & & $\begin{array}{l}\text { Pooled Variance } \\
\text { Hypothesized Mean }\end{array}$ & 0.002876983 & & $\begin{array}{l}\text { Pooled Variance } \\
\text { Hypothesized Mean }\end{array}$ & $1.036 \mathrm{E}-05$ & \\
\hline Difference & 0 & & Difference & 0 & & Difference & 0 & \\
\hline df & 8 & & df & 8 & & df & 8 & \\
\hline t Stat & 7.53249923 & & t Stat & -7.00792332 & & t Stat & 1.1862394 & \\
\hline $\mathrm{P}(\mathrm{T}<=\mathrm{t})$ one-tail & $3.3591 \mathrm{E}-05$ & & $\mathrm{P}(\mathrm{T}<=\mathrm{t})$ one-tail & $5.58758 \mathrm{E}-05$ & & $\mathrm{P}(\mathrm{T}<=\mathrm{t})$ one-tail & 0.1347801 & \\
\hline t Critical one-tail & 1.85954804 & & t Critical one-tail & 1.859548038 & & t Critical one-tail & 1.859548 & \\
\hline $\mathrm{P}(\mathrm{T}<=\mathrm{t})$ two-tail & $6.7182 \mathrm{E}-05$ & & $\mathrm{P}(\mathrm{T}<=\mathrm{t})$ two-tail & 0.000111752 & & $\mathrm{P}(\mathrm{T}<=\mathrm{t})$ two-tail & 0.2695602 & \\
\hline t Critical two-tail & 2.30600414 & & $\mathrm{t}$ Critical two-tail & 2.306004135 & & t Critical two-tail & 2.3060041 & \\
\hline Decision & reject Ho & & Decision & reject Ho & & Decision & cannot rejec & Ho \\
\hline \multicolumn{9}{|c|}{ Texas Method vs Arizona DOT Method } \\
\hline $\mathrm{G}_{\mathrm{sb}}$ & & & \% Absorption & & & $\mathrm{G}_{\mathrm{sa}}$ & & \\
\hline \multicolumn{3}{|c|}{ t-Test: Two-Sample Assuming Equal Variances } & \multicolumn{3}{|c|}{ t-Test: Two-Sample Assuming Equal Variances } & \multicolumn{3}{|c|}{ t-Test: Two-Sample Assuming Equal Variances } \\
\hline & Variable 1 & Variable 2 & & Variable 1 & Variable 2 & & Variable 1 & Variable 2 \\
\hline Mean & 2.64190449 & 2.6177444 & Mean & 1.051588395 & 1.27157054 & Mean & 2.7094727 & 2.7078816 \\
\hline Variance & $1.158 \mathrm{E}-05$ & 5.827E-06 & Variance & 0.007577714 & 0.00533844 & Variance & $1.459 \mathrm{E}-05$ & $1.15 \mathrm{E}-05$ \\
\hline Observations & 5 & 5 & Observations & 5 & 5 & Observations & 5 & 5 \\
\hline $\begin{array}{l}\text { Pooled Variance } \\
\text { Hypothesized Mean }\end{array}$ & $8.7036 \mathrm{E}-06$ & & $\begin{array}{l}\text { Pooled Variance } \\
\text { Hypothesized Mean }\end{array}$ & 0.006458077 & & $\begin{array}{l}\text { Pooled Variance } \\
\text { Hypothesized Mean }\end{array}$ & $1.304 \mathrm{E}-05$ & \\
\hline Difference & 0 & & Difference & 0 & & Difference & 0 & \\
\hline df & 8 & & df & 8 & & df & 8 & \\
\hline t Stat & 12.9485392 & & $\mathrm{t}$ Stat & -4.32818514 & & $\mathrm{t}$ Stat & 0.6965255 & \\
\hline $\mathrm{P}(\mathrm{T}<=\mathrm{t})$ one-tail & 5.9913E-07 & & $\mathrm{P}(\mathrm{T}<=\mathrm{t})$ one-tail & 0.001259066 & & $\mathrm{P}(\mathrm{T}<=\mathrm{t})$ one-tail & 0.2529151 & \\
\hline t Critical one-tail & 1.85954804 & & t Critical one-tail & 1.859548038 & & t Critical one-tail & 1.859548 & \\
\hline $\mathrm{P}(\mathrm{T}<=\mathrm{t})$ two-tail & $1.1983 \mathrm{E}-06$ & & $\mathrm{P}(\mathrm{T}<=\mathrm{t})$ two-tail & 0.002518131 & & $\mathrm{P}(\mathrm{T}<=\mathrm{t})$ two-tail & 0.5058301 & \\
\hline t Critical two-tail & 2.30600414 & & $\mathrm{t}$ Critical two-tail & 2.306004135 & & t Critical two-tail & 2.3060041 & \\
\hline Decision & reject Ho & & Decision & reject Ho & & Decision & cannot rejec & Ho \\
\hline
\end{tabular}


California Test 225 vs Arizona DOT Method

$\mathrm{G}_{\mathrm{sb}}$

t-Test: Two-Sample Assuming Equal Variances

\begin{tabular}{lrr}
\hline & Variable 1 & Variable 2 \\
\hline Mean & 2.63329849 & 2.6177444 \\
Variance & $9.135 \mathrm{E}-06$ & $5.827 \mathrm{E}-06$ \\
Observations & 5 & 5 \\
Pooled Variance & $7.4809 \mathrm{E}-06$ & \\
Hypothesized Mean & 0 & \\
Difference & 8 & \\
df & 8.99162727 & \\
$\mathrm{t}$ Stat & $9.3292 \mathrm{E}-06$ & \\
$\mathrm{P}(\mathrm{T}<=\mathrm{t})$ one-tail & 1.85954804 & \\
$\mathrm{t}$ Critical one-tail & $1.8658 \mathrm{E}-05$ & \\
$\mathrm{P}(\mathrm{T}<=\mathrm{t})$ two-tail & 2.30600414 & \\
$\mathrm{t}$ Critical two-tail & reject Ho &
\end{tabular}

Corelok Method vs Wisconsin Method

t-Test: Two-Sample Assuming Equal Variances

\begin{tabular}{lrr}
\hline & Variable 1 & Variable 2 \\
\hline Mean & 2.6438 & 2.6623414 \\
Variance & $1.57 \mathrm{E}-05$ & $5.384 \mathrm{E}-05$ \\
Observations & 5 & 5 \\
Pooled Variance & $3.4769 \mathrm{E}-05$ & \\
Hypothesized Mean & & \\
Difference & 0 & \\
df & 8 & \\
t Stat & -4.9718696 & \\
$\mathrm{P}(\mathrm{T}<=\mathrm{t})$ one-tail & 0.00054527 &
\end{tabular}

$\%$ Absorption

t-Test: Two-Sample Assuming Equal Variances

\begin{tabular}{lrr}
\hline & Variable 1 & Variable 2 \\
\hline Mean & 1.097871659 & 1.27157054 \\
Variance & 0.000986974 & 0.00533844 \\
Observations & 5 & 5 \\
Pooled Variance & 0.003162707 & \\
Hypothesized Mean & 0 & \\
Difference & 8 & \\
df & & \\
t Stat & -4.88357137 & \\
P(T<=t) one-tail & 0.000609417 & \\
$t$ Critical one-tail & 1.859548038 & \\
P(T<=t) two-tail & 0.001218834 & \\
$t$ Critical two-tail & 2.306004135 & \\
\hline Decision & reject Ho &
\end{tabular}

\% Absorption

t-Test: Two-Sample Assuming Equal Variances

\begin{tabular}{lrr}
\hline & Variable 1 & Variable 2 \\
\hline Mean & 0.5996 & 0.61846291 \\
Variance & 0.0012428 & 0.0058391 \\
Observations & 5 & 5 \\
Pooled Variance & 0.003540952 & \\
Hypothesized Mean & & \\
Difference & 0 & \\
df & 8 & \\
t Stat & -0.5012089 & \\
$P(T<=t)$ one-tail & 0.314861143 &
\end{tabular}

$\mathrm{G}_{\mathrm{sa}}$

t-Test: Two-Sample Assuming Equal Variances

\begin{tabular}{lrr}
\hline & Variable 1 & Variable 2 \\
\hline Mean & 2.711692 & 2.7078816 \\
Variance & $2.569 \mathrm{E}-06$ & $1.15 \mathrm{E}-05$ \\
Observations & 5 & 5
\end{tabular}

Pooled Variance 7.036E-06

Hypothesized Mean

Difference 0

df

t Stat

$\mathrm{P}(\mathrm{T}<=\mathrm{t})$ one-tail $\quad 0.026392$

$\mathrm{t}$ Critical one-tail $\quad 1.859548$

$\mathrm{P}(\mathrm{T}<=\mathrm{t})$ two-tail $\quad 0.052784$

$\mathrm{t}$ Critical two-tail $\quad 2.3060041$

Decision cannot reject Ho

$\mathrm{G}_{\mathrm{sa}}$

t-Test: Two-Sample Assuming Equal Variances

\begin{tabular}{lrr}
\hline & Variable 1 & Variable 2 \\
\hline Mean & 2.7068979 & 2.7034 \\
Variance & $7.623 \mathrm{E}-06$ & $2.3 \mathrm{E}-06$ \\
Observations & 5 & 5 \\
Pooled Variance & $4.961 \mathrm{E}-06$ & \\
Hypothesized Mean & & \\
Difference & 0 & \\
df & 8 & \\
t Stat & 2.4829599 & \\
$P(T<=t)$ one-tail & 0.0189681 &
\end{tabular}




\begin{tabular}{|c|c|c|c|c|c|}
\hline t Critical one-tail & 1.85954804 & t Critical one-tail & 1.859548038 & t Critical one-tail & 1.859548 \\
\hline $\mathrm{P}(\mathrm{T}<=\mathrm{t})$ two-tail & 0.00109054 & $\mathrm{P}(\mathrm{T}<=\mathrm{t})$ two-tail & 0.629722285 & $\mathrm{P}(\mathrm{T}<=\mathrm{t})$ two-tail & 0.0379362 \\
\hline t Critical two-tail & 2.30600414 & t Critical two-tail & 2.306004135 & t Critical two-tail & 2.3060041 \\
\hline Decision & reject Ho & Decision & cannot reject $\mathrm{Ho}$ & Decision & reject Ho \\
\hline
\end{tabular}

lowa Method vs Wisconsin Method

t-Test: Two-Sample Assuming Equal Variances

\begin{tabular}{lrr}
\hline & Variable 1 & Variable 2 \\
\hline Mean & 2.63185445 & 2.6623414 \\
Variance & $1.1718 \mathrm{E}-05$ & $5.384 \mathrm{E}-05$ \\
Observations & 5 & 5 \\
Pooled Variance & $3.2778 \mathrm{E}-05$ & \\
Hypothesized Mean & & \\
Difference & 0 & \\
df & 8 & \\
t Stat & -8.4196834 & \\
$\mathrm{P}(\mathrm{T}<=\mathrm{t})$ one-tail & $1.5083 \mathrm{E}-05$ & \\
$\mathrm{t}$ Critical one-tail & 1.85954804 & \\
$\mathrm{P}(\mathrm{T}<=\mathrm{t})$ two-tail & $3.0167 \mathrm{E}-05$ & \\
$\mathrm{t}$ Critical two-tail & 2.30600414 & \\
\hline
\end{tabular}

Decision reject Ho

Texas Method vs Wisconsin Method

t-Test: Two-Sample Assuming Equal Variances

\begin{tabular}{lrr}
\hline & Variable 1 & Variable 2 \\
\hline Mean & 2.64190449 & 2.6623414 \\
Variance & $1.158 \mathrm{E}-05$ & $5.384 \mathrm{E}-05$ \\
Observations & 5 & 5 \\
Pooled Variance & $3.2709 \mathrm{E}-05$ &
\end{tabular}

\% Absorption

t-Test: Two-Sample Assuming Equal Variances

\begin{tabular}{lrr} 
& Variable 1 & Variable 2 \\
\hline Mean & 1.033838337 & 0.61846291 \\
Variance & 0.000415527 & 0.0058391 \\
Observations & 5 & 5 \\
Pooled Variance & 0.003127315 & \\
Hypothesized Mean & 0 & \\
Difference & 8 & \\
df & 11.74424189 & \\
t Stat & $1.26298 \mathrm{E}-06$ & \\
$\mathrm{P}(\mathrm{T}<=\mathrm{t})$ one-tail & 1.859548038 & \\
t Critical one-tail & $2.52596 \mathrm{E}-06$ & \\
$\mathrm{P}(\mathrm{T}<=\mathrm{t})$ two-tail & 2.306004135 & \\
$\mathrm{t}$ Critical two-tail & reject Ho & \\
\hline Decision & &
\end{tabular}

\% Absorption

t-Test: Two-Sample Assuming Equal Variances

\begin{tabular}{lrr}
\hline & Variable 1 & Variable 2 \\
\hline Mean & 1.051588395 & 0.61846291 \\
Variance & 0.007577714 & 0.0058391 \\
Observations & 5 & 5 \\
Pooled Variance & 0.006708409 &
\end{tabular}

$\mathrm{G}_{\mathrm{sa}}$

t-Test: Two-Sample Assuming Equal Variances

\begin{tabular}{lrr}
\hline & Variable 1 & Variable 2 \\
\hline Mean & 2.7054668 & 2.7068979 \\
Variance & $9.217 \mathrm{E}-06$ & $7.623 \mathrm{E}-06$ \\
Observations & 5 & 5 \\
Pooled Variance & $8.42 \mathrm{E}-06$ & \\
Hypothesized Mean & & \\
Difference & 0 \\
$\mathrm{df}$ & - \\
$\mathrm{t}$ Stat & 0.7797877 \\
$\mathrm{P}(\mathrm{T}<=\mathrm{t})$ one-tail & 0.2289813 & \\
$\mathrm{t}$ Critical one-tail & 1.859548 & \\
$\mathrm{P}(\mathrm{T}<=\mathrm{t})$ two-tail & 0.4579627 & \\
$\mathrm{t}$ Critical two-tail & 2.3060041 & \\
\hline Decision & cannot reject Ho
\end{tabular}

$\mathrm{G}_{\mathrm{sa}}$

t-Test: Two-Sample Assuming Equal Variances

\begin{tabular}{lrr}
\hline & Variable 1 & Variable 2 \\
\hline Mean & 2.7094727 & 2.7068979 \\
Variance & $1.459 \mathrm{E}-05$ & $7.623 \mathrm{E}-06$ \\
Observations & 5 & 5 \\
Pooled Variance & $1.11 \mathrm{E}-05$ &
\end{tabular}




\begin{tabular}{|c|c|c|c|c|c|}
\hline \multirow{2}{*}{$\begin{array}{l}\text { Hypothesized Mean } \\
\text { Difference }\end{array}$} & \multirow[b]{2}{*}{0} & \multicolumn{2}{|l|}{ Hypothesized Mean } & \multicolumn{2}{|c|}{ Hypothesized Mean } \\
\hline & & Difference & 0 & Difference & 0 \\
\hline df & 8 & $\mathrm{df}$ & 8 & df & 8 \\
\hline t Stat & -5.6500726 & t Stat & 8.361303514 & t Stat & 1.2216728 \\
\hline $\mathrm{P}(\mathrm{T}<=\mathrm{t})$ one-tail & 0.00024069 & $\mathrm{P}(\mathrm{T}<=\mathrm{t})$ one-tail & $1.58654 \mathrm{E}-05$ & $\mathrm{P}(\mathrm{T}<=\mathrm{t})$ one-tail & 0.1283033 \\
\hline t Critical one-tail & 1.85954804 & t Critical one-tail & 1.859548038 & t Critical one-tail & 1.859548 \\
\hline $\mathrm{P}(\mathrm{T}<=\mathrm{t})$ two-tail & 0.00048138 & $\mathrm{P}(\mathrm{T}<=\mathrm{t})$ two-tail & $3.17308 \mathrm{E}-05$ & $\mathrm{P}(\mathrm{T}<=\mathrm{t})$ two-tail & 0.2566065 \\
\hline
\end{tabular}

California Test 225 vs Wisconsin Method

t-Test: Two-Sample Assuming Equal Variances

\begin{tabular}{lrr}
\hline & Variable 1 & Variable 2 \\
\hline Mean & 2.63329849 & 2.6623414 \\
Variance & $9.135 \mathrm{E}-06$ & $5.384 \mathrm{E}-05$ \\
Observations & 5 & 5 \\
Pooled Variance & $3.1486 \mathrm{E}-05$ & \\
Hypothesized Mean & 0 & \\
Difference & 8 \\
df & -8.1837312 \\
t Stat & $1.8535 \mathrm{E}-05$ & \\
P(T<=t) one-tail & 1.85954804 & \\
t Critical one-tail & $3.707 \mathrm{E}-05$ & \\
P(T<=t) two-tail & 2.30600414 & \\
t Critical two-tail & reject Ho
\end{tabular}

lowa Method vs CoreLok Method

$\mathrm{G}_{\mathrm{sb}}$

t-Test: Two-Sample Assuming Equal Variances

Variable 1 Variable 2
\% Absorption

t-Test: Two-Sample Assuming Equal Variances

\begin{tabular}{lrr}
\hline & \multicolumn{1}{c}{ Variable 1 } & \multicolumn{1}{c}{ Variable 2 } \\
\hline Mean & 1.097871659 & 0.61846291 \\
Variance & 0.000986974 & 0.0058391 \\
Observations & 5 & 5 \\
Pooled Variance & 0.003413039 & \\
Hypothesized Mean & & \\
Difference & 0 & \\
df & 8 &
\end{tabular}

12.97493982

$\mathrm{P}(\mathrm{T}<=\mathrm{t})$ one-tail 5.89837E-07

$\mathrm{t}$ Critical one-tail $\quad 1.859548038$

$\mathrm{P}(\mathrm{T}<=\mathrm{t})$ two-tail 1.17967E-06

$\mathrm{t}$ Critical two-tail $\quad 2.306004135$

Decision

reject Ho

$\%$ Absorption

t-Test: Two-Sample Assuming Equal Variances

Variable 1

Variable 2
$\mathrm{G}_{\mathrm{sa}}$

t-Test: Two-Sample Assuming Equal Variances

\begin{tabular}{lrr}
\hline & Variable 1 & Variable 2 \\
\hline Mean & 2.711692 & 2.7068979 \\
Variance & $2.569 \mathrm{E}-06$ & $7.623 \mathrm{E}-06$ \\
Observations & 5 & 5 \\
Pooled Variance & $5.096 \mathrm{E}-06$ & \\
Hypothesized Mean & 0 & \\
Difference & 8 & \\
df & 3.3578256 \\
t Stat & 0.0049819 & \\
$\mathrm{P}(\mathrm{T}<=\mathrm{t})$ one-tail & 1.859548 & \\
$\mathrm{t}$ Critical one-tail & 0.0099639 & \\
$\mathrm{P}(\mathrm{T}<=\mathrm{t})$ two-tail & 2.3060041 & \\
$\mathrm{t}$ Critical two-tail & reject Ho
\end{tabular}

$\mathrm{G}_{\mathrm{sa}}$

t-Test: Two-Sample Assuming Equal Variances Variable $1 \quad$ Variable 2 


\begin{tabular}{|c|c|c|c|c|c|c|c|c|}
\hline Mean & 2.63185445 & 2.6438 & Mean & 1.033838337 & 0.837 & Mean & 2.7054668 & 2.7034 \\
\hline Variance & $1.1718 \mathrm{E}-05$ & $1.57 \mathrm{E}-05$ & Variance & 0.000415527 & 0.0037905 & Variance & 9.217E-06 & $2.3 \mathrm{E}-06$ \\
\hline Observations & 5 & 5 & Observations & 5 & 5 & Observations & 5 & 5 \\
\hline Pooled Variance & $1.3709 \mathrm{E}-05$ & & Pooled Variance & 0.002103013 & & Pooled Variance & $5.759 \mathrm{E}-06$ & \\
\hline Difference & 0 & & Difference & 0 & & Difference & 0 & \\
\hline df & 8 & & $\mathrm{df}$ & 8 & & $\mathrm{df}$ & 8 & \\
\hline t Stat & -5.1012007 & & t Stat & 6.786700436 & & t Stat & 1.3618048 & \\
\hline $\mathrm{P}(\mathrm{T}<=\mathrm{t})$ one-tail & 0.00046424 & & $\mathrm{P}(\mathrm{T}<=\mathrm{t})$ one-tail & $6.98534 \mathrm{E}-05$ & & $\mathrm{P}(\mathrm{T}<=\mathrm{t})$ one-tail & 0.1051838 & \\
\hline t Critical one-tail & 1.85954804 & & t Critical one-tail & 1.859548038 & & t Critical one-tail & 1.859548 & \\
\hline $\mathrm{P}(\mathrm{T}<=\mathrm{t})$ two-tail & 0.00092847 & & $\mathrm{P}(\mathrm{T}<=\mathrm{t})$ two-tail & 0.000139707 & & $\mathrm{P}(\mathrm{T}<=\mathrm{t})$ two-tail & 0.2103676 & \\
\hline t Critical two-tail & 2.30600414 & & t Critical two-tail & 2.306004135 & & t Critical two-tail & 2.3060041 & \\
\hline Decision & reject Ho & & Decision & reject Ho & & Decision & cannot reje & \\
\hline
\end{tabular}

Texas Method vs CoreLok Method

\section{$\mathrm{G}_{\mathrm{sb}}$}

t-Test: Two-Sample Assuming Equal Variances

\begin{tabular}{lrr}
\hline & Variable 1 & Variable 2 \\
\hline Mean & 2.64190449 & 2.6438 \\
Variance & $1.158 \mathrm{E}-05$ & $1.57 \mathrm{E}-05$ \\
Observations & 5 & 5 \\
Pooled Variance & $1.364 \mathrm{E}-05$ & \\
Hypothesized Mean & & \\
Difference & 0 \\
$\mathrm{df}$ & 8 \\
$\mathrm{t}$ Stat & -0.8114961 \\
$\mathrm{P}(\mathrm{T}<=\mathrm{t})$ one-tail & 0.22027749 \\
$\mathrm{t}$ Critical one-tail & 1.85954804 \\
$\mathrm{P}(\mathrm{T}<=\mathrm{t})$ two-tail & 0.44055497 \\
$\mathrm{t}$ Critical two-tail & 2.30600414 \\
\hline Decision & cannot reject Ho
\end{tabular}

\% Absorption

t-Test: Two-Sample Assuming Equal Variances

\begin{tabular}{lrr} 
& Variable 1 & Variable 2 \\
\hline Mean & 1.051588395 & 0.837 \\
Variance & 0.007577714 & 0.0037905 \\
Observations & 5 & 5 \\
Pooled Variance & 0.005684107 & \\
Hypothesized Mean & 0 & \\
Difference & 8 & \\
df & & \\
t Stat & & \\
P(T<=t) one-tail & 0.001000599 & \\
t Critical one-tail & 1.859548038 & \\
P(T<=t) two-tail & 0.002001198 & \\
t Critical two-tail & 2.306004135 & \\
\hline Decision & reject Ho &
\end{tabular}

$\mathrm{G}_{\mathrm{sa}}$

t-Test: Two-Sample Assuming Equal Variances

\begin{tabular}{lrr}
\hline & Variable 1 & Variable 2 \\
\hline Mean & 2.7094727 & 2.7034 \\
Variance & $1.459 \mathrm{E}-05$ & $2.3 \mathrm{E}-06$ \\
Observations & 5 & 5 \\
Pooled Variance & $8.443 \mathrm{E}-06$ & \\
Hypothesized Mean & 0 & \\
Difference & 8 \\
$\mathrm{df}$ & 3.3043817 \\
$\mathrm{t}$ Stat & 0.0053941 & \\
$\mathrm{P}(\mathrm{T}<=\mathrm{t})$ one-tail & 1.859548 \\
$\mathrm{t}$ Critical one-tail & 0.0107882 & \\
$\mathrm{P}(\mathrm{T}<=\mathrm{t})$ two-tail & 2.3060041 & \\
$\mathrm{t}$ Critical two-tail & reject Ho
\end{tabular}


California Test 225 vs CoreLok Method

$\mathrm{G}_{\mathrm{sb}}$

t-Test: Two-Sample Assuming Equal Variances

\begin{tabular}{lrr} 
& Variable 1 & Variable 2 \\
\hline Mean & 2.63329849 & 2.6438 \\
Variance & $9.135 \mathrm{E}-06$ & $1.57 \mathrm{E}-05$ \\
Observations & 5 & 5 \\
Pooled Variance & $1.2418 \mathrm{E}-05$ & \\
Hypothesized Mean & 0 & \\
Difference & 8 & \\
df & -4.711991 & \\
$\mathrm{t}$ Stat & 0.00075888 & \\
$\mathrm{P}(\mathrm{T}<=\mathrm{t})$ one-tail & 1.85954804 & \\
$\mathrm{t}$ Critical one-tail & 0.00151777 & \\
$\mathrm{P}(\mathrm{T}<=\mathrm{t})$ two-tail & 2.30600414 & \\
$\mathrm{t}$ Critical two-tail & reject Ho
\end{tabular}

Texas Method vs lowa Method

$\mathrm{G}_{\mathrm{sb}}$

t-Test: Two-Sample Assuming Equal Variances

\begin{tabular}{lrr}
\hline & Variable 1 & Variable 2 \\
\hline Mean & 2.64190449 & 2.6318545 \\
Variance & $1.158 \mathrm{E}-05$ & $1.172 \mathrm{E}-05$ \\
Observations & 5 & 5 \\
Pooled Variance & $1.1649 \mathrm{E}-05$ & \\
Hypothesized Mean & 0 & \\
Difference & 8 & \\
df & 4.65574868 & \\
t Stat & 0.00081622 & \\
P(T<=t) one-tail & 1.85954804 & \\
t Critical one-tail &
\end{tabular}

$\%$ Absorption

t-Test: Two-Sample Assuming Equal Variances

\begin{tabular}{lrr}
\hline & Variable 1 & Variable 2 \\
\hline Mean & 1.097871659 & 0.837 \\
Variance & 0.000986974 & 0.0037905 \\
Observations & 5 & 5 \\
Pooled Variance & 0.002388737 & \\
Hypothesized Mean & 0 & \\
Difference & 8 & \\
df & & \\
t Stat & 8.439422641 & \\
P(T<=t) one-tail & $1.48288 \mathrm{E}-05$ & \\
$\mathrm{t}$ Critical one-tail & 1.859548038 & \\
$\mathrm{P}(\mathrm{T}<=\mathrm{t})$ two-tail & $2.96577 \mathrm{E}-05$ & \\
$\mathrm{t}$ Critical two-tail & 2.306004135 & \\
\hline Decision & reject Ho &
\end{tabular}

\% Absorption

t-Test: Two-Sample Assuming Equal Variances

\begin{tabular}{lrr}
\hline & \multicolumn{1}{c}{ Variable 1 } & Variable 2 \\
\hline Mean & 1.051588395 & 1.03383834 \\
Variance & 0.007577714 & 0.00041553 \\
Observations & 5 & 5 \\
$\begin{array}{l}\text { Pooled Variance } \\
\text { Hypothesized Mean } \\
\text { Difference }\end{array}$ & 0.00399662 & \\
df & 0 &
\end{tabular}

$\mathrm{P}(\mathrm{T}<=\mathrm{t})$ one-tail

$\mathrm{t}$ Critical one-tail
$\mathrm{G}_{\mathrm{sa}}$

t-Test: Two-Sample Assuming Equal Variances

\begin{tabular}{lrr} 
& Variable 1 & Variable 2 \\
\hline Mean & 2.711692 & 2.7034 \\
Variance & $2.569 \mathrm{E}-06$ & $2.3 \mathrm{E}-06$ \\
Observations & 5 & 5
\end{tabular}

Pooled Variance 2.435E-06

Hypothesized Mean

Difference 0

t Stat

$\mathrm{P}(\mathrm{T}<=\mathrm{t})$ one-tail $\quad 1.531 \mathrm{E}-05$

$\mathrm{t}$ Critical one-tail $\quad 1.859548$

$\mathrm{P}(\mathrm{T}<=\mathrm{t})$ two-tail $\quad 3.062 \mathrm{E}-05$

$\mathrm{t}$ Critical two-tail $\quad 2.3060041$

Decision reject $\mathrm{Ho}$

$\mathrm{G}_{\mathrm{sa}}$

t-Test: Two-Sample Assuming Equal Variances

\begin{tabular}{lrr}
\hline & Variable 1 & Variable 2 \\
\hline Mean & 2.7094727 & 2.7054668 \\
Variance & $1.459 \mathrm{E}-05$ & $9.217 \mathrm{E}-06$ \\
Observations & 5 & 5
\end{tabular}

Pooled Variance 1.19E-05

Hypothesized Mean
Difference

df 8

t Stat 1.8359359

$\mathrm{P}(\mathrm{T}<=\mathrm{t})$ one-tail $\quad 0.0518447$

$\mathrm{t}$ Critical one-tail $\quad 1.859548$ 


\begin{tabular}{|c|c|c|c|c|c|}
\hline $\mathrm{P}(\mathrm{T}<=\mathrm{t})$ two-tail & 0.00163244 & $\mathrm{P}(\mathrm{T}<=\mathrm{t})$ two-tail & 0.668849132 & $\mathrm{P}(\mathrm{T}<=\mathrm{t})$ two-tail & 0.1036895 \\
\hline t Critical two-tail & 2.30600414 & t Critical two-tail & 2.306004135 & t Critical two-tail & 2.3060041 \\
\hline Decision & reject Ho & Decision & cannot reject Ho & Decision & cannot reject Ho \\
\hline
\end{tabular}

California Test 225 vs lowa Method

$\mathrm{G}_{\mathrm{sb}}$

t-Test: Two-Sample Assuming Equal Variances

\begin{tabular}{lrr}
\hline & Variable 1 & Variable 2 \\
\hline Mean & 2.63329849 & 2.6318545 \\
Variance & $9.135 \mathrm{E}-06$ & $1.172 \mathrm{E}-05$ \\
Observations & 5 & 5 \\
Pooled Variance & $1.0427 \mathrm{E}-05$ & \\
Hypothesized Mean & 0 & \\
Difference & 8 & \\
$\mathrm{df}$ & 0.70709623 & \\
$\mathrm{t}$ Stat & 0.24979105 & \\
$\mathrm{P}(\mathrm{T}<=\mathrm{t})$ one-tail & 1.85954804 & \\
$\mathrm{t}$ Critical one-tail & 0.4995821 & \\
$\mathrm{P}(\mathrm{T}<=\mathrm{t})$ two-tail & 2.30600414 & \\
$\mathrm{t}$ Critical two-tail & &
\end{tabular}

Decision cannot reject $\mathrm{Ho}$

California test 225 vs Texas Method

t-Test: Two-Sample Assuming Equal Variances

\begin{tabular}{lrr}
\hline & Variable 1 & Variable 2 \\
\hline Mean & 2.63329849 & 2.6419045 \\
Variance & $9.135 \mathrm{E}-06$ & $1.158 \mathrm{E}-05$ \\
Observations & 5 & 5 \\
$\begin{array}{l}\text { Pooled Variance } \\
\text { Hypothesized Mean } \\
\text { Difference }\end{array}$ & $1.0358 \mathrm{E}-05$ & \\
& & \\
& 0 &
\end{tabular}

$\%$ Absorption

t-Test: Two-Sample Assuming Equal Variances

\begin{tabular}{lrr}
\hline & Variable 1 & Variable 2 \\
\hline Mean & 1.097871659 & 1.03383834 \\
Variance & 0.000986974 & 0.00041553 \\
Observations & 5 & 5 \\
Pooled Variance & 0.00070125 & \\
Hypothesized Mean & 0 & \\
Difference & 8 & \\
df & 3.823309878 & \\
t Stat & 0.002532917 & \\
$\mathrm{P}(\mathrm{T}<=\mathrm{t})$ one-tail & 1.859548038 & \\
t Critical one-tail & 0.005065835 & \\
$\mathrm{P}(\mathrm{T}<=\mathrm{t})$ two-tail & 2.306004135 & \\
$\mathrm{t}$ Critical two-tail & reject Ho & \\
\hline Decision &
\end{tabular}

\% Absorption

t-Test: Two-Sample Assuming Equal Variances

\begin{tabular}{lrr}
\hline & Variable 1 & Variable 2 \\
\hline Mean & 1.097871659 & 1.05158839 \\
Variance & 0.000986974 & 0.00757771 \\
Observations & 5 & 5 \\
$\begin{array}{l}\text { Pooled Variance } \\
\text { Hypothesized Mean } \\
\text { Difference }\end{array}$ & 0.004282344 & \\
& 0 &
\end{tabular}

$\mathrm{G}_{\mathrm{sa}}$

t-Test: Two-Sample Assuming Equal Variances

\begin{tabular}{lrr}
\hline & Variable 1 & Variable 2 \\
\hline Mean & 2.711692 & 2.7054668 \\
Variance & $2.569 \mathrm{E}-06$ & $9.217 \mathrm{E}-06$ \\
Observations & 5 & 5 \\
Pooled Variance & $5.893 \mathrm{E}-06$ & \\
Hypothesized Mean & 0 & \\
Difference & 8 \\
$\mathrm{df}$ & 4.0546 \\
$\mathrm{t}$ Stat & 0.0018304 \\
$\mathrm{P}(\mathrm{T}<=\mathrm{t})$ one-tail & 1.859548 \\
$\mathrm{t}$ Critical one-tail & 0.0036608 \\
$\mathrm{P}(\mathrm{T}<=\mathrm{t})$ two-tail & 2.3060041 & \\
$\mathrm{t}$ Critical two-tail & reject Ho
\end{tabular}

$\mathrm{G}_{\mathrm{sa}}$

t-Test: Two-Sample Assuming Equal Variances

\begin{tabular}{lrr}
\hline & Variable 1 & Variable 2 \\
\hline Mean & 2.711692 & 2.7094727 \\
Variance & $2.569 \mathrm{E}-06$ & $1.459 \mathrm{E}-05$ \\
Observations & 5 & 5 \\
$\begin{array}{l}\text { Pooled Variance } \\
\text { Hypothesized Mean } \\
\text { Difference }\end{array}$ & $8.578 \mathrm{E}-06$ & \\
& 0 &
\end{tabular}




\section{Slag fine aggregates}

Provisional Cone test vs Standard AASHTO T84

$\mathrm{G}_{\mathrm{sb}}$

t-Test: Two-Sample Assuming Equal Variances

\begin{tabular}{lrr} 
& Variable 1 & Variable 2 \\
\hline Mean & 2.585670471 & 2.581675593 \\
Variance & $2.51641 \mathrm{E}-05$ & $2.42629 \mathrm{E}-05$ \\
Observations & 5 & 5 \\
Pooled Variance & $2.47135 \mathrm{E}-05$ & \\
Hypothesized Mean & & \\
Difference & 0 \\
df & 8 \\
t Stat & 1.270593803 \\
$\mathrm{P}(\mathrm{T}<=\mathrm{t})$ one-tail & 0.119787821 \\
$\mathrm{t}$ Critical one-tail & 1.859548038 \\
$\mathrm{P}(\mathrm{T}<=\mathrm{t})$ two-tail & 0.239575643 \\
$\mathrm{t}$ Critical two-tail & 2.306004135 \\
\hline
\end{tabular}

Decision
\% Absorption

t-Test: Two-Sample Assuming Equal Variances

\begin{tabular}{lrr}
\hline & Variable 1 & Variable 2 \\
\hline Mean & 2.173440261 & 2.249000618 \\
Variance & 0.010261538 & 0.007159319 \\
Observations & 5 & 5 \\
Pooled Variance & 0.008710429 & \\
Hypothesized & & \\
Mean Difference & 0 & \\
df & 8 &
\end{tabular}

t Stat

\section{$\mathrm{P}(\mathrm{T}<=\mathrm{t})$ one-tail}

$-1.280101012$

t Critical one-tail

0.118189286

$\mathrm{P}(\mathrm{T}<=\mathrm{t})$ two-tai

1.859548038

$\mathrm{t}$ Critical two-tail

0.236378572

Decision
2.306004135

cannot reject $\mathrm{Ho}$
$\mathrm{G}_{\mathrm{sa}}$

t-Test: Two-Sample Assuming Equal Variances

\begin{tabular}{lrr}
\hline & Variable 1 & \multicolumn{1}{c}{ Variable 2 } \\
\hline Mean & 2.739632195 & 2.740813798 \\
Variance & $2.94752 \mathrm{E}-05$ & $3.39365 \mathrm{E}-05$ \\
Observations & 5 & 5 \\
Pooled Variance & $3.17058 \mathrm{E}-05$ & \\
Hypothesized Mean & & \\
Difference & 0 & \\
df & 8 &
\end{tabular}

t Stat

$-0.331796486$

$\mathrm{P}(\mathrm{T}<=\mathrm{t})$ one-tail $\quad 0.374284181$

$\mathrm{t}$ Critical one-tail $\quad 1.859548038$

$\mathrm{P}(\mathrm{T}<=\mathrm{t})$ two-tail $\quad 0.748568363$

$\mathrm{t}$ Critical two-tail $\quad 2.306004135$

Decision

Provisional Surface test vs Standard AASHTO T84 
$\mathrm{G}_{\mathrm{sb}}$

t-Test: Two-Sample Assuming Equal Variances

\begin{tabular}{|c|c|c|}
\hline & Variable 1 & Variable 2 \\
\hline Mean & 2.578801985 & 2.581675593 \\
\hline Variance & $2.43636 \mathrm{E}-05$ & $2.42629 \mathrm{E}-05$ \\
\hline Observations & 5 & 5 \\
\hline Pooled Variance & $2.43132 \mathrm{E}-05$ & \\
\hline $\begin{array}{l}\text { Hypothesized Me } \\
\text { Difference }\end{array}$ & 0 & \\
\hline df & $\begin{array}{l}8 \\
-\end{array}$ & \\
\hline t Stat & 0.921459592 & \\
\hline $\mathrm{P}(\mathrm{T}<=\mathrm{t})$ one-tail & 0.191878531 & \\
\hline t Critical one-tail & 1.859548038 & \\
\hline $\mathrm{P}(\mathrm{T}<=\mathrm{t})$ two-tail & 0.383757062 & \\
\hline $\mathrm{t}$ Critical two-tail & 2.306004135 & \\
\hline
\end{tabular}

Decision

cannot reject $\mathrm{Ho}$

Hard Paper Method vs Standard AASHTO T84

t-Test: Two-Sample Assuming Equal Variances

\begin{tabular}{lrr}
\hline & \multicolumn{1}{c}{ Variable 1 } & Variable 2 \\
\hline Mean & 2.581988139 & 2.581675593 \\
Variance & $2.29539 \mathrm{E}-05$ & $2.42629 \mathrm{E}-05$ \\
Observations & 5 & 5 \\
Pooled Variance & $2.36084 \mathrm{E}-05$ & \\
Hypothesized Mean & & \\
Difference & 0 & \\
df & 8 & \\
t Stat & 0.101707049 \\
$\mathrm{P}(\mathrm{T}<=\mathrm{t})$ one-tail & 0.460746104 & \\
t Critical one-tail & 1.859548038 &
\end{tabular}

$\%$ Absorption

t-Test: Two-Sample Assuming Equal Variances

\begin{tabular}{lrr} 
& Variable 1 & Variable 2 \\
\hline Mean & 2.309363834 & 2.249000618 \\
Variance & 0.004412621 & 0.007159319 \\
Observations & 5 & 5
\end{tabular}

Observations 5

Pooled Variance

0.00578597

Hypothesized

Mean Difference

0

\begin{tabular}{ll}
$\mathrm{t}$ Stat & 1.254741537 \\
$\mathrm{P}(\mathrm{T}<=\mathrm{t})$ one-tail & 0.122493692 \\
$\mathrm{t}$ Critical one-tail & 1.859548038 \\
$\mathrm{P}(\mathrm{T}<=\mathrm{t})$ two-tail & 0.244987384 \\
$\mathrm{t}$ Critical two-tail & 2.306004135 \\
\hline Decision & cannot reject Ho
\end{tabular}

Decision

cannot reject Ho

\% Absorption

t-Test: Two-Sample Assuming Equal Variances

\begin{tabular}{lrr}
\hline & Variable 1 & Variable 2 \\
\hline Mean & 2.230624229 & 2.249000618 \\
Variance & 0.004422822 & 0.007159319 \\
Observations & 5 & 5 \\
Pooled Variance & 0.005791071 & \\
Hypothesized & 0 & \\
Mean Difference & 8 & \\
df & & \\
t Stat & -0.381813035 & \\
P(T<=t) one-tail & 0.356271033 & \\
t Critical one-tail & 1.859548038 &
\end{tabular}

$\mathrm{G}_{\mathrm{sa}}$

t-Test: Two-Sample Assuming Equal Variances

\begin{tabular}{lrr}
\hline & Variable 1 & Variable 2 \\
\hline Mean & 2.742098407 & 2.740813798 \\
Variance & $6.36252 \mathrm{E}-06$ & $3.39365 \mathrm{E}-05$ \\
Observations & 5 & 5 \\
Pooled Variance & $2.01495 \mathrm{E}-05$ & \\
Hypothesized Mean & 0 \\
Difference & 8 \\
df & \\
t Stat & 0.452489885 \\
$\mathrm{P}(\mathrm{T}<=\mathrm{t})$ one-tail & 0.331467162 \\
$\mathrm{t}$ Critical one-tail & 1.859548038 \\
$\mathrm{P}(\mathrm{T}<=\mathrm{t})$ two-tail & 0.662934324 \\
$\mathrm{t}$ Critical two-tail & 2.306004135 \\
\hline Decision & cannot reject Ho
\end{tabular}

$\mathrm{G}_{\mathrm{sa}}$

t-Test: Two-Sample Assuming Equal Variances

\begin{tabular}{lrr}
\hline & Variable 1 & Variable 2 \\
\hline Mean & 2.739779533 & 2.740813798 \\
Variance & $1.03461 \mathrm{E}-05$ & $3.39365 \mathrm{E}-05$ \\
Observations & 5 & 5 \\
Pooled Variance & $2.21413 \mathrm{E}-05$ & \\
Hypothesized Mean & & \\
Difference & 0 & \\
df & 8 & \\
t Stat & -0.347536516 & \\
P(T<=t) one-tail & 0.368577402 & \\
t Critical one-tail & 1.859548038 &
\end{tabular}




\begin{tabular}{|c|c|c|}
\hline $\begin{array}{l}\mathrm{P}(\mathrm{T}<=\mathrm{t}) \text { two-tail } \\
\text { t Critical two-tail }\end{array}$ & \multicolumn{2}{|l|}{0.921492209} \\
\hline Decision & \multicolumn{2}{|c|}{ cannot reject Ho } \\
\hline \multirow{2}{*}{\multicolumn{3}{|c|}{$\begin{array}{l}\text { Arizona DOT Method vs Standard AASHTO T84 } \\
\qquad \mathrm{G}_{\mathrm{sb}} \\
\text { t-Test: Two-Sample Assuming Equal Variances }\end{array}$}} \\
\hline & & \\
\hline & Variable 1 & Variable 2 \\
\hline Mean & 2.589072123 & 2.581675593 \\
\hline Variance & 2.03027E-05 & $2.42629 \mathrm{E}-05$ \\
\hline Observations & 5 & 5 \\
\hline Pooled Variance & $2.22828 \mathrm{E}-05$ & \\
\hline $\begin{array}{l}\text { Hypothesized Me } \\
\text { Difference }\end{array}$ & 0 & \\
\hline df & 8 & \\
\hline t Stat & 2.47749795 & \\
\hline $\mathrm{P}(\mathrm{T}<=\mathrm{t})$ one-tail & 0.019130296 & \\
\hline t Critical one-tail & 1.859548038 & \\
\hline $\mathrm{P}(\mathrm{T}<=\mathrm{t})$ two-tail & 0.038260593 & \\
\hline t Critical two-tail & 2.306004135 & \\
\hline
\end{tabular}

\begin{tabular}{ll}
$\mathrm{P}(\mathrm{T}<=\mathrm{t})$ two-tail & 0.712542066 \\
$\mathrm{t}$ Critical two-tail & 2.306004135 \\
\hline Decision & cannot reject Ho
\end{tabular}

\begin{tabular}{ll}
$\mathrm{P}(\mathrm{T}<=\mathrm{t})$ two-tail & 0.737154803 \\
$\mathrm{t}$ Critical two-tail & 2.306004135 \\
\hline Decision & cannot reject Ho
\end{tabular}

\% Absorption

t-Test: Two-Sample Assuming Equal Variances

\begin{tabular}{lrr}
\hline & Variable 1 & Variable 2 \\
\hline Mean & 2.136857453 & 2.249000618 \\
Variance & 0.009385425 & 0.007159319 \\
Observations & 5 & 5 \\
Pooled Variance & 0.008272372 & \\
Hypothesized & 0 \\
Mean Difference & 8 \\
df & \\
t Stat & -1.949520397 \\
$\mathrm{P}(\mathrm{T}<=\mathrm{t})$ one-tail & 0.043528334 \\
$\mathrm{t}$ Critical one-tail & 1.859548038 \\
$\mathrm{P}(\mathrm{T}<=\mathrm{t})$ two-tail & 0.087056669 \\
$\mathrm{t}$ Critical two-tail & 2.306004135 \\
\hline Decision & cannot reject Ho
\end{tabular}

Wisconsin Method vs Standard AASHTO T84

$\mathrm{G}_{\mathrm{sb}}$

t-Test: Two-Sample Assuming Equal Variances

\begin{tabular}{lrr}
\hline & Variable 1 & Variable 2 \\
\hline Mean & 2.648191358 & 2.581675593 \\
Variance & $3.10593 \mathrm{E}-05$ & $2.42629 \mathrm{E}-05$ \\
Observations & 5 & 5 \\
Pooled Variance & $2.76611 \mathrm{E}-05$ &
\end{tabular}

\% Absorption

t-Test: Two-Sample Assuming Equal Variances

\begin{tabular}{lrr}
\hline & Variable 1 & Variable 2 \\
\hline Mean & 1.292328953 & 2.249000618 \\
Variance & 0.010630769 & 0.007159319 \\
Observations & 5 & 5 \\
Pooled Variance & 0.008895044 &
\end{tabular}

$\mathrm{G}_{\mathrm{sa}}$

t-Test: Two-Sample Assuming Equal Variances

\begin{tabular}{lrr}
\hline & Variable 1 & Variable 2 \\
\hline Mean & 2.7406968 & 2.740813798 \\
Variance & $1.04231 \mathrm{E}-05$ & $3.39365 \mathrm{E}-05$ \\
Observations & 5 & 5 \\
Pooled Variance & $2.21798 \mathrm{E}-05$ & \\
Hypothesized Mean & 0 \\
Difference & 8 \\
df & -0.039279915 \\
t Stat & 0.484814888 \\
$\mathrm{P}(\mathrm{T}<=\mathrm{t})$ one-tail & 1.859548038 \\
$\mathrm{t}$ Critical one-tail & 0.969629776 \\
$\mathrm{P}(\mathrm{T}<=\mathrm{t})$ two-tail & 2.306004135 \\
$\mathrm{t}$ Critical two-tail & cannot reject Ho
\end{tabular}

$\mathrm{G}_{\mathrm{sa}}$

t-Test: Two-Sample Assuming Equal Variances

\begin{tabular}{lrr}
\hline & \multicolumn{1}{c}{ Variable 1 } & \multicolumn{1}{c}{ Variable 2 } \\
\hline Mean & 2.742027431 & 2.740813798 \\
Variance & $1.57444 \mathrm{E}-05$ & $3.39365 \mathrm{E}-05$ \\
Observations & 5 & 5 \\
Pooled Variance & $2.48405 \mathrm{E}-05$ &
\end{tabular}




\begin{tabular}{lr}
$\begin{array}{lr}\text { Hypothesized Mean } \\
\text { Difference }\end{array}$ & 0 \\
df & 8 \\
t Stat & 19.99678276 \\
$\mathrm{P}(\mathrm{T}<=\mathrm{t})$ one-tail & $2.03954 \mathrm{E}-08$ \\
$\mathrm{t}$ Critical one-tail & 1.859548038 \\
$\mathrm{P}(\mathrm{T}<=\mathrm{t})$ two-tail & $4.07907 \mathrm{E}-08$ \\
$\mathrm{t}$ Critical two-tail & 2.306004135 \\
\hline Decision & reject Ho
\end{tabular}

Hypothesized

Mean Difference

df

t Stat

$\mathrm{P}(\mathrm{T}<=\mathrm{t})$ one-tail 1.14557E-07

$\mathrm{t}$ Critical one-tail 1.859548038

$\mathrm{P}(\mathrm{T}<=\mathrm{t})$ two-tail $\quad 2.29114 \mathrm{E}-07$

$\mathrm{t}$ Critical two-tail $\quad 2.306004135$

Decision reject Ho

Hypothesized Mean

Difference

0

df

t Stat $\quad 0.38501499$

$\mathrm{P}(\mathrm{T}<=\mathrm{t})$ one-tail $\quad 0.355130254$

$\mathrm{t}$ Critical one-tail $\quad 1.859548038$

$\mathrm{P}(\mathrm{T}<=\mathrm{t})$ two-tail $\quad 0.710260507$

$\mathrm{t}$ Critical two-tail $\quad 2.306004135$

Decision cannot reject Ho

$\mathrm{G}_{\mathrm{sa}}$

t-Test: Two-Sample Assuming Equal Variances

t-Test: Two-Sample Assuming Equal Variances

\begin{tabular}{lrr}
\hline & Variable 1 & \multicolumn{2}{c}{ Variable 2 } \\
\hline Mean & 2.5908 & 2.581675593 \\
Variance & $2.12 \mathrm{E}-05$ & $2.42629 \mathrm{E}-05$ \\
Observations & 5 & 5
\end{tabular}

(n)

t-Test: Two-Sample Assuming Equal Variances

\begin{tabular}{lrc} 
& Variable 1 & Variable 2 \\
\hline Mean & 2.118 & 2.249000618
\end{tabular}

$\begin{array}{lll}\text { Variance } & 0.0038265 & 0.007159319\end{array}$

Observations

5

Pooled Variance

2.27314E-05

Hypothesized Mean

Difference 0

df

t Stat

3.025946754

$\mathrm{P}(\mathrm{T}<=\mathrm{t})$ one-tail

0.008205148

t Critical one-tail

1.859548038

$\mathrm{P}(\mathrm{T}<=\mathrm{t})$ two-tail

0.016410296

t Critical two-tail

2.306004135

Decision

reject Ho

0.00549291

Hypothesized

Mean Difference

df

0

t Stat

8

$\mathrm{P}(\mathrm{T}<=\mathrm{t})$ one-tail

t Critical one-tail $\quad 1.859548038$

$\mathrm{P}(\mathrm{T}<=\mathrm{t})$ two-tail $\quad 0.023386569$

$\mathrm{t}$ Critical two-tail $\quad 2.306004135$

Decision reject $\mathrm{Ho}$

\% Absorption

t-Test: Two-Sample Assuming Equal Variances

\begin{tabular}{lrr} 
& Variable 1 & Variable 2 \\
\hline Mean & 2.7412 & 2.740813798 \\
Variance & 0.0000022 & $3.39365 \mathrm{E}-05$ \\
Observations & 5 & 5 \\
Pooled Variance & $1.80683 \mathrm{E}-05$ & \\
Hypothesized Mean & & \\
Difference & 0 & \\
df & 8 \\
$\mathrm{t}$ Stat & 0.143656934 \\
$\mathrm{P}(\mathrm{T}<=\mathrm{t})$ one-tail & 0.444662051 & \\
$\mathrm{t}$ Critical one-tail & 1.859548038 \\
$\mathrm{P}(\mathrm{T}<=\mathrm{t})$ two-tail & 0.889324102 & \\
$\mathrm{t}$ Critical two-tail & 2.306004135 & \\
\hline Decision & cannot reject Ho
\end{tabular}

lowa Method vs Standard AASHTO T 84

$\mathrm{G}_{\mathrm{sb}}$

t-Test: Two-Sample Assuming Equal Variances
$\mathrm{G}_{\mathrm{sa}}$

t-Test: Two-Sample Assuming Equal Variances 


\begin{tabular}{|c|c|c|}
\hline & Variable 1 & Variable 2 \\
\hline Mean & 2.613826503 & 2.581675593 \\
\hline Variance & $1.45227 \mathrm{E}-05$ & $2.42629 \mathrm{E}-05$ \\
\hline Observations & 5 & 5 \\
\hline Pooled Variance & $1.93928 \mathrm{E}-05$ & \\
\hline $\begin{array}{l}\text { Hypothesized Mea } \\
\text { Difference }\end{array}$ & 0 & \\
\hline df & 8 & \\
\hline t Stat & 11.54364946 & \\
\hline $\mathrm{P}(\mathrm{T}<=\mathrm{t})$ one-tail & $1.43961 \mathrm{E}-06$ & \\
\hline t Critical one-tail & 1.859548038 & \\
\hline $\mathrm{P}(\mathrm{T}<=\mathrm{t})$ two-tail & 2.87923E-06 & \\
\hline t Critical two-tail & 2.306004135 & \\
\hline Decision & reject Ho & \\
\hline \multirow{2}{*}{\multicolumn{3}{|c|}{$\begin{array}{l}\text { Texas Method vs Standard AASHTO T84 } \\
\qquad G_{\text {sb }} \\
\text { t-Test: Two-Sample Assuming Equal Variances }\end{array}$}} \\
\hline & & \\
\hline & Variable 1 & Variable 2 \\
\hline Mean & 2.64230855 & 2.581675593 \\
\hline Variance & $1.53927 \mathrm{E}-05$ & $2.42629 \mathrm{E}-05$ \\
\hline Observations & 5 & 5 \\
\hline Pooled Variance & $1.98278 \mathrm{E}-05$ & \\
\hline $\begin{array}{l}\text { Hypothesized Mea } \\
\text { Difference }\end{array}$ & 0 & \\
\hline$d f$ & 8 & \\
\hline t Stat & 21.52987918 & \\
\hline $\mathrm{P}(\mathrm{T}<=\mathrm{t})$ one-tail & $1.14051 \mathrm{E}-08$ & \\
\hline t Critical one-tail & 1.859548038 & \\
\hline $\mathrm{P}(\mathrm{T}<=\mathrm{t})$ two-tail & $2.28102 \mathrm{E}-08$ & \\
\hline t Critical two-tail & 2.306004135 & \\
\hline
\end{tabular}

\begin{tabular}{lrr}
\hline & Variable 1 & Variable 2 \\
\hline Mean & 1.772296724 & 2.249000618 \\
Variance & 0.005646844 & 0.007159319 \\
Observations & 5 & 5 \\
Pooled Variance & 0.006403081 & \\
Hypothesized & 0 & \\
Mean Difference & 8 & \\
df & & \\
t Stat & -9.41942061 & \\
P(T<=t) one-tail & $6.621 \mathrm{E}-06$ & \\
t Critical one-tail & 1.859548038 & \\
P(T<=t) two-tail & $1.3242 \mathrm{E}-05$ & \\
t Critical two-tail & 2.306004135 & \\
\hline
\end{tabular}

\begin{tabular}{lrr}
\hline & Variable 1 & Variable 2 \\
\hline Mean & 2.740790258 & 2.740813798 \\
Variance & $7.05002 \mathrm{E}-06$ & $3.39365 \mathrm{E}-05$ \\
Observations & 5 & 5 \\
Pooled Variance & $2.04933 \mathrm{E}-05$ \\
Hypothesized Mean & \\
Difference & 0 \\
df & 8 \\
t Stat & -0.008221768 \\
$\mathrm{P}(\mathrm{T}<=\mathrm{t})$ one-tail & 0.496820691 \\
$\mathrm{t}$ Critical one-tail & 1.859548038 \\
$\mathrm{P}(\mathrm{T}<=\mathrm{t})$ two-tail & 0.993641381 \\
$\mathrm{t}$ Critical two-tail & 2.306004135 \\
\hline Decision & cannot reject Ho
\end{tabular}

\% Absorption

t-Test: Two-Sample Assuming Equal Variances

\begin{tabular}{lrr}
\hline & Variable 1 & \multicolumn{1}{c}{ Variable 2 } \\
\hline Mean & 1.485641157 & 2.249000618 \\
Variance & 0.008513207 & 0.007159319 \\
Observations & 5 & 5 \\
Pooled Variance & 0.007836263 & \\
Hypothesized & 0 & \\
Mean Difference & 8 & \\
df & & \\
t Stat & -13.63466852 & \\
$\mathrm{P}(\mathrm{T}<=\mathrm{t})$ one-tail & $4.02842 \mathrm{E}-07$ & \\
$\mathrm{t}$ Critical one-tail & 1.859548038 & \\
$\mathrm{P}(\mathrm{T}<=\mathrm{t})$ two-tail & $8.05685 \mathrm{E}-07$ & \\
$\mathrm{t}$ Critical two-tail & 2.306004135 & \\
\hline
\end{tabular}

$\mathrm{G}_{\mathrm{sa}}$

t-Test: Two-Sample Assuming Equal Variances

\begin{tabular}{lrr}
\hline & Variable 1 & \multicolumn{1}{c}{ Variable 2 } \\
\hline Mean & 2.740429693 & 2.740813798 \\
Variance & $9.39621 \mathrm{E}-06$ & $3.39365 \mathrm{E}-05$ \\
Observations & 5 & 5 \\
Pooled Variance & $2.16664 \mathrm{E}-05$ & \\
Hypothesized Mean & 0 & \\
Difference & 8 & \\
df & & \\
$t$ Stat & -0.130474979 & \\
$\mathrm{P}(\mathrm{T}<=\mathrm{t})$ one-tail & 0.449705938 & \\
$\mathrm{t}$ Critical one-tail & 1.859548038 & \\
$\mathrm{P}(\mathrm{T}<=\mathrm{t})$ two-tail & 0.899411876 & \\
$\mathrm{t}$ Critical two-tail & 2.306004135 & \\
\hline
\end{tabular}


California Test 225 vs Standard AASHTO T84

$\mathrm{G}_{\mathrm{sb}}$

t-Test: Two-Sample Assuming Equal Variances

\begin{tabular}{lrr}
\hline & Variable 1 & Variable 2 \\
\hline Mean & 2.595249707 & 2.581675593 \\
Variance & $4.34241 \mathrm{E}-05$ & $2.42629 \mathrm{E}-05$ \\
Observations & 5 & 5 \\
Pooled Variance & $3.38435 \mathrm{E}-05$ & \\
Hypothesized Mean & 0 & \\
Difference & 8 \\
df & & \\
t Stat & 3.689298808 & \\
$\mathrm{P}(\mathrm{T}<=\mathrm{t})$ one-tail & 0.003068198 & \\
t Critical one-tail & 1.859548038 & \\
$\mathrm{P}(\mathrm{T}<=\mathrm{t})$ two-tail & 0.006136395 & \\
$\mathrm{t}$ Critical two-tail & 2.306004135 & \\
\hline Decision & reject Ho
\end{tabular}

Provisional Surface test vs Provisional Cone test

t-Test: Two-Sample Assuming Equal Variances

\begin{tabular}{|c|c|c|}
\hline & Variable 1 & Variable 2 \\
\hline Mean & 2.578801985 & 2.585670471 \\
\hline Variance & $2.43636 \mathrm{E}-05$ & $2.51641 \mathrm{E}-05$ \\
\hline Observations & 5 & \\
\hline Pooled Variance & $2.47638 \mathrm{E}-05$ & \\
\hline $\begin{array}{l}\text { Hypothesized Mean } \\
\text { Difference }\end{array}$ & 0 & \\
\hline df & 8 & \\
\hline
\end{tabular}

\% Absorption

t-Test: Two-Sample Assuming Equal Variances

\begin{tabular}{lrr} 
& Variable 1 & Variable 2 \\
\hline Mean & 2.047250137 & 2.249000618 \\
Variance & 0.00932495 & 0.007159319 \\
Observations & 5 & 5 \\
Pooled Variance & 0.008242135 & \\
Hypothesized & 0 & \\
Mean Difference & 8 & \\
df & & \\
t Stat & -3.51370039 & \\
$\mathrm{P}(\mathrm{T}<=\mathrm{t})$ one-tail & 0.003959285 & \\
$\mathrm{t}$ Critical one-tail & 1.859548038 & \\
$\mathrm{P}(\mathrm{T}<=\mathrm{t})$ two-tail & 0.007918569 & \\
$\mathrm{t}$ Critical two-tail & 2.306004135 & \\
\hline Decision & reject Ho
\end{tabular}

\% Absorption

t-Test: Two-Sample Assuming Equal Variances

\begin{tabular}{lrr} 
& Variable 1 & Variable 2 \\
\hline Mean & 1.192836724 & 0.989966962 \\
Variance & 0.001274891 & 0.001478676 \\
Observations & 5 & 5 \\
Pooled Variance & 0.001376784 & \\
Hypothesized & & \\
Mean Difference & 0 & \\
df & 8 &
\end{tabular}

$\mathrm{G}_{\mathrm{sa}}$

t-Test: Two-Sample Assuming Equal Variances

\begin{tabular}{lrr}
\hline & Variable 1 & Variable 2 \\
\hline Mean & 2.740861917 & 2.740813798 \\
Variance & $3.24632 \mathrm{E}-06$ & $3.39365 \mathrm{E}-05$ \\
Observations & 5 & 5 \\
Pooled Variance & $1.85914 \mathrm{E}-05$ & \\
Hypothesized Mean & 0 & \\
Difference & 8 \\
df & 0.017645531 \\
t Stat & 0.493176889 \\
$\mathrm{P}(\mathrm{T}<=\mathrm{t})$ one-tail & 1.859548038 \\
$\mathrm{t}$ Critical one-tail & 0.986353777 \\
$\mathrm{P}(\mathrm{T}<=\mathrm{t})$ two-tail & 2.306004135 \\
$\mathrm{t}$ Critical two-tail & cannot reject Ho
\end{tabular}

$\mathrm{G}_{\mathrm{sa}}$

t-Test: Two-Sample Assuming Equal Variances

\begin{tabular}{lrr}
\hline & Variable 1 & Variable 2 \\
\hline Mean & 2.742098407 & 2.739632195 \\
Variance & $6.36252 \mathrm{E}-06$ & $2.94752 \mathrm{E}-05$ \\
Observations & 5 & 5 \\
Pooled Variance & $1.79188 \mathrm{E}-05$ & \\
Hypothesized Mean & & \\
Difference & 0 & \\
df & 8 &
\end{tabular}




\begin{tabular}{|c|c|c|c|c|c|}
\hline t Stat & 2.182339022 & t Stat & 8.644790524 & t Stat & 0.921181871 \\
\hline $\mathrm{P}(\mathrm{T}<=\mathrm{t})$ one-tail & 0.030320473 & $\mathrm{P}(\mathrm{T}<=\mathrm{t})$ one-tail & $1.24456 \mathrm{E}-05$ & $\mathrm{P}(\mathrm{T}<=\mathrm{t})$ one-tail & 0.191946749 \\
\hline t Critical one-tail & 1.859548038 & t Critical one-tail & 1.859548038 & t Critical one-tail & 1.859548038 \\
\hline $\mathrm{P}(\mathrm{T}<=\mathrm{t})$ two-tail & 0.060640945 & $\mathrm{P}(\mathrm{T}<=\mathrm{t})$ two-tail & $2.48912 \mathrm{E}-05$ & $\mathrm{P}(\mathrm{T}<=\mathrm{t})$ two-tail & 0.383893498 \\
\hline t Critical two-tail & 2.306004135 & t Critical two-tail & 2.306004135 & t Critical two-tail & 2.306004135 \\
\hline
\end{tabular}

Hard Paper Method vs Provisional cone test

\section{$\mathrm{G}_{\mathrm{sb}}$}

t-Test: Two-Sample Assuming Equal Variances

\begin{tabular}{lrr}
\hline & Variable 1 & Variable 2 \\
\hline Mean & 2.581988139 & 2.585670471 \\
Variance & $2.29539 E-05$ & $2.51641 \mathrm{E}-05$ \\
Observations & 5 & 5 \\
Pooled Variance & $2.4059 \mathrm{E}-05$ & \\
Hypothesized Mean & & \\
Difference & 0 \\
df & 8 \\
t Stat & - \\
P(T<=t) one-tail & 0.134636488 \\
t Critical one-tail & 1.859548038 \\
P(T<=t) two-tail & 0.269272976 \\
t Critical two-tail & 2.306004135 \\
\hline Decision & \multicolumn{2}{|c}{} \\
\hline
\end{tabular}

Decision

cannot reject $\mathrm{Ho}$

Arizona DOT vs Provisional Cone test

$\mathrm{G}_{\mathrm{sb}}$

t-Test: Two-Sample Assuming Equal Variances

\begin{tabular}{lcc}
\hline & Variable 1 & Variable 2 \\
\hline Mean & 2.589072123 & 2.585670471
\end{tabular}

\% Absorption

t-Test: Two-Sample Assuming Equal Variances

\begin{tabular}{lrr}
\hline & Variable 1 & Variable 2 \\
\hline Mean & 2.230624229 & 2.173440261 \\
Variance & 0.004422822 & 0.010261538 \\
Observations & 5 & 5 \\
Pooled Variance & 0.00734218 & \\
Hypothesized & 0 & \\
Mean Difference & 8 & \\
df & & \\
t Stat & 1.05519268 \\
$\mathrm{P}(\mathrm{T}<=\mathrm{t})$ one-tail & 0.161079573 & \\
$\mathrm{t}$ Critical one-tail & 1.859548038 \\
$\mathrm{P}(\mathrm{T}<=\mathrm{t})$ two-tail & 0.322159146 \\
$\mathrm{t}$ Critical two-tail & 2.306004135 \\
\hline
\end{tabular}

Decision

cannot reject $\mathrm{Ho}$
$\mathrm{G}_{\mathrm{sa}}$

t-Test: Two-Sample Assuming Equal Variances

\begin{tabular}{lrr}
\hline & Variable 1 & Variable 2 \\
\hline Mean & 2.739779533 & 2.739632195 \\
Variance & $1.03461 \mathrm{E}-05$ & $2.94752 \mathrm{E}-05$ \\
Observations & 5 & 5 \\
Pooled Variance & $1.99106 \mathrm{E}-05$ & \\
Hypothesized Mean & & \\
Difference & 0 & \\
df & 8 &
\end{tabular}

t Stat 0.052208334

$\mathrm{P}(\mathrm{T}<=\mathrm{t})$ one-tail $\quad 0.479821401$

$\mathrm{t}$ Critical one-tail $\quad 1.859548038$

$\mathrm{P}(\mathrm{T}<=\mathrm{t})$ two-tail $\quad 0.959642801$

$\mathrm{t}$ Critical two-tail $\quad 2.306004135$

Decision cannot reject Ho
\% Absorption

t-Test: Two-Sample Assuming Equal Variances

\begin{tabular}{ccc} 
& Variable 1 & Variable 2 \\
\hline Mean & 2.136857453 & 2.173440261
\end{tabular}

$\mathrm{G}_{\mathrm{sa}}$

t-Test: Two-Sample Assuming Equal Variances

\begin{tabular}{lcc}
\hline & Variable 1 & Variable 2 \\
\hline Mean & 2.7406968 & 2.739632195
\end{tabular}




\begin{tabular}{|c|c|c|c|c|c|c|c|c|}
\hline Variance & 2.03027E-05 & $2.51641 \mathrm{E}-05$ & Variance & 0.009385425 & 0.010261538 & Variance & $1.04231 \mathrm{E}-05$ & $2.94752 \mathrm{E}-05$ \\
\hline Observations & 5 & 5 & Observations & 5 & 5 & Observations & 5 & 5 \\
\hline Pooled Variance & 2.27334E-05 & & Pooled Variance & 0.009823481 & & Pooled Variance & $1.99491 \mathrm{E}-05$ & \\
\hline Hypothesized Mean & & & Hypothesized & & & Hypothesized Mean & & \\
\hline Difference & 0 & & Mean Difference & 0 & & Difference & 0 & \\
\hline$d f$ & 8 & & $d f$ & 8 & & $d f$ & 8 & \\
\hline t Stat & 1.128048582 & & t Stat & -0.583598718 & & t Stat & 0.376873961 & \\
\hline $\mathrm{P}(\mathrm{T}<=\mathrm{t})$ one-tail & 0.145995619 & & $\mathrm{P}(\mathrm{T}<=\mathrm{t})$ one-tail & 0.287785139 & & $\mathrm{P}(\mathrm{T}<=\mathrm{t})$ one-tail & 0.358033727 & \\
\hline t Critical one-tail & 1.859548038 & & t Critical one-tail & 1.859548038 & & t Critical one-tail & 1.859548038 & \\
\hline $\mathrm{P}(\mathrm{T}<=\mathrm{t})$ two-tail & 0.291991238 & & $\mathrm{P}(\mathrm{T}<=\mathrm{t})$ two-tail & 0.575570278 & & $\mathrm{P}(\mathrm{T}<=\mathrm{t})$ two-tail & 0.716067454 & \\
\hline t Critical two-tail & 2.306004135 & & t Critical two-tail & 2.306004135 & & t Critical two-tail & 2.306004135 & \\
\hline Decision & cannot reject $\mathrm{H}$ & & Decision & cannot reject $\mathrm{H}$ & & Decision & cannot reject Ho & \\
\hline \multicolumn{9}{|c|}{ Wisconsin Method vs Provisional Cone test } \\
\hline $\mathrm{G}_{\mathrm{sb}}$ & & & \% Absorption & & & $\mathrm{G}_{\mathrm{sa}}$ & & \\
\hline \multicolumn{3}{|c|}{ t-Test: Two-Sample Assuming Equal Variances } & \multicolumn{3}{|c|}{ t-Test: Two-Sample Assuming Equal Variances } & \multicolumn{3}{|c|}{ t-Test: Two-Sample Assuming Equal Variances } \\
\hline & Variable 1 & Variable 2 & & Variable 1 & Variable 2 & & Variable 1 & Variable 2 \\
\hline Mean & 2.648191358 & 2.585670471 & Mean & 1.292328953 & 2.173440261 & Mean & 2.742027431 & 2.739632195 \\
\hline Variance & 3.10593E-05 & $2.51641 \mathrm{E}-05$ & Variance & 0.010630769 & 0.010261538 & Variance & $1.57444 \mathrm{E}-05$ & $2.94752 \mathrm{E}-05$ \\
\hline Observations & 5 & 5 & Observations & 5 & 5 & Observations & 5 & 5 \\
\hline Pooled Variance & 2.81117E-05 & & Pooled Variance & 0.010446153 & & Pooled Variance & $2.26098 \mathrm{E}-05$ & \\
\hline Hypothesized Mean & & & Hypothesized & & & Hypothesized Mean & & \\
\hline Difference & 0 & & Mean Difference & 0 & & Difference & 0 & \\
\hline df & 8 & & $d f$ & 8 & & $d f$ & 8 & \\
\hline t Stat & 18.64454577 & & t Stat & -13.63083881 & & t Stat & 0.796470852 & \\
\hline $\mathrm{P}(\mathrm{T}<=\mathrm{t})$ one-tail & $3.53341 \mathrm{E}-08$ & & $\mathrm{P}(\mathrm{T}<=\mathrm{t})$ one-tail & 4.03715E-07 & & $\mathrm{P}(\mathrm{T}<=\mathrm{t})$ one-tail & 0.224373328 & \\
\hline t Critical one-tail & 1.859548038 & & t Critical one-tail & 1.859548038 & & t Critical one-tail & 1.859548038 & \\
\hline $\mathrm{P}(\mathrm{T}<=\mathrm{t})$ two-tail & $7.06681 \mathrm{E}-08$ & & $\mathrm{P}(\mathrm{T}<=\mathrm{t})$ two-tail & $8.0743 \mathrm{E}-07$ & & $\mathrm{P}(\mathrm{T}<=\mathrm{t})$ two-tail & 0.448746655 & \\
\hline t Critical two-tail & 2.306004135 & & t Critical two-tail & 2.306004135 & & t Critical two-tail & 2.306004135 & \\
\hline Decision & reject Ho & & Decision & reject Ho & & Decision & cannot reject Ho & \\
\hline
\end{tabular}


Corelok Method vs Provisional Cone test

$\mathrm{G}_{\mathrm{sb}}$

t-Test: Two-Sample Assuming Equal Variances

\begin{tabular}{lrr} 
& Variable 1 & Variable 2 \\
\hline Mean & 2.5908 & 2.585670471 \\
Variance & $2.12 \mathrm{E}-05$ & $2.51641 \mathrm{E}-05$ \\
Observations & 5 & 5 \\
Pooled Variance & $2.3182 \mathrm{E}-05$ & \\
Hypothesized Mean & & \\
Difference & 0 & \\
df & 8 \\
$\mathrm{t}$ Stat & 1.684502777 \\
$\mathrm{P}(\mathrm{T}<=\mathrm{t})$ one-tail & 0.065288729 \\
$\mathrm{t}$ Critical one-tail & 1.859548038 \\
$\mathrm{P}(\mathrm{T}<=\mathrm{t})$ two-tail & 0.130577457 & \\
$\mathrm{t}$ Critical two-tail & 2.306004135 & \\
\hline
\end{tabular}

Decision

cannot reject $\mathrm{Ho}$
\% Absorption

t-Test: Two-Sample Assuming Equal Variances

\begin{tabular}{lrc} 
& Variable 1 & Variable 2 \\
\hline Mean & 2.118 & 2.173440261 \\
Variance & 0.0038265 & 0.010261538
\end{tabular}

Variance

Observations

Pooled Variance

5

Hypothesized

Mean Difference

df

t Stat

$\mathrm{P}(\mathrm{T}<=\mathrm{t})$ one-tail

t Critical one-tail

$\mathrm{P}(\mathrm{T}<=\mathrm{t})$ two-tail

t Critical two-tail

Decision

0

8

$-1.044443649$

0.163405023

1.859548038

0.326810045

2.306004135

cannot reject Ho
$\mathrm{G}_{\mathrm{sa}}$

t-Test: Two-Sample Assuming Equal Variances

\begin{tabular}{lrr}
\hline & Variable 1 & \multicolumn{1}{c}{ Variable 2 } \\
\hline Mean & 2.7412 & 2.739632195 \\
Variance & 0.0000022 & $2.94752 \mathrm{E}-05$ \\
Observations & 5 & 5
\end{tabular}

Pooled Variance $\quad 1.58376 \mathrm{E}-05$

Hypothesized Mean

Difference 0

df

t Stat $\quad 0.622898721$

$\mathrm{P}(\mathrm{T}<=\mathrm{t})$ one-tail $\quad 0.275345349$

$\mathrm{t}$ Critical one-tail $\quad 1.859548038$

$\mathrm{P}(\mathrm{T}<=\mathrm{t})$ two-tail $\quad 0.550690697$

$\mathrm{t}$ Critical two-tail $\quad 2.306004135$

Decision cannot reject Ho

lowa Method vs Provisional Cone Test

$\mathrm{G}_{\mathrm{sb}}$

t-Test: Two-Sample Assuming Equal Variances

\begin{tabular}{lcc}
\hline & Variable 1 & Variable 2 \\
\hline Mean & 2.613826503 & 2.585670471 \\
Variance & $1.45227 \mathrm{E}-05$ & $2.51641 \mathrm{E}-05$
\end{tabular}

Observations

Pooled Variance $\quad 1.98434 \mathrm{E}-05$

Hypothesized Mean

Difference

df

t Stat

9.993865163

$\mathrm{P}(\mathrm{T}<=\mathrm{t})$ one-tail

$4.26358 \mathrm{E}-06$
$\%$ Absorption

t-Test: Two-Sample Assuming Equal Variances

\begin{tabular}{lrr} 
& Variable 1 & Variable 2 \\
\hline Mean & 1.772296724 & 2.173440261 \\
Variance & 0.005646844 & 0.010261538 \\
Observations & 5 & 5 \\
Pooled Variance & 0.007954191 & \\
Hypothesized & 0 & \\
Mean Difference & 8 & \\
df & -7.111673361 & \\
t Stat & $5.04123 \mathrm{E}-05$ & \\
P(T<=t) one-tail &
\end{tabular}

$\mathrm{G}_{\mathrm{sa}}$

t-Test: Two-Sample Assuming Equal Variances

\begin{tabular}{lrr} 
& Variable 1 & Variable 2 \\
\hline Mean & 2.740790258 & 2.739632195 \\
Variance & $7.05002 \mathrm{E}-06$ & $2.94752 \mathrm{E}-05$ \\
Observations & 5 & 5 \\
Pooled Variance & $1.82626 \mathrm{E}-05$ & \\
Hypothesized Mean & & \\
Difference & 0 & \\
df & 8 & \\
t Stat & 0.428470417 & \\
$\mathrm{P}(\mathrm{T}<=\mathrm{t})$ one-tail & 0.339805811 &
\end{tabular}




\begin{tabular}{lllll}
$\mathrm{t}$ Critical one-tail & 1.859548038 & $\mathrm{t}$ Critical one-tail & 1.859548038 & $\mathrm{t}$ Critical one-tail \\
$\mathrm{P}(\mathrm{T}<=\mathrm{t})$ two-tail & $8.52716 \mathrm{E}-06$ & $\mathrm{P}(\mathrm{T}<=\mathrm{t})$ two-tail & 0.000100825 & $\mathrm{P}(\mathrm{T}<=\mathrm{t}) \mathrm{two}-\mathrm{tail}$ \\
$\mathrm{t}$ Critical two-tail & 2.306004135 & $\mathrm{t}$ Critical two-tail & 2.306004135 & $\mathrm{t}$ Critical two-tail \\
\cline { 1 - 3 } Decision & reject Ho & Decision & reject Ho & Decision
\end{tabular}

Texas Method vs Provisional Cone Test

t-Test: Two-Sample Assuming Equal Variances

\begin{tabular}{lrr}
\hline & Variable 1 & Variable 2 \\
\hline Mean & 2.64230855 & 2.585670471 \\
Variance & $1.53927 \mathrm{E}-05$ & $2.51641 \mathrm{E}-05$ \\
Observations & 5 & 5 \\
Pooled Variance & $2.02784 \mathrm{E}-05$ & \\
Hypothesized Mean & & \\
Difference & 0 \\
df & 8 \\
t Stat & 19.88665512 \\
P(T<=t) one-tail & $2.12999 \mathrm{E}-08$ \\
t Critical one-tail & 1.859548038 \\
$\mathrm{P}(\mathrm{T}<=\mathrm{t})$ two-tail & $4.25998 \mathrm{E}-08$ \\
$\mathrm{t}$ Critical two-tail & 2.306004135 \\
\hline Decision & reject Ho
\end{tabular}

California Test 225 vs Provisional Cone Test

$\mathrm{G}_{\mathrm{sb}}$

t-Test: Two-Sample Assuming Equal Variances

\begin{tabular}{lrr}
\hline & Variable 1 & \multicolumn{1}{c}{ Variable 2 } \\
\hline Mean & 2.595249707 & 2.585670471 \\
Variance & $4.34241 \mathrm{E}-05$ & $2.51641 \mathrm{E}-05$ \\
Observations & 5 & 5 \\
Pooled Variance & $3.42941 \mathrm{E}-05$ &
\end{tabular}

\% Absorption

t-Test: Two-Sample Assuming Equal Variances

\begin{tabular}{lrr} 
& Variable 1 & Variable 2 \\
\hline Mean & 1.485641157 & 2.173440261 \\
Variance & 0.008513207 & 0.010261538 \\
Observations & 5 & 5 \\
Pooled Variance & 0.009387373 & \\
Hypothesized & & \\
Mean Difference & 0 & \\
df & 8 &
\end{tabular}

t Stat

1.859548038

$\mathrm{P}(\mathrm{T}<=\mathrm{t})$ two-tail $\quad 3.56154 \mathrm{E}-06$

$\mathrm{t}$ Critical two-tail $\quad 2.306004135$

Decision

reject Ho
$\mathrm{G}_{\mathrm{sa}}$

t-Test: Two-Sample Assuming Equal Variances

\begin{tabular}{lrr}
\hline & Variable 1 & Variable 2 \\
\hline Mean & 2.740429693 & 2.739632195 \\
Variance & $9.39621 \mathrm{E}-06$ & $2.94752 \mathrm{E}-05$ \\
Observations & 5 & 5 \\
Pooled Variance & $1.94357 \mathrm{E}-05$ & \\
Hypothesized Mean & 0 \\
Difference & 8 \\
df & 0.286021871 \\
t Stat & 0.391064014 \\
$\mathrm{P}(\mathrm{T}<=\mathrm{t})$ one-tail & 1.859548038 \\
$\mathrm{t}$ Critical one-tail & 0.782128028 \\
$\mathrm{P}(\mathrm{T}<=\mathrm{t})$ two-tail & 2.306004135 \\
$\mathrm{t}$ Critical two-tail & cannot reject Ho
\end{tabular}

$\mathrm{G}_{\mathrm{sa}}$

t-Test: Two-Sample Assuming Equal Variances

t-Test: Two-Sample Assuming Equal Variances

\begin{tabular}{lrr}
\hline & Variable 1 & Variable 2 \\
\hline Mean & 2.047250137 & 2.173440261 \\
Variance & 0.00932495 & 0.010261538 \\
Observations & 5 & 5 \\
Pooled Variance & 0.009793244 &
\end{tabular}

\begin{tabular}{lrr} 
& Variable 1 & \multicolumn{1}{c}{ Variable 2 } \\
\hline Mean & 2.740861917 & 2.739632195 \\
Variance & $3.24632 \mathrm{E}-06$ & $2.94752 \mathrm{E}-05$ \\
Observations & 5 & 5 \\
Pooled Variance & $1.63607 \mathrm{E}-05$ &
\end{tabular}




\begin{tabular}{lr}
$\begin{array}{l}\text { Hypothesized Mean } \\
\text { Difference }\end{array}$ & 0 \\
df & 8 \\
t Stat & 2.586372741 \\
$P(T<=t)$ one-tail & 0.016147358 \\
t Critical one-tail & 1.859548038 \\
$P(T<=t)$ two-tail & 0.032294715 \\
t Critical two-tail & 2.306004135 \\
\hline Decision & reject Ho
\end{tabular}

Hypothesized

Mean Difference

df

t Stat

$\mathrm{P}(\mathrm{T}<=\mathrm{t})$ one-tail

t Critical one-tail

$\mathrm{P}(\mathrm{T}<=\mathrm{t})$ two-tail

t Critical two-tail

Decision

\% Absorption

t-Test: Two-Sample Assuming Equal Variances

t-Test: Two-Sample Assuming Equal Variances

\begin{tabular}{lrr}
\hline & Variable 1 & \multicolumn{1}{c}{ Variable 2 } \\
\hline Mean & 2.581988139 & 2.578801985 \\
Variance & $2.29539 \mathrm{E}-05$ & $2.43636 \mathrm{E}-05$ \\
Observations & 5 & 5
\end{tabular}

Pooled Variance $\quad 2.36587 \mathrm{E}-05$

Hypothesized Mean

Difference 0

df

\begin{tabular}{ll}
$\mathrm{t}$ Stat & 1.035716748 \\
$\mathrm{P}(\mathrm{T}<=\mathrm{t})$ one-tail & 0.165312116 \\
$\mathrm{t}$ Critical one-tail & 1.859548038 \\
$\mathrm{P}(\mathrm{T}<=\mathrm{t})$ two-tail & 0.330624232 \\
$\mathrm{t}$ Critical two-tail & 2.306004135 \\
\hline Decision & cannot reject Ho
\end{tabular}

Arizona DOT Method vs Provisional Surface test

$\mathrm{G}_{\mathrm{sb}}$

$\mathrm{t}$-Test: Two-Sample Assuming Equal Variances

\begin{tabular}{lrr} 
& Variable 1 & Variable 2 \\
\hline Mean & 2.230624229 & 2.309363834 \\
Variance & 0.004422822 & 0.004412621 \\
Observations & 5 & 5 \\
Pooled Variance & 0.004417722 & \\
Hypothesized & 0 & \\
Mean Difference & 8 \\
df & & \\
t Stat & -1.873113344 \\
P(T<=t) one-tail & 0.048968588 \\
t Critical one-tail & 1.859548038 \\
P(T<=t) two-tail & 0.097937176 \\
t Critical two-tail & 2.306004135 \\
\hline Decision & cannot reject Ho
\end{tabular}

Decision cannot reject Ho

\% Absorption

t-Test: Two-Sample Assuming Equal Variances

$\begin{array}{lc}\text { Hypothesized Mean } & 0 \\ \text { Difference } & 8 \\ \mathrm{df} & 0.480701382 \\ \mathrm{t} \text { Stat } & 0.321799667 \\ \mathrm{P}(\mathrm{T}<=\mathrm{t}) \text { one-tail } & 1.859548038 \\ \mathrm{t} \text { Critical one-tail } & 0.643599334 \\ \mathrm{P}(\mathrm{T}<=\mathrm{t}) \text { two-tail } & 2.306004135 \\ \mathrm{t} \text { Critical two-tail } & \text { cannot reject Ho }\end{array}$

$\mathrm{G}_{\mathrm{sa}}$

t-Test: Two-Sample Assuming Equal Variances

\begin{tabular}{lrr}
\hline & Variable 1 & Variable 2 \\
\hline Mean & 2.739779533 & 2.742098407 \\
Variance & $1.03461 \mathrm{E}-05$ & $6.36252 \mathrm{E}-06$ \\
Observations & 5 & 5 \\
Pooled Variance & $8.3543 \mathrm{E}-06$ & \\
Hypothesized Mean & & \\
Difference & 0 \\
df & 8 \\
t Stat & -1.268504898 \\
$\mathrm{P}(\mathrm{T}<=\mathrm{t})$ one-tail & 0.12014148 \\
$\mathrm{t}$ Critical one-tail & 1.859548038 \\
$\mathrm{P}(\mathrm{T}<=\mathrm{t})$ two-tail & 0.24028296 \\
$\mathrm{t}$ Critical two-tail & 2.306004135 & \\
\hline Decision & cannot reject Ho
\end{tabular}

$\mathrm{G}_{\mathrm{sa}}$

t-Test: Two-Sample Assuming Equal Variances 


\begin{tabular}{|c|c|c|}
\hline & Variable 1 & Variable 2 \\
\hline Mean & 2.589072123 & 2.578801985 \\
\hline Variance & $2.03027 \mathrm{E}-05$ & $2.43636 \mathrm{E}-05$ \\
\hline Observations & 5 & 5 \\
\hline Pooled Variance & $2.23331 \mathrm{E}-05$ & \\
\hline $\begin{array}{l}\text { Hypothesized Mea } \\
\text { Difference }\end{array}$ & 0 & \\
\hline df & 8 & \\
\hline t Stat & 3.436144364 & \\
\hline $\mathrm{P}(\mathrm{T}<=\mathrm{t})$ one-tail & 0.004437044 & \\
\hline t Critical one-tail & 1.859548038 & \\
\hline $\mathrm{P}(\mathrm{T}<=\mathrm{t})$ two-tail & 0.008874088 & \\
\hline t Critical two-tail & 2.306004135 & \\
\hline Decision & reject Ho & \\
\hline \multirow{2}{*}{\multicolumn{3}{|c|}{$\begin{array}{l}\text { Wisconsin Method vs Provisional Surface test } \\
\qquad G_{s b} \\
\text { t-Test: Two-Sample Assuming Equal Variances }\end{array}$}} \\
\hline & & \\
\hline & Variable 1 & Variable 2 \\
\hline Mean & 2.648191358 & 2.578801985 \\
\hline Variance & 3.10593E-05 & $2.43636 \mathrm{E}-05$ \\
\hline Observations & 5 & 5 \\
\hline Pooled Variance & 2.77114E-05 & \\
\hline $\begin{array}{l}\text { Hypothesized Mea } \\
\text { Difference }\end{array}$ & 0 & \\
\hline$d f$ & 8 & \\
\hline t Stat & 20.84172071 & \\
\hline $\mathrm{P}(\mathrm{T}<=\mathrm{t})$ one-tail & 1.47293E-08 & \\
\hline t Critical one-tail & 1.859548038 & \\
\hline $\mathrm{P}(\mathrm{T}<=\mathrm{t})$ two-tail & $2.94586 \mathrm{E}-08$ & \\
\hline t Critical two-tail & 2.306004135 & \\
\hline
\end{tabular}

\begin{tabular}{|c|c|c|}
\hline & Variable 1 & Variable 2 \\
\hline Mean & 2.136857453 & 2.309363834 \\
\hline Variance & 0.009385425 & 0.004412621 \\
\hline Observations & 5 & 5 \\
\hline Pooled Variance & 0.006899023 & \\
\hline $\begin{array}{l}\text { Hypothesized } \\
\text { Mean Difference }\end{array}$ & 0 & \\
\hline df & 8 & \\
\hline t Stat & -3.283835331 & \\
\hline $\mathrm{P}(\mathrm{T}<=\mathrm{t})$ one-tail & 0.005561962 & \\
\hline t Critical one-tail & 1.859548038 & \\
\hline $\mathrm{P}(\mathrm{T}<=\mathrm{t})$ two-tail & 0.011123923 & \\
\hline t Critical two-tail & 2.306004135 & \\
\hline Decision & ject Ho & \\
\hline
\end{tabular}

\begin{tabular}{lrr}
\hline & Variable 1 & Variable 2 \\
\hline Mean & 2.7406968 & 2.742098407 \\
Variance & $1.04231 \mathrm{E}-05$ & $6.36252 \mathrm{E}-06$ \\
Observations & 5 & 5 \\
Pooled Variance & $8.39281 \mathrm{E}-06$ \\
Hypothesized Mean & \\
Difference & 0 \\
df & 8 \\
t Stat & -0.764967128 \\
$\mathrm{P}(\mathrm{T}<=\mathrm{t})$ one-tail & 0.233127801 \\
$\mathrm{t}$ Critical one-tail & 1.859548038 \\
$\mathrm{P}(\mathrm{T}<=\mathrm{t})$ two-tail & 0.466255603 \\
$\mathrm{t}$ Critical two-tail & 2.306004135 \\
\hline Decision & cannot reject Ho \\
\end{tabular}

\% Absorption

t-Test: Two-Sample Assuming Equal Variances

\begin{tabular}{lrr}
\hline & Variable 1 & Variable 2 \\
\hline Mean & 1.292328953 & 2.309363834 \\
Variance & 0.010630769 & 0.004412621 \\
Observations & 5 & 5 \\
Pooled Variance & 0.007521695 & \\
Hypothesized & 0 & \\
Mean Difference & 8 & \\
df & & \\
t Stat & -18.54163365 & \\
$\mathrm{P}(\mathrm{T}<=\mathrm{t})$ one-tail & $3.69005 \mathrm{E}-08$ & \\
$\mathrm{t}$ Critical one-tail & 1.859548038 & \\
$\mathrm{P}(\mathrm{T}<=\mathrm{t})$ two-tail & $7.3801 \mathrm{E}-08$ & \\
$\mathrm{t}$ Critical two-tail & 2.306004135 & \\
\hline
\end{tabular}

$G_{\text {sa }}$

t-Test: Two-Sample Assuming Equal Variances

\begin{tabular}{lrr}
\hline & \multicolumn{1}{c}{ Variable 1 } & \multicolumn{1}{c}{ Variable 2 } \\
\hline Mean & 2.742027431 & 2.742098407 \\
Variance & $1.57444 \mathrm{E}-05$ & $6.36252 \mathrm{E}-06$ \\
Observations & 5 & 5 \\
Pooled Variance & $1.10535 \mathrm{E}-05$ & \\
Hypothesized Mean & & \\
Difference & 0 & \\
df & 8 & \\
$\mathrm{t}$ Stat & -0.033754541 & \\
$\mathrm{P}(\mathrm{T}<=\mathrm{t})$ one-tail & 0.48694994 & \\
$\mathrm{t}$ Critical one-tail & 1.859548038 & \\
$\mathrm{P}(\mathrm{T}<=\mathrm{t})$ two-tail & 0.97389988 & \\
$\mathrm{t}$ Critical two-tail & 2.306004135 & \\
\hline
\end{tabular}


Corelok Method vs Provisional Surface test

t-Test: Two-Sample Assuming Equal Variances

\begin{tabular}{lrr}
\hline & Variable 1 & Variable 2 \\
\hline Mean & 2.5908 & 2.578801985 \\
Variance & $2.12 \mathrm{E}-05$ & $2.43636 \mathrm{E}-05$ \\
Observations & 5 & 5 \\
Pooled Variance & $2.27818 \mathrm{E}-05$ & \\
Hypothesized Mean & & \\
Difference & 0 & \\
df & 8 & \\
t Stat & 3.974527817 & \\
$\mathrm{P}(\mathrm{T}<=\mathrm{t})$ one-tail & 0.002046455 & \\
$\mathrm{t}$ Critical one-tail & 1.859548038 & \\
$\mathrm{P}(\mathrm{T}<=\mathrm{t})$ two-tail & 0.00409291 & \\
$\mathrm{t}$ Critical two-tail & 2.306004135 & \\
\hline Decision & reject Ho
\end{tabular}

lowa Method vs Provisional Surface Test

t-Test: Two-Sample Assuming Equal Variances

\begin{tabular}{|c|c|c|}
\hline & Variable 1 & Variable 2 \\
\hline Mean & 2.613826503 & 2.578801985 \\
\hline Variance & $1.45227 \mathrm{E}-05$ & $2.43636 \mathrm{E}-05$ \\
\hline Observations & 5 & \\
\hline Pooled Variance & $1.94431 \mathrm{E}-05$ & \\
\hline $\begin{array}{l}\text { Hypothesized Mean } \\
\text { Difference }\end{array}$ & 0 & \\
\hline $\mathrm{df}$ & 8 & \\
\hline
\end{tabular}

\% Absorption

t-Test: Two-Sample Assuming Equal Variances

\begin{tabular}{lrr} 
& Variable 1 & Variable 2 \\
\hline Mean & 2.118 & 2.309363834 \\
Variance & 0.0038265 & 0.004412621 \\
Observations & 5 & 5 \\
Pooled Variance & 0.004119561 & \\
Hypothesized & 0 & \\
Mean Difference & 8 & \\
df & & \\
t Stat & -4.714161098 & \\
$\mathrm{P}(\mathrm{T}<=\mathrm{t})$ one-tail & 0.000756762 & \\
$\mathrm{t}$ Critical one-tail & 1.859548038 & \\
$\mathrm{P}(\mathrm{T}<=\mathrm{t})$ two-tail & 0.001513523 & \\
$\mathrm{t}$ Critical two-tail & 2.306004135 & \\
\hline Decision & reject Ho
\end{tabular}

\% Absorption

t-Test: Two-Sample Assuming Equal Variances

\begin{tabular}{lrr} 
& Variable 1 & Variable 2 \\
\hline Mean & 1.772296724 & 2.309363834 \\
Variance & 0.005646844 & 0.004412621 \\
Observations & 5 & 5 \\
Pooled Variance & 0.005029732 & \\
Hypothesized & & \\
Mean Difference & 0 & \\
df & 8 &
\end{tabular}

$\mathrm{G}_{\mathrm{sa}}$

t-Test: Two-Sample Assuming Equal Variances

\begin{tabular}{lrr}
\hline & Variable 1 & Variable 2 \\
\hline Mean & 2.7412 & 2.742098407 \\
Variance & 0.0000022 & $6.36252 \mathrm{E}-06$ \\
Observations & 5 & 5 \\
Pooled Variance & $4.28126 \mathrm{E}-06$ & \\
Hypothesized Mean & 0 & \\
Difference & 8 \\
df & -0.686526811 & \\
t Stat & 0.255892571 & \\
$\mathrm{P}(\mathrm{T}<=\mathrm{t})$ one-tail & 1.859548038 \\
$\mathrm{t}$ Critical one-tail & 0.511785142 \\
$\mathrm{P}(\mathrm{T}<=\mathrm{t})$ two-tail & 2.306004135 & \\
$\mathrm{t}$ Critical two-tail & cannot reject Ho
\end{tabular}

$\mathrm{G}_{\mathrm{sa}}$

t-Test: Two-Sample Assuming Equal Variances

\begin{tabular}{lrr}
\hline & Variable 1 & Variable 2 \\
\hline Mean & 2.740790258 & 2.742098407 \\
Variance & $7.05002 \mathrm{E}-06$ & $6.36252 \mathrm{E}-06$ \\
Observations & 5 & 5 \\
Pooled Variance & $6.70627 \mathrm{E}-06$ & \\
Hypothesized Mean & & \\
Difference & 0 & \\
df & 8 &
\end{tabular}




\begin{tabular}{lc}
$\mathrm{t}$ Stat & 12.55911201 \\
$\mathrm{P}(\mathrm{T}<=\mathrm{t})$ one-tail & $7.57064 \mathrm{E}-07$ \\
$\mathrm{t}$ Critical one-tail & 1.859548038 \\
$\mathrm{P}(\mathrm{T}<=\mathrm{t})$ two-tail & $1.51413 \mathrm{E}-06$ \\
$\mathrm{t}$ Critical two-tail & 2.306004135 \\
\hline
\end{tabular}

\begin{tabular}{lr}
$\mathrm{t}$ Stat & -11.9736379 \\
$\mathrm{P}(\mathrm{T}<=\mathrm{t})$ one-tail & $1.09005 \mathrm{E}-06$ \\
$\mathrm{t}$ Critical one-tail & 1.859548038 \\
$\mathrm{P}(\mathrm{T}<=\mathrm{t})$ two-tail & $2.1801 \mathrm{E}-06$ \\
$\mathrm{t}$ Critical two-tail & 2.306004135 \\
\hline Decision & reject Ho
\end{tabular}

\begin{tabular}{ll}
$\mathrm{t}$ Stat & -0.79870561 \\
$\mathrm{P}(\mathrm{T}<=\mathrm{t})$ one-tail & 0.223760881 \\
$\mathrm{t}$ Critical one-tail & 1.859548038 \\
$\mathrm{P}(\mathrm{T}<=\mathrm{t})$ two-tail & 0.447521762 \\
$\mathrm{t}$ Critical two-tail & 2.306004135 \\
\hline Decision & cannot reject Ho
\end{tabular}

Texas Method vs Provisional Surface Test

$\mathrm{G}_{\mathrm{sb}}$

t-Test: Two-Sample Assuming Equal Variances

\begin{tabular}{lrr}
\hline & Variable 1 & Variable 2 \\
\hline Mean & 2.64230855 & 2.578801985 \\
Variance & $1.53927 \mathrm{E}-05$ & $2.43636 \mathrm{E}-05$ \\
Observations & 5 & 5 \\
Pooled Variance & $1.98781 \mathrm{E}-05$ & \\
Hypothesized Mean & & \\
Difference & 0 & \\
df & 8 & \\
t Stat & 22.52167631 & \\
$\mathrm{P}(\mathrm{T}<=\mathrm{t})$ one-tail & $7.99673 \mathrm{E}-09$ & \\
$\mathrm{t}$ Critical one-tail & 1.859548038 \\
$\mathrm{P}(\mathrm{T}<=\mathrm{t})$ two-tail & $1.59935 \mathrm{E}-08$ \\
$\mathrm{t}$ Critical two-tail & 2.306004135 \\
\hline
\end{tabular}

Decision

reject Ho

California Test 225 vs Provisional Surface Test

$$
\mathrm{G}_{\mathrm{sb}}
$$

t-Test: Two-Sample Assuming Equal Variances

\begin{tabular}{lcc}
\hline & Variable 1 & Variable 2 \\
\hline Mean & 2.595249707 & 2.578801985 \\
Variance & $4.34241 \mathrm{E}-05$ & $2.43636 \mathrm{E}-05$
\end{tabular}

\section{\% Absorption}

t-Test: Two-Sample Assuming Equal Variances

\begin{tabular}{lrr} 
& Variable 1 & Variable 2 \\
\hline Mean & 1.485641157 & 2.309363834 \\
Variance & 0.008513207 & 0.004412621 \\
Observations & 5 & 5 \\
Pooled Variance & 0.006462914 & \\
Hypothesized & 0 & \\
Mean Difference & 8 \\
df & & \\
t Stat & -16.20081363 \\
P(T<=t) one-tail & $1.05911 E-07$ & \\
t Critical one-tail & 1.859548038 \\
$\mathrm{P}(\mathrm{T}<=\mathrm{t})$ two-tail & $2.11821 \mathrm{E}-07$ \\
$\mathrm{t}$ Critical two-tail & 2.306004135 & \\
\hline
\end{tabular}

Decision

reject $\mathrm{Ho}$

\section{\% Absorption}

t-Test: Two-Sample Assuming Equal Variances

\begin{tabular}{lrc} 
& Variable 1 & Variable 2 \\
\hline Mean & 2.047250137 & 2.309363834 \\
Variance & 0.00932495 & 0.004412621
\end{tabular}

$\mathrm{G}_{\mathrm{sa}}$

t-Test: Two-Sample Assuming Equal Variances

\begin{tabular}{lrr} 
& Variable 1 & Variable 2 \\
\hline Mean & 2.740429693 & 2.742098407 \\
Variance & $9.39621 \mathrm{E}-06$ & $6.36252 \mathrm{E}-06$ \\
Observations & 5 & 5 \\
Pooled Variance & $7.87936 \mathrm{E}-06$ & \\
Hypothesized Mean & 0 \\
Difference & 8 \\
df & -0.939953797 \\
$\mathrm{t}$ Stat & 0.187375634 \\
$\mathrm{P}(\mathrm{T}<=\mathrm{t})$ one-tail & 1.859548038 \\
$\mathrm{t}$ Critical one-tail & 0.374751268 \\
$\mathrm{P}(\mathrm{T}<=\mathrm{t})$ two-tail & 2.306004135 \\
$\mathrm{t}$ Critical two-tail & cannot reject Ho
\end{tabular}

$\mathrm{G}_{\mathrm{sa}}$

t-Test: Two-Sample Assuming Equal Variances

\begin{tabular}{lcc}
\multicolumn{3}{c}{ t-Test: Two-Sample Assuming Equal Variances } \\
\hline Mean & Variable 1 & Variable 2 \\
Variance & 2.740861917 & 2.742098407 \\
& $3.24632 \mathrm{E}-06$ & $6.36252 \mathrm{E}-06$
\end{tabular}




\begin{tabular}{|c|c|c|c|c|c|c|c|c|}
\hline Observations & 5 & 5 & Observations & 5 & 5 & Observations & 5 & 5 \\
\hline Pooled Variance & 3.38939E-05 & & Pooled Variance & 0.006868786 & & Pooled Variance & $4.80442 \mathrm{E}-06$ & \\
\hline Hypothesized Mean & & & Hypothesized & & & Hypothesized Mean & & \\
\hline Difference & 0 & & Mean Difference & 0 & & Difference & 0 & \\
\hline df & 8 & & df & 8 & & df & 8 & \\
\hline t Stat & 4.466992783 & & t Stat & -5.000572576 & & t Stat & -0.891949173 & \\
\hline $\mathrm{P}(\mathrm{T}<=\mathrm{t})$ one-tail & 0.001045779 & & $\mathrm{P}(\mathrm{T}<=\mathrm{t})$ one-tail & 0.000526037 & & $\mathrm{P}(\mathrm{T}<=\mathrm{t})$ one-tail & 0.199226665 & \\
\hline t Critical one-tail & 1.859548038 & & t Critical one-tail & 1.859548038 & & t Critical one-tail & 1.859548038 & \\
\hline $\mathrm{P}(\mathrm{T}<=\mathrm{t})$ two-tail & 0.002091559 & & $\mathrm{P}(\mathrm{T}<=\mathrm{t})$ two-tail & 0.001052073 & & $\mathrm{P}(\mathrm{T}<=\mathrm{t})$ two-tail & 0.39845333 & \\
\hline t Critical two-tail & 2.306004135 & & t Critical two-tail & 2.306004135 & & t Critical two-tail & 2.306004135 & \\
\hline Decision & reject Ho & & Decision & reject Ho & & Decision & cannot reject Ho & \\
\hline \multicolumn{9}{|c|}{ Arizona DOT Method vs Hard Paper Method } \\
\hline $\mathrm{G}_{\mathrm{sb}}$ & & & \% Absorption & & & $\mathrm{G}_{\mathrm{sa}}$ & & \\
\hline \multicolumn{3}{|c|}{ t-Test: Two-Sample Assuming Equal Variances } & \multicolumn{3}{|c|}{ t-Test: Two-Sample Assuming Equal Variances } & \multicolumn{3}{|c|}{ t-Test: Two-Sample Assuming Equal Variances } \\
\hline & Variable 1 & Variable 2 & & Variable 1 & Variable 2 & & Variable 1 & Variable 2 \\
\hline Mean & 2.589072123 & 2.581988139 & Mean & 2.136857453 & 2.230624229 & Mean & 2.7406968 & 2.739779533 \\
\hline Variance & 2.03027E-05 & $2.29539 E-05$ & Variance & 0.009385425 & 0.004422822 & Variance & $1.04231 \mathrm{E}-05$ & $1.03461 \mathrm{E}-05$ \\
\hline Observations & 5 & 5 & Observations & 5 & 5 & Observations & 5 & 5 \\
\hline Pooled Variance & $2.16283 \mathrm{E}-05$ & & Pooled Variance & 0.006904124 & & Pooled Variance & $1.03846 \mathrm{E}-05$ & \\
\hline Hypothesized Mean & & & Hypothesized & & & Hypothesized Mean & & \\
\hline Difference & 0 & & Mean Difference & 0 & & Difference & 0 & \\
\hline df & 8 & & $\mathrm{df}$ & 8 & & df & 8 & \\
\hline t Stat & 2.408442829 & & t Stat & -1.784286988 & & t Stat & 0.450060615 & \\
\hline $\mathrm{P}(\mathrm{T}<=\mathrm{t})$ one-tail & 0.021305806 & & $\mathrm{P}(\mathrm{T}<=\mathrm{t})$ one-tail & 0.056106989 & & $\mathrm{P}(\mathrm{T}<=\mathrm{t})$ one-tail & 0.332306085 & \\
\hline t Critical one-tail & 1.859548038 & & t Critical one-tail & 1.859548038 & & t Critical one-tail & 1.859548038 & \\
\hline $\mathrm{P}(\mathrm{T}<=\mathrm{t})$ two-tail & 0.042611612 & & $\mathrm{P}(\mathrm{T}<=\mathrm{t})$ two-tail & 0.112213978 & & $\mathrm{P}(\mathrm{T}<=\mathrm{t})$ two-tail & 0.664612169 & \\
\hline t Critical two-tail & 2.306004135 & & t Critical two-tail & 2.306004135 & & t Critical two-tail & 2.306004135 & \\
\hline Decision & reject Ho & & Decision & cannot reject $\mathrm{Hc}$ & & Decision & cannot reject Ho & \\
\hline
\end{tabular}

Wisconsin Method vs Hard Paper Method 
$\mathrm{G}_{\mathrm{sb}}$

t-Test: Two-Sample Assuming Equal Variances

\begin{tabular}{lrr}
\hline & Variable 1 & Variable 2 \\
\hline Mean & 2.648191358 & 2.581988139 \\
Variance & $3.10593 \mathrm{E}-05$ & $2.29539 \mathrm{E}-05$ \\
Observations & 5 & 5 \\
Pooled Variance & $2.70066 \mathrm{E}-05$ & \\
Hypothesized Mean & & \\
Difference & 0 & \\
df & 8 & \\
$\mathrm{t}$ Stat & 20.14254121 & \\
$\mathrm{P}(\mathrm{T}<=\mathrm{t})$ one-tail & $1.92637 \mathrm{E}-08$ & \\
$\mathrm{t}$ Critical one-tail & 1.859548038 & \\
$\mathrm{P}(\mathrm{T}<=\mathrm{t})$ two-tail & $3.85275 \mathrm{E}-08$ & \\
$\mathrm{t}$ Critical two-tail & 2.306004135 & \\
\hline
\end{tabular}

Decision

reject Ho

Corelok Method vs Hard Paper Method

$$
\mathrm{G}_{\mathrm{sb}}
$$

t-Test: Two-Sample Assuming Equal Variances

\begin{tabular}{lrr}
\hline & Variable 1 & Variable 2 \\
\hline Mean & 2.5908 & 2.581988139 \\
Variance & $2.12 \mathrm{E}-05$ & $2.29539 \mathrm{E}-05$ \\
Observations & 5 & 5 \\
Pooled Variance & $2.2077 \mathrm{E}-05$ & \\
Hypothesized Mean & & \\
Difference & 0 & \\
df & 8 & \\
t Stat & 2.965296402 & \\
P(T<=t) one-tail & 0.008999991 & \\
t Critical one-tail & 1.859548038 &
\end{tabular}

\% Absorption

t-Test: Two-Sample Assuming Equal Variances

\begin{tabular}{lcc} 
& Variable 1 & Variable 2 \\
\hline Mean & 1.292328953 & 2.230624229 \\
Variance & 0.010630769 & 0.004422822
\end{tabular}

Variance

Observations

Pooled Variance

.007526795

Hypothesized

Mean Difference

t Stat

$\mathrm{P}(\mathrm{T}<=\mathrm{t})$ one-tail

t Critical one-tail

$\mathrm{P}(\mathrm{T}<=\mathrm{t})$ two-tail

$\mathrm{t}$ Critical two-tail

Decision

-tail

reject $\mathrm{Ho}$

2.306004135

\% Absorption

t-Test: Two-Sample Assuming Equal Variances

\begin{tabular}{lrr} 
& Variable 1 & Variable 2 \\
\hline Mean & 2.118 & 2.230624229 \\
Variance & 0.0038265 & 0.004422822 \\
Observations & 5 & 5 \\
Pooled Variance & 0.004124661 & \\
Hypothesized & 0 & \\
Mean Difference & 8 & \\
df & & \\
t Stat & -2.772730733 & \\
P(T<=t) one-tail & 0.01209724 & \\
t Critical one-tail & 1.859548038 &
\end{tabular}

$\mathrm{G}_{\mathrm{sa}}$

t-Test: Two-Sample Assuming Equal Variances

\begin{tabular}{lrr}
\hline & Variable 1 & Variable 2 \\
\hline Mean & 2.742027431 & 2.739779533 \\
Variance & $1.57444 \mathrm{E}-05$ & $1.03461 \mathrm{E}-05$ \\
Observations & 5 & 5 \\
Pooled Variance & $1.30453 \mathrm{E}-05$ & \\
Hypothesized Mean & 0 & \\
Difference & 8 \\
$\mathrm{df}$ & 0.984057132 \\
$\mathrm{t}$ Stat & 0.17695443 \\
$\mathrm{P}(\mathrm{T}<=\mathrm{t})$ one-tail & 1.859548038 \\
$\mathrm{t}$ Critical one-tail & 0.35390886 \\
$\mathrm{P}(\mathrm{T}<=\mathrm{t})$ two-tail & 2.306004135 \\
$\mathrm{t}$ Critical two-tail & cannot reject Ho
\end{tabular}

$\mathrm{G}_{\mathrm{sa}}$

t-Test: Two-Sample Assuming Equal Variances

\begin{tabular}{lrr} 
& Variable 1 & Variable 2 \\
\hline Mean & 2.7412 & 2.739779533 \\
Variance & 0.0000022 & $1.03461 \mathrm{E}-05$ \\
Observations & 5 & 5 \\
Pooled Variance & & \\
Hypothesized Mean & $0.27304 \mathrm{E}-06$ & \\
Difference & & \\
df & 8 & \\
$\mathrm{t}$ Stat & 0.896730815 & \\
$\mathrm{P}(\mathrm{T}<=\mathrm{t})$ one-tail & 0.198022412 & \\
$\mathrm{t}$ Critical one-tail & 1.859548038 &
\end{tabular}




\begin{tabular}{ll}
$\mathrm{P}(\mathrm{T}<=\mathrm{t})$ two-tail & 0.017999982 \\
$\mathrm{t}$ Critical two-tail & 2.306004135 \\
\hline Decision & reject Ho
\end{tabular}

lowa Method vs Hard Paper Method

$\mathrm{G}_{\mathrm{sb}}$

t-Test: Two-Sample Assuming Equal Variances

\begin{tabular}{lrr}
\hline & Variable 1 & Variable 2 \\
\hline Mean & 2.613826503 & 2.581988139 \\
Variance & $1.45227 \mathrm{E}-05$ & $2.29539 \mathrm{E}-05$ \\
Observations & 5 & 5 \\
Pooled Variance & $1.87383 \mathrm{E}-05$ & \\
Hypothesized Mean & 0 \\
Difference & 8 \\
df & 11.6293528 \\
t Stat & $1.36097 \mathrm{E}-06$ \\
$\mathrm{P}(\mathrm{T}<=\mathrm{t})$ one-tail & 1.859548038 \\
$\mathrm{t}$ Critical one-tail & $2.72194 \mathrm{E}-06$ \\
$\mathrm{P}(\mathrm{T}<=\mathrm{t})$ two-tail & & \\
$\mathrm{t}$ Critical two-tail & 2.306004135 & \\
\hline Decision & reject Ho
\end{tabular}

Texas Method vs Hard Paper Method

$\mathrm{G}_{\mathrm{sb}}$

t-Test: Two-Sample Assuming Equal Variances

\begin{tabular}{lrr}
\hline & Variable 1 & \multicolumn{1}{c}{ Variable 2 } \\
\hline Mean & 2.64230855 & 2.581988139 \\
Variance & $1.53927 \mathrm{E}-05$ & $2.29539 \mathrm{E}-05$ \\
Observations & 5 & 5 \\
Pooled Variance & $1.91733 \mathrm{E}-05$ &
\end{tabular}

\begin{tabular}{ll}
$\mathrm{P}(\mathrm{T}<=\mathrm{t})$ two-tail & 0.024194479 \\
$\mathrm{t}$ Critical two-tail & 2.306004135 \\
\hline Decision & reject Ho
\end{tabular}

$\mathrm{P}(\mathrm{T}<=\mathrm{t})$ two-tail
$\mathrm{t}$ Critical two-tail
Decision

0.396044824

2.306004135

cannot reject Ho
\% Absorption

t-Test: Two-Sample Assuming Equal Variances

\begin{tabular}{lrr}
\hline & Variable 1 & Variable 2 \\
\hline Mean & 1.772296724 & 2.230624229 \\
Variance & 0.005646844 & 0.004422822 \\
Observations & 5 & 5 \\
Pooled Variance & 0.005034833 & \\
Hypothesized & & \\
Mean Difference & 0 & \\
df & 8 &
\end{tabular}

t Stat $\quad-10.21300139$

$\mathrm{P}(\mathrm{T}<=\mathrm{t})$ one-tail $\quad 3.62536 \mathrm{E}-06$

t Critical one-tail 1.859548038

$\mathrm{P}(\mathrm{T}<=\mathrm{t})$ two-tail $\quad 7.25072 \mathrm{E}-06$

$\mathrm{t}$ Critical two-tail $\quad 2.306004135$

Decision reject $\mathrm{Ho}$

$\%$ Absorption

t-Test: Two-Sample Assuming Equal Variances

\begin{tabular}{lrr}
\hline & Variable 1 & Variable 2 \\
\hline Mean & 1.485641157 & 2.230624229 \\
Variance & 0.008513207 & 0.004422822 \\
Observations & 5 & 5 \\
Pooled Variance & 0.006468015 &
\end{tabular}

$\mathrm{G}_{\mathrm{sa}}$

t-Test: Two-Sample Assuming Equal Variances

\begin{tabular}{lrr} 
& Variable 1 & Variable 2 \\
\hline Mean & 2.740790258 & 2.739779533 \\
Variance & $7.05002 \mathrm{E}-06$ & $1.03461 \mathrm{E}-05$ \\
Observations & 5 & 5 \\
Pooled Variance & $8.69805 \mathrm{E}-06$ & \\
Hypothesized Mean & 0 & \\
Difference & 8 \\
df & & \\
t Stat & 0.541866365 & \\
$\mathrm{P}(\mathrm{T}<=\mathrm{t})$ one-tail & 0.301335752 & \\
$\mathrm{t}$ Critical one-tail & 1.859548038 \\
$\mathrm{P}(\mathrm{T}<=\mathrm{t})$ two-tail & 0.602671504 \\
$\mathrm{t}$ Critical two-tail & 2.306004135 & \\
\hline Decision & cannot reject Ho
\end{tabular}

$\mathrm{G}_{\mathrm{sa}}$

t-Test: Two-Sample Assuming Equal Variances

\begin{tabular}{lrr}
\hline & \multicolumn{1}{c}{ Variable 1 } & \multicolumn{1}{c}{ Variable 2 } \\
\hline Mean & 2.740429693 & 2.739779533 \\
Variance & $9.39621 \mathrm{E}-06$ & $1.03461 \mathrm{E}-05$ \\
Observations & 5 & 5 \\
Pooled Variance & $9.87115 \mathrm{E}-06$ &
\end{tabular}




\begin{tabular}{lr} 
Hypothesized Mean & \\
Difference & 0 \\
df & 8 \\
t Stat & 21.7813979 \\
$\mathrm{P}(\mathrm{T}<=\mathrm{t})$ one-tail & $1.04077 \mathrm{E}-08$ \\
$\mathrm{t}$ Critical one-tail & 1.859548038 \\
$\mathrm{P}(\mathrm{T}<=\mathrm{t})$ two-tail & $2.08154 \mathrm{E}-08$ \\
$\mathrm{t}$ Critical two-tail & 2.306004135 \\
\hline Decision & reject Ho
\end{tabular}

Hypothesized

Mean Difference

df

t Stat

$\mathrm{P}(\mathrm{T}<=\mathrm{t})$ one-tail

$t$ Critical one-tail

$\mathrm{P}(\mathrm{T}<=\mathrm{t})$ two-tail

$\mathrm{t}$ Critical two-tail

Decision

$\%$ Absorption

t-Test: Two-Sample Assuming Equal Variances

t-Test: Two-Sample Assuming Equal Variances

\begin{tabular}{lrr} 
& Variable 1 & Variable 2 \\
\hline Mean & 2.595249707 & 2.581988139 \\
Variance & $4.34241 \mathrm{E}-05$ & $2.29539 \mathrm{E}-05$ \\
Observations & 5 & 5
\end{tabular}

Pooled Variance $\quad 3.3189 \mathrm{E}-05$

Hypothesized Mean

Difference 0

df

t Stat

$\mathrm{P}(\mathrm{T}<=\mathrm{t})$ one-tail

3.639717146

t Critical one-tail

0.003295831

$\mathrm{P}(\mathrm{T}<=\mathrm{t})$ two-tail

1.859548038

tCritical two-tail

0.006591661

Decision

reject Ho

\begin{tabular}{lrc} 
& Variable 1 & Variable 2 \\
\hline Mean & 2.047250137 & 2.230624229 \\
Variance & 0.00932495 & 0.004422822
\end{tabular}

$-14.64640041$

2.31781E-07

1.859548038

4.63562E-07

2.306004135

$\begin{array}{lll}\text { Variance } & 0.00932495 & 0.004422822\end{array}$

Observations

Pooled Variance $\quad 0.006873886$

Hypothesized

Mean Difference

df

\section{t Stat}

$\mathrm{P}(\mathrm{T}<=\mathrm{t})$ one-tail

0

$\mathrm{t}$ Critical one-tail

$-3.497089988$

$\mathrm{P}(\mathrm{T}<=\mathrm{t})$ two-tail $\quad 0.008113618$

\begin{tabular}{ll}
$\mathrm{t}$ Critical two-tail & 2.306004135 \\
\hline
\end{tabular}

Decision reject $\mathrm{Ho}$

Hypothesized Mean

Difference

0

df

t Stat

0.327194877

$\mathrm{P}(\mathrm{T}<=\mathrm{t})$ one-tail $\quad 0.375958888$

$\mathrm{t}$ Critical one-tail $\quad 1.859548038$

$\mathrm{P}(\mathrm{T}<=\mathrm{t})$ two-tail $\quad 0.751917776$

t Critical two-tail $\quad 2.306004135$

Decision cannot reject Ho

$\mathrm{G}_{\mathrm{sa}}$

t-Test: Two-Sample Assuming Equal Variances

\begin{tabular}{lrr} 
& Variable 1 & \multicolumn{1}{c}{ Variable 2 } \\
\hline Mean & 2.740861917 & 2.739779533 \\
Variance & $3.24632 \mathrm{E}-06$ & $1.03461 \mathrm{E}-05$ \\
Observations & 5 & 5
\end{tabular}

Pooled Variance 6.7962E-06

Hypothesized Mean

Difference 0

df

t Stat $\quad 0.656475386$

$\mathrm{P}(\mathrm{T}<=\mathrm{t})$ one-tail $\quad 0.264972227$

$\mathrm{t}$ Critical one-tail $\quad 1.859548038$

$\mathrm{P}(\mathrm{T}<=\mathrm{t})$ two-tail $\quad 0.529944454$

t Critical two-tail $\quad 2.306004135$

Decision cannot reject $\mathrm{Ho}$

$\mathrm{G}_{\mathrm{sa}}$

t-Test: Two-Sample Assuming Equal Variances

t-Test: Two-Sample Assuming Equal Variances 


\begin{tabular}{lrr}
\hline & Variable 1 & Variable 2 \\
\hline Mean & 2.648191358 & 2.589072123 \\
Variance & $3.10593 \mathrm{E}-05$ & $2.03027 \mathrm{E}-05$ \\
Observations & 5 & 5 \\
Pooled Variance & $2.5681 \mathrm{E}-05$ & \\
Hypothesized Mean & & \\
Difference & 0 & \\
df & 8 & \\
t Stat & 18.44560548 & \\
$\mathrm{P}(\mathrm{T}<=\mathrm{t})$ one-tail & $3.84328 \mathrm{E}-08$ & \\
$\mathrm{t}$ Critical one-tail & 1.859548038 & \\
$\mathrm{P}(\mathrm{T}<=\mathrm{t})$ two-tail & $7.68656 \mathrm{E}-08$ & \\
$\mathrm{t}$ Critical two-tail & 2.306004135 & \\
\hline
\end{tabular}

\begin{tabular}{lrr}
\hline & Variable 1 & Variable 2 \\
\hline Mean & 1.292328953 & 2.136857453 \\
Variance & 0.010630769 & 0.009385425 \\
Observations & 5 & 5 \\
Pooled Variance & 0.010008097 & \\
Hypothesized & & \\
Mean Difference & 0 & \\
df & 8 & \\
t Stat & -13.34776549 & \\
P(T<=t) one-tail & $4.74483 E-07$ & \\
t Critical one-tail & 1.859548038 & \\
P(T<=t) two-tail & $9.48967 \mathrm{E}-07$ & \\
t Critical two-tail & 2.306004135 & \\
\hline Decision & &
\end{tabular}

\begin{tabular}{lrr}
\hline & Variable 1 & Variable 2 \\
\hline Mean & 2.742027431 & 2.7406968 \\
Variance & $1.57444 \mathrm{E}-05$ & $1.04231 \mathrm{E}-05$ \\
Observations & 5 & 5 \\
Pooled Variance & $1.30838 \mathrm{E}-05$ \\
Hypothesized Mean & 0 \\
Difference & 8 \\
df & 0.581649578 \\
t Stat & 0.288410315 \\
$\mathrm{P}(\mathrm{T}<=\mathrm{t})$ one-tail & 1.859548038 \\
$\mathrm{t}$ Critical one-tail & 0.576820631 \\
$\mathrm{P}(\mathrm{T}<=\mathrm{t})$ two-tail & 2.306004135 \\
$\mathrm{t}$ Critical two-tail & cannot reject Ho \\
\hline Decision & &
\end{tabular}

Corelok Method vs Arizona DOT Method

$\mathrm{G}_{\mathrm{sb}}$

t-Test: Two-Sample Assuming Equal Variances

\begin{tabular}{lrr}
\hline & Variable 1 & Variable 2 \\
\hline Mean & 2.5908 & 2.589072123 \\
Variance & $2.12 \mathrm{E}-05$ & $2.03027 \mathrm{E}-05$ \\
Observations & 5 & 5 \\
Pooled Variance & $2.07514 \mathrm{E}-05$ & \\
Hypothesized Mean & & \\
Difference & 0 & \\
df & 8 & \\
$\mathrm{t}$ Stat & 0.599735292 & \\
$\mathrm{P}(\mathrm{T}<=\mathrm{t})$ one-tail & 0.282639005 & \\
$\mathrm{t}$ Critical one-tail & 1.859548038 & \\
$\mathrm{P}(\mathrm{T}<=\mathrm{t})$ two-tail & 0.56527801 & \\
$\mathrm{t}$ Critical two-tail & 2.306004135 & \\
\hline
\end{tabular}

\% Absorption

t-Test: Two-Sample Assuming Equal Variances

\begin{tabular}{lrr} 
& Variable 1 & Variable 2 \\
\hline Mean & 2.118 & 2.136857453 \\
Variance & 0.0038265 & 0.009385425 \\
Observations & 5 & 5 \\
Pooled Variance & 0.006605962 & \\
Hypothesized & 0 & \\
Mean Difference & 8 & \\
df & & \\
$t$ Stat & -0.366847019 & \\
$P(T<=t)$ one-tail & 0.361623343 & \\
$t$ Critical one-tail & 1.859548038 & \\
$P(T<=t)$ two-tail & 0.723246686 & \\
$t$ Critical two-tail & 2.306004135 & \\
\hline
\end{tabular}

$\mathrm{G}_{\mathrm{sa}}$

t-Test: Two-Sample Assuming Equal Variances

\begin{tabular}{lrr}
\hline & Variable 1 & \multicolumn{1}{c}{ Variable 2 } \\
\hline Mean & 2.7412 & 2.7406968 \\
Variance & 0.0000022 & $1.04231 \mathrm{E}-05$ \\
Observations & 5 & 5 \\
Pooled Variance & $6.31155 \mathrm{E}-06$ & \\
Hypothesized Mean & & \\
Difference & 0 & \\
df & 8 & \\
$\mathrm{t}$ Stat & 0.316696243 & \\
$\mathrm{P}(\mathrm{T}<=\mathrm{t})$ one-tail & 0.379790188 & \\
$\mathrm{t}$ Critical one-tail & 1.859548038 & \\
$\mathrm{P}(\mathrm{T}<=\mathrm{t})$ two-tail & 0.759580376 & \\
$\mathrm{t}$ Critical two-tail & 2.306004135 & \\
\hline
\end{tabular}


lowa Method vs Arizona DOT Method

t-Test: Two-Sample Assuming Equal Variances

\begin{tabular}{lrr}
\hline & Variable 1 & \multicolumn{1}{c}{ Variable 2 } \\
\hline Mean & 2.613826503 & 2.589072123 \\
Variance & $1.45227 \mathrm{E}-05$ & $2.03027 \mathrm{E}-05$ \\
Observations & 5 & 5 \\
Pooled Variance & $1.74127 \mathrm{E}-05$ & \\
Hypothesized Mean & & \\
Difference & 0 & \\
df & 8 & \\
t Stat & 9.379697277 & \\
P(T<=t) one-tail & $6.83136 \mathrm{E}-06$ & \\
t Critical one-tail & 1.859548038 & \\
P(T<=t) two-tail & $1.36627 \mathrm{E}-05$ & \\
t Critical two-tail & 2.306004135 & \\
\hline Decision & reject Ho
\end{tabular}

Texas Method vs Arizona DOT Method

$\mathrm{G}_{\mathrm{sb}}$

t-Test: Two-Sample Assuming Equal Variances

\begin{tabular}{lrr}
\hline & Variable 1 & \multicolumn{1}{c}{ Variable 2 } \\
\hline Mean & 2.64230855 & 2.589072123 \\
Variance & $1.53927 \mathrm{E}-05$ & $2.03027 \mathrm{E}-05$ \\
Observations & 5 & 5 \\
$\begin{array}{l}\text { Pooled Variance } \\
\text { Hypothesized Mean }\end{array}$ & $1.78477 \mathrm{E}-05$ & \\
Difference & & \\
df & 0 &
\end{tabular}

\% Absorption

t-Test: Two-Sample Assuming Equal Variances

\begin{tabular}{lrr} 
& Variable 1 & Variable 2 \\
\hline Mean & 1.772296724 & 2.136857453 \\
Variance & 0.005646844 & 0.009385425 \\
Observations & 5 & 5 \\
Pooled Variance & 0.007516134 & \\
Hypothesized & 0 & \\
Mean Difference & 8 & \\
df & & \\
t Stat & -6.648790132 & \\
P(T<=t) one-tail & $8.05046 \mathrm{E}-05$ & \\
t Critical one-tail & 1.859548038 & \\
P(T<=t) two-tail & 0.000161009 & \\
t Critical two-tail & 2.306004135 & \\
\hline Decision & reject Ho
\end{tabular}

\% Absorption

t-Test: Two-Sample Assuming Equal Variances

\begin{tabular}{lrr} 
& Variable 1 & Variable 2 \\
\hline Mean & 1.485641157 & 2.136857453 \\
Variance & 0.008513207 & 0.009385425 \\
Observations & 5 & 5 \\
Pooled Variance & 0.008949316 & \\
Hypothesized & & \\
Mean Difference & 0 & \\
df & 8 &
\end{tabular}

$\mathrm{G}_{\mathrm{sa}}$

t-Test: Two-Sample Assuming Equal Variances

\begin{tabular}{lrr}
\hline & Variable 1 & \multicolumn{1}{c}{ Variable 2 } \\
\hline Mean & 2.740790258 & 2.7406968 \\
Variance & $7.05002 \mathrm{E}-06$ & $1.04231 \mathrm{E}-05$ \\
Observations & 5 & 5 \\
Pooled Variance & $8.73656 \mathrm{E}-06$ & \\
Hypothesized Mean & 0 & \\
Difference & 8 \\
df & 0.049994107 & \\
t Stat & 0.480676383 & \\
$\mathrm{P}(\mathrm{T}<=\mathrm{t})$ one-tail & 1.859548038 \\
$\mathrm{t}$ Critical one-tail & 0.961352766 \\
$\mathrm{P}(\mathrm{T}<=\mathrm{t})$ two-tail & 2.306004135 \\
$\mathrm{t}$ Critical two-tail & cannot reject Ho
\end{tabular}

$\mathrm{G}_{\mathrm{sa}}$

t-Test: Two-Sample Assuming Equal Variances

\begin{tabular}{lrr}
\hline & Variable 1 & \multicolumn{1}{c}{ Variable 2 } \\
\hline Mean & 2.740429693 & 2.7406968 \\
Variance & $9.39621 \mathrm{E}-06$ & $1.04231 \mathrm{E}-05$ \\
Observations & 5 & 5 \\
Pooled Variance & $9.90965 \mathrm{E}-06$ & \\
Hypothesized Mean & & \\
Difference & 0 & \\
df & 8 &
\end{tabular}




\begin{tabular}{lr}
$\mathrm{t}$ Stat & 19.92450749 \\
$\mathrm{P}(\mathrm{T}<=\mathrm{t})$ one-tail & $2.0984 \mathrm{E}-08$ \\
$\mathrm{t}$ Critical one-tail & 1.859548038 \\
$\mathrm{P}(\mathrm{T}<=\mathrm{t})$ two-tail & $4.1968 \mathrm{E}-08$ \\
$\mathrm{t}$ Critical two-tail & 2.306004135 \\
\hline
\end{tabular}

Decision

reject Ho

\begin{tabular}{lr} 
t Stat & -10.88429587 \\
$\mathrm{P}(\mathrm{T}<=\mathrm{t})$ one-tail & $2.24679 \mathrm{E}-06$ \\
$\mathrm{t}$ Critical one-tail & 1.859548038 \\
$\mathrm{P}(\mathrm{T}<=\mathrm{t})$ two-tail & $4.49358 \mathrm{E}-06$ \\
$\mathrm{t}$ Critical two-tail & 2.306004135 \\
\hline Decision & reject Ho
\end{tabular}

California Test 225 vs Arizona DOT Method

$$
\mathrm{G}_{\mathrm{sb}}
$$

t-Test: Two-Sample Assuming Equal Variances

\begin{tabular}{lrr}
\hline & Variable 1 & Variable 2 \\
\hline Mean & 2.595249707 & 2.589072123 \\
Variance & $4.34241 \mathrm{E}-05$ & $2.03027 \mathrm{E}-05$ \\
Observations & 5 & 5 \\
Pooled Variance & $3.18634 \mathrm{E}-05$ & \\
Hypothesized Mean & & \\
Difference & 0 \\
df & 8 \\
t Stat & 1.730383623 \\
P(T<=t) one-tail & 0.060905455 \\
t Critical one-tail & 1.859548038 \\
P(T<=t) two-tail & 0.12181091 \\
t Critical two-tail & 2.306004135 \\
\hline
\end{tabular}

Decision cannot reject Ho

Corelok Method vs Wisconsin Method

$$
\mathrm{G}_{\mathrm{sb}}
$$

t-Test: Two-Sample Assuming Equal Variances

\begin{tabular}{lrc}
\hline & Variable 1 & \multicolumn{1}{c}{ Variable 2 } \\
\hline Mean & 2.5908 & 2.648191358 \\
Variance & $2.12 \mathrm{E}-05$ & $3.10593 \mathrm{E}-05$
\end{tabular}

$\%$ Absorption

t-Test: Two-Sample Assuming Equal Variances

\begin{tabular}{lrr} 
& Variable 1 & Variable 2 \\
\hline Mean & 2.047250137 & 2.136857453 \\
Variance & 0.00932495 & 0.009385425 \\
Observations & 5 & 5 \\
Pooled Variance & 0.009355188 & \\
Hypothesized & & \\
Mean Difference & 0 & \\
df & 8 &
\end{tabular}

$\mathrm{t}$ Stat -1.464830001

$\mathrm{P}(\mathrm{T}<=\mathrm{t})$ one-tail $\quad 0.090564592$

t Critical one-tail $\quad 1.859548038$

$\mathrm{P}(\mathrm{T}<=\mathrm{t})$ two-tail $\quad 0.181129184$

$\mathrm{t}$ Critical two-tail $\quad 2.306004135$

Decision

cannot reject $\mathrm{Ho}$

\section{\% Absorption}

t-Test: Two-Sample Assuming Equal Variances

\begin{tabular}{lrc}
\hline & Variable 1 & Variable 2 \\
\hline Mean & 2.118 & 1.292328953 \\
Variance & 0.0038265 & 0.010630769
\end{tabular}

\begin{tabular}{ll}
$\mathrm{t}$ Stat & -0.134160879 \\
$\mathrm{P}(\mathrm{T}<=\mathrm{t})$ one-tail & 0.448294558 \\
$\mathrm{t}$ Critical one-tail & 1.859548038 \\
$\mathrm{P}(\mathrm{T}<=\mathrm{t})$ two-tail & 0.896589116 \\
$\mathrm{t}$ Critical two-tail & 2.306004135 \\
\hline Decision & cannot reject Ho
\end{tabular}

$\mathrm{G}_{\text {sa }}$

t-Test: Two-Sample Assuming Equal Variances

\begin{tabular}{lrr} 
& Variable 1 & \multicolumn{1}{c}{ Variable 2 } \\
\hline Mean & 2.740861917 & 2.7406968 \\
Variance & $3.24632 \mathrm{E}-06$ & $1.04231 \mathrm{E}-05$ \\
Observations & 5 & 5 \\
Pooled Variance & $6.83471 \mathrm{E}-06$ & \\
Hypothesized Mean & 0 \\
Difference & 8 \\
$\mathrm{df}$ & 0.099862774 \\
$\mathrm{t}$ Stat & 0.461455223 \\
$\mathrm{P}(\mathrm{T}<=\mathrm{t})$ one-tail & 1.859548038 \\
$\mathrm{t}$ Critical one-tail & 0.922910445 \\
$\mathrm{P}(\mathrm{T}<=\mathrm{t})$ two-tail & 2.306004135 \\
$\mathrm{t}$ Critical two-tail & cannot reject Ho
\end{tabular}

$\mathrm{G}_{\mathrm{sa}}$

t-Test: Two-Sample Assuming Equal Variances

\begin{tabular}{lrc}
\multicolumn{3}{c}{ t-Test: Two-Sample Assuming Equal Variances } \\
\hline Mean & Variable 1 & \multicolumn{1}{c}{ Variable 2 } \\
Variance & 2.7412 & 2.742027431 \\
& 0.0000022 & $1.57444 \mathrm{E}-05$
\end{tabular}




\begin{tabular}{|c|c|c|c|c|c|c|c|c|}
\hline Observations & 5 & 5 & Observations & 5 & 5 & Observations & 5 & 5 \\
\hline Pooled Variance & 2.61296E-05 & & Pooled Variance & 0.007228634 & & Pooled Variance & $8.97222 \mathrm{E}-06$ & \\
\hline Hypothesized Mean & & & Hypothesized & & & Hypothesized Mean & & \\
\hline Difference & 0 & & Mean Difference & 0 & & Difference & 0 & \\
\hline df & 8 & & df & 8 & & df & 8 & \\
\hline t Stat & 17.75210337 & & t Stat & 15.35496864 & & t Stat & -0.436769222 & \\
\hline $\mathrm{P}(\mathrm{T}<=\mathrm{t})$ one-tail & $5.18785 \mathrm{E}-08$ & & $\mathrm{P}(\mathrm{T}<=\mathrm{t})$ one-tail & $1.60699 \mathrm{E}-07$ & & $\mathrm{P}(\mathrm{T}<=\mathrm{t})$ one-tail & 0.336913847 & \\
\hline t Critical one-tail & 1.859548038 & & t Critical one-tail & 1.859548038 & & t Critical one-tail & 1.859548038 & \\
\hline$P(T<=t)$ two-tail & $1.03757 \mathrm{E}-07$ & & $\mathrm{P}(\mathrm{T}<=\mathrm{t})$ two-tail & $3.21398 \mathrm{E}-07$ & & $\mathrm{P}(\mathrm{T}<=\mathrm{t})$ two-tail & 0.673827694 & \\
\hline t Critical two-tail & 2.306004135 & & t Critical two-tail & 2.306004135 & & t Critical two-tail & 2.306004135 & \\
\hline Decision & reject Ho & & Decision & reject Ho & & Decision & cannot reject Ho & \\
\hline \multicolumn{9}{|c|}{ lowa Method vs Wisconsin Method } \\
\hline \multirow{2}{*}{\multicolumn{3}{|c|}{$\begin{array}{c}\mathrm{G}_{\mathrm{sb}} \\
\mathrm{t} \text {-Test: Two-Sample Assuming Equal Variances }\end{array}$}} & \multirow{2}{*}{\multicolumn{3}{|c|}{$\begin{array}{l}\text { \% Absorption } \\
\text { t-Test: Two-Sample Assuming Equal Variances }\end{array}$}} & \multirow{2}{*}{\multicolumn{3}{|c|}{$\begin{array}{l}\mathrm{G}_{\mathrm{sa}} \\
\mathrm{t} \text {-Test: Two-Sample Assuming Equal Variances }\end{array}$}} \\
\hline & & & & & & & & \\
\hline & Variable 1 & Variable 2 & & Variable 1 & Variable 2 & & Variable 1 & Variable 2 \\
\hline Mean & 2.613826503 & 2.648191358 & Mean & 1.772296724 & 1.292328953 & Mean & 2.740790258 & 2.742027431 \\
\hline Variance & 1.45227E-05 & 3.10593E-05 & Variance & 0.005646844 & 0.010630769 & Variance & $7.05002 \mathrm{E}-06$ & $1.57444 \mathrm{E}-05$ \\
\hline Observations & 5 & 5 & Observations & 5 & 5 & Observations & 5 & 5 \\
\hline Pooled Variance & $2.2791 \mathrm{E}-05$ & & Pooled Variance & 0.008138806 & & Pooled Variance & $1.13972 \mathrm{E}-05$ & \\
\hline $\begin{array}{l}\text { Hypothesized Mean } \\
\text { Difference }\end{array}$ & 0 & & $\begin{array}{l}\text { Hypothesized } \\
\text { Mean Difference }\end{array}$ & 0 & & $\begin{array}{l}\text { Hypothesized Mean } \\
\text { Difference }\end{array}$ & 0 & \\
\hline df & 8 & & $d f$ & 8 & & $\mathrm{df}$ & 8 & \\
\hline t Stat & 11.38158815 & & t Stat & 8.41204776 & & t Stat & -0.579429804 & \\
\hline $\mathrm{P}(\mathrm{T}<=\mathrm{t})$ one-tail & $1.60261 \mathrm{E}-06$ & & $\mathrm{P}(\mathrm{T}<=\mathrm{t})$ one-tail & $1.51832 \mathrm{E}-05$ & & $\mathrm{P}(\mathrm{T}<=\mathrm{t})$ one-tail & 0.289123228 & \\
\hline t Critical one-tail & 1.859548038 & & t Critical one-tail & 1.859548038 & & t Critical one-tail & 1.859548038 & \\
\hline $\mathrm{P}(\mathrm{T}<=\mathrm{t})$ two-tail & $3.20522 \mathrm{E}-06$ & & $\mathrm{P}(\mathrm{T}<=\mathrm{t})$ two-tail & 3.03665E-05 & & $\mathrm{P}(\mathrm{T}<=\mathrm{t})$ two-tail & 0.578246456 & \\
\hline t Critical two-tail & 2.306004135 & & t Critical two-tail & 2.306004135 & & t Critical two-tail & 2.306004135 & \\
\hline Decision & reject Ho & & Decision & reject Ho & & Decision & cannot reject Ho & \\
\hline
\end{tabular}


$\mathrm{G}_{\mathrm{sb}}$

t-Test: Two-Sample Assuming Equal Variances

\begin{tabular}{lrr} 
& Variable 1 & Variable 2 \\
\hline Mean & 2.64230855 & 2.648191358 \\
Variance & $1.53927 \mathrm{E}-05$ & $3.10593 \mathrm{E}-05$ \\
Observations & 5 & 5 \\
Pooled Variance & $2.3226 \mathrm{E}-05$ & \\
Hypothesized Mean & & \\
Difference & 0 \\
df & - \\
$\mathrm{t}$ Stat & 1.930045436 \\
$\mathrm{P}(\mathrm{T}<=\mathrm{t})$ one-tail & 0.044857186 \\
$\mathrm{t}$ Critical one-tail & 1.859548038 \\
$\mathrm{P}(\mathrm{T}<=\mathrm{t})$ two-tail & 0.089714373 \\
$\mathrm{t}$ Critical two-tail & 2.306004135 \\
\hline Decision & &
\end{tabular}

Decision

cannot reject Ho

California Test 225 vs Wisconsin Method

t-Test: Two-Sample Assuming Equal Variances

\begin{tabular}{lrr}
\hline & Variable 1 & Variable 2 \\
\hline Mean & 2.595249707 & 2.648191358 \\
Variance & $4.34241 \mathrm{E}-05$ & $3.10593 \mathrm{E}-05$ \\
Observations & 5 & 5 \\
Pooled Variance & $3.72417 \mathrm{E}-05$ & \\
Hypothesized Mean & & \\
Difference & 0 & \\
df & 8 & - \\
t Stat & 13.71679572 & \\
P(T<=t) one-tail & $3.84628 \mathrm{E}-07$ & \\
t Critical one-tail & 1.859548038 &
\end{tabular}

$\%$ Absorption

t-Test: Two-Sample Assuming Equal Variances

\begin{tabular}{lcc} 
& Variable 1 & Variable 2 \\
\hline Mean & 1.485641157 & 1.292328953 \\
Variance & 0.008513207 & 0.010630769
\end{tabular}

Variance

Observations

Pooled Variance

0.009571988

Hypothesized

Mean Difference

df

\section{t Stat}

$\mathrm{P}(\mathrm{T}<=\mathrm{t})$ one-tail

0.007070139

t Critical one-tail

1.859548038

$\mathrm{P}(\mathrm{T}<=\mathrm{t})$ two-tail

0.014140278

t Critical two-tail

Decision

2.306004135

\section{\% Absorption}

t-Test: Two-Sample Assuming Equal Variances

\begin{tabular}{lrr}
\hline & Variable 1 & Variable 2 \\
\hline Mean & 2.047250137 & 1.292328953 \\
Variance & 0.00932495 & 0.010630769 \\
Observations & 5 & 5 \\
Pooled Variance & 0.009977859 & \\
Hypothesized & 0 & \\
Mean Difference & 8 & \\
df & & \\
t Stat & 11.94958781 & \\
P(T<=t) one-tail & $1.10687 \mathrm{E}-06$ & \\
t Critical one-tail & 1.859548038 &
\end{tabular}

$\mathrm{G}_{\mathrm{sa}}$

t-Test: Two-Sample Assuming Equal Variance

\begin{tabular}{lrr}
\hline & Variable 1 & Variable 2 \\
\hline Mean & 2.740429693 & 2.742027431 \\
Variance & $9.39621 \mathrm{E}-06$ & $1.57444 \mathrm{E}-05$ \\
Observations & 5 & 5 \\
Pooled Variance & $1.25703 \mathrm{E}-05$ & \\
Hypothesized Mean & 0 \\
Difference & 8 \\
df & \\
t Stat & -0.712528952 \\
$\mathrm{P}(\mathrm{T}<=\mathrm{t})$ one-tail & 0.248195068 \\
$\mathrm{t}$ Critical one-tail & 1.859548038 \\
$\mathrm{P}(\mathrm{T}<=\mathrm{t})$ two-tail & 0.496390136 \\
$\mathrm{t}$ Critical two-tail & 2.306004135 \\
\hline Decision & cannot reject Ho
\end{tabular}

$\mathrm{G}_{\mathrm{sa}}$

t-Test: Two-Sample Assuming Equal Variances

\begin{tabular}{lrr}
\hline & Variable 1 & \multicolumn{1}{c}{ Variable 2 } \\
\hline Mean & 2.740861917 & 2.742027431 \\
Variance & $3.24632 \mathrm{E}-06$ & $1.57444 \mathrm{E}-05$ \\
Observations & 5 & 5 \\
Pooled Variance & $9.49538 \mathrm{E}-06$ & \\
Hypothesized Mean & & \\
Difference & 0 & \\
df & 8 &
\end{tabular}

t Stat

$-0.598041493$

$\mathrm{P}(\mathrm{T}<=\mathrm{t})$ one-tail $\quad 0.283176684$

t Critical one-tail $\quad 1.859548038$ 


\begin{tabular}{ll}
$\mathrm{P}(\mathrm{T}<=\mathrm{t})$ two-tail & $7.69257 \mathrm{E}-07$ \\
$\mathrm{t}$ Critical two-tail & 2.306004135 \\
\hline Decision & reject Ho
\end{tabular}

lowa Method vs CoreLok Method

t-Test: Two-Sample Assuming Equal Variances

\begin{tabular}{lrr}
\hline & Variable 1 & Variable 2 \\
\hline Mean & 2.613826503 & 2.5908 \\
Variance & $1.45227 \mathrm{E}-05$ & $2.12 \mathrm{E}-05$ \\
Observations & 5 & 5 \\
Pooled Variance & $1.78614 \mathrm{E}-05$ & \\
Hypothesized Mean & & \\
Difference & 0 & \\
df & 8 & \\
$\mathrm{t}$ Stat & 8.61471146 & \\
$\mathrm{P}(\mathrm{T}<=\mathrm{t})$ one-tail & $1.27663 \mathrm{E}-05$ & \\
$\mathrm{t}$ Critical one-tail & 1.859548038 \\
$\mathrm{P}(\mathrm{T}<=\mathrm{t})$ two-tail & $2.55327 \mathrm{E}-05$ \\
$\mathrm{t}$ Critical two-tail & 2.306004135 \\
\hline Decision & reject Ho
\end{tabular}

$\mathrm{G}_{\mathrm{sb}}$

t-Test: Two-Sample Assuming Equal Variances

\begin{tabular}{lrr}
\hline & Variable 1 & Variable 2 \\
\hline Mean & 2.64230855 & 2.5908 \\
Variance & $1.53927 \mathrm{E}-05$ & $2.12 \mathrm{E}-05$ \\
Observations & 5 & 5 \\
Pooled Variance & $1.82964 \mathrm{E}-05$ &
\end{tabular}

\begin{tabular}{ll}
$\mathrm{P}(\mathrm{T}<=\mathrm{t})$ two-tail & $2.21375 \mathrm{E}-06$ \\
$\mathrm{t}$ Critical two-tail & 2.306004135 \\
\hline Decision & reject Ho
\end{tabular}

$\mathrm{P}(\mathrm{T}<=\mathrm{t})$ two-tail
$\mathrm{t}$ Critical two-tail
Decision

0.566353368

cannot reject Ho
\% Absorption

t-Test: Two-Sample Assuming Equal Variances

\begin{tabular}{lrr}
\hline & Variable 1 & Variable 2 \\
\hline Mean & 1.772296724 & 2.118 \\
Variance & 0.005646844 & 0.0038265 \\
Observations & 5 & 5 \\
Pooled Variance & 0.004736672 & \\
Hypothesized & 0 & \\
Mean Difference & 8 & \\
df & & \\
t Stat & -7.942127449 & \\
$\mathrm{P}(\mathrm{T}<=\mathrm{t})$ one-tail & $2.30047 \mathrm{E}-05$ & \\
$\mathrm{t}$ Critical one-tail & 1.859548038 \\
$\mathrm{P}(\mathrm{T}<=\mathrm{t})$ two-tail & $4.60094 \mathrm{E}-05$ \\
$\mathrm{t}$ Critical two-tail & 2.306004135 \\
\hline Decision & reject Ho
\end{tabular}

$\mathrm{G}_{\mathrm{sa}}$

t-Test: Two-Sample Assuming Equal Variances

\begin{tabular}{lrr}
\hline & Variable 1 & Variable 2 \\
\hline Mean & 2.740790258 & 2.7412 \\
Variance & $7.05002 \mathrm{E}-06$ & 0.0000022 \\
Observations & 5 & 5 \\
Pooled Variance & $4.62501 \mathrm{E}-06$ & \\
Hypothesized Mean & 0 & \\
Difference & 8 \\
df & -0.301247819 \\
t Stat & 0.385453497 \\
$\mathrm{P}(\mathrm{T}<=\mathrm{t})$ one-tail & 1.859548038 \\
$\mathrm{t}$ Critical one-tail & 0.770906993 \\
$\mathrm{P}(\mathrm{T}<=\mathrm{t})$ two-tail & 2.306004135 \\
$\mathrm{t}$ Critical two-tail & cannot reject Ho
\end{tabular}

\% Absorption

t-Test: Two-Sample Assuming Equal Variances

\begin{tabular}{lrr}
\hline & Variable 1 & \multicolumn{1}{c}{ Variable 2 } \\
\hline Mean & 1.485641157 & 2.118 \\
Variance & 0.008513207 & 0.0038265 \\
Observations & 5 & 5 \\
Pooled Variance & 0.006169854 &
\end{tabular}

$\mathrm{G}_{\mathrm{sa}}$

t-Test: Two-Sample Assuming Equal Variances

\begin{tabular}{lrr}
\hline & \multicolumn{1}{c}{ Variable 1 } & \multicolumn{1}{c}{ Variable 2 } \\
\hline Mean & 2.740429693 & 2.7412 \\
Variance & $9.39621 \mathrm{E}-06$ & 0.0000022 \\
Observations & 5 & 5 \\
Pooled Variance & $5.7981 \mathrm{E}-06$ &
\end{tabular}




\begin{tabular}{lr}
$\begin{array}{l}\text { Hypothesized Mean } \\
\text { Difference }\end{array}$ & 0 \\
df & 8 \\
t Stat & 19.04000152 \\
$\mathrm{P}(\mathrm{T}<=\mathrm{t})$ one-tail & $2.99722 \mathrm{E}-08$ \\
$\mathrm{t}$ Critical one-tail & 1.859548038 \\
$\mathrm{P}(\mathrm{T}<=\mathrm{t})$ two-tail & $5.99445 \mathrm{E}-08$ \\
$\mathrm{t}$ Critical two-tail & 2.306004135 \\
\hline Decision & reject Ho
\end{tabular}

Hypothesized

Mean Difference

df

t Stat

$\mathrm{P}(\mathrm{T}<=\mathrm{t})$ one-tail

t Critical one-tail

$\mathrm{P}(\mathrm{T}<=\mathrm{t})$ two-tail

t Critical two-tail

Decision

$\%$ Absorption

t-Test: Two-Sample Assuming Equal Variances

t-Test: Two-Sample Assuming Equal Variances

\begin{tabular}{lrr}
\hline & Variable 1 & \multicolumn{1}{c}{ Variable 2 } \\
\hline Mean & 2.595249707 & 2.5908 \\
Variance & $4.34241 \mathrm{E}-05$ & $2.12 \mathrm{E}-05$ \\
Observations & 5 & 5
\end{tabular}

$\begin{array}{lr}\text { Observations } & 5 \\ \text { Pooled Variance } & 3.23121 \mathrm{E}-05 \\ \text { Hypothesized Mean } & \\ \text { Difference } & 8 \\ \mathrm{df} & 1.237710234 \\ \mathrm{t} \text { Stat } & 0.125457736 \\ \mathrm{P}(\mathrm{T}<=\mathrm{t}) \text { one-tail } & 1.859548038 \\ \mathrm{t} \text { Critical one-tail } & 0.250915472 \\ \mathrm{P}(\mathrm{T}<=\mathrm{t}) \text { two-tail } & 2.306004135 \\ \mathrm{t} \text { Critical two-tail } & \text { cannot reject Ho }\end{array}$

Texas Method vs lowa Method

$\mathrm{G}_{\mathrm{sb}}$

$\mathrm{t}$-Test: Two-Sample Assuming Equal Variances

\begin{tabular}{lrr} 
& Variable 1 & Variable 2 \\
\hline Mean & 2.047250137 & 2.118 \\
Variance & 0.00932495 & 0.0038265 \\
Observations & 5 & 5 \\
Pooled Variance & 0.006575725 & \\
Hypothesized & 0 & \\
Mean Difference & 8 & \\
df & & \\
t Stat & -1.379506601 & \\
P(T<=t) one-tail & 0.102534364 & \\
t Critical one-tail & 1.859548038 \\
P(T<=t) two-tail & 0.205068728 \\
t Critical two-tail & 2.306004135 \\
\hline Decision & & \\
\hline
\end{tabular}

Decision cannot reject Ho

\% Absorption

t-Test: Two-Sample Assuming Equal Variances

$\begin{array}{lc}\text { Hypothesized Mean } & \\ \text { Difference } & 8 \\ \mathrm{df} & -0.5058142 \\ \mathrm{t} \text { Stat } & 0.313313544 \\ \mathrm{P}(\mathrm{T}<=\mathrm{t}) \text { one-tail } & 1.859548038 \\ \mathrm{t} \text { Critical one-tail } & 0.626627088 \\ \mathrm{P}(\mathrm{T}<=\mathrm{t}) \text { two-tail } & 2.306004135 \\ \mathrm{t} \text { Critical two-tail } & \text { cannot reject Ho }\end{array}$

$\mathrm{G}_{\mathrm{sa}}$

t-Test: Two-Sample Assuming Equal Variances

\begin{tabular}{lrr}
\hline & Variable 1 & Variable 2 \\
\hline Mean & 2.740861917 & 2.7412 \\
Variance & $3.24632 \mathrm{E}-06$ & 0.0000022 \\
Observations & 5 & 5
\end{tabular}

Pooled Variance $\quad 2.72316 \mathrm{E}-06$

Hypothesized Mean

Difference 0

df 8

t Stat $\quad-0.323933791$

$\mathrm{P}(\mathrm{T}<=\mathrm{t})$ one-tail $\quad 0.377147424$

$\mathrm{t}$ Critical one-tail $\quad 1.859548038$

$\mathrm{P}(\mathrm{T}<=\mathrm{t})$ two-tail $\quad 0.754294848$

t Critical two-tail $\quad 2.306004135$

Decision cannot reject Ho

$\mathrm{G}_{\mathrm{sa}}$

t-Test: Two-Sample Assuming Equal Variances 


\begin{tabular}{|c|c|c|}
\hline & Variable 1 & Variable 2 \\
\hline Mean & 2.64230855 & 2.613826503 \\
\hline Variance & 1.53927E-05 & 1.45227E-05 \\
\hline Observations & 5 & 5 \\
\hline Pooled Variance & 1.49577E-05 & \\
\hline $\begin{array}{l}\text { Hypothesized Mea } \\
\text { Difference }\end{array}$ & 0 & \\
\hline $\mathrm{df}$ & 8 & \\
\hline t Stat & 11.64416927 & \\
\hline $\mathrm{P}(\mathrm{T}<=\mathrm{t})$ one-tail & 1.34787E-06 & \\
\hline t Critical one-tail & 1.859548038 & \\
\hline $\mathrm{P}(\mathrm{T}<=\mathrm{t})$ two-tail & 2.69573E-06 & \\
\hline t Critical two-tail & 2.306004135 & \\
\hline Decision & reject Ho & \\
\hline \multicolumn{3}{|c|}{ California Test 225 vs lowa Method } \\
\hline \multicolumn{3}{|c|}{ t-Test: Two-Sample Assuming Equal Variances } \\
\hline & Variable 1 & Variable 2 \\
\hline Mean & 2.595249707 & 2.613826503 \\
\hline Variance & $4.34241 \mathrm{E}-05$ & 1.45227E-05 \\
\hline Observations & 5 & 5 \\
\hline Pooled Variance & $2.89734 \mathrm{E}-05$ & \\
\hline $\begin{array}{l}\text { Hypothesized Mea } \\
\text { Difference }\end{array}$ & 0 & \\
\hline $\mathrm{df}$ & $\begin{array}{l}8 \\
-\end{array}$ & \\
\hline t Stat & 5.456835128 & \\
\hline $\mathrm{P}(\mathrm{T}<=\mathrm{t})$ one-tail & 0.000301896 & \\
\hline t Critical one-tail & 1.859548038 & \\
\hline $\mathrm{P}(\mathrm{T}<=\mathrm{t})$ two-tail & 0.000603792 & \\
\hline t Critical two-tail & 2.306004135 & \\
\hline
\end{tabular}

\begin{tabular}{lrr}
\hline & Variable 1 & Variable 2 \\
\hline Mean & 1.485641157 & 1.772296724 \\
Variance & 0.008513207 & 0.005646844 \\
Observations & 5 & 5 \\
Pooled Variance & 0.007080026 & \\
Hypothesized & 0 & \\
Mean Difference & 8 & \\
df & & \\
t Stat & -5.386578237 & \\
P(T<=t) one-tail & 0.000328227 & \\
t Critical one-tail & 1.859548038 & \\
P(T<=t) two-tail & 0.000656454 & \\
$t$ Critical two-tail & 2.306004135 & \\
\hline
\end{tabular}

\begin{tabular}{lrr}
\hline & Variable 1 & Variable 2 \\
\hline Mean & 2.740429693 & 2.740790258 \\
Variance & $9.39621 \mathrm{E}-06$ & $7.05002 \mathrm{E}-06$ \\
Observations & 5 & 5 \\
Pooled Variance & $8.22311 \mathrm{E}-06$ \\
Hypothesized Mean & 0 \\
Difference & 8 \\
df & \\
t Stat & -0.198808975 \\
$\mathrm{P}(\mathrm{T}<=\mathrm{t})$ one-tail & 0.423685902 \\
$\mathrm{t}$ Critical one-tail & 1.859548038 \\
$\mathrm{P}(\mathrm{T}<=\mathrm{t})$ two-tail & 0.847371804 \\
$\mathrm{t}$ Critical two-tail & 2.306004135 \\
\hline Decision & cannot reject Ho
\end{tabular}

\% Absorption

$\mathrm{G}_{\mathrm{sa}}$

t-Test: Two-Sample Assuming Equal Variances

\begin{tabular}{lrr}
\hline & Variable 1 & Variable 2 \\
\hline Mean & 2.047250137 & 1.772296724 \\
Variance & 0.00932495 & 0.005646844 \\
Observations & 5 & 5 \\
Pooled Variance & 0.007485897 & \\
Hypothesized & 0 & \\
Mean Difference & 8 & \\
df & & \\
t Stat & 5.024665958 & \\
P(T<=t) one-tail & 0.000510462 & \\
$t$ Critical one-tail & 1.859548038 & \\
P(T<=t) two-tail & 0.001020924 & \\
$t$ Critical two-tail & 2.306004135 & \\
\hline
\end{tabular}

t-Test: Two-Sample Assuming Equal Variances

\begin{tabular}{lrr}
\hline & \multicolumn{1}{c}{ Variable 1 } & \multicolumn{1}{c}{ Variable 2 } \\
\hline Mean & 2.740861917 & 2.740790258 \\
Variance & $3.24632 \mathrm{E}-06$ & $7.05002 \mathrm{E}-06$ \\
Observations & 5 & 5 \\
Pooled Variance & $5.14817 \mathrm{E}-06$ & \\
Hypothesized Mean & & \\
Difference & 0 & \\
df & 8 &
\end{tabular}

t Stat

$\mathrm{P}(\mathrm{T}<=\mathrm{t})$ one-tail $\quad 0.480698753$

$\mathrm{t}$ Critical one-tail $\quad 1.859548038$

$\mathrm{P}(\mathrm{T}<=\mathrm{t})$ two-tail $\quad 0.961397506$

$\mathrm{t}$ Critical two-tail $\quad 2.306004135$ 
California test 225 vs Texas Method
t-Test: Two-Sample Assuming Equal Variances

\begin{tabular}{lrr}
\hline & Variable 1 & Variable 2 \\
\hline Mean & 2.595249707 & 2.64230855 \\
Variance & $4.34241 \mathrm{E}-05$ & $1.53927 \mathrm{E}-05$ \\
Observations & 5 & 5 \\
Pooled Variance & $2.94084 \mathrm{E}-05$ & \\
Hypothesized Mean & & \\
Difference & 0 & \\
df & - & \\
& & \\
$\mathrm{t}$ Stat & 13.72066922 & \\
$\mathrm{P}(\mathrm{T}<=\mathrm{t})$ one-tail & $3.83792 \mathrm{E}-07$ & \\
$\mathrm{t}$ Critical one-tail & 1.859548038 & \\
$\mathrm{P}(\mathrm{T}<=\mathrm{t})$ two-tail & $7.67585 \mathrm{E}-07$ & \\
$\mathrm{t}$ Critical two-tail & 2.306004135 & \\
\hline
\end{tabular}

Decision reject Ho
\% Absorption

t-Test: Two-Sample Assuming Equal Variances

\begin{tabular}{lrr} 
& Variable 1 & Variable 2 \\
\hline Mean & 2.047250137 & 1.485641157 \\
Variance & 0.00932495 & 0.008513207 \\
Observations & 5 & 5 \\
Pooled Variance & 0.008919079 & \\
Hypothesized & 0 & \\
Mean Difference & 8 & \\
df & & \\
t Stat & 9.402515192 & \\
$\mathrm{P}(\mathrm{T}<=\mathrm{t})$ one-tail & $6.70963 \mathrm{E}-06$ & \\
$\mathrm{t}$ Critical one-tail & 1.859548038 & \\
$\mathrm{P}(\mathrm{T}<=\mathrm{t})$ two-tail & $1.34193 \mathrm{E}-05$ & \\
$\mathrm{t}$ Critical two-tail & 2.306004135 & \\
\hline
\end{tabular}

$\mathrm{G}_{\mathrm{sa}}$

t-Test: Two-Sample Assuming Equal Variances

\begin{tabular}{lrr} 
& Variable 1 & \multicolumn{1}{c}{ Variable 2 } \\
\hline Mean & 2.740861917 & 2.740429693 \\
Variance & $3.24632 \mathrm{E}-06$ & $9.39621 \mathrm{E}-06$ \\
Observations & 5 & 5 \\
Pooled Variance & $6.32126 \mathrm{E}-06$ & \\
Hypothesized Mean & & \\
Difference & 0 & \\
df & 8 &
\end{tabular}

t Stat $\quad 0.271817596$

$\mathrm{P}(\mathrm{T}<=\mathrm{t})$ one-tail $\quad 0.396322678$

$\mathrm{t}$ Critical one-tail $\quad 1.859548038$

$\mathrm{P}(\mathrm{T}<=\mathrm{t})$ two-tail $\quad 0.792645356$

$\mathrm{t}$ Critical two-tail $\quad 2.306004135$

Decision

cannot reject $\mathrm{Ho}$

\section{Coarse Aggregates}

\# 8 Regular aggregates

$\mathrm{G}_{\mathrm{sb}}$

t-Test: Two-Sample Assuming Equal Variances

\begin{tabular}{lrr}
\hline & Variable 1 & Variable 2 \\
\hline Mean & 2.641746231 & 2.6468 \\
Variance & $1.57526 \mathrm{E}-06$ & $8.7 \mathrm{E}-06$ \\
Observations & 5 & 5 \\
Pooled Variance & $5.13763 \mathrm{E}-06$ &
\end{tabular}

$\mathrm{G}_{\mathrm{sa}}$

\begin{tabular}{lrr}
\multicolumn{3}{c}{$\mathrm{t}$-Test: Two-Sample Assuming Equal Variances } \\
\hline Variable 1 & Variable 2 \\
\hline Mean & 2.693241561 & 2.67 \\
Variance & $4.73495 \mathrm{E}-06$ & $1 \mathrm{E}-06$ \\
Observations & 5 & 5 \\
Pooled Variance & $2.86747 \mathrm{E}-06$ &
\end{tabular}

$\%$ Absorption

t-Test: Two-Sample Assuming Equal Variances

\begin{tabular}{lrr}
\hline & Variable 1 & Variable 2 \\
\hline Mean & 0.723758884 & 0.3406 \\
Variance & 0.000463984 & 0.0007283 \\
Observations & 5 & 5 \\
Pooled Variance & 0.000596142 &
\end{tabular}




$\begin{array}{lr}\text { Hypothesized Mean } & 0 \\ \text { Difference } & 8 \\ \text { df } & - \\ & 3.525364608 \\ \text { t Stat } & 0.00389229 \\ \mathrm{P}(\mathrm{T}<=\mathrm{t}) \text { one-tail } & 1.859548038 \\ \mathrm{t} \text { Critical one-tail } & 0.00778458 \\ \mathrm{P}(\mathrm{T}<=\mathrm{t}) \text { two-tail } & 2.306004135 \\ \mathrm{t} \text { Critical two-tail } & \end{array}$

Decision reject Ho

\section{\# 8 Skid aggregates}

$\mathrm{G}_{\mathrm{sb}}$

t-Test: Two-Sample Assuming Equal Variances

\begin{tabular}{lrr}
\hline & Variable 1 & Variable 2 \\
\hline Mean & 2.645862664 & 2.6486 \\
Variance & $3.08352 \mathrm{E}-06$ & $1.3 \mathrm{E}-06$ \\
Observations & 5 & 5 \\
Pooled Variance & $2.19176 \mathrm{E}-06$ & \\
Hypothesized Mean & 0 & \\
Difference & 8 & \\
df & - & \\
& & \\
$\mathrm{t}$ Stat & & \\
$\mathrm{P}(\mathrm{T}<=\mathrm{t})$ one-tail & 0.923491116 & \\
$\mathrm{t}$ Critical one-tail & 1.859548038 & \\
$\mathrm{P}(\mathrm{T}<=\mathrm{t})$ two-tail & 0.019188412 & \\
$\mathrm{t}$ Critical two-tail & 2.306004135 & \\
\hline
\end{tabular}

Decision

reject Ho

\section{\# 9 aggregates}

$\mathrm{G}_{\mathrm{sb}}$

t-Test: Two-Sample Assuming Equal Variances

Variable 1 Variable 2
Hypothesized Mean

Difference

0

df

t Stat

$\mathrm{P}(\mathrm{T}<=\mathrm{t})$ one-tail

t Critical one-tail

$\mathrm{P}(\mathrm{T}<=\mathrm{t})$ two-tail

1.859548038

$\mathrm{t}$ Critical two-tail

Decision

reject Ho

$\mathrm{G}_{\mathrm{sa}}$

t-Test: Two-Sample Assuming Equal Variances

\begin{tabular}{lrr} 
& Variable 1 & Variable 2 \\
\hline Mean & 2.699293712 & 2.6686 \\
Variance & $7.81037 \mathrm{E}-06$ & $3 \mathrm{E}-07$ \\
Observations & 5 & 5
\end{tabular}

Pooled Variance 4.05518E-06

Hypothesized Mean

Difference

df

t Stat

$\mathrm{P}(\mathrm{T}<=\mathrm{t})$ one-tail

$\mathrm{t}$ Critical one-tail

$\mathrm{P}(\mathrm{T}<=\mathrm{t})$ two-tail

$\mathrm{t}$ Critical two-tail

Decision

$\mathrm{G}_{\mathrm{sa}}$

t-Test: Two-Sample Assuming Equal Variances

Variable 1

Variable 2
Hypothesized Mean

Difference

df

\section{t Stat}

24.81270268

$\mathrm{P}(\mathrm{T}<=\mathrm{t})$ one-tail

$3.72056 \mathrm{E}-09$

t Critical one-tail

1.859548038

$\mathrm{P}(\mathrm{T}<=\mathrm{t})$ two-tail

7.44112E-09

$\mathrm{t}$ Critical two-tail

2.306004135

Decision

reject Ho

\% Absorption

t-Test: Two-Sample Assuming Equal Variances

\begin{tabular}{lrr}
\hline & Variable 1 & Variable 2 \\
\hline Mean & 0.748110123 & 0.2822 \\
Variance & 0.000425298 & 0.0002587 \\
Observations & 5 & 5
\end{tabular}

Pooled Variance $\quad 0.000341999$

Hypothesized Mean

Difference

0

df

t Stat

39.83453699

$\mathrm{P}(\mathrm{T}<=\mathrm{t})$ one-tail

8.67455E-11

t Critical one-tail

1.859548038

$\mathrm{P}(\mathrm{T}<=\mathrm{t})$ two-tail

$1.73491 \mathrm{E}-10$

$\mathrm{t}$ Critical two-tail $\quad 2.306004135$

Decision

reject Ho

\% Absorption

t-Test: Two-Sample Assuming Equal Variances

Variable 


\begin{tabular}{|c|c|c|c|c|c|c|c|c|}
\hline Mean & 2.629621599 & 2.6468 & Mean & 2.683276078 & 2.6662 & Mean & 0.760401584 & 0.2744 \\
\hline Variance & 5.06589E-06 & 8.7E-06 & Variance & 7.22896E-06 & 7E-07 & Variance & 0.001050475 & 0.0017008 \\
\hline Observations & 5 & 5 & Observations & 5 & 5 & Observations & 5 & 5 \\
\hline $\begin{array}{l}\text { Pooled Variance } \\
\text { Hypothesized Mean }\end{array}$ & $6.88295 \mathrm{E}-06$ & & $\begin{array}{l}\text { Pooled Variance } \\
\text { Hypothesized Mean }\end{array}$ & $3.96448 \mathrm{E}-06$ & & $\begin{array}{l}\text { Pooled Variance } \\
\text { Hypothesized Mean }\end{array}$ & 0.001375637 & \\
\hline Difference & 0 & & Difference & 0 & & Difference & 0 & \\
\hline df & 8 & & $\mathrm{df}$ & 8 & & df & 8 & \\
\hline t Stat & 10.35298416 & & t Stat & 13.56016711 & & t Stat & 20.71837517 & \\
\hline $\mathrm{P}(\mathrm{T}<=\mathrm{t})$ one-tail & $3.2738 \mathrm{E}-06$ & & $\mathrm{P}(\mathrm{T}<=\mathrm{t})$ one-tail & 4.20204E-07 & & $\mathrm{P}(\mathrm{T}<=\mathrm{t})$ one-tail & $1.54336 \mathrm{E}-08$ & \\
\hline t Critical one-tail & 1.859548038 & & t Critical one-tail & 1.859548038 & & t Critical one-tail & 1.859548038 & \\
\hline $\mathrm{P}(\mathrm{T}<=\mathrm{t})$ two-tail & $6.5476 \mathrm{E}-06$ & & $\mathrm{P}(\mathrm{T}<=\mathrm{t})$ two-tail & 8.40409E-07 & & $\mathrm{P}(\mathrm{T}<=\mathrm{t})$ two-tail & $3.08672 \mathrm{E}-08$ & \\
\hline t Critical two-tail & 2.306004135 & & t Critical two-tail & 2.306004135 & & t Critical two-tail & 2.306004135 & \\
\hline Decision & reject Ho & & Decision & reject Ho & & Decision & reject Ho & \\
\hline \multicolumn{9}{|l|}{ \# 67 aggregates } \\
\hline $\mathrm{G}_{\mathrm{sb}}$ & & & $\mathrm{G}_{\mathrm{sa}}$ & & & \% Absorption & & \\
\hline \multicolumn{3}{|c|}{ t-Test: Two-Sample Assuming Equal Variances } & \multicolumn{3}{|c|}{ t-Test: Two-Sample Assuming Equal Variances } & \multicolumn{3}{|c|}{ t-Test: Two-Sample Assuming Equal Variances } \\
\hline & Variable 1 & Variable 2 & & Variable 1 & Variable 2 & & Variable 1 & Variable 2 \\
\hline Mean & 2.646465808 & 2.6534 & Mean & 2.695633545 & 2.672 & Mean & 0.689218918 & 0.2592 \\
\hline Variance & 3.32183E-06 & $8 \mathrm{E}-07$ & Variance & $1.91001 \mathrm{E}-06$ & $5 \mathrm{E}-07$ & Variance & 0.000439648 & 0.0003412 \\
\hline Observations & 5 & 5 & Observations & 5 & 5 & Observations & 5 & 5 \\
\hline $\begin{array}{l}\text { Pooled Variance } \\
\text { Hypothesized Mean }\end{array}$ & 2.06092E-06 & & $\begin{array}{l}\text { Pooled Variance } \\
\text { Hypothesized Mean }\end{array}$ & $1.20501 \mathrm{E}-06$ & & $\begin{array}{l}\text { Pooled Variance } \\
\text { Hypothesized Mean }\end{array}$ & 0.000390424 & \\
\hline Difference & 0 & & Difference & 0 & & Difference & 0 & \\
\hline df & 8 & & $\mathrm{df}$ & 8 & & $d f$ & 8 & \\
\hline t Stat & 7.637224835 & & t Stat & 34.04114824 & & t Stat & 34.41035785 & \\
\hline $\mathrm{P}(\mathrm{T}<=\mathrm{t})$ one-tail & $3.04461 \mathrm{E}-05$ & & $\mathrm{P}(\mathrm{T}<=\mathrm{t})$ one-tail & $3.02968 \mathrm{E}-10$ & & $\mathrm{P}(\mathrm{T}<=\mathrm{t})$ one-tail & $2.78065 \mathrm{E}-10$ & \\
\hline t Critical one-tail & 1.859548038 & & t Critical one-tail & 1.859548038 & & t Critical one-tail & 1.859548038 & \\
\hline $\mathrm{P}(\mathrm{T}<=\mathrm{t})$ two-tail & $6.08921 \mathrm{E}-05$ & & $\mathrm{P}(\mathrm{T}<=\mathrm{t})$ two-tail & 6.05937E-10 & & $\mathrm{P}(\mathrm{T}<=\mathrm{t})$ two-tail & $5.5613 \mathrm{E}-10$ & \\
\hline t Critical two-tail & 2.306004135 & & t Critical two-tail & 2.306004135 & & t Critical two-tail & 2.306004135 & \\
\hline Decision & reject Ho & & Decision & reject Ho & & Decision & reject Ho & \\
\hline
\end{tabular}

